\title{
DENDROLOGIA, ANATOMIA DO LENHO E "STATUS" DE CONSERVAÇÃO DAS ESPÉCIES LENHOSAS DOS GÊNEROS Cinchona, Croton e Uncaria NO ESTADO DO ACRE, BRASIL
}

Percy Amilcar Zevallos Pollito

Tese apresentada à Escola Superior de Agricultura "Luiz de Queiroz", Universidade de São Paulo, para obtenção do título de Doutor em Recursos Florestais, com opção em Silvicultura e Manejo Florestal..

P I R A C I C A B A

Estado de São Paulo - Brasil

Março - 2004 


\title{
DENDROLOGIA, ANATOMIA DO LENHO E "STATUS" DE CONSERVAÇÃO DAS ESPÉCIES LENHOSAS DOS GÊNEROS Cinchona, Croton e Uncaria NO ESTADO DO ACRE, BRASIL
}

\section{Percy Amilcar Zevallos Pollito}

Engenheiro Florestal

\author{
Orientador: Prof. Dr. MARIO TOMAZELO FILHO
}

Tese apresentada à Escola Superior de Agricultura "Luiz de Queiroz", Universidade de São Paulo, para obtenção do título de Doutor em Recursos Florestais, com opção em Silvicultura e Manejo Florestal.

P I R A C I C A B A

Estado de São Paulo - Brasil

Março - 2004 
Dados Internacionais de Catalogação na Publicação (CIP)
DIVISÃO DE BIBLIOTECA E DOCUMENTAÇÃO - ESALQ/USP

Zevallos Pollito, Percy Amilcar

Dendrologia, anatomia do lenho e "status" de conservação das espécies lenhosas dos gêneros Cinchona, Croton e Uncaria no estado do Acre, Brasil / Percy Amilcar Zevallos Pollito. - - Piracicaba, 2004.

181 p. : il.

Tese (doutorado) - Escola Superior de Agricultura Luiz de Queiroz, 2004.

Bibliografia.

1. Anatomia vegetal 2. Conservação de planta 3. Dendrologia 4. Distribuição geográfica 5. Euforbiacea 6. Plantas lenhosas 7. Rubiacea I. Título

CDD 634.983 
Dedico

A minha mãe Isabel Pollito e

filhos Fernando e Teresa 


\section{AGRADECIMENTOS}

Ao Dr. Mário Tomazello Filho, pela sua amizade, orientação, dedicação e paciência no desenvolvimento da presente pesquisa,

Aos Drs. Marcílio de Almeida, Inês Cordeiro, Antônio Natal Gonçalves, Ricardo Ribeiro Rodrigues, Edenise Segala Alves e Vinícius Castro Souza, pelas sugestões apresentadas na presente Tese de Doutorado,

Ao Dr. Ricardo Secco, pela permissão da revisão das exsicatas do Herbário do Museu Paraense Emílio Goeldi, Belém-Pará, pela sua amizade e apoio na identificação taxonômica,

Ao Dr. Claudio Sergio Lisi, por sua amizade e participação na Comissão Julgadora do Exame Geral de Qualificação,

À Técnica Maria Aparecida R. Bermúdez pela sua amizade e colaboração na preparação do material anatômico do lenho das espécies,

Aos Ms.Sc. Evandro Ferreira, Marcos Silveira e Silvia Brilhante, do Herbário do Parque Zoobotânico da Universidade Federal do Acre-HPZ, pela amizade, permissão da revisão das exsicatas do Herbário e uso do laboratório do HPZ,

Ao M.Sc. Geraldo José Zenid, do Instituto de Pesquisas Tecnológicas do Estado de São Paulo S.A.-IPT, pelo sua apoio nas descrições anatômicas do lenho das espécies, 
À família Pereira: Márcio, Regina, David e Johara, por sua grande amizade durante toda a minha permanência no Brasil, fazendo-me sentir como em casa. Assim como à Sra. Cecília de Almeida, pela sua amizade e conselhos de vida,

À família Moya: Roger, Eliza, Christian e Cristopher, por sua amizade sincera,

Aos meus amigos: Dr. Diniz Fronza, Dr. Waldo Francisco, M.Sc. Eliza Takashiba, M.Sc. Javier A. Vásquez Castro, Eng. Saulo Salaber Souza e Silva e Econ. Mauro Da Silva pela sua amizade,

À Organização de Estados Americanos-OEA, pelo oferecimento da Bolsa de Estudos que permitiu desenvolver a presente pesquisa,

À Faculdade de Ciências Florestais da Universidade Nacional Agrária La Molina, Lima-Peru, pela permissão para fazer os meus estudos doutorais,

À Secretaria de Meio Ambiente e Recursos Naturais do Governo do Estado do Acre-SEMA, Instituto Brasileiro do Meio Ambiente e dos Recursos Naturais Renováveis, IBAMA-Acre e as Prefeituras dos Municípios de Brasiléia, Cruzeiro do Sul, Epitaceolândia, Mâncio Lima, Rio Branco, Sena Madureira, Tarauacá e Xapurí, pelo apoio nas coletas dos materiais botânicos,

Aos Herbários do Brasil (ESA, HPZ, HRCB, IAN, INPA, MG, R, RB, SP, SPB, SPSP, UEC e UNBA), da Bolívia (LPB) e do Peru (MOL e USM) pelo apoio oferecido na revisão das exsicatas dos gêneros estudados. 


\section{SUMÁRIO}

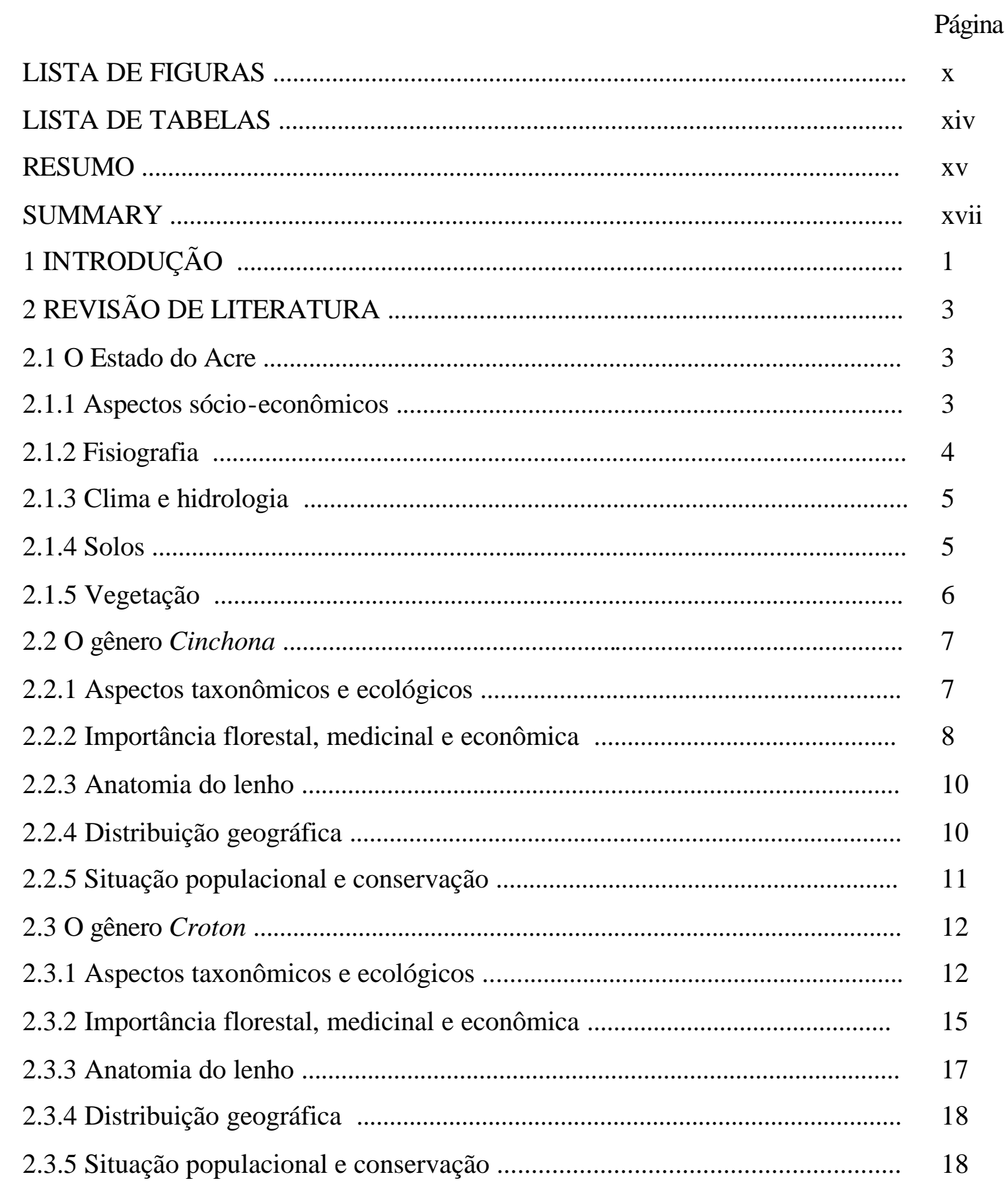


2.4 O gênero Uncaria ……………………………………............................. 19

2.4.1 Aspectos taxonômicos e ecológicos …………………………………….... 19

2.4.2 Importância florestal, medicinal e econômica ................................................ 21

2.4.3 Anatomia do lenho ................................................................................. 23

2.4.4 Distribuição geográfica .............................................................................. 23

2.4.5 Situação populacional e conservação ……………………………………….... 23

3 MATERIAL E MÉTODOS ........................................................................ 25

3.1 Revisão de herbários, bibliotecas e "sites" ....................................................... 25

3.2 Amostragem de campo ................................................................................. 27

3.3 Coleta e observações do material botânico .......................................................... 27

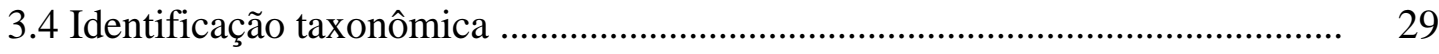

3.5 Caracterização e ilustração das espécies ............................................................ 29

3.6 Caracterização do lenho ............................................................................... 30

3.6.1 Maceração ……………………………………………………………... 30

3.6.2 Polimento das seções de estudo ................................................................ $\quad 30$

3.6.3 Avaliação das dimensões das células do lenho …………………………….... 30

3.6.4 Preparo e montagem das lâminas histológicas ..................................................... 31

3.6.5 Descrição anatômica do lenho ........................................................................ 31

3.7 Distribuição geográfica ..................................................................................... 31

3.7.1 Critérios geográficos ........................................................................... 32

3.7.2 Critérios de localização ...……………………………………………….... 32

3.7.3 Distribuição particular .................................................................................. 32

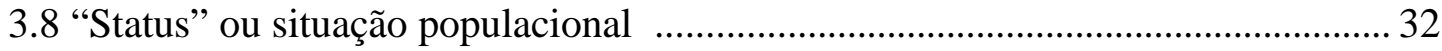

3.8.1 Abundância no campo …………………………………............................. 32

3.8.2 Antigüidade de coleções ........................................................................... 32

3.8.3 Posição em áreas expostas ............................................................................ 32

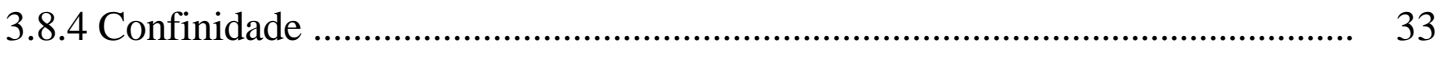

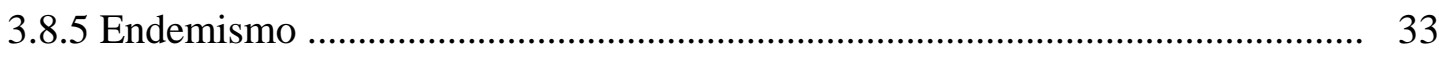

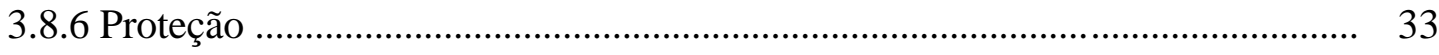

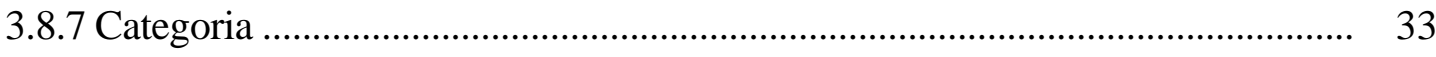




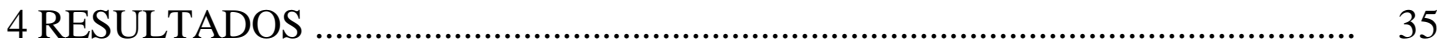

4.1 Cinchona amazonica Standl. ...................................................................... 35

4.1.1 Caracterização dendrológica ....................................................................... 35

4.1.2 Caracterização anatômica do lenho ............................................................... 36

4.1.3 Distribuição geográfica ............................................................................. 37

4.1.4 "Status" ou situação populacional ................................................................. 38

4.2 Croton billbergianus Müll. Arg. …………………………………………..... 43

4.2.1 Caracterização dendrológica …………………………………………….... 43

4.2.2 Caracterização anatômica do lenho .................................................................. 44

4.2.3 Distribuição geográfica ………………………………………………….... 45

4.2.4 "Status" ou situação populacional .................................................................. 46

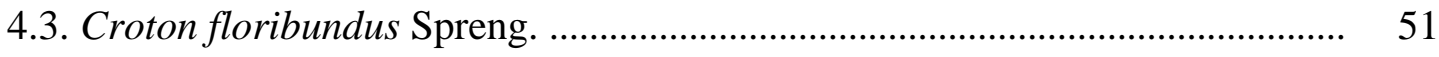

4.3.1 Caracterização dendrológica …………………………………………..... 51

4.3.2 Caracterização anatômica do lenho ............................................................... 52

4.3.3 Distribuição geográfica ............................................................................. 53

4.3.4 "Status" ou situação populacional ………………………………………..... 54

4.4 Croton lechleri Müll. Arg. ............................................................................. 59

4.4.1 Caracterização dendrológica ……………………………………………... 59

4.4.2 Caracterização anatômica do lenho ................................................................ 60

4.4.3 Distribuição geográfica ……………………………………………………... 61

4.4.4 "Status" ou situação populacional .................................................................. 61

4.5 Croton matourensis Aubl. ............................................................................... 67

4.5.1 Caracterização dendrológica ......................................................................... 67

4.5.2 Caracterização anatômica do lenho ................................................................. 68

4.5.3 Distribuição geográfica ………………………………………………….... 69

4.5.4 "Status" ou situação populacional ................................................................. 70

4.6 Croton palanostigma Klotzsch ..................................................................... 75

4.6.1 Caracterização dendrológica ...................................................................... 75

4.6.2 Caracterização anatômica do lenho ................................................................. 76

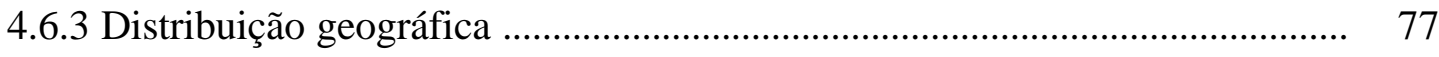


4.6.4 "Status" ou situação populacional ................................................................. 78

4 .7 Uncaria guianensis (Aubl.) J.F. Gmel. ......................................................... 83

4.7.1 Caracterização dendrológica …………………………………………….... 83

4.7.2 Caracterização anatômica do lenho ................................................................. 84

4.7.3 Distribuição geográfica .............................................................................. 84

4.7.4 "Status" ou situação populacional ................................................................. 86

4.8 Uncaria tomentosa (Willd. ex Roem. \& Schult.) DC. ......................................... 91

4.8.1 Caracterização dendrológica .......................................................................... 91

4.8.2 Caracterização anatômica do lenho ................................................................. 92

4.8.3 Distribuição geográfica ................................................................................... 93

4.8.4 "Status" ou situação populacional …………………………………………... 94

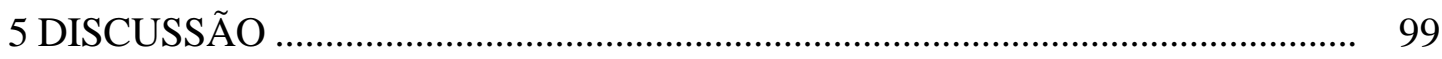

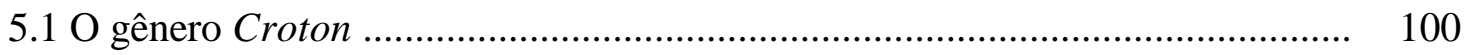

5.1.1 Identificação das espécies e dendrologia ..................................................... 100

5.1.2 Estrutura anatômica do lenho ...................................................................... 101

5.1.3 Distribuição geográfica ……………………......................................... 103

5.1.4 "Status" de conservação ou situação populacional .............................................. 104

5.2 Os gêneros Cinchona e Uncaria ............................................................... 105

5.2.1 Identificação das espécies e dendrologia ..................................................... 105

5.2.2 Estrutura anatômica do lenho ..................................................................... 106

5.2.3 Distribuição geográfica .............................................................................. 107

5.2.4. Status de conservação ou situação populacional .......................................... 108

6 CONCLUSÕES ……………………………………................................ 109

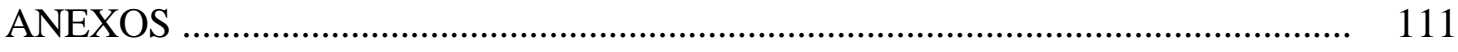

REFERÊNCIAS BIBLIOGRÁFICAS _............................................................ 158 


\section{LISTA DE FIGURAS}

Página

1 Localização geográfica do Estado do Acre no Brasil e na América Latina (a) e pontos de amostragem e de observação no Estado do Acre (b)

2 Cinchona amazonica Standl. - ramo terminal (a), pubescência da face abaxial (c) e adaxial (c) de folha jovem, pubescência da face abaxial (d) e adaxial (e) de folha adulta (d, e )

3 Cinchona amazonica - (a) árvore em pé, (b) casca externa, (c) casca interna, (d) ramo terminal

4 Cinchona amazonica - (a) seção transversal (10x), (b) seção transversal (50x), (c) seção longitudinal tangencial (50x), (d) seção longitudinal radial do lenho (50x)

5 Distribuição geográfica de Cinchona amazonica no Brasil (a) e na América Latina (b)

6 Croton billbergianus Müll.Arg. - ramo terminal com inflorescência (a), pêlos da face abaxial (b) e adaxial (c) da folha, glândulas na parte adaxial (d), glândulas na base da folha face abaxial (e), pêlo escamo-estrelado (f), pétalas na face abaxial (g) e adaxial (h), disco glandular (i), flor feminina (j) e gineceu não fecundada (l), flor e gineceu fecundado $(m, n)$, estames e antera (o, p, q), flor masculina (r)

7 Croton billbergianus - (a) arvoreta em pé, (b) casca externa e interna, (c) ramo terminal, (d) glândulas da folha

8 Croton billbergianus - seção transversal (10x), (b) seção transversal (50x), (c) seção longitudinal tangencial (50x), (d) seção longitudinal radial do lenho (50x) 
9 Distribuição geográfica de Croton billbergianus no Brasil (a) e na

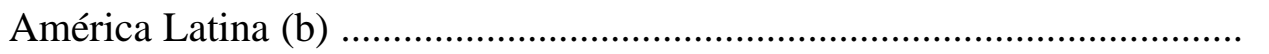

10 Croton floribundus Spreng. - ramo terminal com inflorescência (a), pubescência na folha face abaxial (b) e face adaxial glabra (c), glândula na base da folha face abaxial (d), flor feminina (e) e gineceu não fecundado (f), flor feminina (g) e gineceu fecundado (h), disco com inserção de pétalas e estames (i), flor masculina (j), estames e antera (l, m, n), pétalas na face abaxial e adaxial (o, p), pêlo estrelado da flor (q), pêlos da folha $(\mathrm{r}, \mathrm{s})$

11 Croton floribundus - (a) arvoreta em pé, (b) casca externa e interna, (c) ramo terminal com folhas e inflorescência, (d) glândulas da folha

12 Croton floribundus - (a) seção transversal (10x), (b) seção transversal (50x), (c) seção logitudinal tangencial (50x), (d) seção longitudinal radial do lenho (50x)

13 Distribuição geográfica de Croton floribundus no Brasil (a) e na América Latina (b)

14 Croton lechleri Müll.Arg. - ramo terminal com inflorescência (a), pubescência da folha face abaxial (b) e adaxial (c), glândulas na superficie da face adaxial (d), glândulas na base da folha face adaxial (e), flor feminina (f) e gineceu não fecundado (g), flor masculina (h), disco glandular da flor masculina $(i, j)$, estames $(1, m)$, antera $(n)$, pétalas fase abaxial (o) e adaxial (p) da flor masculina, pêlo da flor (q), pêlo da folha (r)

15 Croton lechleri - (a) árvore em pé, (b) casca externa e interna, (c) ramo terminal com folhas e inflorescência, (d) glândulas da folha

16 Croton lechleri - (a) seção transversal (10x), (b) seção transversal (50x), (c) seção longitudinal tangencial (50x), (d) seção longitudinal radial do lenho $(50 \mathrm{x})$

17 Distribuição geográfica de Croton lechleri no Brasil (a) e na América Latina (b) 
18 Croton matourensis Aubl. - ramo terminal com inflorescência (a), pubescência da folha face abaxial (b), pubescência na face adaxial (c), glândulas na base da folha face adaxial (d), glândulas na superfície da face adaxial (e), flor feminina e gineceu não fecundado (f, g), flor masculina (h), disco glandular da flor masculina (i, j), estames e antera $(1, m, n)$, pétalas face abaxial e adaxial da flor masculina $(o, p)$, pêlo da flor (q), pêlos da folha (r)

19 Croton matourensis - (a) árvores em pé, (b) casca externa e interna, (c) ramo terminal da regeneração natural com detalhe de estípula e pêlos, (d) inflorescência e frutos

20 Croton matourensis - (a) seção transversal (10x), (b) seção transversal (50x), (c) seção longitudinal tangencial (50x), (d) seção longitudinal radial do lenho $(50 \mathrm{x})$

21 Distribuição geográfica de Croton matourensis no Brasil (a) e na América Latina (b)

22 Croton palanostigma Klotzsch - ramo terminal com inflorescência (a), pubescência da folha face abaxial (b), pubescência na face adaxial (c), glândulas na folha face abaxial (d), detalhe da glândula (e), glândulas na superfície da face adaxial (f), flor feminina e gineceu $(\mathrm{g}, \mathrm{h})$, flor masculina (i), disco glandular da flor masculina (j), pêlo da flor masculina (1), estames e antera (m, n, o), pétalas face abaxial e adaxial da flor masculina (p, q), pêlo da folha fase abaxial (r), pêlo da folha face adaxial (s)

23 Croton palanostigma - (a) árvore em pé, (b) casca externa e interna, (c) inflorescência com flores masculinas, (d) ramo terminal com inflorescências imaturas

24 Croton palanostigma - (a) seção transversal (10x), (b) seção transversal (50x), (c) seção longitudinal tangencial (50x), (d) seção longitudinal radial do lenho (50x) 
25 Distribuição geográfica de Croton palanostigma no Brasil (a) e na

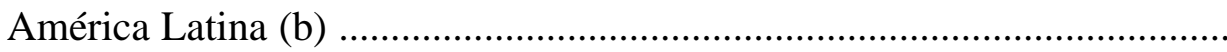

26 Uncaria guianensis (Aubl.) J.F. Gmel. - ramo terminal com inflorecência e frutos (a), pubescência face abaxial folha nova e velha (b,c), inflorescência capítulo (d), flor (e), inflorescência com flores fecundadas (f), cálice da flor (g)

27 Uncaria guianensis - (a) arbusto na borda da floresta, (b) casca externa e interna, (c) espinhos, (d) frutos imaturos

28 Uncaria guianensis - (a) seção transversal (10x), (b) seção transversal (50x), (c) seção longitudinal tangencial (50x), (d) seção longitudinal radial do lenho $(50 \mathrm{x})$

29 Distribuição geográfica de Uncaria guianensis no Brasil (a) e na América Latina (b)

30 Uncaria tomentosa (Willd. ex Roem. \& Schult) DC. - ramo terminal (a), detalhe espinhos no caule (b), pubescência face abaxial folha nova e velha $(c, d)$, pubescência na face adaxial folha nova e velha (e,f), inflorescência imatura $(\mathrm{g})$, detalhe de nervura da folha com pubescência face abaxial e adaxial $(\mathrm{h}, \mathrm{i})$

31 Uncaria tomentosa - (a) liana no interior do sub-bosque, (b) casca interna e lenho verde, (c) ramo terminal, (d) espinhos

32 Uncaria tomentosa - (a) seção transversal (10x), (b) seção transversal (50x), (c) seção logitudinal tangencial (50x), (d) seção longitudinal radial do lenho (50x).

33 Distribuição geográfica de Uncaria tomentosa no Brasil (a) e na América Latina (b) 


\section{LISTA DE TABELAS}

Página

1 Herbários nacionais e internacionais

2 Localidades de amostragem, coleta e observação do material dendrológico e anatômico dos gêneros Cinchona, Croton e Uncaria .........

3 Resumo da caracterização da anatomia do lenho das espécies dos Gêneros Cinchona, Croton e Uncaria

115

4 Informação do material botânico nos herbários do gênero Cinchona ......... 118

5 Informação do material botânico nos herbários do gênero Croton .............. 119

6 Informação do material botânico nos herbários do gênero Uncaria ........... 143

7 Resultados do diagnóstico do status de conservação das espécies dos gêneros Cinchona, Croton e Uncaria ..... 


\section{DENDROLOGIA, ANATOMIA DO LENHO E "STATUS" DE CONSERVAÇÃO DAS ESPÉCIES LENHOSAS DOS GÊNEROS Cinchona, Croton e Uncaria NO ESTADO DO ACRE, BRASIL}

Autor: PERCY AMILCAR ZEVALLOS POLLITO

Orientador: Prof. Dr. MARIO TOMAZELLO FILHO

\section{RESUMO}

No presente trabalho foram estudadas 8 espécies lenhosas dos gêneros Cinchona (C. amazonica Standl.), Croton (C. billbergianus Müll.Arg., C. floribundus Spreng., C. lechleri, Müell.Arg., C. matourensis Aubl., C. palanostigma Klotzsch) e Uncaria (U. guianensis (Aubl.) J.F. Gmel. e U. tomentosa (Willd. ex Roem. \& Schult.) DC.) de interesse medicinal e ocorrentes no Estado do Acre, Brasil. Dessas plantas foram analisadas as características dendrológicas, a estrutura anatômica do lenho, sua distribuição geográfica e "گtatus" de conservação. A pesquisa consistiu de visitas de campo a diferentes regiões do Estado, coleta de material botânico e do lenho das plantas, levantamento e estudo das exsicatas das espécies em herbários nacionais e internacionais da América do Sul, revisão bibliográfica das espécies na literatura e "sites" especializados, descrição dos parâmetros dendrológicos e da estrutura antômica do lenho das espécies em laboratório, possibilitando a identificação das espécies dos 3 gêneros. As características dendrológicas vegetativas das plantas mostraram variações, resultado das adaptações ao meio ambiente, da idade e de sua ampla distribuição geográfica. A estrutura anatomica do lenho foi mais distinta entre famílias (Euphorbiaceae e 
Rubiaceae) e gêneros (Cinchona, Croton, Uncaria) e menos nas espécies, constituindose em parâmetro importante e auxiliar na sua identificação. As plantas de Cinchona amazonica apresentaram baixa intensidade populacional, embora com ampla distribuição no Estado do Acre, em outros estados brasileiros e nos países amazônicos. No gênero Croton, as plantas de C.palanostigma mostraram distribuição quase pontual no Acre e extensa na Amazônia e menos ampla na América Latina; C. floribundus com ocorrência pontual no Acre, distribuição concentrada no Estado de São Paulo e em outros estados brasileiros e no Paraguai; C. matourensis encontram-se bem distribuídas no Acre e em outros estados brasileiros e países amazônicos, até o Panamá; C. lechleri ocorrem somente no sudeste do Estado do Acre, na Bolívia, Colômbia, Peru e Equador; $C$. billbergianus encontram-se bem distribuídas no Estado do Acre, escassa em outros estados amazônicos, ocorrendo em outros países da América Latina até o México. As plantas de Uncaria guianensis e $U$. tomentosa foram as de maior abundância no Estado do Acre e em toda a Amazônia brasileira, sendo U. tomentosa de menor abundância e distribuição muito ampla ocorrendo, inclusive, até a América Central. Com respeito ao "status" de conservação, as plantas de Croton billergianus, C. matourensis e Uncaria guianensis foram incluídas na categoria LC (comuns e abundantes ou fora de perigo), Cinchona amazonica, Croton lechleri e C. palanostigma em CR (perigo crítico), Uncaria tomentosa em VU (perigo a médio prazo) e Croton floribundus em DD (informação insuficiente). A presença destas espécies não foi constatada nas unidades de conservação do Estado do Acre e, no momento, as florestas onde ocorrem estão sendo exploradas para a extração da madeira, de fármacos e para a ampliação da fronteira agropecuária. Nos herbários das instituiçõos de pesquisa e de ensino do Estado do Acre as coleções de plantas das espécies de Cinchona, Croton e Uncaria são escassas em comparação com as de outros Estados do Brasil e dos países visitados. 


\title{
DENDROLOGY, WOOD ANATOMY AND "STATUS" CONSERVATION OF SPECIES OF THE Cinchona, Croton AND Uncaria'S GENUS FROM ACRE STATE, BRASIL
}

\author{
Author: PERCY AMILCAR ZEVALLOS POLLITO \\ Adviser: Prof. Dr. MARIO TOMAZELLO FILHO
}

\section{SUMMARY}

This research studied eight wood species of the genus Cinchona (C. amazonica Standl.), Croton (C. billbergianus Müll.Arg. C. floribundus Spreng.; C. lechleri, Müll.Arg.; C. matourensis Aubl. and C. palanostigma Klotzsch) and Uncaria (U. guianensis (Aubl.)J.F. Gmel. and U. tomentosa (Willd. ex Roem. \& Schult.)DC.). All of them with medicinal interest, grown in the state of Acre (Brazil). The research consisted mainly in: field work in different regions of the state of Acre and botanical and plants collections, raising the exsiccates of the mentioned species in the most important national and international herbariums of South America, a wide bibliographical review concerning these species, dendrology description and the macro and microscopy description of the wood. The ve getative dendrological characteristics of these species showed variations with age adaptations and geographical distribution. The anatomy structures were different between families (Euphorbiaceae and Rubiaceae) and genus (Cinchona, Croton, Uncaria) and less within species. These results can be used for identification of these genus. In the order hand, this study shows that Cinchona 
amazonica had low distribution in Acre State, other Brazilian states and Amazonian countries. For Croton genus as C. palanostigma showed an almost punctual distribution in Acre, although had high distribution on the Amazon region and lowest on Latin America; C. floribundus with punctual occurrence on the Acre State and concentrated distribution in Sao Paulo State, other Brazilian States and in Paraguay; C. matourensis had high distribution in Acre, other Brazilian states and Amazonian countries, reaching up to Panama; C. lechleri grew only in the south east of Acre, Bolivia, Colombia, Peru and Ecuador; C. billbergianus was found well distributed in Acre, less abundant in other Amazon states and Latin countries and reaching up to Mexico. Uncaria guianensis and $U$. tomentosa were the most abundant species in Acre state and in all the Brazilian Amazon, and the $U$. tomentosa in Brazil can be considered less abundant, although with a wider distribution reaching inclusive the Central America. Concerning the conservation "status", C billbergianus, C. matourensis and $U$. guianensis were included in the category LC (common and abundant $\alpha$ out of danger); Cinchona amazonica, Croton lechleri and C. palanostigma on CR (critical danger), Uncaria tomentosa on VU (medium term danger) and Croton floribundus on DD (insufficient information). One of the most important aspects to mention is that there were no evidence of any presence of these species in the conservation unites in the State of Acre, and in the forests where they occur. Also, they are cuttings for raw material for wood, pharmacological exploration and farm and cattle frontiers amplification.. This situation was verified in the State of Acre for the lower collection of plants of Cinchona, Croton and Uncaria in relation to other states in Brazil and in other countries visited. 


\section{INTRODUÇÃO}

No final do século passado e no começo do presente a procura por recursos florestais para fins medicinais assumiu significativa importância devido, fundamentalmente, ao sucesso de muitas espécies vegetais no tratamento e cura de inúmeras enfermidades (Zavala \& Zevallos, 1996). Os estudos etnobotânicos resgataram os conhecimento dos povos indígenas e demais populações e, somados aos resultados das estudos fitoquímicos e farmacológicos, permitiram descobrir o princípio ativo de importantes compostos das plantas das matas nativas.

Apesar da existência de uma florescente indústria farmacêutica que pesquisa e desenvolve novos remédios a Organização Mundial da Saúde estima que $80 \%$ da população mundial depende da medicina tradicional e $85 \%$ desta utiliza as plantas medicinais, seus extratos vegetais e princípios ativos (IUCN et al., 1993).

As florestas amazônicas contêm um significativo número de espécies vegetais com compostos químicos complexos que são do conhecimento exclusivo dos herbolários e curandeiros. Os constituintes dessas plantas medicinais -flores, sementes, folhas, cascas, látex, madeiras, etc.- são comercializados nas praças e ruas chegando, desta forma, até o conhecimento do pesquisador (Alarcón \& Mena, 1994).

O Brasil é considerado como o país de flora mais rica do mundo, com 55-60 mil espécies, de um total de mais de 270 mil espécies de plantas vasculares reconhecidas, com grande potencial alimentar, medicinal e científico (Prance, 1977; Giulietti \& Forero, 1990; IUCN, 1998; Calderón, 2002), assumindo uma posição chave na conservação genética dessas espécies (Mittermeier et al., 1997).

O Estado do Acre, na Amazônia Ocidental, com 93\% de seu território coberto de florestas pluviais, possui o maior patrimônio genético vegetal da região norte do Brasil (IMAC, 1991). A redução da sua cobertura vegetal (5\% ao ano), conseqüência da exploração madeireira e ampliação da fronteira agropecuária, pode levar a extinção de 
parte da flora ainda desconhecida e potencial como fonte de produtos medicinais, madeireiros e alimentícios (Menezes, 1994).

Das inúmeras plantas com substâncias químicas utilizadas nos tratamentos terapêuticos, estão incluídas as dos gêneros Cinchona, (quinina, para as febres decorrentes ou malária) (Zevallos, 1989), Uncaria, (alcalóides oxindólicos e o ácido quinóvico, com propriedades antiflamatórias e estimulantes do sistema imunológico) (Lombardi \& Zevallos, 1999) e Croton (taspina com propriedades antiflamatórias, antibióticas e cicatrizantes) (Meza \& Ayala, 1998).

Os estudos desses gêneros nos países andinos da Amazônia têm sido relativamente intensos pela sua importância farmacêutica e econômica (Forero et al., 2000; Ocampo-Sánchez, 2000; Zevallos et al., 2000) sendo, porém, reduzidos no Brasil (Schultes, 1979; Deprete \& Cortez, 2002). Para essas espécies de plantas tropicais com aplicação medicinal devem de ser aprofundados os estudos de dendrologia, anatomia, distribuição geográfica, situação populacional, etc., para a tomada de decisões estratégicas visando sua conservação e utilização sustentável.

Neste contexto, a presente pesquisa teve como objetivos a (i) caracterização dendrológica e anatômica do lenho das espécies dos gêneros Cinchona, Croton e Uncaria do Estado do Acre-Brasil, (ii) determinação da sua distribuição geográfica para definir seu padrão de ocorrência e (iii) determinação do seu "status de conservação" ou situação populacional, para conhecer o grau de retração ou expansão na região. 


\section{REVISÃO DE LITERATURA}

\subsection{O Estado do Acre}

O Estado do Acre, parte da Bolívia e incorporado ao Brasil em 1903 (Calixto, 1974) está situado no extremo sudoeste da Amazônia brasileira (latitudes de $7^{\circ} 07^{\prime} 00$ '”$11^{\circ} 08^{\prime} 00^{\prime}$ S e longitudes de $66^{\circ} 30^{\prime} 00^{\prime}-74^{\circ} 00^{\prime} 00^{\prime}$ W) e possui uma superfície territorial de 153.149,9 $\mathrm{Km}^{2}$, correspondendo a 3,9\% da área amazônica legal e a 1,8\% do território nacional (IBGE, 1995). Faz fronteiras internacionais com o Peru e a Bolívia e nacionais com os Estados do Amazonas e de Rondônia (Figura 1).

\subsubsection{Aspectos sócio-econômicos}

A população do Estado do Acre é de 483.726 habitantes (IMAC, 2000) sendo $68 \%$ concentrada nas áreas urbanas de Rio Branco e de outras cidades importantes (Cruzeiro do Sul, Sena Madureira e Tarauacá.). As mulheres correspondem a 49,4\% e os homens a 50,6\%, distribuídos em uma faixa etária de 0-14 anos (44,1\%); de 15-59 anos $(51,1 \%)$ e acima de 60 anos $(4,8 \%)$. O índice de mortalidade é de 4/1000 habitantes e a taxa de mortalidade infantil indica a existência de 46 óbitos antes de completar 1 ano de idade, para 1.000 crianças nascidas vivas (FUNASA, 1999).

A floresta sustenta a economia acreana sendo a indústria extrativa a atividade fundamental da população. A extração de madeira de alto valor comercial atinge $200.000 \mathrm{~m}^{3} / \mathrm{ano}$, podendo ser triplicada pela abertura do acesso ao Oceano Pacífico (Foster et al., 2002). Atividades complementares são a extração da borracha, da castanha e a pecuária.

O Acre é o maior produtor de borracha do País, com 2,5 mil famílias dedicadas ao trabalho nos seringais localizados nas bacias dos rios Acre, Purus e Juruá (Araújo, 1999). A queda do preço pelo aumento da oferta do produto no mercado internacional e 
a expansão das fronteiras agrícolas, tornaram secundária essa atividade. A coleta e comercialização das sementes de castanha-do-pará constituem-se, também, em atividades básicas dos seringueiros como ocupação subsidiária na época das chuvas, sem apresentar safra regular (CTA, 1998).

A floresta Amazônica, além da madeira e do látex, permite obter produtos como alimentos, medicamentos naturais e cosméticos. O óleo de copaíba é um medicamento bastante utilizado na Amazônia (Antunes et al., 1998); o fruto da palmeira açaí e palmito da pupunha, conquistam mercado nas região sudeste e centro sul do Brasil; a folha da pimenta longa é utilizada como fixador de perfumes e o urucum é exportado para as indústrias de cosméticos (IMAC, 2000).

$\mathrm{Na}$ agricultura algumas lavouras como as de mandioca, arroz, banana e milho dentre outras, têm importância econômica e são essenciais para a subsistência da população. A pecuária destaca-se pelos rebanhos de gado bovino (410 mil cabeças), suínos (172,2 mil cabeças) e ovinos (26 mil cabeças) (IMAC, 2000).

A atividade industrial no Estado do Acre é voltada para a produção alimentícia, madeireira, cerâmica e de mobiliário, sendo o comércio feito quase todo por via fluvial com produtos exportados convergindo em quase sua totalidade para os Estados do Amazonas e do Pará (IMAC, 2000).

\subsubsection{Fisiografia}

O relevo é composto, predominantemente, por rochas sedimentares que formam uma plataforma regular ou planície Amazônica, que desce suavemente desde os $300 \mathrm{~m}$ em cotas da ordem de $200 \mathrm{~m}$ desde as fronteiras com a Bolívia e o Peru, para pouco mais de 100 m nos limites com o Estado do Amazonas; planícies aluviais margeando os rios e pelos níveis de terraços descontínuos, remanescentes de sedimentos desenvolvidos durante o Pleistoceno Superior (Brasil, 1976 \& 1977). No extremo ocidental situa-se o ponto culminante do Estado, onde a estrutura do relêvo se modifica para formar o complexo fisiográfico da Serra do Divisor, de idade Terciária desenvolvida sobre a 
Formação Solimões, e uma ramificação da Serra Peruana de Contamana, apresentando uma altitude máxima de 600 a 650 m (Brasil, 1977).

\subsubsection{Clima e hidrologia}

O clima do Acre é do tipo tropical úmido, caracterizado por altas temperaturas, elevados índices de precipitação pluviométrica e alta umidade relativa do ar. A temperatura média anual está em torno de $24,5^{\circ} \mathrm{C}$, com a máxima de $32{ }^{\circ} \mathrm{C}$, uniforme em todo o Estado, e a mínima variando em função da exposição aos sistemas climáticos extra-tropicais (Cruzeiro do Sul 10; Brasiléia 17,4; Rio Branco 20,2 e Tarauacá 19,9 ${ }^{\circ} \mathrm{C}$ ). $\mathrm{Na}$ estação seca, são comuns as friagens que provocam brusca queda de temperatura. $\mathrm{O}$ índice pluviométrico chega a 1.600-2.750 mm/ano e tende a aumentar no sentido sudeste-noroeste com meses menos chuvosos (junho-agosto). A umidade relativa apresenta-se em níveis elevados durante o ano com médias mensais de 80-90\% (IMAC, 2000).

A bacia hidrográfica do Estado do Acre pertencente à Amazônica, ocupa $153.149,9 \mathrm{~km}^{2}$, com os principais rios Juruá, Tarauacá, Muru, Embirá, Xapuri, Purus, Iaco e Acre, formando uma complexa e bem distribuída drenagem sobre rochas sedimentares, sem a presença de cachoeiras. Os rios com forma meândrica e pequenos trechos retilíneos formam bancos de areia nos leitos aumentando as dificuldades e as distâncias da navegação fluvial e causando implicações severas para o acesso, por constituirem o mais importante meio de transporte no Estado (IMAC, 2000; FUNTAC, $1990 \& 1991)$.

\subsubsection{Solos}

Os solos são de origem sedimentar tendo, em várias áreas, influencia calcária, constituída predominantemente por solos dos grupo Podzólicos Vermelhos Amarelos; na região oeste, Podzólicos Vermelhos Amarelos Eutróficos e Cambissolos Eutróficos, e região leste Podzólicos Vermelhos Amarelos distróficos associados a Latossolos 
Vermelho Amarelos, além de Hidromórficos Gleyzados (FUNTAC, 1991 e EMBRAPA, 1999).

Em geral, os solos são extremamente vulneráveis à erosão quando é retirada a sua cobertura vegetal. No Vale do Acre os solos produzem culturas agrícolas nos primeiros anos após a derrubada e queima da floresta em decorrência dos nutrientes adicionados pelas cinzas. Sendo abandonados, regeneram-se formando as capoeiras (FUNTAC, 1991). EMBRAPA (1999) revelou que a degradação do solo em áreas desmatadas do Acre e o plantio de gramíneas para pastagem não adaptadas à região ameaçam inviabilizar $50 \%$ da pecuária do estado.

\subsubsection{Vegetação}

O Acre abriga vegetação composta basicamente da Floresta Amazônica Tropical Aberta e Tropical Densa com árvores de grande porte (IMAC, 2000 e FUNTAC, 1990). A Floresta Tropical Aberta apresenta sub-bosques com cipó (maioria das árvores com copas revestidas por cipós, com aspecto de torres), palmeiras (encontradas geralmente em áreas inundadas temporariamente e ao longo dos rios) e bambu (encontrado no sub-bosque em quantidades variáveis, com maior intensidade de luz apresenta adensamento encobrindo as árvores). A Floresta Tropical Densa possui vegetação arbórea heterogênea com árvores de 30-50 m de altura e sub-bosque denso e de porte arbustivo proveniente de regeneração das árvores mais velhas (IMAC, 2000).

A ampliação da fronteira agropecuária e a exploração florestal é elevada $(5,5$ mil $\mathrm{km}^{2}$ ) e atinge o desmatamento das florestas em $60 \%$ da área de alguns municípios (ex: Epitaceolândia), ameaçando a flora e a fauna e provocando danos ambientais e impactos sócio-econômicos (Brasil, 1977 e INPE, 2000).

As áreas de vegetação contíguas com o Peru e a Bolívia correspondem a uma região com unidades geograficamente discretas com afinidade à vegetação andina, predominantemente na Serra do Divisor e nas terras baixas na bacia do Juruá no limite noroeste do estado, próximo à fronteira com o Peru (Dinnertein et al., 1995). Os paredões rochosos e solos rasos e instáveis da serra são cobertos por vegetação especial 
com alta concentração de elementos andinos (Dicranopygium rheithrophilum, Cyathea bipinnatifida, Ladenbergia spp, Cespedesia spathulacea, Eschweilera andina , Aegiphila spicata, Monolena primuliflora, Wettinia augusta, incluindo Aiphanes, Aphandra, Chamaedorea, Chelyocarpus, Dictyocaryum, Iriartea e Phytelephas (Kahn \& Ferreira, 1995).

\subsection{O gênero Cinchona}

\subsubsection{Aspectos taxonômicos e ecológicos}

O gênero Cinchona tem sido estudado intensamente desde a sua descoberta para a cura da malária no final do século XVI. No mundo foram descritas 38-50 espécies de árvores e 150 variedades de arbustos perenes, nas escarpas mornas e úmidas dos Andes, nas altitudes de 1.500-2.500 m, bem como na Amazônia (Steyermark, 1974; Stell, 1982; Gentry, 1993 e Bremer et al., 1995). São encontrados 167 registros de nomes científicos (Rea, 1995), sendo reconhecidos 23 por Anderson (1998).

De acordo com Cronquist (1988) este grupo pertence à família Rubiaceae, ordem Rubiales, Subclasse Asteridae, Classe Magnoliopsida, das Magnoliophytas. A família foi separada da ordem Gentianales em função da classificação filogenética de A. Englel (Hutchinson, 1967). Robbrecht (1988) a incluiu na subfamília da Cinchonoideae mas, desde DeCandolle (1830) até Anderson (1995 \& 1998), situa-se na Tribu Cinchoneae, que agrupa gêneros com sementes aladas. Bremer et al. (1998) e APG (2003), de acordo com uma análise cladística, reclassificaram as Rubiaceae nas Gentianales sob uma sustentação monofilética, voltando à ordem original, pertencente ao grupo mais elevado Euasteridae I.

Geralmente são árvores medianas $(15-20 \mathrm{~m}$ de altura) a pequenas, ocasionalmente arbustos, com ramificação dicotômica e com casca amarga (Rea, 1995). Folhas simples, grandes e vistosas, opostas e decusadas; oblongas, elípticas, ovais, abovadas, orbiculares e/ou subcordadas; freqüentemente avermelhadas quando adultas; papiráceas, cartáceas ou coriáceas; pecioladas ou com pecíolos curtos; com um par de estípulas médias ou grandes, livres ou inter-pecioladas, conatas na base e estreitamente 
triangular, abovadas, oblongas ou ligulares, persistentes ou caducas. Flores bissexuais, pequenas a médias, numerosas e muito aromáticas, em panículas terminais; cálice cupuliforme com 4 a 6 lóbulos pequenos, inteireformes ou redondos, pubescentes no interior; corola de 4 a 6 lóbulos, branca, creme-branca, rosa, cinza-lavanda ou vermelha, hipocrateriforme ou infundibuliforme, externamente com abundante pubescência; estames semi-exertos ou inclusos alternos e adnatos ao tubo da corola; gineceu de ovário ínfero, bicarpelar, bilocular e placentação axilar, com muitos óvulos. Fruto cápsula, subcilíndrica, elíptica ou oval-oblonga, bi-sulcada, com deiscência septicida, abrindo-se da base até o ápice, com muitas sementes. Sementes amplamente aladas, acuminadas ou obtusas nas pontas, denticuladas ou imbricadas. Embrião pequeno e albume carnoso (Steyermark, 1974; Gentry, 1993; Rea, 1995 e Anderson, 1998).

As espécies ocorrem em climas quentes e úmidos, com precipitação abundante e persistente, com nebulosidade o ano todo, nas zonas altas com topografia íngreme e nas partes baixas com colinas, sem influenciar no clima. Encontram-se em áreas com temperaturas de 6,5-24,9 ${ }^{\circ} \mathrm{C}$ e precipitações de 790-3.900 mm, com temperaturas e precipitações máximas no verão (Zevallos, 1989 e Ocampo-Sánchez, 2000).

No geral, ocorrem em regiões com solos de origem coluvial ou aluvial, profundos, de reação ácida e bem drenados, com textura areno-argiloso fino e abundante matéria orgânica (Ocampo-Sánchez, 2000; Zevallos, 1989 e Barquero, 1986).

Anderson (1998), fazendo uso da análise cladística propôs a inclusão de Cinchona amazonica Standl. no gênero Cinchonopsis, recém criado pelo autor.

\subsubsection{Importância florestal, medicinal e econômica}

As espécies do gênero Cinchona são consideradas universalmente como as que salvaram a humanidade da malária ou paludismo. Em 1643 foi reportada pelos jesuítas pela primeira vez na Europa, sendo utilizada marcadamente durante as 2 Guerras Mundiais (Zevallos, 1989 e Verveen, 1984). Compreendem várias espécies chamadas vulgarmente de "cascarilla", árvore da quina ou árvore do quinino, que contém quinina (alcalóide com propriedades antifebrífugas) das quais foram extraídas imensas 
quantidades do Peru e da Bolívia. Em 1820 após o isolamento do alcalóide quinina, seguiu-se uma feroz competição para identificar a espécie que contivesse o mais alto teor desse composto causando a extinção de populações de plantas de cinchonas selvagens, no início do século XIX e induzindo o estabelecimento de plantações das espécies. Com o sucesso dos holandeses no cultivo de Cinchona calisaya Wedd. em Java, esta tornouse o centro mundial de produção de quinina (Anderson, 1998).

Durante a $2^{\text {a }}$ Guerra Mundial, o Japão cortou o abastecimento de casca de Cinchona para a produção de quinina obrigando os Estados Unidos a organizarem expedições de busca e comercialização das espécies nos países andinos e reforçando as pesquisas para uma vacina ou alcalóides substitutos da Cinchona (Hodge, 1948 e Zevallos, 1989). O sucesso foi logrado pelo isolamento do anti-malárico cloroquina durante a $2^{\mathrm{a}}$ Guerra Mundial (Smit, 1987). Porém, em princípios de 1960, foram reportados casos de resistência da droga no sudeste asiático: a cloroquina não era efetiva contra a malária induzida pelo Plasmodium falciparum Welch (Smit,1987 e Warhurst, 1987). Desde então, outras formas do parasita apresentaram resistência aos medicamentos sintéticos, com a quinina natural extraída da casca da árvore de Cinchona, permanencendo o remédio ideal para a malária cerebral e outras formas de malária (Warhurst, 1987).

As espécies de Cinchona, de importância desde o século XVII são, atualmente, cultivadas em inúmeras regiões tropicais, com a produção anual 5.000-10.000 ton de casca e 400-500 ton de alcalóide, com 60\% da produção mundial destinada a indústria farmacêutica e 30-50\% a indústria agroalimentar (Rea, 1995 e Verpoorte et al., 1988).

Os compostos químicos das espécies do gênero Cinchona são os alcalóides quinólicos (quinina, quinidina, dihidroquinidina, cinconidina, cinconina e dehidrocinconina) e indólicos (dihidroquinamina e 3 epi-dihidroquinamina), com a quinina apresentando a mais alta atividade antimalárica (Verpoorte et al., 1988). A quinina e a quinidina são utilizadas, ao nível do miocardio, contra problemas de eretismo cardíaco, anginas precordiais; o clohidrato de quinina para esclerosis de origem hemorroidal; o escorbato de quinina, associada a vitamina B, para o tabagismo e para 
cãibra, ademais é analgésica e antipirética. (Rea, 1995). A quinina é usada como aditivo amargo nos alimentos e bebidas (Bruneton, 2001) e na indústria química nas catálises e nas imobilizações de matrizes poliméricas (Verpoorte et al., 1988).

A quinidina como antifibrilante é adequada no tratamento preventivo da taquicardia, justificando que 30-50\% da produção de quinina é transformada por meios físico-mecânicos em quinidina (Prinz, 1990 e Bruneton, 2001). Os alcalóides quinolínicos apresentam atividade contra o vírus da batata (Verpoorte et al., 1988) e os indólicos do tipo cincofilinas contra as bactérias gram-positivas (Rea, 1995).

Segundo Andersson (1998) as espécies de maior conteúdo de alcalóides foram Cinchona pubescens Valh (freqüentemente conhecida com o nome de C. succirubra Pav. ex Klotzsch) e C. calisaya (conhecida com o nome de C. ledgeriana (Howard) Bern. Moens ex Trimen.).

\subsubsection{Anatomia do lenho}

A literatura sobre a anatomia e propriedades tecnológicas do lenho é escassa uma vez que a casca é o constituinte mais importante nas espécies de Cinchona. Acosta (1960) estabeleceu no Equador o seu valor madeireiro, considerando de boa qualidade para tábuas e móveis (cor rosa ou avermelhada), de grã fina a média, textura média,

flexível e elástica, fácil de trabalhar, acabamento brilhante após lixamento e peso específico de $0,57 \mathrm{~g} / \mathrm{cm}^{3}$. As peças de madeira não racham ou se decompõem facilmente no campo, sendo usadas na construção de casas na zona rural (Zevallos, 1989).

\subsubsection{Distribuição geográfica}

As espécies de Cinchona de origem americana segundo Anderson (1998) têm como espécie ancestral de provável ocorrência nas florestas de neblina dos Andes Centrais quase ao final do Cretáceo, quando completou-se a formação das montanhas de baixas elevações. É nativa das florestas úmidas, geralmente acima de $100 \mathrm{~m}$ podendo chegar até 3000 m (Burger, 1993; Gupta, 1995 e Ocampo-Sánchez, 2000) entre as 
latitudes de $10^{\circ} \mathrm{N}-19^{\circ} \mathrm{S}$ (Van-Herten, 1987). Na Amazônia brasileira somente $C$. amazonica tem sido reportada até o nível do mar (Zevallos, 1989).

Como gênero do Neotrópico é nativo das florestas úmidas das regiões tropicais e subtropicais, desde a Bolívia Central até o norte da Colômbia e Venezuela, com ampla distribuição na América Central até o norte de Costa Rica (Ocampo-Sánchez, 2000).

Pela importância econômica da exploração da casca de quinina, Cinchona calisaya foi introduzida pelos ingleses e holandeses em outras partes do trópico úmido como no sudoeste da Índia e Java, nas montanhas do leste da África e do Zaire (Carvalho, 1944 e Carvalho \& Krug, 1944). No Brasil foi introduzida em 1868 nos Estados de Minas Gerais e do Rio de Janeiro, e C. succirubra em 1925 nos Estado de São Paulo e do Rio de Janeiro, não havendo sucesso no processo de aclimatação feita pelo Instituto Agronômico de Campinas. Segundo Anderson (1998) Cinchona succirubra foi introduzida nas Ilhas de Galápagos-Equador, onde converteu-se em uma planta invasora agressiva em comparação com a vegetação natural do arquipélago.

\subsubsection{Situação populacional e conservação}

Durante séculos a demanda de casca do gênero foi muito intensa, principalmente na Colômbia, Equador, Bolívia e Peru (Keeble, 1997), especialmente durante a $2^{\text {a }}$ Guerra Mundial. Constituindo-se em uma das principais fontes de renda, a extração causou a extinção em florestas inteiras, inclusive nas zonas de proteção e, segundo Anderson (1998) são ainda endêmicas nos trópicos, com sua população colocada em situação de perigo (Zevallos, 1989).

No século passado o aumento da malária obrigou os ingleses e holandeses a introduzirem o gênero Cinchona na Índia e na Indonésia, para a obtenção de maiores níveis de produção (Philip, 1995). No século XIX e XX novas plantações foram estabelecidas na África (Tanzânia, Uganda e Congo) e na América (Guatemala, Costa Rica, Bolívia e Brasil ) contendo a degradação das últimas florestas com as espécies do gênero (Trese \& Evans, 1987). 
Apesar de, aparentemente, haver diminuído a demanda por casca das espécies de Cinchona identificou-se no Equador um comércio clandestino no mercado interno e externo justificando, em 1998, o início de um projeto de manejo e fiscalização efetiva de plantas, promovendo a conservação, implantação de plantações e seu comércio legal (Buitrón, 2000).

No Peru, os relatórios sobre a exploração das espécies para a obtenção da casca desde séculos passados até as últimas décadas indicaram a indução da morte das árvores obrigando as instituições governamentais a proibirem a sua exploração e a incentivarem o seu plantio (Casas, 1999).

\subsection{O gênero Croton}

\subsubsection{Aspectos taxonômicos e ecológicos}

Croton é um dos maiores gêneros das Euphorbiaceae, abrangendo um número considerável de espécies no mundo (750-1.000) (Webster, 1994), das quais 400 são reportadas na América tropical e subtropical. Na região Amazônica, especialmente na Bolívia, Brasil, Colômbia, Equador e Peru é conhecido como sangue-de-grado ou sangue-de-drago (Gentry, 1993 e Gentry \& Forsyth, 1998). Algumas espécies são venenosas, apresentando glândulas na base das folhas e geralmente com exsudação de látex.

No Brasil, "Flora Brasiliensis" foi o estudo mais completo, realizado por Müeller (1873) com coletas próprias e análise do material botânico da missão de Von Martius e de outros renomados botânicos, identificando-se 271 espécies (Allem, 1978), com registro atual de 354 espécies (Webster, 1993).

O gênero Croton de acordo com Cronquist (1988), pertence à família Euphorbiaceae, ordem Euphorbiales, subclasse Rosidae, classe Magnoliopsida, das Magnoliophytas. Bremer et al. (1998) e APG (2003) de acordo a uma análise cladística reclassificaram as Euphorbiaceae dentro de Malphigiales sob uma sustentação monofilética, agrupando Euphorbiales a essa Ordem, que ademais pertence à taxa mais elevada das Eurosidas. A classificação e a diferenciação do gênero são extremamente 
controvertidas (Webster, 1993), pela grande diversidade no plano morfológico, citológico e anatômico. Exemplo, os estiletes bífidos contra multifidos, tricomas estrelados contra pêlos lepidotos ou, presença ou ausência de glândulas nas folhas, a conformação de tricomas. Esta última característica é uma das mais importantes por apresentar-se com freqüência e pela facilidade de observação, permitindo a definição de espécies e de taxas supraespecíficos (Webster et al., 1996).

Webster (1993) reclassificou as espécies do gênero Croton dividindo-as em 40 seções que, supostamente, refletem melhor os relacionamentos filogenéticos em relação a classificação de Müeller (1873), que é considerada muito artificial, por basear-se nas diferenças dos tipos de tricoma, presença de glândulas, estípulas e/ou sépalas, redução das pétalas, grau de ramificação dos estiletes e inflorescência sendo, no entanto, útil e funcional somente para as espécies do novo mundo.

O gênero Croton compreende árvores (10-20m de altura), arbustos, ervas semilenhosas ou ervas monóicas ou dióicas. Folhas simples, geralmente alternas, com 2 glândulas na base da lâmina ou no extremo dístal do pecíolo; dentadas, inteiras ou lobadas, cordadas ou subcordadas; com ou sem estípulas, persistentes ou caducas. Flores monóicas ou dióicas, axilares ou terminais; espiciformes ou racemosas (paniculadas ou subcapitadas), às vezes bracteadas; as flores pistiladas na parte basal ou misturadas com as estaminadas; flores estaminadas com várias brácteas; sépalas em regra 5, raras vêzes 4 ou 6 unidas, valvadas ou imbricadas; corola em geral com 5 pétalas ou ausente; disco anular ou partido em glândulas; androceu com estames centrais, em número de 5-50, filamentos livres, encurvados no botão; anteras basifixas, introrsas na ântese; flores pistiladas com 1 bráctea; sépalas 410 unidas, imbricadas ou valvares; corola com 5 pétalas ou ausente; disco anular ou formado por glândulas; pistilo em regra 3-locular, raro 2; óvulos 1 por lóculo, estiletes livres, indivisos ou bífidos a divididos sucessivamente. Fruto cápsula, $\operatorname{cocos} 3$; sementes lisas com carânculas pequenas (Smith \& Downs, 1959, Gentry, 1993 e Vásquez ,1997).

As plantas deste gênero crescem em uma grande variedade de habitats e de solos, encontram-se freqüentemente a beira dos rios e riachos e não se desenvolvem em 
áreas com inundações periódicas. Ocorrem em solos de origem aluvial, profundos ou medianamente profundos, com boa drenagem e não suportam períodos longos de inundações; com textura franco-arenoso, franco-limoso e franco-argilo-arenoso; de reação moderadamente ácida à ligeiramente alcalina (Forero et al., 2000 e Meza \& Pariona, 1999a).

Segundo Forero et al. (2000) as espécies deste gênero são de floresta tropical seca a muito úmida; com temperaturas médias anuais de $17,7-30{ }^{\circ} \mathrm{C}$ e precipitação de 600-4000 mm, que variam em função da altitude e latitude (Meza, 1999b e Forero et al., 2000).

Preferem os locais alterados, fragmentos de florestas e especialmente os campos de cultivo abandonados onde convertem-se em espécie pioneira (Meza \& Ayala,1998 e Nascimento et al., 1999). É umas das espécies mais importantes na dinâmica da sucessão florestal, chegando a predominar na floresta secundária até o $10^{\circ}$ ano (Hardesty et al., 1988; Hardesty \& Box, 1988; Metzger et al., 1998; Sampaio et al., 1998; Alburqueque, 1999; Gonçalves et al., 1999 e Nascimento et al., 1999). Na dinâmica da floresta, as áreas desmatadas com ou sem queima e as clareiras grandes sempre são ocupadas por exemplares de Cecropia sp., Ochroma pyramidale, Jacaranda copaia, Inga spp., Guazuma crinita, Miconia sp., Trema micrantha, Vernonia sp., Pouroma sp., etc., sendo o Croton que pelo geral possui maior valor ecológico no processo de recuperação da floresta (Kirmse et al., 1987; Schacht \& Malechek, 1990; Sampaio et al., 1993; Batista et al., 1996; Metzger et al., 1997 e Oliveira et al., 1997). As espécies de Croton, encontram-se no grupo das plantas pioneiras, necessitando de elevado nível de luz para a germinação das sementes, crescimento e estabelecimento (Botelho et al., 1996 e MoraesNeto et al., 2000). Em clareiras e diversos microclimas é possível verificá-la em todos os estágios da sucessão (Davide et al., 1996; Mariano et al., 1998; Alburqueque, 1999 e Silva \& Noriega, 1999) e contribuindo para melhorar o nível de fertilidade do solo para o posterior estabelecimento de outras espécies (Pagano, 1989; Vallilo,1998 e Vallilo \& Oliveira, 1999). 
A presença de plantas de Croton nos primeiros estágios da sucessão deve-se às suas estratégias fenológicas, de disseminação e de polinização, bem como as estruturas de atração (ex: nectários florais e extraflorais nas folhas) que secretam néctar na época da polinização e estão associadas a insetos, aves e mamíferos (Davis, 1945; Morellato \& Leitão-Filho, 1990; Passos \& Ferreira, 1996; Barth \& Da-Luz, 1998; Armbruster et al., 1999 e Ferraz et al., 1999).

\subsubsection{Importância florestal, medicinal e econômica}

As espécies do gênero Croton vêm despertando grande interesse pelas suas propriedades químicas e farmacológicas, comprovadas clinicamente como antinflamatória, cicatrizante, citoxidante, inibidor das células cancerígenas, antimicótica, antibacterial e antiviral e utilizada para inúmeras doenças (diarréias, úlceras intestinais, gastrites, faringites, herpes, hemorróidas, brotoeja, brônquios e para a cura do câncer e da AIDS) (Persinos et al., 1979; Vaiberg et al, 1989; Gudiño et al, 1991; Chen et al., 1994; Pieters \& De Bruyne, 1995; Málaga, 1991 e Miller et al., 2000).

O látex das espécies de Croton tem sido usado por séculos pelas comunidades indígenas da Amazônia como planta medicinal para várias enfermidades como antinflamatório, cicatrizante de feridas e analgésico bucal, para úlceras estomacais e diarréias (Neill, 1986 e Lescure et al., 1987). Os Huitotos, que vivem perto de LeticiaColômbia e Tabatinga-Brasil o utilizam nas feridas e nas chagas infectadas e em Manaus o látex de C. palanostigma Klotzsch é aplicado nas feridas e infecções da pele (Shultes \& Raffauf, 1990). Os Quíchuas da Amazônia equatoriana denominam C. lechleri Müll.Arg. como ian-iqui e usam- na para o tratamento do escorbuto das mucosas bucais ou da língua, limpeza dental, tratamento da anemia, enfermidades dos rins e estômago e como cicatrizante de feridas ou de cortes de faca (Kohn, 1992).

Várias espécies do gênero Croton apresentam importantes resultados nas pesquisas químicas, farmacológicas e clínicas (Primo, 1945; Gottlieb et al., 1978; Perdue et al., 1979; Craveiro \& Silveira, 1982; Aguiar et al., 1988; Itokawa et al., 1991; SouzaBrito \& Brito-Souza, 1993; Castillo-Cotillo et al., 1996; Ortega et al., 1996; Amaral \& 
Barnes, 1997; Moraes et al., 1997; Schultes, 1997; Capasso et al., 1998; Pereira et al., 1999 e Martins et al., 2000). De todas as espécies do C. lechleri, Persinos et al. (1979) logrou isolar um alcalóide denominado taspina (Pieters et al,. 1990; Cai et al., 1991e Carlin et al., 1996) com propriedades antiinflamatórias, para reumatismo e artrites (Neill, 1986). Vaisberg et al. (1989) comprovaram os efeitos cicatrizantes da taspina de $C$. lechleri "in vivo" com ratos, corroborando Pérez (1988), pelo efeito não carcinogénico ou estimulador tumoral, indicando ser uma planta medicinal altamente promissora. Ubillas et al. (1994) isolaram protoanthocianidina oligomérica (denominado SP-303) do látex de C. lechleri com potente atividade contra vírus DNA e RNA como as cepas de vírus respiratório cincinial (RSV), vírus A da influenza (FLU-A), vírus parainfluenza (PIV), herpesvírus (HSV) tipos 1 e 2 e hipervírus resistente aos fármacos acyclovir e foscarnet. Observou-se, também, a inibição contra os vírus da hepatite A e B e, nos animais de laboratório, a ausência de toxicidade. C. palanostigma tem os heterósidos, tanino, ácido benzoico e celulose. O látex (dracoresina) é constituído por ésteres de álcool resínico (dracopresinetanol), ácido benzoil acético, uma substância branca (draco albano) e resíduos vegetais (Pallar de Peralta, 1988), cujas ações principais são cicatrização, inflamação, inflamações dérmicas, reumatismo e úlceras gastroduodenais e como antiviral. Em Iquitos, Peru o látex de C. lechleri, C. draconoides Müll.Arg. e C. erythrochilus Müll.Arg. (Bettolo \& Scarpati, 1979) é empregado como cicatrizante da pele, nas úlceras estomacais e nas inflamações dos órgãos genitais femininos (Vázquez, 1992 e Miller et al., 2000). Na Colômbia, emprega-se o látex de C. funckianus Müll.Arg. na amebiase e para curar as úlceras duodenais (García- Barriga, 1975). Em Lima-Peru, o C. draconoides foi usada no tratamento de enfermidades tumorais (Schmitt, 1988); Croton nepetifolius Baill. demonstrou efeitos hipotensores em ratos (Lahlou et al., 1999). Hiruma-Lima et al. (2000) e Maciel et al. (1998 \& 2000) isolaram terpenos da casca de Croton cajucara Benth. e comprovaram sua eficiência nas desordens gastrointestinais, distúrbios renais, hepáticos e de colesterol (Faria et al., 1997). A casca dessa espécie é indicada para diarréias, diabetes e como agente antitumoral e anticancerígena (Kubo et al., 1991; Brito et al., 1998 e Grynber et al., 1999) e nos 
processos inflamatórios e analgésicos (Ichihara et al., 1992; Carvalho et al., 1996 e Bighetti et al., 1999). Hiruma-Lima et al. (2000) também comprovaram o efeito gastroprotetor do látex de Croton cajucara; as propriedades analgésica, antiflamatória, anti-reumática, antimicrobiana, antibiótica e anticancerígena de Croton urucurana Baill. são conhecidas no Brasil (Peres et al., 1997 \& 1998).

Outras espécies como $C$. antisyphiliticus Mart., $C$. draconoides e $C$. mucronifolius Müell.Arg. têm demonstrado ser amplamente potentes em doenças de transmissão sexual (sífilis e AIDS) (Lemos et al., 1992; Mahmood et al., 1993 e Santos \& Elisabetsky, 1999); C. draco Schltdl. neutraliza o efeito hemorrágico do veneno da cobra Bothrops asper Garman (Castro et al., 1999); na Guatemala o C. guatemalensis Lotsy é usado contra malária (Franssen et al., 1997).

Além da importância medicinal, C. matourensis Aubl. (Américo et al., 2002) e C. tessmanii Mansf. são indicadas para a fabricação de polpa para papel (Melo \& Hunh, 1974 e Scheuch \& Hidalgo-Lozano, 1993) e C. cajucara para óleos essenciais (Araújo et al., 1971).

\subsubsection{Anatomia do lenho}

Os estudos anatômicos do gênero estão restritos a poucas espécies, em geral de importância madeireira. Segundo Calvino (1958), a madeira destas plantas são classificadas em 2 grupos distintos, sendo o $1^{\circ}$ representado pelo lenho do $C$. floribundus e o $2^{\circ}$ por $C$. verrucosus Radcl.-Sm. \& Govaerts (antes C. echinocarpus Baill.), C. matourensis e $C$. salutaris Casar. e afins. A madeira do $1^{\circ}$ grupo distingue-se com relativa facilidade pela cor bege claro e pelo parênquima em nítidas linhas finas concêntricas e aproximadas, visíveis sob lente em seção transversal. A madeira do $2^{\circ}$ grupo tem cor branco palha, com parênquima paravascular se estendendo, predominantemente, em prolongamentos finos, longos e irregulares. Loureiro (1968) estudou a anatomia de lenho de Croton lanjouwensis (antes C. matourensis var. benthamianus Müll.Arg.) e C. matourensis revelando características muito semelhantes e diferenciadas apenas pelas dimensões dos vasos e dos raios. As características do 
parênquima axial apotraqueal e difuso coincidiram com a caracterização de Alcir et al. (1999).

\subsubsection{Distribuição geográfica}

Gênero cosmopolita, com o semiárido como o seu habitat mais típico e encontrado em quase todas as zonas de vida do mundo, como em praias de água salgada, desertos, florestas de nuvens, florestas úmidas tropicais, subtropicais e temperadas, florestas alagadas, etc. (Borhidi \& Muñiz, 1977).

Na América distribui-se nas regiões tropicais e subtropicais, desde o sul do México, passando pela América Central, Colômbia, Venezuela, Equador, Peru, Bolívia, Brasil, Paraguai, Uruguai e Argentina. É muito comum nas selvas baixas e nas montanhas até os 2.500 m (Ubillas et al., 1994; Bastien, 1991; Pinedo et al., 1997 e Meza \& Ayala, 1998).

\subsubsection{Situação populacional e conservação}

Nas espécies do gênero Croton, principalmente as denominadas sangue-degrado, deverá ocorrer um aumento da demanda do látex e casca quanto da confirmação clínica das propriedades anti-cancerígenas, antiflamatórias e cicatrizantes; além do presente mercado de produtos derivados e fabricados com o látex (sabonetes, cremes, óleos de beleza, etc.) (Forero et al., 2000). Atualmente nas áreas onde ocorrem vêm sendo submetidas a intensa atividade agropecuária (Wanderley et al., 1974), com as capoeiras não completando o seu ciclo e não permitindo a reprodução das plantas por sementes. A exploração clandestina do látex implica na morte das árvores de Croton, colocando-as sob risco de extinção e perda de sua diversidade genética (Forero et al., 2000). É necessário propor e aplicar um plano de manejo para as espécies de grande potencial medicinal, com a participação de instituições públicas e organizações civis, trabalhando com esse recurso sob uma fiscalização e monitoramento adequados, com sustentabilidade, como se pratica no Peru (Borges \& King, 2000). 


\subsection{O gênero Uncaria}

\subsubsection{Aspectos taxonômicos e ecológicos}

O gênero Uncaria, pertencente à família Rubiaceae apresenta 39-60 espécies distribuídas principalmente na África e Ásia (Obregón, 1995; Rea, 1995 e Steyermark, 1974). Na América ocorrem somente Uncaria guianensis (Aubl.) J.F. Gmel. e $U$. tomentosa (Willd. ex Roem. \& Schult.) DC. (Ramírez, 1992; Urrunaga, 1994 e Zavala \& Zevallos, 1996), sendo morfologicamente similares e, em geral, confundidas quando identificadas pelas características vegetativas (Zavala \& Zevallos, 1996), existindo, ainda, controvérsias na sua identidade pelo emprego incorreto e inadequado de termos botânicos.

O gênero Uncaria, de acordo com Cronquist (1988), pertence à família Rubiaceae, da ordem Rubiales, da subclasse Asteridae e classe Magnoliopsida, divisão Magnoliophyta. A família foi separada em função da classificação filogenética da ordem Gentianales pela classificação de A. Engle (Hutchinson, 1967) por apresentar ovário ínfero e bilocular. Segundo Rea (1995), em 1893, o gênero foi incluído na Tribo Cinchoneae, que agrupa aqueles com sementes com asas. Segundo Anderson (1994, 1995), em 1889, foi transferida para a Tribo Naucleeae reconhecida por muitos autores (Obregón, 1995; Rea, 1995; Zevallos et al., 2000; Sylvain \& Bremer, 2002) e, ultimamente, a Coptosapelteae, o que ocasiona confusão na classificação de toda a família. Bremer et al. (1998) e APG (2003) reclassificaram de acordo a uma análise cladística as Rubiaceae nas Gentianales sob uma sustentação monofilética, voltando à ordem original e pertencendo ao grupo mais elevado Euasteridas I.

Haviland (1898) destaca o fácil reconhecimento das espécies do gênero pelo hábito trepador e pedúnculos reduzidos a espinhos e curvados. Entretanto, Ridsdale (1972) relata a dificuldade de sua identificação, justificando os 120 sinômimos para as 39 espécies no mundo do "Index Kewensis". As características aplicadas na classificação das espécies são a presença de brácteas intra-florais, do pedicelo, do tamanho e forma do cálice e de seus lóbulos, da forma das estípulas, entre outras (Peña et al., 1998). 
As plantas das espécies do gênero são, em geral, arbustos trepadores, lianas trepadeiras e rasteiras ascendentes, com um par de espinhos enganchadores, originados de pedúnculos abortivos, subindo habitualmente até a copa das árvores. Têm folhas simples e opostas; lâmina ovada, elíptica, obovada ou oblonga, de consistência cartácea, papirácea ou finamente coriácea, pecíolos curtos ou longos. Com um par de estípulas interpeciolares, livres na base, deltóide, obovada ou cordada, caducas; seção da ramagem terminal quadrangular (Zavala \& Zevallos, 1996). Flores bissexuais ou funcionalmente unissexuais, em capítulos densos e globosos, axilares ou terminais de inflorescência do tipo panículas; hipanto fusiforme ou turbinado; cálice com 46 elementos, ovado ou estreitamente ovado, lóbulos curtos, valvares ou imbricados; corola hipocrateriforme ou estreitamente infundibuliforme, actinomorfa, branco-verdosa, creme, amarela ou laranja, geralmente pubescente por fora e glabra por dentro, lóbulos valvares; estames 5, insertos na garganta da corola, filetes curtos; anteras oblongas, coniventes, algumas vezes estéreis e não coniventes; disco inconspícuo; ovário fusiforme, 2-locular, estilete fino, exserto; placentação axilar. Estigma capituliforme, com numerosos óvulos ascendentes. Fruto cápsula alargada; 2-locular, deiscência septicida, válvulas bipartidas, endosperma carnoso, embrião craviforme, cotilédone pequeno e radícula obtusa. Sementes aladas, com margem inteira, dentada ou irregular (Steyermark, 1974; Gentry, 1993; Boom \& Delprete, 1994; Rea, 1995 e Zevallos et al., 2000).

São próprias de climas úmidos tropicais e subtropicais (Shunke, 1998), com temperaturas médias anuais de $17,0-25,7^{\circ} \mathrm{C}$ e precipitações médias anuais de $1200-4000$ mm suportando até 6000 mm (Zavala \& Zevallos, 1996 e Zevallos et al., 2000), com temperaturas e precipitações máximas no verão, em classes altitudinais de 0 a 1500 m (Villachica et al., 1998).

As espécies americanas desenvolvem-se em solos de origem coluvial ou aluvial de textura franca-arenosa ou franca-argilosa (Shunke, 1998), pH de fortemente ácido a ligeiramente alcalino, abundante matéria orgânica em áreas de má drenagem ou alagadas (Flores-Bendezú, 1995a \& 1995b e Zevallos et al., 2000). 
Segundo Quevedo (1995), U. guianensis é uma espécie considerada heliófita efêmera e invasora de capoeiras de vegetação arbustiva e com alta capacidade de autoregeneração natural. Geralmente os caules das lianas são mais rasteiros do que os das trepadeiras pelo espinho em forma de corno, com ponta dobrada para o interior a diferença de $U$. tomentosa, heliófita durável, exclusivamente trepadeira pela forma dos espinhos semi-curvados que facilitam a sua aderência a casca e galhos das árvores até chegar as suas copas (Zavala \& Zevallos, 1996).

\subsubsection{Importância florestal, medicinal e econômica}

Por mais de 2000 anos os povos amazônicos, em especial os Ashaninka, têm usado a unha de gato (U. guianensis e U. tomentosa) para a cura de várias enfermidades (inflamações gerais, gastrites, ulceras, diarréias, certos tipos de tumores, artrites, reumatismo, acne, diabetes, doenças do tracto urinário, gonorréia e câncer), sendo muitas vêzes misturada com a casca de outras plantas para uso como abortivo, como o chuchuhuasi (Maytenus spp) (Zevallos et al., 2000). Esse conhecimento ancestral das comunidades indígenas no uso das plantas da espécies do gênero Uncaria é corroborado pelos resultados das pesquisas e estudos da composição química das partes dessas

plantas, que mostraram a presença de metabólitos secundários de grande interesse e utilidade na medicina e na indústria farmacêutica (Keplinger et al., 1999).

Plantas do gênero Uncaria são usadas na América como estimulantes do sistema imunológico e remédio eficaz contra o câncer. As espécies apresentam mecanismos de ação intra e extra-celular de tipo antinflamatório, inibidor das mitoses celulares, incremento dos granulócitos e macrófagos, supressão da implantação de células tumorais, inibição da proliferação celular e incremento da fagocitose dos macrófagos, sendo usada em infecções virais tais como a AIDS (Urrunaga, 1994 e Keplinger et al., 1999). Entre outras propriedades estão as atividades anticonceptivas (Ramírez, 1992 e TCA, 1995) e afrodisíacas (IPSS, 1997). Lock de Ugaz (1994) afirmou que as espécies do gênero podem ser usadas nas gastrites, inflamações e inibições do crescimento de tumores. As 2 espécies de Uncaria têm propriedades energéticas e/ou 
nutritivas; o extrativista em condições duras e estressantes (alto calor e umidade das florestas) utiliza a seiva de unha de gato como energético (Cabieses, 1997).

Estudos bioquímicos têm apontado mais de 60 alcalóides oxindólicos (Matta et al., 1976), que variam marcadamente entre as diferentes espécies de Uncaria (Hemingway \& Phillipson, 1992; Stuppner et al., 1992; Laus et al., 1997 e Zevallos et al., 2000). Os alcalóides de cada planta podem variar de 10-40, dependendo do solo, clima, associação vegetal e genética da planta e, no caso de plantação, das técnicas de manejo da cultura e da colheita. (Kam et al., 1992; Quevedo, 1995 e Zevallos et al., 2000). Em U. tomentosa outros estudos têm identificado 2 tipos de componentes químicos (um contém alcalóides pentacíclicos imuno-estimulante) e em U. guianensis antagonicamente alcalóides tetracíclicos que atuam sobre o sistema central nervoso (Harada et al., 1974 e Reihnard, 1999), com aparente atividade anti-leucêmica (Stuppner et al., 1992) e de estimulação da atividade de fagositose in vitro (Wagner et al., 1985).

A casca de $U$. tomentosa contém triterpenos polihidroxilatedo (saponinas triterpenoides) de efeitos anti-tumorais carcinoma-Ehrlich (Nagamoto, 1988), esteróides (sitosterol Beta, stigmasterol e campesterol) suaves inibidores da síntese do colesterol (Field et al., 1997) e moderado antiflamatório (Senatore et al., 1989), taninos para feridas e soriase, 7 glicósidos do ácido quinóvico (QAG's) (Aquino et al., 1989) com função antiflamatória (Aquino et al., 1991). Em U. guianensis os flavonóides são antioxidantes (Yépez et al., 1991 e Villachica et al., 1998); proanthrocianidina são antioxidantes incluídos no gênero (Matta et al., 1976).

A indústria de medicamentos naturais, em função das pesquisas do gênero Uncaria, já está fabricando medicamentos para tratar doenças cardiovasculares (hipertensão e hipercolesterolemia) (Wang, 1989 e Huang, 1999) renais (inflamações do trato urinário), ginecológicas (inflamações da vagina, útero e ovários), gastrointestinais e hepáticas (ulceras, gastrites, cirrose hepática), endócrinas (diabetes), reumatológica (artrite e artrose), reprodutiva (contraconcepção e abortivo) (Keplinger, 1982), imune estimulante (estimula o sistema imunológico e como antiflamatório) (Wagner et al., 1985; Aquino et al., 1991 e Duke \& Vásquez, 1994); antimicrobiano e antiviral (os 
ácidos quinóvicos têm atividade antiviral) (Cerri, 1988 e Aquino et al., 1989) sobretudo nos caso de pacientes de AIDS, anti-neoplástica, nos casos de leucemia e câncer (Moss, 1998 e Sheng et al., 1998); antioxidante, aumentando a resistência dos tecidos (Desmarchelier et al., 1997).

\subsubsection{Anatomia do lenho}

Os estudos anatômicos das espécies americanas deste gênero se concentram na casca e muito pouco na madeira (Silva et al., 1998). Zevallos et al. (2002), trabalhando com material lenhoso de $U$. guianensis e $U$. tomentosa do Peru, encontraram que a estrutura anatômica macroscópica do lenho das espécies era muito semelhante, ressaltando, em nível microscópico os raios unisseriados e multisseriados, respectivamente. Silva et al. (1998) encontraram raios uni e multisseriados no lenho de U. tomentosa.

\subsubsection{Distribuição geográfica}

As espécies do gênero encontram-se amplamente distribuídas na África, Ásia e América. Nas regiões tropicais e subtropicais da América $\left(13^{\circ} \mathrm{N}-13^{\circ} \mathrm{S}\right)$ são reportadas $U$. guianensis e $U$. tomentosa que, Villachica et al. (1998), supõem ser o centro de origem amazônico, desde a Guatemala, passando por Belize, Honduras, El Salvador, Nicarágua, Costa Rica, Panamá; também encontrando-se na Colômbia, Venezuela, Guiana, Equador, Peru, Bolívia e Brasil, na bacia do Amazonas (Zevallos et al., 2000).

Brako \& Zaruchi (1993) registram a presença das espécies de Uncaria de 0-600 m; Domínguez-Torrejón (1997) encontrou-as na selva peruana a partir de 75 m; Zavala \& Zevallos (1996) reportam U. tomentosa entre os 300-900 m e segundo Villachica et al. (1998) são espécies heliófitas, com extensão de adaptação de altitude de 0-1500 m.

\subsubsection{Situação populaciona l e conservação}

O trabalho de Zavala \& Zevallos (1996) apresenta uma primeira aproximação sobre o diagnóstico das populações das espécies de Uncaria, usando metodologia da 
"IUCN" (1998), classificando-as como em situação de perigo (vulnerabilidade que implica em redução drástica de populações eliminadas por madeireiros e para a ampliação da fronteira agropecuária).

Nas áreas de capoeiras, estradas, bordas de rodovias é comum serem encontradas plantas de $U$. guianensis consideradas como daninhas e submetidas a práticas de limpeza severa pela aplicação de agrotóxicos e de queima, eliminando-as completamente (Sosa \& Medrano, 1992).

$\mathrm{Na}$ atualidade, a unha de gato (Uncaria guianensis e U. tomentosa) tem significativa importância pelas substâncias presentes na sua casca e pelas propriedades farmacológicas (cura do câncer e AIDS), provocando intensa procura pelos laboratórios e herbolários e com o Peru exportando 726 ton de casca e de raiz em 1996 (Jong et al., 1999).

A casca e a raiz exploradas intensamente e de forma indiscriminada nas florestas naturais, induziu uma forte pressão para a regularização e fiscalização das florestas nativas, com o seu manejo e implantação de novas plantações (Flores-Bendezú, 1995b e Zevallos et al., 2000). No Brasil a EMBRAPA-Acre segundo Melo et al. (2001) vem realizando o monitoramento da exploração e do manejo nas áreas de Reservas Indígenas, para que o seu aproveitamento esteja de acordo com os critérios de sustentabilidade. 


\section{MATERIAL E MÉTODOS}

\subsection{Revisão de herbários, bibliotecas e "sites"}

A revisão das exsicatas das espécies dos gêneros Cinchona, Croton e Uncaria foi conduzida em Herbários de instituções nacionais e internacionais. As análises das exsicatas foram direcionadas para os materiais botânicos coletados na área de ocorrência natural das espécies ou próximas desta, complementadas com as informações contidas nas etiquetas de identificação, referentes a distribuição geográfica e situação das populações das espécies dos 3 gêneros.

Os herbários nacionais e internacionais selecionados para a análise das exsicatas das espécies são relacionados na Tabela 1.

Tabela 1. Herbários nacionais e internacionais

\begin{tabular}{|c|c|c|c|}
\hline Estado/país & Cidade & Sigla & Denominação/instituição \\
\hline \multicolumn{4}{|c|}{ Herbários nacionais } \\
\hline \multirow[t]{2}{*}{ Acre } & Rio Branco & HPZ & Parque Zoobotânico \\
\hline & & & Universidade Federal do Acre \\
\hline \multirow[t]{2}{*}{ Amazonas } & Manaus & INPA & Instituto Nacional de Pesquisas da Amazônia \\
\hline & & & Ministério da Ciência e Tecnologia \\
\hline \multirow[t]{4}{*}{ Pará } & Belém & MG & Museu Paraense Emílio Goeldi \\
\hline & & & Ministério da Ciência e Tecnologia \\
\hline & & IAN & EMBRAPA Amazônia Oriental \\
\hline & & & Ministério da Agricultura e Abastecimento \\
\hline \multirow{2}{*}{\multicolumn{3}{|c|}{ Rio de Janeiro Rio de Janeiro R }} & Museu Nacional do Rio de Janeiro \\
\hline & & & Universidade Federal do Rio de Janeiro \\
\hline & & $\mathrm{RB}$ & Jardim Botânico do Rio de Janeiro \\
\hline & & & Ministério do Meio Ambiente \\
\hline
\end{tabular}


Tabela 1. Herbários nacionais e internacionais (continuação)

\begin{tabular}{|c|c|c|c|}
\hline Estado/país & Cidade & Sigla & Denominação/institução \\
\hline \multirow[t]{14}{*}{$\overline{\text { São Paulo }}$} & Botucatu & UNBA & Departamento de Botânica \\
\hline & & & Universidade Estadual Paulista \\
\hline & Campinas & UEC & Instituto de Biologia \\
\hline & & & Universidade Estadual de Campinas \\
\hline & Piracicaba & ESA & Departamento de Ciências Biológicas \\
\hline & & & ESALQ/Universidade de São Paulo \\
\hline & Rio Claro & HRCB & Herbário Rioclarense \\
\hline & & & Universidade Estadual Paulista \\
\hline & São Paulo & SPF & Instituto de Biociências \\
\hline & & & Universidade de São Paulo \\
\hline & & $\mathrm{SP}$ & Instituto de Botânica de São Paulo \\
\hline & & & Secretaria de Estado do Meio Ambiente \\
\hline & & SPSF & Instituto Florestal do Estado de São Paulo \\
\hline & & & Secretaria de Estado do Meio Ambiente \\
\hline \multicolumn{4}{|c|}{ Herbários internacionais } \\
\hline \multirow[t]{2}{*}{ Bolívia } & La Paz & LPB & Nacional de Bolívia \\
\hline & & & Universidad Mayor de San Andrés \\
\hline \multirow[t]{6}{*}{ Peru } & Iquitos & AMAZ & Herbário Amazonense \\
\hline & & & Universidad Nac.de la Amazonia Peruana \\
\hline & Lima & MOL & Herbário Weberbauer \\
\hline & & & Universidad Nacional Agraria-La Molina \\
\hline & & USM & Museo de Historia Natural Javier Prado \\
\hline & & & Universidad Nacional Mayor de San Marcos \\
\hline
\end{tabular}

Nos herbários relacionados foram realizadas, também, revisões mas bibliotecas especializadas existentes sobre aspectos da botânica, dendrologia e anatomia do lenho das espécies dos 3 gêneros. 
Posteriormente, conduziu-se uma revisão nos principais "sites" da Internet da bibliografia existente com destaque para Base de dados $\mathrm{W}^{3}$ TROPICOS Missouri Botanical Garden: www.mobot.org; Link NYBG New York Botanical Garden: www.nybg.org; International Plant Name Index Query: www; us.ipni.orgus.ipni.org; Flora Brasilensis: www.cria.org.br.

\subsection{Amostragem de campo}

A amostragem de campo compreendeu a maioria dos municípios do Estado do Acre considerando a acessibilidade, a probabilidade de localizar as espécies de interesse fundamentada na revisão dos materiais dos herbários, consulta bibliográfica e de informações coletadas dos moradores locais. Desta forma a área de amostragem envolveu 18 municípios acreanos, sendo Acrelândia, Assis Brasil, Brasiléia, Bujari, Capixaba, Cruzeiro do Sul, Epitaceolândia, Feijó, Mâncio Lima, Manoel Urbano, Plácido de Castro, Porto Walter, Rio Branco, Rodrigues Alves, Senador Guiomard, Sena Madureira, Tarauacá e Xapuri [Figura 1 e Tabela 2 (Anexo B)].

\subsection{Coleta e observações do material botânico}

O material botânico coletado consistiu de ramos terminais, preferencialmente férteis, com 6 repetições e do lenho das árvores através de corpos de prova $\left(1,5 \mathrm{~cm}^{3}\right)$, com 10 repetições. Ainda, em condições de campo, realizou-se o preenchimento de formulário sobre a descrição dendrológica considerando as características mais importantes dos exemplares das espécies, incluindo as informações sobre o grupo ecológico e dados sobre a regeneração natural (Anexo A).

Os equipamentos e recursos utilizados consistiram de prensas, cordas, correias, tesouras de poda e telescópica, saco plástico, cadernetas, lápis, câmara fotográfica digital, etc. Os trabalhos de campo tiveram guias locais com experiência na atividade agropecuária e florestal e que informaram o nome regional e usos das espécies coletadas. 
(a)

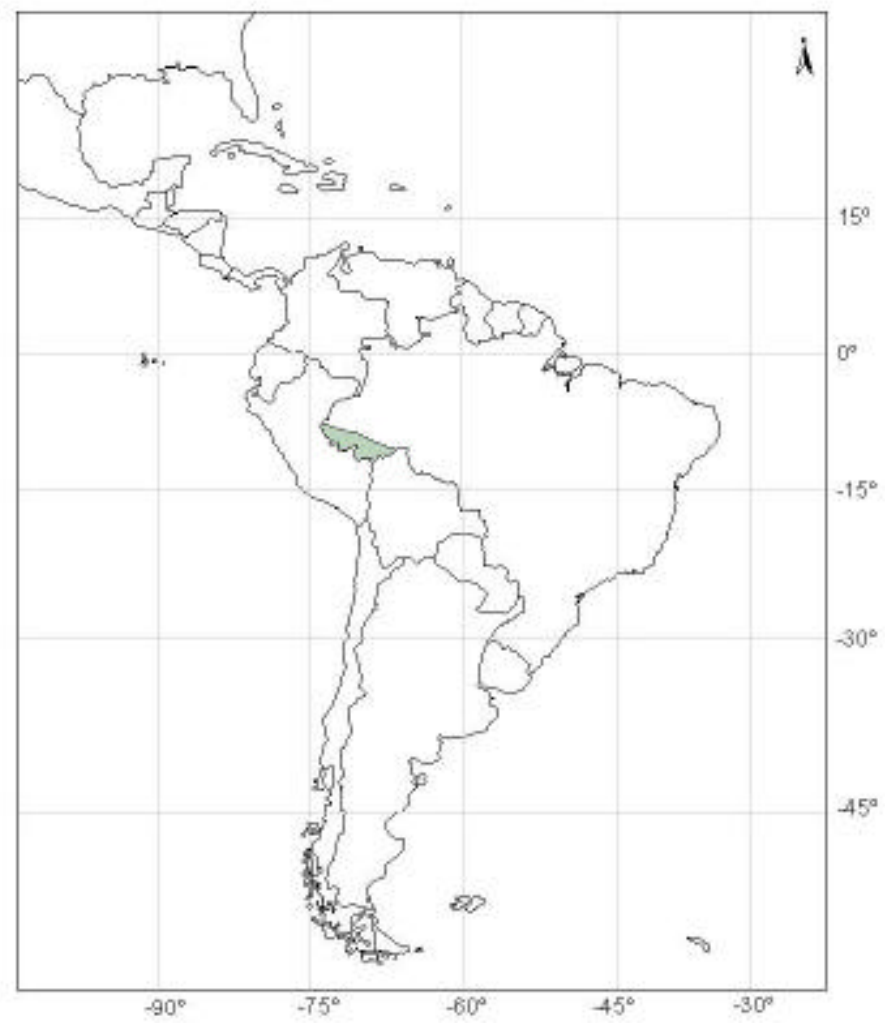

(b)

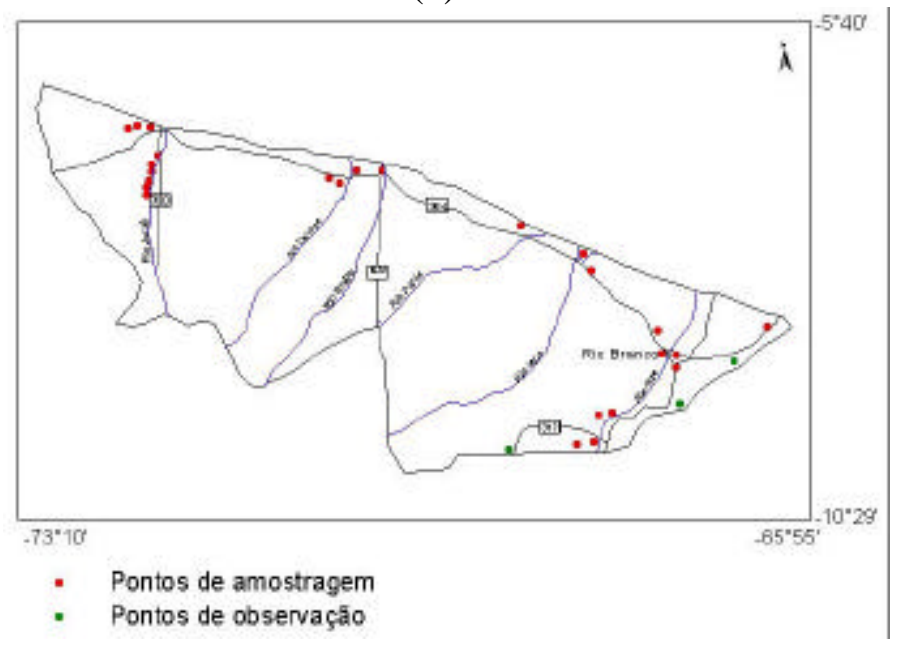

Figura 1- Localização geográfica do Estado do Acre no Brasil e na América Latina (a) e dos pontos de amostragem e de observação no Estado do Acre (b) 
Os espécimes botânicos coletados foram impregnados com uma solução composta de 1 parte de água e 4 de álcool 80\%, dispostos em papel de jornal duplo, com uma etiqueta de coleção e prensados entre folhas de papelão corrugado. As amostras botânicas no início foram secas sob radiação solar e, posteriormente, em secador elétrico do Herbário do Parque Zoobotânico da Universidade Federal do Acre-HPZ. Os segmentos de lenho foram secos ao ar para evitar as manchas provocadas por fungos e, em seguida, cortados nas dimensões de $1,5 \times 1,5 \times 1,5 \mathrm{~cm}$, para transporte ao Laboratório de Dendrologia, Anatomia e Identificação de Madeiras da ESALQ/USP, em Piracicaba, SP.

\subsection{Identificação taxonômica}

A determinação botânica das coletas botânicas foi realizada de acordo com a metodologia de Radford (1974), descrita por Zavala \& Zevallos (1996), que consiste no (i) uso de chaves de identificação dos gêneros Cinchona, Croton e Uncaria; (ii) uso de bibliografia especializada, como Índex floras, flórulas, monografias, catálogos, manuais, dicionários, etc.; (iii) comparação de coleta com os herbários especializados e (iv) envio ou consulta aos especialistas botânicos das amostras botânicas não identificadas.

\subsection{Caracterização e ilustrações das espécies}

A caracterização dendrológica das espécies foi feita a partir das observações dos exemplares no campo e dos materiais botânicos coletados. As ilustrações foram feitas em papel crayon em tamanho original e em estereomicroscópio com câmara clara, observando os detalhes dos pêlos das folhas e órgãos reprodutivos de importância na definição taxonômica. Nas características e ilustrações das espécies foram considerados os aspectos gerais (hábito, ramificação, tronco, base de tronco, raízes, diâmetro e altura); casca (cor, odor, sabor, ritidoma, exsudado); folha (tipos, formas, ápice, base, nervuras, estípulas, glândulas); inflorescência (tipo, tamanho, diâmetro); flores (cálice, corola, androceu e gineceu); frutos (tipo, forma, cor, consistência, deiscência); sementes (tamanho, presença de testa, viabilidade). 


\subsection{Caracterização do lenho}

\subsubsection{Maceração}

As análises morfológicas e a determinação das dimensões das células do xilema foram conduzidas após a maceração do lenho através do método do ácido acético-água oxigenada, constituindo no (i) preparo de finas lascas do lenho; (ii) transferência para tubos de ensaio com água destilada; (iii) substituição da água dos tubos pela solução macerante (ácido acético glacial e água oxigenada 120 vol, 1:1), (iv) transferência dos tubos perfeitamente fechados para estufa a $60^{\circ} \mathrm{C}$ por 48 horas; (v) retirada da solução macerante, lavagem do material macerado e sua armazenagem (Johansen, 1940 e Sass, 1951).

\subsubsection{Polimento das seções de estudo}

O polimento da superfície dos corpos de prova do lenho foi feito em um micrótomo de deslize pelo (i) preparo dos 3 planos de estudo através da orientação dos elementos anatômicos; (ii) corte da superfície dos 3 planos de estudo com navalha do micrótomo; (iii) polimento da superfície dos planos pelo atrito em pedra de afiação de granulação fina previamente umedecida em água; (iv) limpeza das 3 superfícies polidas dos corpos de prova com tecido macio e (v) análise da estrutura anatômica macroscópica do lenho.

\subsubsection{Avaliação das dimensões das células do lenho}

O estudo das características (forma e dimensão) das células do lenho consistiu na (i) transferência das células dissociadas no processo de maceração para lâmina histológica; (ii) adição de gota de safranina na lâmina e mistura com glicerina; (iii) observação das lâminas sob microscópio e/ou microscópio com projetor de fibras, (iv) avaliação do comprimento e diâmetro dos elementos anatômicos lenhosos no projetor de fibras; (v) avaliação da largura, espessura da parede e diâmetro do lume das células sob microscópio. 


\subsubsection{Prepa ro e montagem das lâminas histológicas}

As lâminas histológicas para a avaliação da estrutura microscópica do lenho foram obtidas pela (i) preparação dos blocos de madeira nos 3 planos de estudo através da orientação dos elementos anatômicos; (ii) amolecimento dos blocos de madeira em água em ebulição por 2 dias; (iii) cortes histológicos dos 3 planos com a espessura de 12-14 $\mu \mathrm{m}$; (iv) armazenamento dos cortes histológicos entre lâminas histológicas e papel metálico; (v) clarificação dos cortes histológicos com água sanitária e água destilada (1:1); lavagem dos cortes histológicos em água destilada; (vi) desidratação dos cortes histológicos em álcool (30/50\%); (vii) coloração com safranina astra-blue (30/70\%); (viii) desidratação em uma série alcóolica (50/100\%) e de acetato e álcool (1:1) e, acetato de N-Butila; (ix) seleção dos melhores cortes e montagem em lâmina de vidro com bálsamo de Canadá com uma lamínula (Johansen, 1940 e Sass, 1951).

\subsubsection{Descrição anatômica do lenho}

A descrição da anatomia do lenho das espécies dos 3 gêneros foi conduzida de acordo as normas da Comissão Pan-Americana de Normas Técnicas-COPANT (1974), IAWA-"List of microscopic feature for hardwood identification" (IAWA-Committee, 1989) e as Normas e procedimentos em estudos da anatomia da madeira (IBAMA, 1992).

\subsection{Distribuição geográfica}

As informações referentes a distribuição geográfica das espécies dos 3 gêneros foram obtidas através das revisões das exsicatas nos herbários, das fontes bibliográficas, das coleções e de outras observações realizadas nas áreas visitadas no Estado do Acre. Cada espécie foi indicada em um mapa do Brasil e da América Latina usando o programa ARC-View-GTS (Sistema de Informação Geográfica) e categorizadas de acordo com adaptações das normas da União Internacional para a Conservação da Natureza (IUCN, 1998), sendo: 
3.7.1 Critérios geográficos: latitude (limites de ocorrência de cada espécie em graus sexagesimais ${ }^{\circ} \mathrm{S}$ em relação a linha equatorial); longitude (limites de ocorrência de cada espécie em graus sexagesimais ${ }^{\circ} \mathrm{S}$ em relação ao Meridiano de Groenwich); altitude (limites de ocorrência de cada espécie em metros acima do nível do mar).

3.7.2 Critérios de localização: confinidade (espécies que ocorrem em âmbitos latitudinais não maiores do que $2^{\circ}$ sexagesimais ou uma variação de altitude não maior do que $100 \mathrm{~m}$ ) e endemismo (espécies exclusivamente ou quase que exclusivamente restrita ao Estado do Acre).

3.7.3 Distribuição particular: espécies concentradas em forma de ilhas bastantes afastadas entre si.

\subsection{Status de conservação ou situação populacional}

Determinou-se de acordo com a metodologia proposta pelo "Centro de Datos para la Conservación” (CDC, 1991) e pela União Internacional para a Conservação da Natureza (UICN, 1998 \& 2002), descritos a seguir:

3.8.1 Abundância no campo: espécies com ocorrência em toda a área de estudo e observações diretas realizadas durante as viagens de coleta. A coleta foi realizada em locais anteriormente visitados por outros pesquisadores e também em localidades indicadas na bibliografia ou verbalmente por nativos e/ou colonos.

3.8.2 Idade das coleções: considerou-se a idade das coleções dos herbários consultados no Brasil e no exterior.

3.8.3 Posição em áreas expostas: pela conferência do mapa de distribuição geográfica em diferentes coletas incluindo as informações dos herbários, da bibliografia e das 
coletas realizadas comprovando-se, desta forma, as alterações ou mudanças de localização.

3.8.4 Confinidade: pelo estudo da distribuição geográfica da espécie localizada em áreas relativamente pequenas na zona de estudo e que as indicam como em situação mais exposta.

3.8.5 Endemismo: ocorrência de uma espécie restrita quase que exclusivamente ao Estado do Acre, considerando (i) espécies totalmente endêmicas (com distribuição limitada exclusivamente ao território acreano) e (ii) espécies substancialmente endêmicas (com mais de $70 \%$ dos registros ou ocorrências no território acreano e os restantes em áreas adjacentes e não distantes em mais do que $04^{\circ}$ sexagesimais das fronteiras estaduais).

3.8.6 Proteção: espécies que em diferentes intensidade encontram-se protegidas pelo "Sistema Nacional de Unidades de Conservação do Acre"

3.8.7 Categoria: em função desses resultados determinou-se o status de conservação ou situação populacional, sendo extinto $(\mathrm{EX})$ quando não se tem dúvida alguma de que o último indivíduo está morto; extinto no estado silvestre (EW) quando só sobrevive em cultivo, em cativeiro ou como população naturalizada totalmente fora de sua distribuição original; em perigo crítico (CR) quando enfrenta risco extremadamente alto de extinção em estado silvestre em um futuro imediato; em perigo (EN) quando, não estando em perigo crítico, enfrenta de todas formas um alto risco de extinção ou deterioração populacional em estado silvestre em um futuro próximo; vulnerável (VU) quando, não estando nem em perigo crítico nem em perigo, enfrenta de todas formas um moderado risco de extinção ou deterioração populacional a médio prazo; quase ameaçada (NT) quando não satisfaz nenhum dos critérios para as categorias em perigo crítico ou em perigo ou vulnerável, mas pode se qualificar como vulnerável ou entrar nessa categoria 
em um futuro próximo; preocupação menor (LC) quando não qualifica para nenhuma das categorias anteriormente expostas, geralmente é usado para organismos muito comuns ou abundantes e eqüivale à fora de perigo; dados insuficientes (DD) quando a informação disponível é inadequada para fazer uma avaliação direta ou indireta de seu risco de extinção, com base na distribuição e/ou estado da população; não avaliado (NE) quando ainda não foi confrontado contra os critérios da UICN (1998 \& 2002). 


\section{RESULTADOS}

\subsection{Cinchona amazonica Standl.}

Família botânica: Rubiaceae

Publicado em: Publications of the Field Columbian Museum, Botanical Series 8(5): 334. 1931.

Tipo: Peru: Loreto: on the Amazon River in forest, 24 Jul 1929, Llewelyn Williams 1747 (HT: F 604562)

Sinônimo botânico: Cinchonopsis amazonica (Standl.) L. Andersson \{Ann. Missouri Bot. Gard.: 82(3): 424. 1995 \}

Nome vulgar: não apresenta

\subsubsection{Caracterização dendrológica}

Árvore pelo geral semi-tolerante a luz, mais de $15 \mathrm{~m}$ de altura, $18-40 \mathrm{~cm}$ de diâmetro; copa grande e bifurcada; fuste cilíndrico; casca externa marrom-bege, com manchas verdes escuras, aparentemente fissurada, ritidoma não evidente; casca interna vermelha clara a rosa-amarelo, de textura fibro-arenoso. Ramos terminais de seção cilíndrica ou semi-quadrada de até $10 \mathrm{~mm}$ de diâmetro, verde-marrom a marrom claro; folhinhas terminais em forma de lança; glabras ou presença de pêlos quando é pequena, densamente hirsutos, bege a verde-bege; o caule quando seco pode ser oco. Folhas simples, opostas e semi-cruzadas; abovada, elíptica-oblonga ou elíptica; de 14-27 cm de comprimento e 5-12 cm de largura; borda ou margem inteira a ligeiramente sinuosa; ápice obtuso; base atenuada, aguda redonda a aguda; nervura pinatinerva oblíqua, com 14-15 pares de nervuras; de consistência cartácea a coriácea; cor na parte abaxial verde escuro e adaxial verde claro brilhante; pêlos na parte abaxial nas axilas das nervuras, finos, retos e densos; pecíolo de 3-6,5 cm de comprimento e até $5 \mathrm{~mm}$ de diâmetro; 1 par de estípulas interpeciolares, de forma abovada, coriácea, caducas, deixando uma cicatriz 
conspícua nas ramas terminais; as folhas novas pelo geral maiores e com abundantes pêlos. Inflorescências terminais, do tipo panículas, grandes, de até $50 \mathrm{~cm}$ de comprimento; com caule marrom a marrom claro, com pêlos levemente densos e curtos. Flores bissexuais, medianas de até $3 \mathrm{~cm}$ de comprimento; apresentam brácteas de até 5$6 \mathrm{~mm}$ de comprimento, com pêlos curtos e hirsutos, densos na superfície adaxial e raros na abaxial; apresentam coléteres de cor marrom quando secos na base da superfície adaxial, acompanhados com pêlos longos, finos e densos, ocupando uma terceira parte; com hipanto com cálice adnato de até $6 \mathrm{~mm}$ de comprimento; cálice persistente, gamosépalo, cilíndrico, com 5 lóbulos; tubo de $0,5 \mathrm{~mm}$ de comprimento, bordo de até 0,5 mm de comprimento, com pêlos medianamente densos em toda a superfície; corola hipocrateriforme ou infundibuliforme, com 5 lóbulos alongados, com pêlos muito curtos e finos em toda a superfície, reflexos, agudos; tubo de até $9 \mathrm{~mm}$ de comprimento, esbranquiçado, com a base ligeiramente escura, bordo de até $10 \mathrm{~mm}$ de comprimento, branco ou amarelo; androceu com 5 estames adnatos à base da corola, com filamentos curtos de 3-3,5 mm de comprimento, com anteras bitecas, dorsifixas e deiscência longitudinal; gineceu com ovário ínfero, 2-carpelar, 2-locular, placentação axilar, presença de disco contínuo e em forma de taça, estilo terminal com terete de 8-10 mm de comprimento e estigma bífido de $1,5 \mathrm{~mm}$ cada. Fruto seco tipo cápsula, cilíndrico alongado, com 2 valvas de $3-8 \mathrm{~cm}$ de comprimento e $3-6 \mathrm{~mm}$ de largura cada, geralmente com baixa densidade de pêlos mais ou menos curtos, deiscência longitudinal, abrindo-se da base até o ápice. Sementes aladas de 1-2 cm de comprimento e 3-4 mm de largura (Figuras 2 e 3).

\subsubsection{Caracterização anatômica do lenho}

Cerne distinto do alburno e de cor amarelada a pardo-amarelada, brilho moderado, odor imperceptível, gosto levemente amargo, densidade de massa média, resistência ao corte moderadamente dura, grã direita, textura média. Camadas de crescimento pouco distintas, demarcadas pela espessura da parede celular das fibras.

Vasos visíveis a olho nu ou lente (10x); difusos; arranjo radial; solitários $(59,52 \%)$ e múltiplos $(40,48 \%)$ em grupos de 2,3 ou 4, freqüência $14-18 / \mathrm{mm}^{2}$; diâmetro tangencial 
do lume 66,65-119,97 $\mu \mathrm{m}$, média $81.31 \mu \mathrm{m}$ e desvio padrão 20,31 e forma arredondada; comprimento 666,50-1.599,60 $\mu \mathrm{m}$, média 1001,06 $\mu \mathrm{m}$ e desvio padrão 292,6; apêndice curto, menor a 1/3 do comprimento do vaso e em ambas extremos; placas de perfuração simples; depósitos indistintos; pontoações intervasculares areoladas, alternas, arredondadas, abundantes, ornamentação ausente, diâmetro tangencial 4,08-8,56 $\mu \mathrm{m}$, média $5,05 \mu \mathrm{m}$ e desvio padrão 0,61 ; pontoações raio-vasculares areoladas, alternas, arredondadas, abundantes, diâmetro tangencial 2,65-5,05 $\mu \mathrm{m}$, média de 4,01 $\mu \mathrm{m}$ e desvio padrão de 0,40; pontoações parênquimo-vasculares semelhantes às intervasculares. Fibras com pontoações distintamente areoladas maiores de $3 \mu \mathrm{m}$; curtas a longas, comprimento 1.240-1.690 $\mu \mathrm{m}$, média $1520 \mu \mathrm{m}$ e desvio padrão 160; largura média 28,13-46,88 $\mu \mathrm{m}$; espessura da parede delgada com lume de 12,25-25,00 $\mu \mathrm{m}$; pontoações alternas, arredondadas, abundantes na seção radial e tangencial, com diâmetro tangencial 2,56-5,87 $\mu \mathrm{m}$, média 4,74 $\mu \mathrm{m}$ e desvio padrão 0,60. Parênquima axial invisível a olho nu e distinto sob lente (10x); paratraqueal escasso ou unilateral; células do tipo seriado. Parênquima radial (raios) visível sob lente (10x), unisseriados $(45,45 \%)$ e multisseriados (54,55\%), com 2 séries raro 3; altura 4,99-9,76 mm, média 7,10 $\mathrm{mm}$ e desvio padrão 1,53; freqüência 3-9/mm, média $6 / \mathrm{mm}$ e desvio padrão 2,16; heterocelulares, com 4 fileiras $(23,46 \%)$ de células eretas na extremidade superior, no centro 9 fileiras $(53,09 \%)$ de células procumbentes e 4 fileiras $(23,46 \%)$ de células eretas na extremidade inferior; com 9-19 linhas de células; largura variando de 20,00-53,32 $\mu \mathrm{m}$. [Tabela 3 (Anexo B) e Figura 4].

\subsubsection{Distribuição geográfica}

Esta espécie se encontra distribuída nas vertentes da bacia Amazônica, podendo ser encontrada entre as faixas latitudinais $\left(03^{\circ} 10^{\prime} 00^{\prime \prime} \mathrm{N}-13^{\circ} 17^{\prime} 00^{\prime \prime} \mathrm{S}\right)$, longitudinais (5316'00”W-75²8”00”W) e altitudinais (70-1970 m) [Tabela 4 (Anexo B)]. Na América sua área de distribuição é relativamente ampla e encontra-se no Brasil, Colômbia e Peru, sendo no Brasil nos Estados do Acre, Amazonas, Pará e Roraima. No Acre nos municípios de Cruzeiro do Sul, Mâncio Lima, Rio Branco e Sena Madureira 
(Figura 5). Obedece a uma distribuição particular, sempre concentrada em locais de solos arenosos e bem drenados.

\subsubsection{Status ou situação populacional}

Esta espécie foi incluída na categoria CR (perigo crítico), pelo fato de ter uma distribuição particular. As populações ainda existentes estão sendo eliminadas para uso como madeira e para a ampliação da fronteira agropecuária [Tabela 7 (Anexo B)]. Desconhece-se a sua presença em unidades de conservação e são poucas as coletas reportadas para esta espécie. 


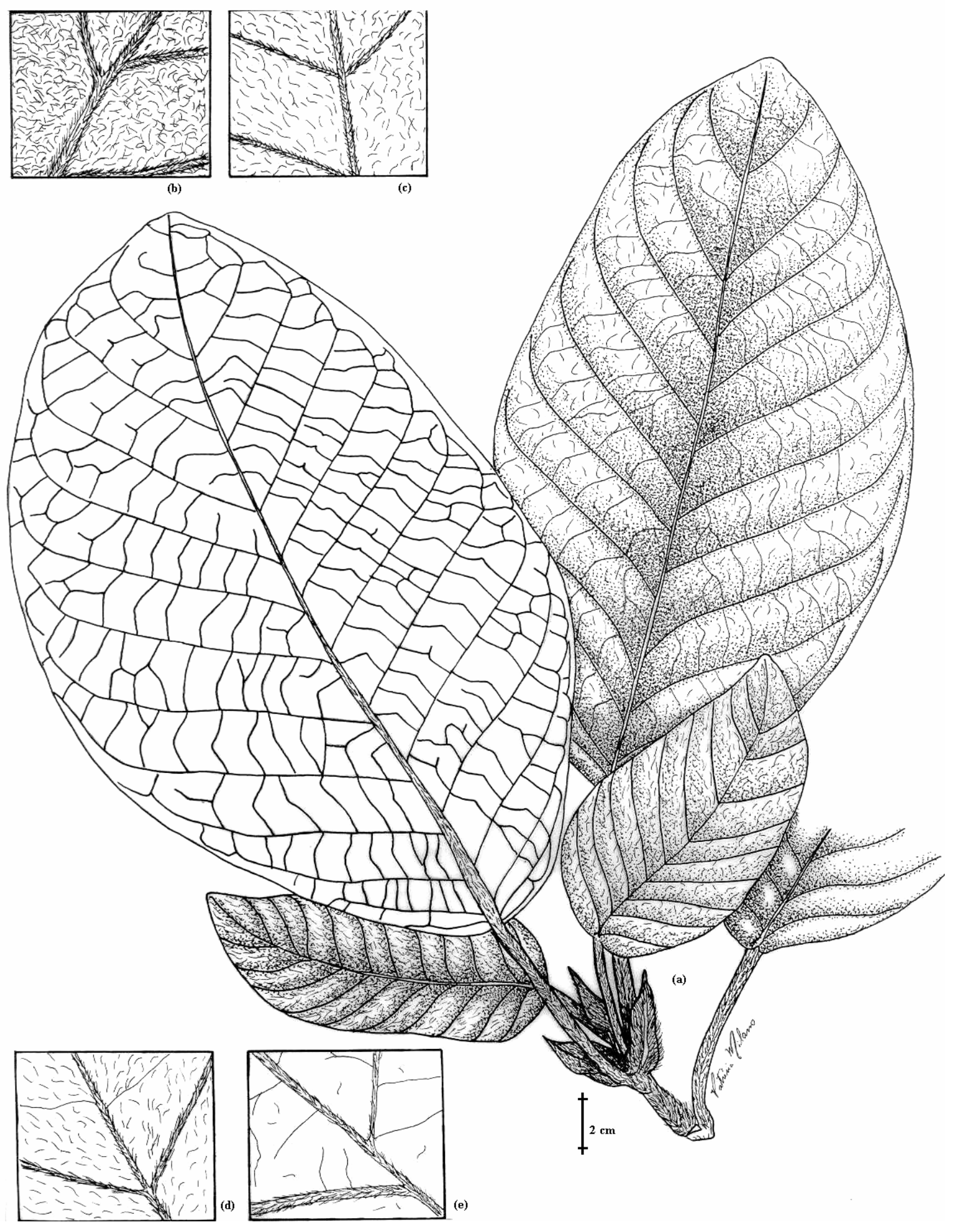

Figura 2 - Cinchona amazonica Standl. - ramo terminal (a), pubescência da face abaxial (c) e adaxial (c) de folha jovem, pubescência da face abaxial (d) e adaxial (e) de folha adulta (d, e ) 

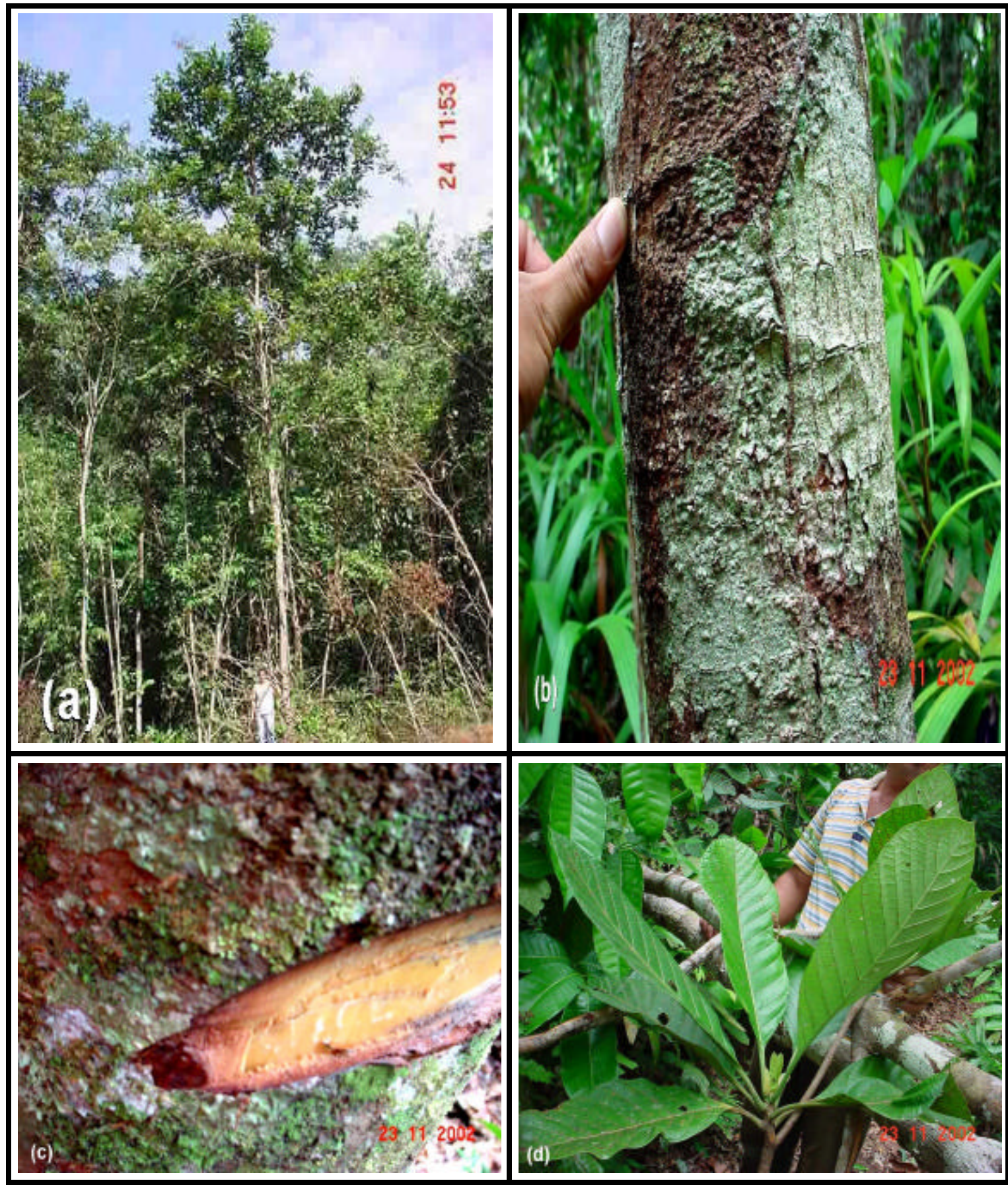

Figura - 3 Cinchona amazonica - (a) árvore em pé, (b) casca externa, (c) casca interna, (d) ramo terminal 

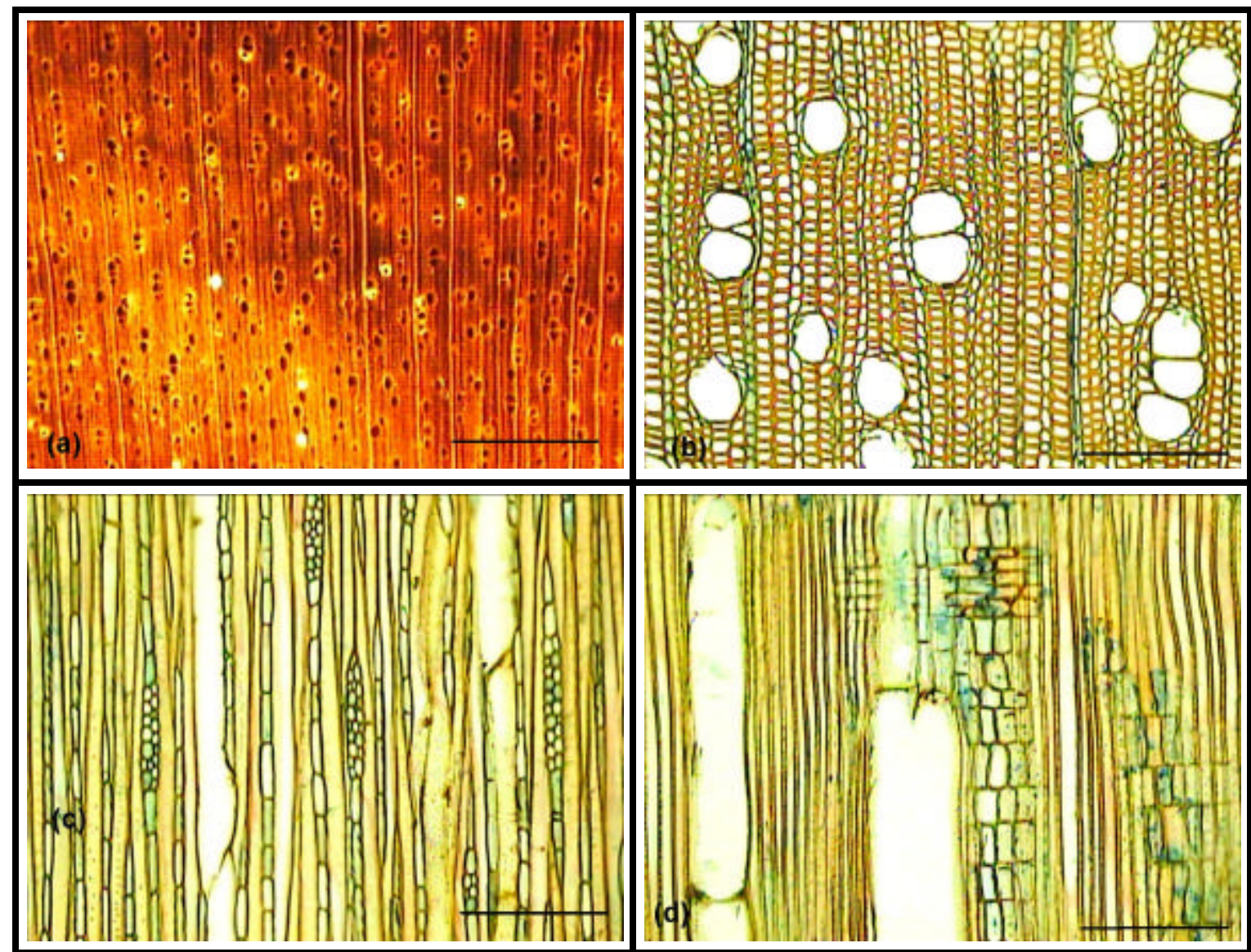

Figura 4 - Cinchona amazonica - (a) seção transversal (10x), (b) seção transversal (50x), (c) seção longitudinal tangencial (50x), (d) seção longitudinal radial do lenho (50x). Escala de barra "a" = $1 \mathrm{~mm}$, "b", "c" e "d" = $250 \mu \mathrm{m}$ 

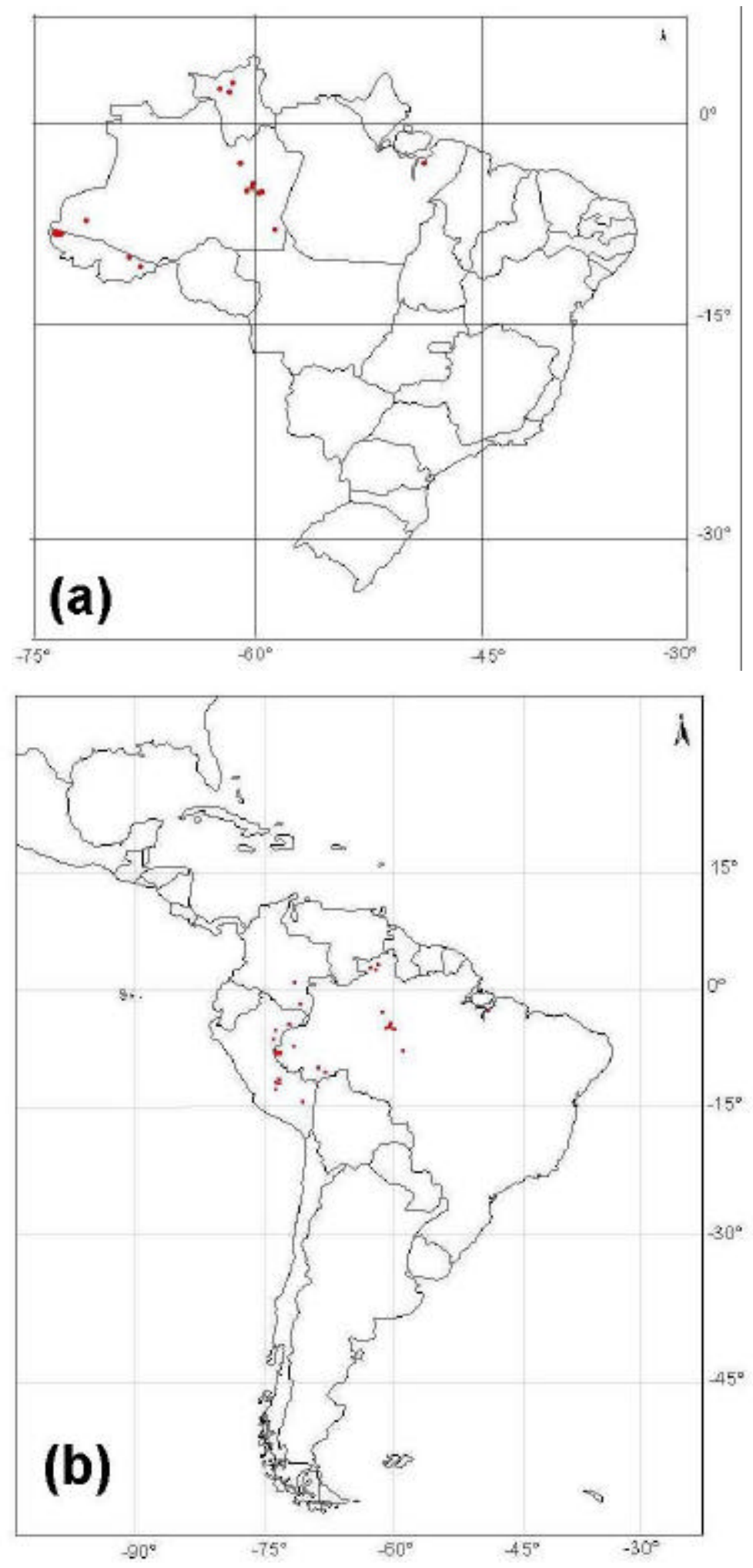

Figura 5 - Distribuição geográfica de Cinchona amazonica no Brasil (a) e na América Latina (b) 
4.2 Croton billbergianus Müll.Arg.

Família botânica: Euphorbiaceae

Publicado em: Linnaea 34: 98. 1865. \{Linnaea; BPH 532.04\}

Tipo: Billberg 316, no date, Panamá: Colón: Portbelo (B).

Sinônimos botânicos: Croton billbergianus subsp. pyramidalis (Donn. Sm.) G.L. Webster \{Ann. Missouri Bot. Gard: 75(3): 1123. 1988\}; Croton calycularis Huber \{Bull. Soc. Bot. Geneve: 6: 181. 1914 \}; Croton grosseri Pax \{Bot. Jahrb. Syst.: 33: 290. 1903 \}; Croton pyramidalis Donn. Sm. \{Bot. Gaz: 35(1): 7-8. 1903 \}.

Nomes vulgares: Brasil: Acre: velame; Costa Rica: targuá; Panamá: sangrillo, vaquero.

\subsubsection{Caracterização dendrológica}

Arbusto mediano, arboreta ou árvore, heliófita de 3-10 m de altura, de 8-20 cm de diâmetro; fuste cilíndrico a cilíndrico irregular; casca externa marrom a marrom vinho, de aparência lenticelar, lenticelas de cor branca, ritidoma não evidente; casca interna branca, textura fibro-laminar; secreta lentamente um látex avermelhado, ligeiramente viscoso, em pequena quantidade. Ramos terminais de seção poligonal irregular, geralmente brancos, folhinhas terminais conduplicadas; com pêlos densamente distribuídos, escamosos estrelados, branco ou branco-creme. Folhas simples e alternas; abovada-cordada, ovada-cordada ou cordada; de 8-21 cm de comprimento e de 5-9 cm de largura, com bordo inteiro ou muito levemente serrado; ápice agudo, às vêzes ligeiramente acuminado; base cordada ou lobulada; pinatinervada oblíqua, com 8 pares de nervuras; consistência papirácea ou cartácea; cor verde claro na parte adaxial, com abundantes pêlos escamoso-estrelado na superfície, com glândulas pequenas microscópicas nas margens e perto das nervuras; na superfície abaxial de cor branca, devido a presença conspícua de pêlos brancos escamosos estrelados, na base, na união com o pecíolo com 2 glândulas sésseis avermelhadas muito conspícuas; pecíolo estriado de até $7 \mathrm{~cm}$ comprimento, de 1,5-2,0 $\mathrm{mm}$ de diâmetro, com pêlos abundantes e escamoso-estrelados; estípulas em par em cada folha, alongadas, com pêlos escamososestrelados e caducas. Inflorescência terminal, tipo racimo, monóicos, de 5-22 cm de comprimento. Flores masculinas abundantes e femininas poucas ou escassas na base. 
Flores unissexuais: flores masculinas de 7-10 mm de comprimento; cálice gamosépalo com 5 dentes, totalmente revestido com pêlos escamo-estrelados; corola com 5 pétalas, creme ou branco-creme, elíptica ou elíptico-abovada, nervura dendriforme ou trinervada, com pêlos longos na base e, hirsutos, semi-curtos na margem, na lâmina cobertos com pêlos escamo-estrelados; androceu com 15 estames livres, com pêlos longos na base dos filamentos, insertos sobre um disco-glandular septado de até $5 \mathrm{~mm}$ de comprimento, com anteras bitecas de 1-1,2 mm de comprimento e deiscência longitudinal; flores femininas de 4-11 mm de comprimento, cálice gamosépalo com 5 dentes bem desenvoltos, totalmente revestido com pêlos escamo-estrelados, corola com 5 pétalas, creme ou branco-creme, elíptica ou elíptico-abovada, nervura dendriforme ou trinervada, com pêlos longos na base e, hirsutos, semi-curtos na margem, na lâmina cobertos com pêlos escamo-estrelados, gineceu verde, ovário súpero, com 3 carpelos, 3 lóculos, cobertos com pêlos escamo-estrelados, cada carpelo com as 2 lâminas laterais desenvoltas, 3-estiletes irregularmente trifurcados. Fruto verde a verde-amarelo, do tipo tricoco, deiscente, semente globosa e oleaginosa (Figuras 6 e 7).

\subsubsection{Caracterização anatômica do lenho}

Cerne indistinto do alburno, de cor esbranquiçada a creme-clara, brilho moderado, odor e gosto imperceptíveis, densidade de massa média, resistência ao corte macia, grã direita, textura média. Camadas de crescimento indistintas ou pouco distintas, demarcadas pela espessura da parede celular das fibras. Vasos visíveis sob lente (10x); difusos; arranjo radial; solitários $(85,42 \%)$ e múltiplos $(14,58 \%)$, freqüência 16-26/mm²; diâmetro tangencial do lume 53,32-106,64 $\mu \mathrm{m}$, média 73,32 $\mu \mathrm{m}$ e desvio padrão 20,12 e forma arredondada; comprimento 333,25-906,44 $\mu \mathrm{m}$, média 562,53 $\mu \mathrm{m}$ e desvio padrão 148,28; apêndice curtos, menor a $1 / 3$ do comprimento do vaso e em ambas extremidades; placas de perfuração simples; depósitos distintos; pontoações intervasculares areoladas, alternas, predominantemente poligonais, menor quantidade arredondadas, abundantes, ornamentação ausente, diâmetro tangencial 3,99-5,02 $\mu \mathrm{m}$, média 4,59 $\mu \mathrm{m}$ e desvio padrão 0,28 ; pontoações raio-vasculares areoladas indistintas; pontoações parênquimo-vasculares semelhantes às intervasculares. Fibras com 


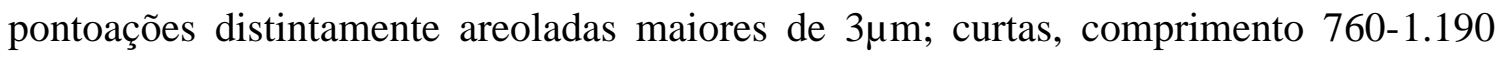
$\mu \mathrm{m}$, média $1010 \mu \mathrm{m}$ e desvio padrão 180; largura média 18,75-40,63 $\mu \mathrm{m}$; espessura da parede delgada com lume de 9,38-21,88 $\mu \mathrm{m}$; pontoações alternas, arredondadas, muito abundantes na seção radial, com diâmetro tangencial 2,79-4,89 $\mu \mathrm{m}$, média 3,05 $\mu \mathrm{m}$ e desvio padrão 0,45. Parênquima axial visível a olho nu e distinto sob lente (10x); apotraqueal difuso em agregados tendendo a formar linhas e paratraqueal escasso; células do tipo seriado. Parênquima radial (raios) visível sob lente (10x), unisseriados $(92,31 \%)$ e multisseriados $(7,69 \%)$ com 2 séries; altura 4,99-9,76 mm, média 6,86 mm e desvio padrão 3,23; freqüência 11-15/mm, média 12,6/mm e desvio padrão 1,43; heterocelulares, com 3 fileiras $(20,99 \%)$ de células eretas no extremo superior, no centro 9 fileiras $(55,55 \%)$ de células procumbentes e 4 fileiras $(23,46 \%)$ de células eretas no extremo inferior; com 832 linhas de células; largura variando de 1,07-26,66 $\mu \mathrm{m}$; no interior da célula com conteúdo de cor marrom [Tabela 3 (Anexo B) e Figura 8].

\subsubsection{Distribuição geográfica}

Esta espécie encontra-se distribuída na Amazônia e na América Central podendo ser encontrada entre as faixas latitudinais (16 50 '00” $\left.\mathrm{N}-10^{\circ} 12^{\prime} 00^{\prime \prime S}\right)$, longitudinais $\left(69^{\circ} 05^{\prime} 00^{\prime \prime} \mathrm{W}-89^{\circ} 37^{\prime} 00^{\prime \prime} \mathrm{W}\right)$ e altitudinais $(10-1000 \mathrm{~m})$ [Tabela 5 (Anexo B)]. Na Amazônia sua distribuição é relativamente ampla, embora os escassos registros não permitam um conhecimento mais completo, com maiores coletas na América Central. Encontrada em Belize, Brasil, Colômbia, Costa Rica, Guatemala, Honduras, México, Panamá e Venezuela. No Brasil nos Estados do Acre, Amazonas, Pará e Rondônia. No Acre nos municípios de Bujari, Cruzeiro do Sul, Rio Branco, Sena Madureira e Tarauacá (Figura 9). Esta espécie sempre se encontra nas bordas dos caminhos, trilhas ou bordas de florestas secundárias em solos argilosos. 


\subsubsection{Status ou situação populacional}

Esta espécie foi incluída na categoria LC (comuns e abundantes, fora de perigo), sendo encontrada com frequiência e abundância nas áreas de ocorrência registradas nas coletas anteriores e muito difícil de ser detectada em outras zonas apesar das tentativas de observação. As populações da espécie encontram-se em áreas expostas sendo considerada geralmente, como espécie daninha e eliminada nas operações de limpeza do terreno para uso agropecuário ou queimada [Tabela 7 (Anexo B)]. Desconhece-se a sua presença em unidades de conservação e coletas recentes são escassas. 


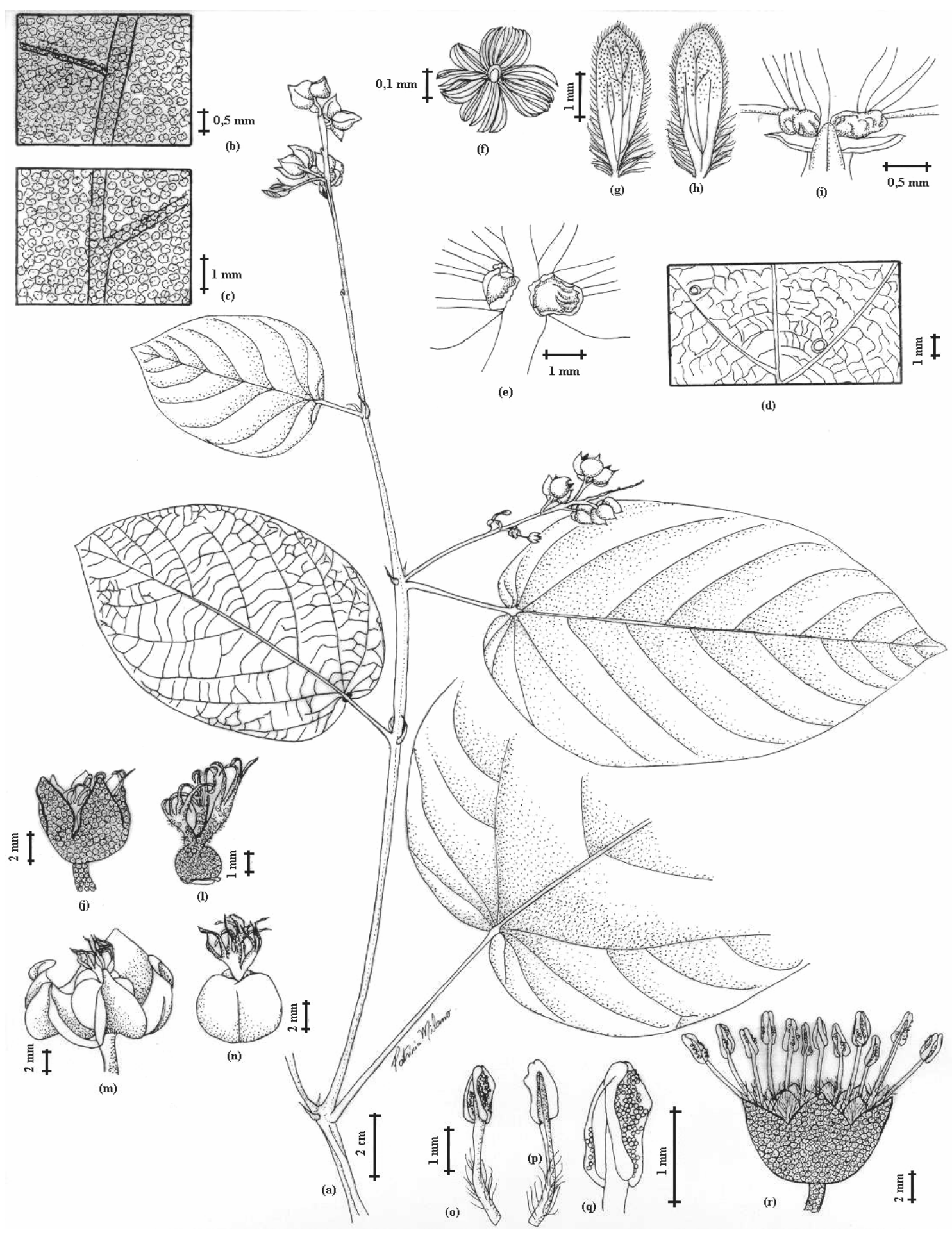

Figura 6 - Croton billbergianus Müll.Arg. - ramo terminal com inflorescência (a), pêlos da face abaxial (b) e adaxial (c) da folha, glândulas na parte adaxial (d), glândulas na base da folha face abaxial (e), pêlo escamo -estrelado (f), pétalas na face abaxial (g) e adaxial (h), disco glandular (i), flor feminina (j) e gineceu não fecundada (l), flor e gineceu fecundado $(m, n)$, estames e antera $(o, p$, q), flor masculina (r) 

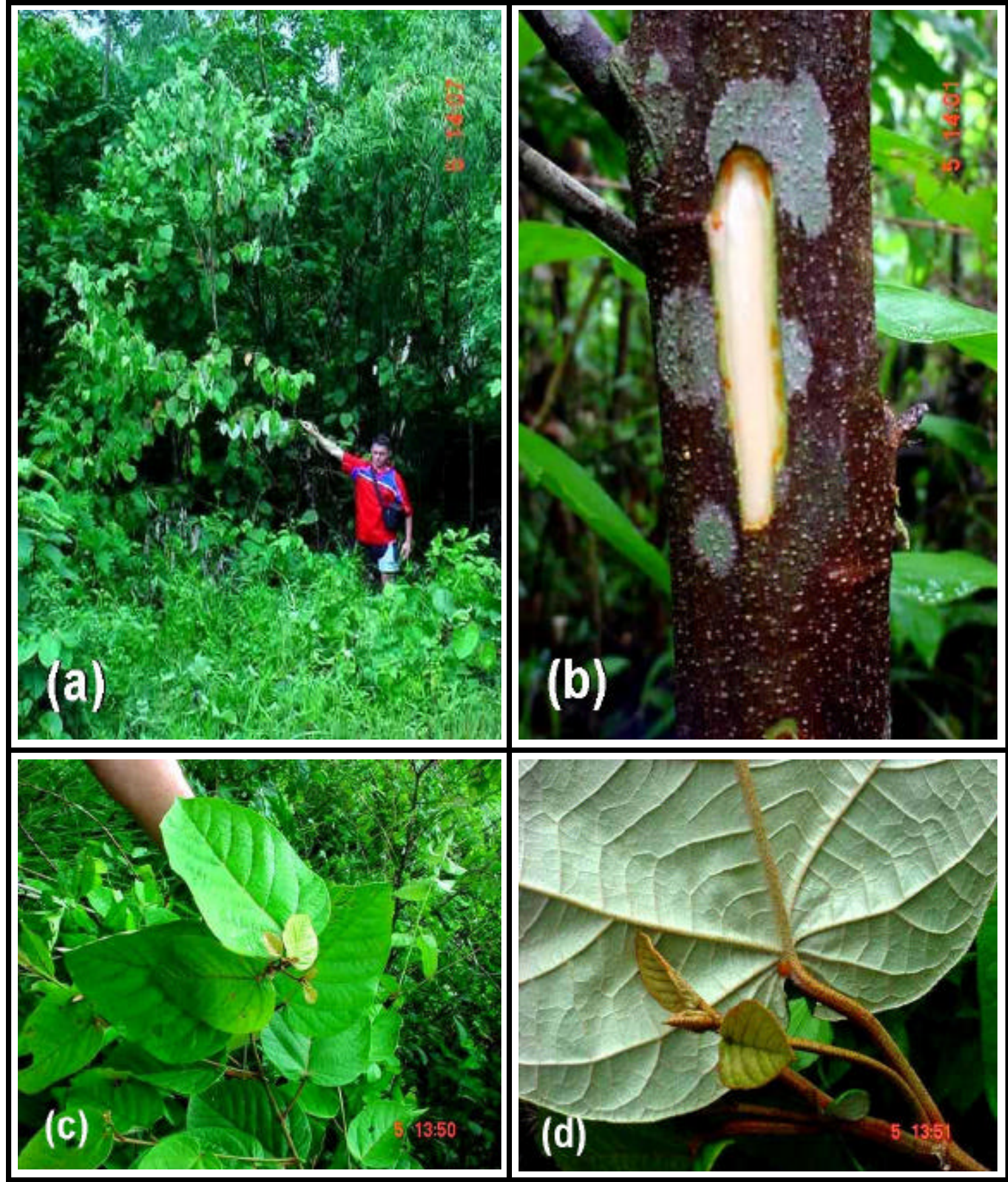

Figura 7 - Croton billbergianus - (a) árvoreta em pé, (b) casca externa e interna, (c) ramo terminal, (d) glândulas da folha 


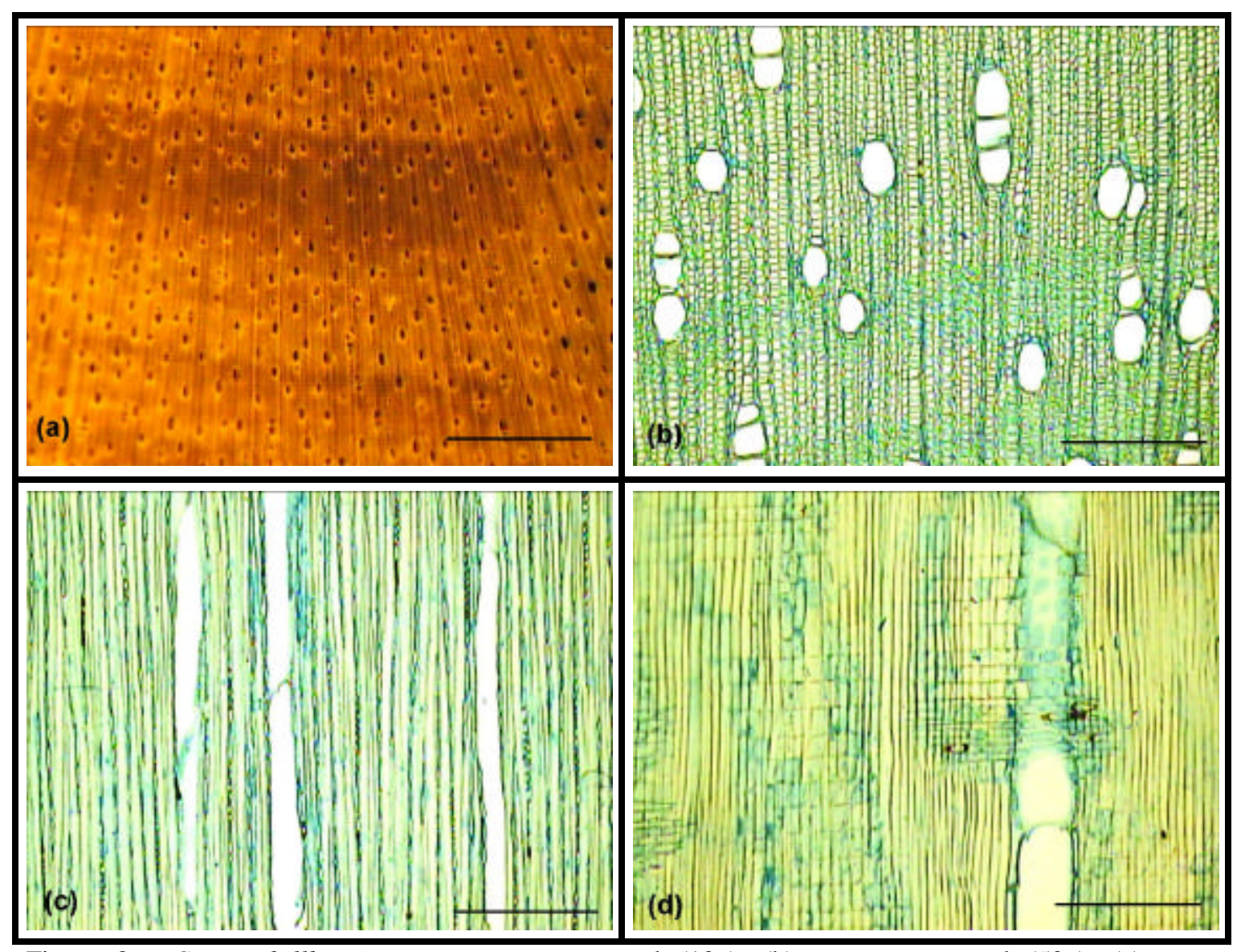

Figura 8 - Croton billbergianus - seção transversal (10x), (b) seção transversal (50x), (c) seção longitudinal tangencial $(50 \mathrm{x})$, (d) seção longitudinal radial do lenho $(50 \mathrm{x})$. Escala de barra "a" = $1 \mathrm{~mm}$, "b", "c" e "d"= $250 \mu \mathrm{m}$ 

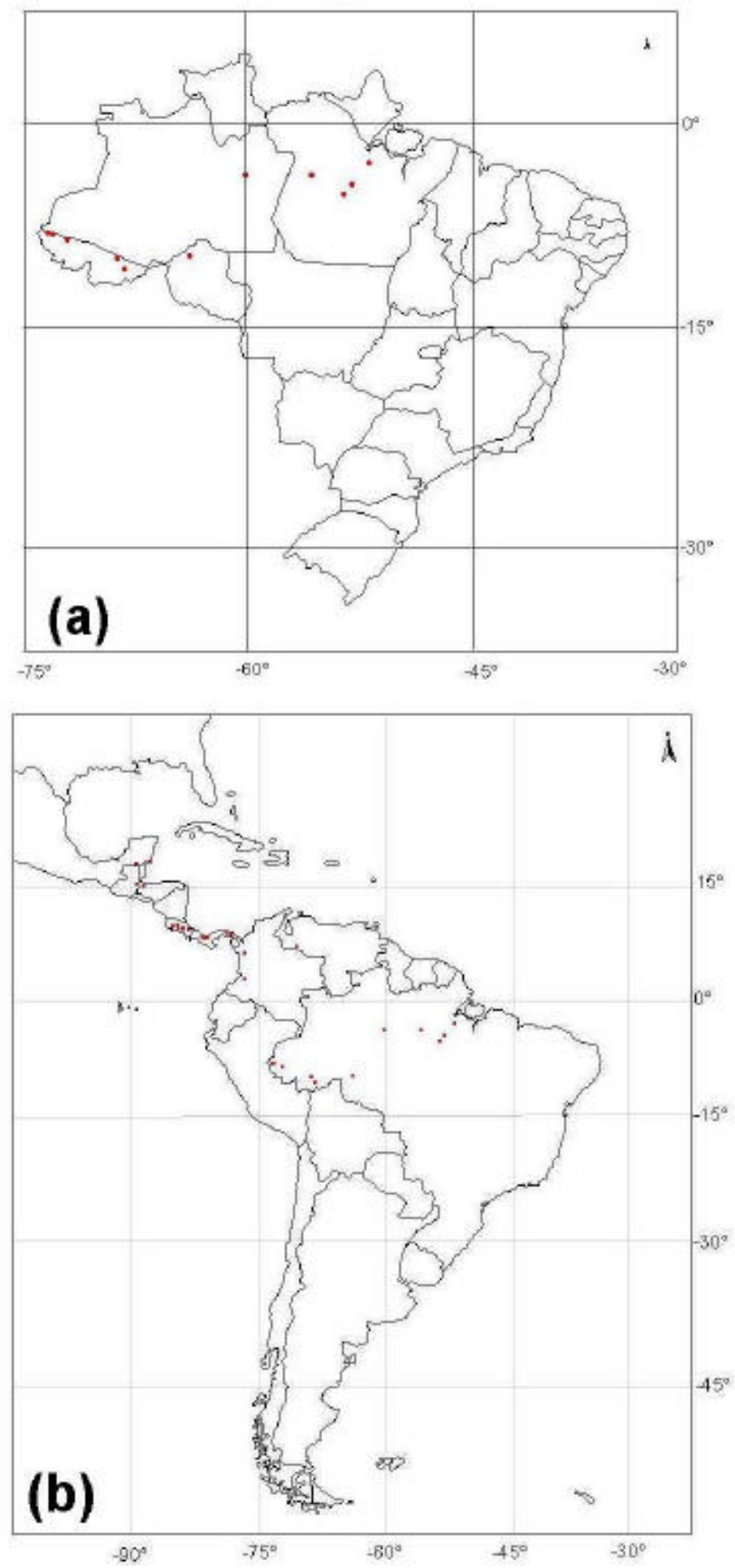

Figura 9 - Distribuição geográfica de Croton billbergianus no Brasil (a) e na América Latina (b) 


\subsection{Croton floribundus Spreng.}

Família botânica: Euphorbiaceae

Publicado em: Systema Vegetabilium, editio decima sexta 3: 873. 1826.\{Syst.Veg.\}

Tipo: Desconhecido

Sinônimo botânico: Croton floribundus Lund ex Didr \{Kjoeb.Videmsk. Meddel. (1857) 139\}; Croton floribundus var. piauhyensis C.T. Rizzini \{Rodriguésia : 41: 167. 1976\}; Croton urticifolius Lam .\{Encycl. 2:219 (1786)\}; Oxydectes floribunda Kuntze \{Revis. Gen. P1. 2: 611. 1891\}.

Nomes vulgares: Brasil: Acre: velame; Maranhão: capixingui, capinxingui-de-lika; Minas Gerais: capiocingui, capinxingui, sangue-drago; Paraíba: marmeleiro; Paraná: capixingui; São Paulo: adrago, andrajo-barca, apingui, capechingui, capiacingui, capixingui, capi-xingui-branca, lixeira, pau-caxeta, sangra-dágua, sangue-de-dragão, sangue-de-drago, tapixingui, capoeira-preta, caxeta-tapixingui, urucurana, velame-decheiro, velame.

\subsubsection{Caracterização dendrológica}

Arbusto, arboreta ou árvore, pioneira e heliófita, de 4-12 m de altura e 8-30 cm de diâmetro; copa globosa irregular; fuste forma cilíndrico-irregular; casca externa creme-bege a cinza, de aparência nodosa quando arbusto e fissurada quando árvore madura, ritidoma não evidente; casca interna de cor creme-amarelado ou creme-verdoso, de 5-8 $\mathrm{mm}$ de espessura, textura fibro-laminar; secreta lentamente um látex semivermelho aquoso de sabor adstringente, ligeiramente viscoso e em pequena quantidade.

Ramos terminais de seção poligonal, marrom claro; folhinhas terminais conduplicadas; com pêlos estrelados densos, cor bege ou marrom claro. Folhas simples e alternas; elípticas ou elíptico-lanceoladas; de $5-8 \mathrm{~cm}$ de largura e 11-24 cm de comprimento; bordo inteiro ou levemente sinuado; ápice agudo, com acúleo; base obtusa ou redonda; nervura pinatinervada reta a reta-curvada, com até 23 pares de nervuras, densamente pubescentes; consistência cartácea; na superfície adaxial verde e glabra, mas podem ser observadas manchas pequenas; na superfície abaxial branca ou branco-bege, pela presença de pêlos estrelados e brancos em alta densidade, mais escuros nas nervuras, 
ademais apresentam um par de glândulas na base quase globulares; pecíolo estriado, de 1,8-2,5 cm de comprimento e 1,5-2 mm de diâmetro, com densos pêlos estrelados, bege ou marrom; estípulas foliares, ásperas, com pêlos e caducas. Inflorescência terminal, tipo racimo; monoico; de 20-30 cm de comprimento. Flores masculinas abundantes na parte superior e, as femininas escassas na base. Flores unissexuais: flores masculinas de 6-7 $\mathrm{mm}$ de comprimento, cálice gamosépalo com 5 dentes, totalmente revestido com pêlos estrelados, corola com 5 pétalas, creme ou branco-creme, abovada ou espatulada, nervura trinervada, com pêlos semi-longos da metade a base e, hirsutos, curtos na margem, na lâmina cobertos com pêlos estrelados, androceu com 15 estames livres, com pêlos semi-longos na base dos filetes, insertos sobre um disco glandular septado, de até 7 mm de comprimento, com anteras bitecas de 0,8-1,0 $\mathrm{mm}$ de comprimento e deiscência longitudinal; flores femininas de 5-7,5 mm de comprimento; cálice gamosépalo com 5 lóbulos bem desenvoltos, totalmente revestido com pêlos estrelados, corola com 5 pétalas, cremes ou branco-cremes, abovada ou espatulada, nervura trinervada, com pêlos semi-longos na base e, hirsutos, curtos na margem, na lâmina coberta com pêlos estrelados, gineceu verde, ovário súpero, com 3 carpelos, 3 lóculos, cobertos com pêlos estrelados, 3-estiletes irregularmente trifurcados na maturação. Fruto seco, tipo tricoco, marrom- verdoso. Semente de forma arredondada (Figuras 10 e 11).

\subsubsection{Caracterização anatômica do lenho}

Cerne indistinto do alburno, de cor amarelado-clara, brilho moderado, odor e gosto imperceptíveis, densidade de massa médio-baixa, resistência ao corte macia, grã direita, textura média. Camadas de crescimento distintas, demarcadas pela espessura da parede celular das fibras. Vasos visíveis a olho nu; difusos; arranjo radial; solitários $(41,18 \%)$ e múltiplos $(58,82 \%)$, em grupos de 2-3, freqüência 16-21/mm²; diâmetro tangencial do lume 20-106,64 $\mu \mathrm{m}$, média 55,32 $\mu \mathrm{m}$ e desvio padrão 24,35 e forma arredondada; comprimento 373,24-933,10 $\mu \mathrm{m}$, média 581,19 $\mu \mathrm{m}$ e desvio padrão 178,09; apêndices curtos, menor a $1 / 3$ do comprimento do vaso e em ambas extremidades; placas de perfuração simples; depósitos distintos; pontoações intervasculares areoladas, alternas, predominantemente arredondadas, menor quantidade 
poligonal, abundantes, ornamentação ausente, diâmetro tangencial 3,87-6,85 $\mu \mathrm{m}$, média 4,56 $\mu \mathrm{m}$ e desvio padrão 0,78; pontoações raio-vasculares areoladas, alternas, arredondadas, abundantes, diâmetro tangencial 3,68-5,21 $\mu \mathrm{m}$, média 4,41 $\mu \mathrm{m}$ e desvio padrão 0,41; pontoações parenquimo-vasculares semelhantes às intervasculares. Fibras com pontoações distintamente areoladas maiores do que $3 \mu \mathrm{m}$; muito curtas a curtas, comprimento 860-1410 $\mu \mathrm{m}$, média $1040 \mu \mathrm{m}$ e desvio padrão 200; largura 18,75-34,38 $\mu \mathrm{m}$; espessura da parede delgada com lume de 12,50-18,75 $\mu \mathrm{m}$; pontoações alternas, arredondadas, muito abundantes, raras na seção radial, com diâmetro tangencial 2,024,45 $\mu \mathrm{m}$, média 3,22 $\mu \mathrm{m}$ e desvio padrão 0,58. Parênquima axial visível a olho nu; parênquima apotraqueal difuso em agregados tendendo a formar linhas; células do tipo seriado. Parênquima radial (raios) visível a olho nu, unisseriados $(94,74 \%$ ) e multisseriados (5,26\%) geralmente 2 séries; altura 3,25-4,34 mm, média 4,12 $\mathrm{mm} \mathrm{e}$ desvio padrão 1,55; frequiência 9-11/mm, média 9,8/mm e desvio padrão 0,92; heterocelulares, com 3 fileiras (20\%) de células eretas no extremo superior, no centro 12 fileiras $(69,41 \%)$ de células procumbentes e 2 fileiras $(10,59 \%)$ de células eretas no extremo inferior; com 13-23 linhas de células; largura variando de 13,33-26,66 $\mu \mathrm{m}$; no interior da célula com conteúdo de cor avermelhado [Tabela 3 (Anexo B) e Figura 12].

\subsubsection{Distribuição geográfica}

Esta espécie se encontra principalmente no Brasil, sendo seu primeiro registro na Amazônia, ocorrendo entre as faixas latitudinais $\left(02^{\circ} 49^{\prime} 00^{\prime \prime} \mathrm{N}-25^{\circ} 45^{\prime} 15^{\prime \prime} \mathrm{S}\right)$, longitudinais (36³5’33”W-74³5”08”W) e altitudinais (195-1700 m) [Tabela 5 (Anexo B)]. Sua distribuição é ampla no sudeste brasileiro com registro, também, no Paraguai. Os registros na Amazônia são inexistentes. No Brasil encontra-se nos Estados do Acre, Bahia, Ceará, Goiás, Maranhão, Mato Grosso do Sul, Minas Gerais, Paraíba, Paraná, Pernambuco, Rio de Janeiro e São Paulo. No Acre foi encontrada no município de Mâncio Lima (Figura 13). Espécie encontrada nas bordas de florestas aproveitadas ou em processo de exploração, sobre solos argilosos. 


\subsubsection{Status de conservação ou situação populacional}

Esta espécie foi incluída na categoria DD (espécie informação disponível inadequada) pelo fato de realmente se constituir em uma espécie de rara ocorrência na Amazônia, enquando a sua área de distribuição está concentrada no sudeste do Brasil. As coletas de expedições realizadas no passado não relatam ou não detectaram a presença deste grupo botânico. Nas áreas de amostragem e outros locais foi procurada, mas não foi encontrada [Tabela 7 (Anexo B)]. Os escassos indivíduos encontram-se em áreas expostas, podendo ser eliminados pela ampliação da fronteira agropecuária. Desconhece-se a sua presença em unidades de conservação e coletas botânicas fora de sua área de origem são bem mais escassas. 


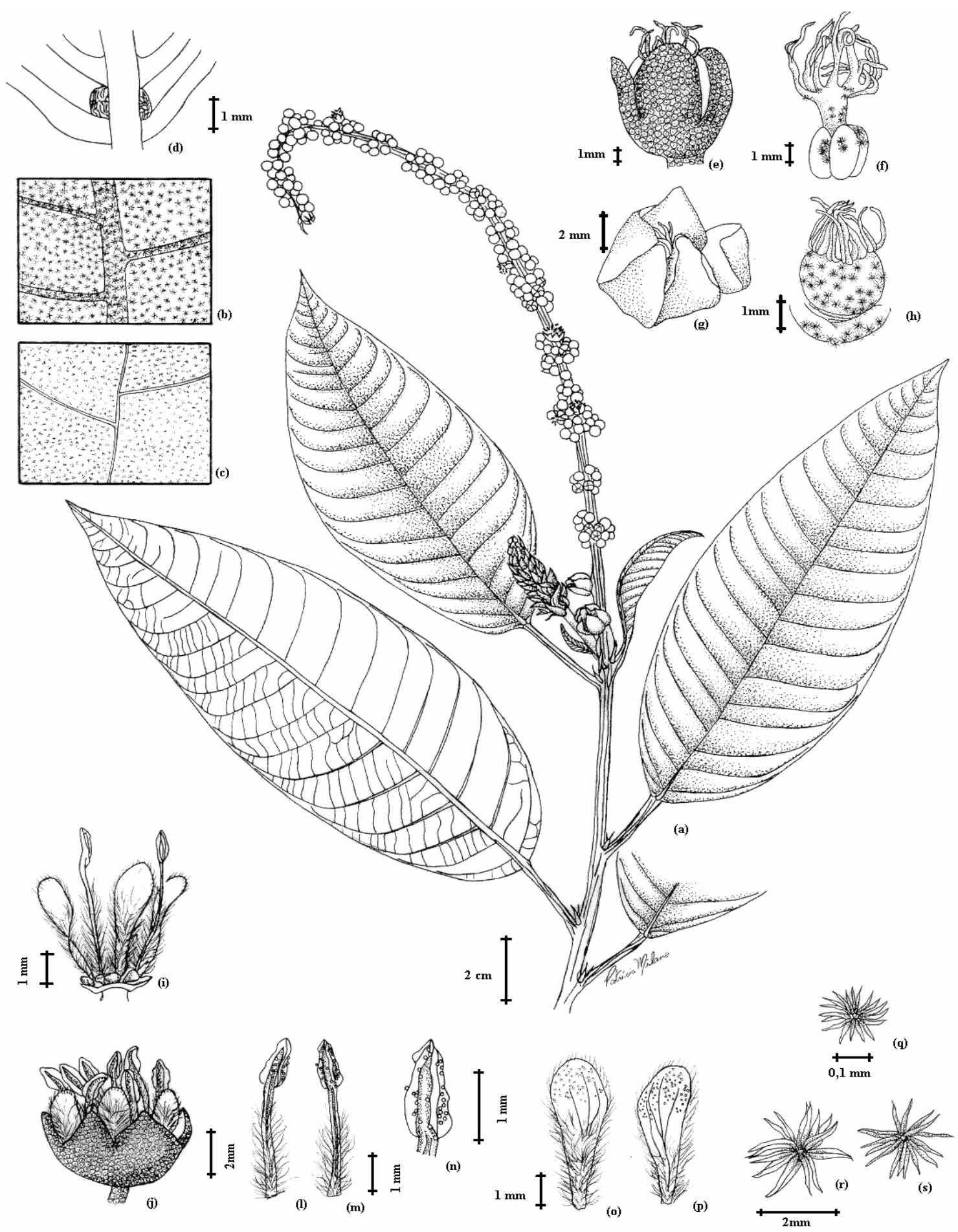

Figura 10 - Croton floribundus Spreng. - ramo terminal com inflorescência (a), pubescência na folha face abaxial (b) e face adaxial glabra (c), glândula na base da folha face abaxial (d), flor feminina (e) e gineceu não fecundado (f), flor feminina (g) e gineceu fecundado (h), disco com inserção de pétalas e estames (i), flor masculina (j), estames e antera $(1, m, n)$, pétalas na face abaxial e adaxial (o, p), pêlo estrelado da flor (q), pêlos da folha $(r, s)$ 

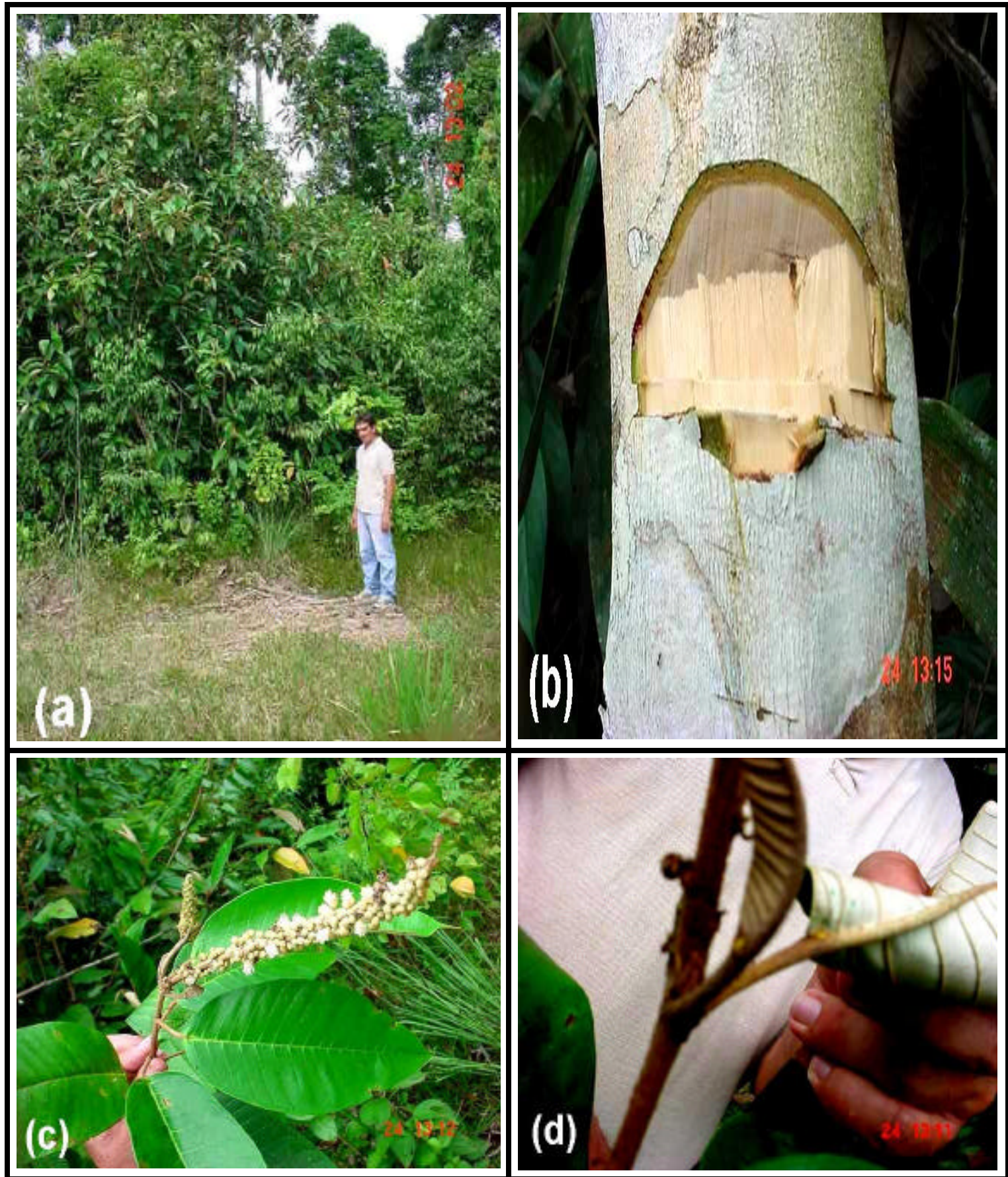

Figura 11 - Croton floribundus - (a) arvoreta em pé, (b) casca externa e interna, (c) ramo terminal com folhas e inflorescência, (d) glândulas da folha 


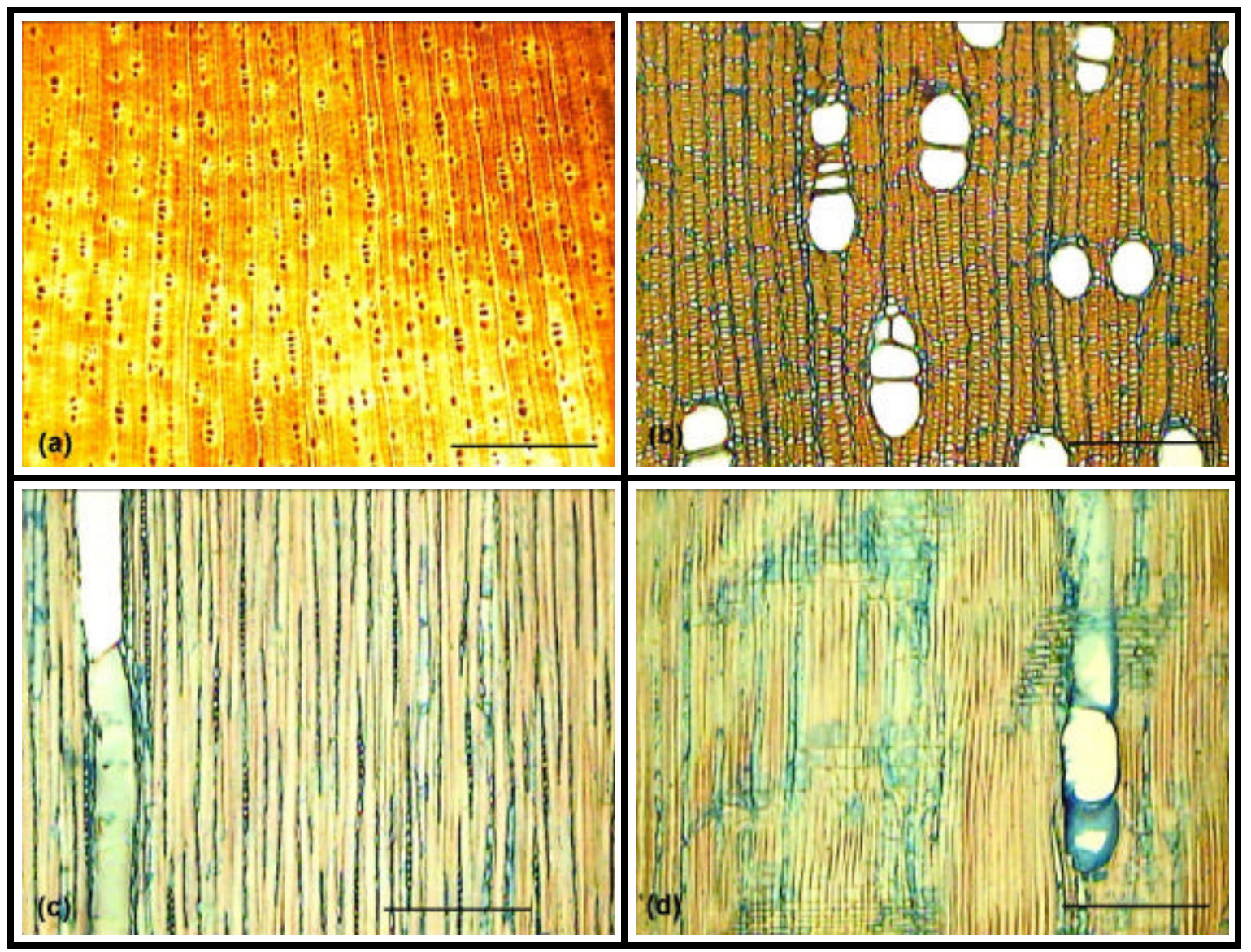

Figura 12 - Croton floribundus (a) - (a) seção transversal (10x), (b) seção transversal (50x), (c) seção logitudinal tangencial (50x), (d) seção longitudinal radial do lenho (50x). Escala de barra "a" = $1 \mathrm{~mm}$, "b", "c" e "d" = $250 \mu \mathrm{m}$ 

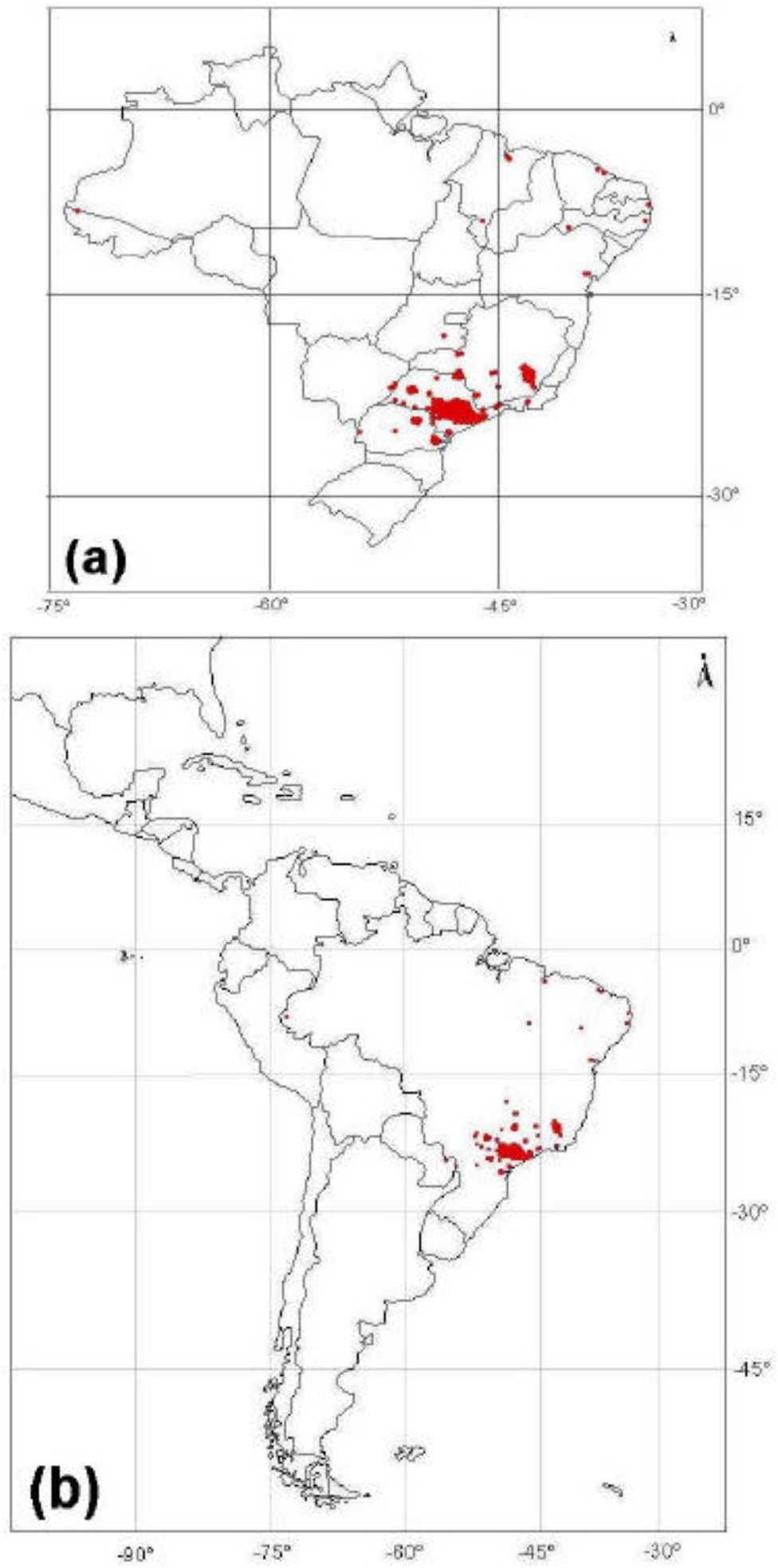

Figura 13 - Distribuição geográfica de Croton floribundus no Brasil (a) e na América Latina (b) 


\subsection{Croton lechleri Müll. Arg.}

Família botânica: Euphorbiaceae

Publicado em: Prodromus Systematis Naturalis Regni Vegetabilis 15(2): 545. 1866. \{Prodr. .

Tipo: Ruiz 603, 1778-88, Peru (B).

Sinônimo botânico: Croton draco var. cordatus Müll. Arg. \{Linnaea 34: 90. 1865\}; Oxydectes lechleri Kuntze \{Revis. Gen. P1 2: 612. 1891\}.

Nomes vulgares: Brasil: Acre: sangue-de-grado; Bolívia: sangre de grado; Colômbia: sangregrado; Equador: balsa macho, sangre de grado; Peru: sangre de drago, sangre de grado, topa roja, uruchnumi.

\subsubsection{Caracterização de ndrológica}

Árvore pioneira e heliófita de até $20 \mathrm{~m}$ de altura, de $20-40 \mathrm{~cm}$ de diâmetro; fuste cilíndrico ou cilíndrico-irregular; copa com forma de pára-sol, com ramas irregularmente distribuídas; casca externa bege-cinza, com cicatrizes em forma de meia lua, com manchas verde-azuladas; casca interna branca ou creme-branca, textura fibrolaminar; secreta abundantemente látex vermelho, de sabor adstringente e viscosa. Ramos terminais de seção circular, geralmente bege-cinza, folhinhas terminais conduplicadas; com pêlos densamente distribuídos, estrelados, bege ou bege-creme. Folhas simples, alternas, quase agrupadas ao extremo; evidentemente cordadas; de 10$30 \mathrm{~cm}$ de comprimento, de 6-20 cm de largura, com bordo inteiro ou levemente sinuado; ápice agudo, ligeiramente ou evidentemente acuminado; base cordada; palmatinervada ou pinatinerva , com mais de 7 pares de nervuras; consistência papirácea ou cartácea; cor verde pálido na superfície adaxial, com abundantes pêlos estrelados nas nervuras, ademais com 2 ou mais de 3 glândulas na base e outras pequenas, microscópicas nas margens e perto das nervuras; na face abaxial de cor verde mais escuro, pela presença de pêlos bege estrelados na superfície toda. Pecíolo longo de até $25 \mathrm{~cm}$ de comprimento e 3,5-5 mm de diâmetro, com pêlos abundantes e estrelados. Estípulas em par com cada folha, alongadas e caniculares ou cordadas, com pêlos estrelados e caducas. Inflorescências grandes, terminais ou subterminais, tipo racimo, monóicos, de mais de 
$30 \mathrm{~cm}$ de comprimento. Flores masculinas abundantes e femininas poucas ou escassas na base. Flores unissexuais: flores masculinas de 5-6 $\mathrm{mm}$ de comprimento; cálice dialisépalo com 5 sépalas, totalmente revestido cada um com pêlos estrelados; corola com 5 pétalas, cremes ou branco-cremes, oblonga ou oblongo-abovada, nervura dividese em 2, com pêlos hirsutos desde a base até a margem da lâmina, ademais superfície coberta com pêlos estrelados; androceu com 15 estames livres, insertos sobre um discoglandular septado, com anteras bitecas de 0,5-0,6 $\mathrm{mm}$ de comprimento e deiscência longitudinal; flores femininas de 5-12 mm de comprimento; cálice gamosépalo com 5 dentes, totalmente revestido com pêlos estrelados; corola com 5 pétalas, creme ou branco-creme, oblonga ou oblongo-abovado, nervura divide-se em 2 com pêlos hirsutos desde a base até a margem da lâmina, superfície cobertas com pêlos estrelados; gineceu verde, ovário súpero, 3-carpelos, 3 lóculos, cobertos com pêlos estrelados, 3-estiletes duas vezes dividido. Fruto verde a verde-amarelado, do tipo tricoco, coberto com pêlos estrelados, deiscentes, sementes globosas e oleaginosas (Figuras 14 e 15).

\subsubsection{Caracterização anatômica do lenho}

Cerne indistinto do alburno, de cor branco-acinzado, brilho acentuado, odor e gosto imperceptíveis, densidade de massa baixa, resistência ao corte macia, grã direita, textura média. Camadas de crescimento pouco distintas, demarcadas pela espessura da parede celular das fibras. Vasos visíveis a olho nu; difusos; arranjo radial; solitários $(26,67 \%)$ e múltiplos $(73,33 \%)$, grupos de $2-3$ raro 4 , frequiência $5-9 / \mathrm{mm}^{2}$; diâmetro tangencial do lume 66,65-239,94 $\mu \mathrm{m}$, média 149,30 $\mu \mathrm{m}$ e desvio padrão 50,97 e forma arredondada; comprimento 266,60-826,46 $\mu \mathrm{m}$, média 581,19 $\mu \mathrm{m}$ e desvio padrão 185,90; apêndice curtos, menor a $1 / 3$ do comprimento do vaso e em ambas extremidades; placas de perfuração simples; depósitos distintos; pontoações intervasculares areoladas, alternas, predominantemente poligonais, abundantes, ornamentação ausente, diâmetro tangencial 5,26-8,84 $\mu \mathrm{m}$, média 7,42 $\mu \mathrm{m}$ e desvio padrão 0,49; pontoações raio-vasculares areoladas, alternas, arredondadas; abundantes, muito mais na seção radial, diâmetro tangencial 2,88-4,78 $\mu$ m, média 3,95 $\mu \mathrm{m}$ e desvio padrão 0,56; pontoações parênquimo-vasculares semelhantes às intervasculares. Fibras 
com pontoações distintamente areoladas maiores de $3 \mu \mathrm{m}$; curtas, comprimento 1.260$1.370 \mu \mathrm{m}$, média $1.310 \mu \mathrm{m}$ e desvio padrão 40; largura 25-34,38 $\mu \mathrm{m}$; espessura da parede delgada com lume de 15,63-21,88 $\mu \mathrm{m}$; pontoações alternas, arredondadas, mais abundantes na seção radial, com diâmetro tangencial 2,49-5,64 $\mu \mathrm{m}$, média 4,03 $\mu \mathrm{m}$ e desvio padrão 0,67. Parênquima axial visível a olho nu; paratraqueal aliforme linear, formando confluências longas e apotraqueal difuso. Parênquima radial (raios) visível a olho nu, unisseriados $(61,54 \%)$ e multisseriados $(38,46 \%)$ geralmente 2 séries; altura 1,73-3,91 mm, média 2,69 mm e desvio padrão 1,35; frequiência 7-9/mm, média 8,1/mm e desvio padrão 0,88; heterocelulares, com 2 fileiras $(10,34 \%)$ de células eretas na extremidade superior, no centro 13 fileiras $(74,72 \%)$ de células procumbentes e 3 fileiras $(14,94 \%)$ de células eretas na extremidade inferior; com 8-23 linhas de células; largura variando de 13,33-39,99 $\mu \mathrm{m}$ no interior da célula com conteúdo de cor avermelhado [Tabela 3 (Anexo B) e Figura 16].

\subsubsection{Distribuição geográfica}

Espécie de ampla distribuição na Amazônia podendo, também, ser encontrada nas vertentes do Oceano Pacifico entre as faixas latitudinais $\left(01^{\circ} 06^{\prime} 00^{\prime} \mathrm{N}-17^{\circ} 44^{\prime} 00^{\prime \prime S}\right)$, longitudinais (6340'00” W-7950”00”W) e altitudinais (100-2100 m) [Tabela 5 (Anexo B)]. Esta espécie distribui-se, principalmente, no oeste da Amazônia; também pode ser encontrada nas vertentes ocidentais, em locais ecologicamente semelhantes da floresta úmida tropical, como na Província do Guayas-Equador, região da cordilheira dos Andes de baixa altitude. Encontra-se na Bolívia, Brasil, Colômbia, Peru e Equador. No Brasil só no Estado do Acre. No Acre nos municípios de Assis Brasil, Brasiléia, Epitaceolândia, Rio Branco, Plácido Castro e Xapuri (Figura 17). Encontra-se principalmente nas beiras dos rios ou cachoeiras, sobre solos ricos em nutrientes.

\subsubsection{Status ou situação populacional}

Esta espécie foi incluída na categoria CR (perigo crítico) pelo fato de só ser encontrada em locais pontuais e próximos da fronteira com a Bolívia e o Peru, onde é muito comum. As coletas no Acre são recentes, não tendo sido localizados registros 
anteriores. Os escassos exemplares encontram-se em áreas expostas e são eliminados por competir com culturas agrícolas (banana, mandioca, etc.) ou pelos colonos para extrair todo o seu látex e, posteriormente, comercializá-lo nos mercados de Rio Branco [Tabela 7 (Anexo B)]. Desconhece-se a sua presença em unidades de conservação. 


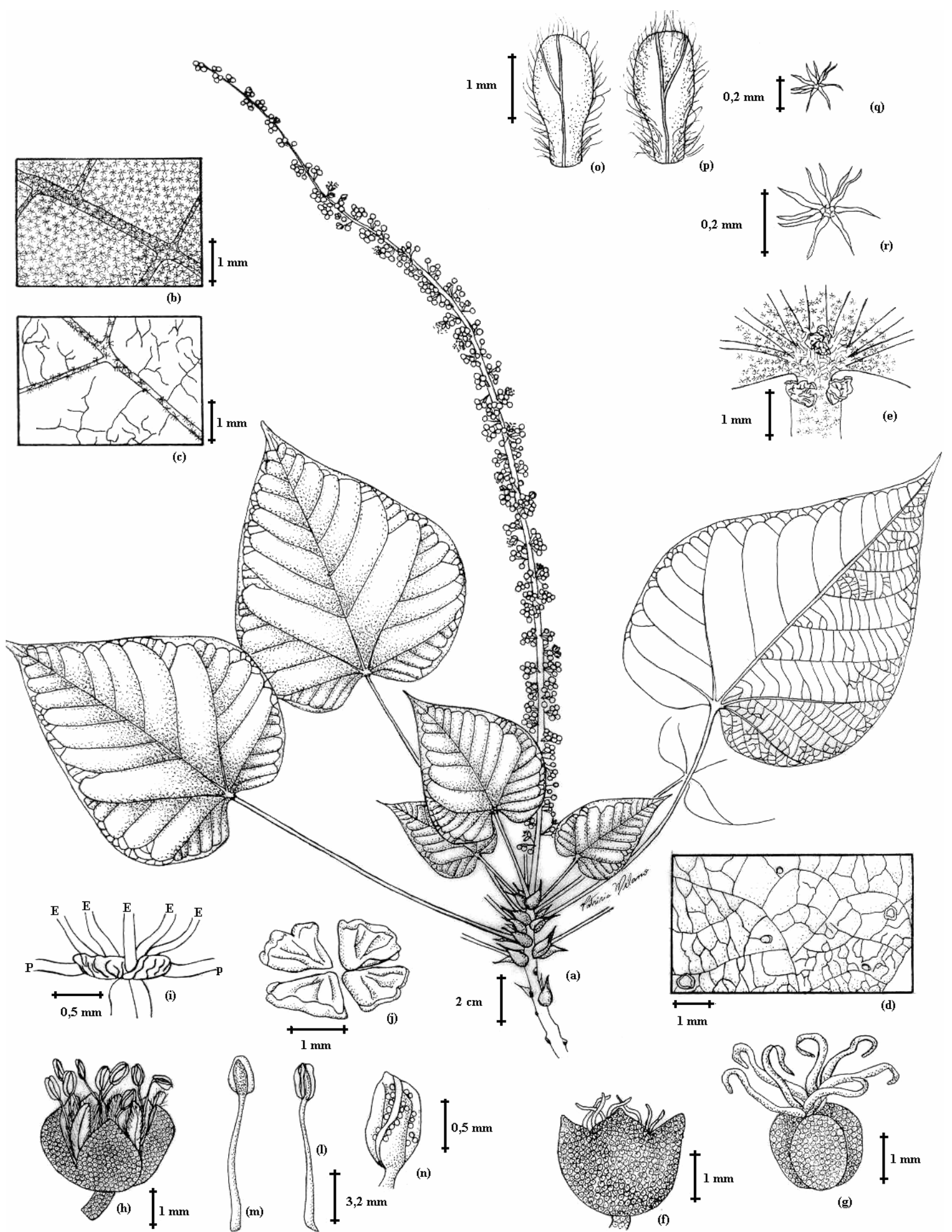

Figura 14 - Croton lechleri Müll.Arg. - ramo terminal com inflorescência (a), pubescência da folha face abaxial (b) e adaxial (c), glândulas na superficie da face adaxial (d), glândulas na base da folha face adaxial (e), flor feminina (f) e gineceu não fecundado (g), flor masculina (h), disco glandular da flor masculina $(i, j)$, estames $(1, m)$, antera $(n)$, pétalas fase abaxial (o) e adaxial (p) da flor masculina, pêlo da flor (q), pêlo da folha (r) 

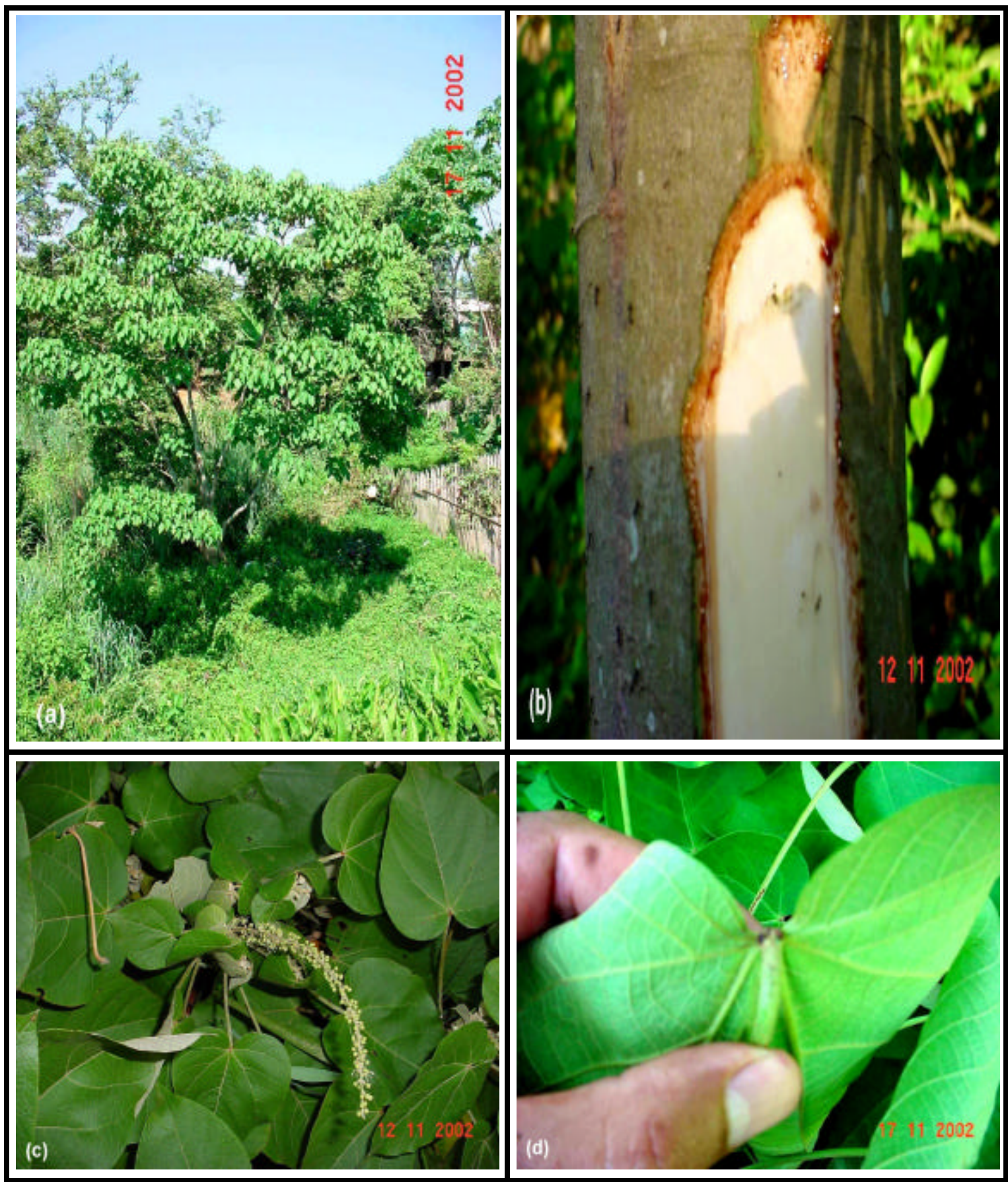

Figura 15 - Croton lechleri - (a) árvore em pé, (b) casca externa e interna, (c) ramo terminal com folhas e inflorescência, (d) glândulas da folha 

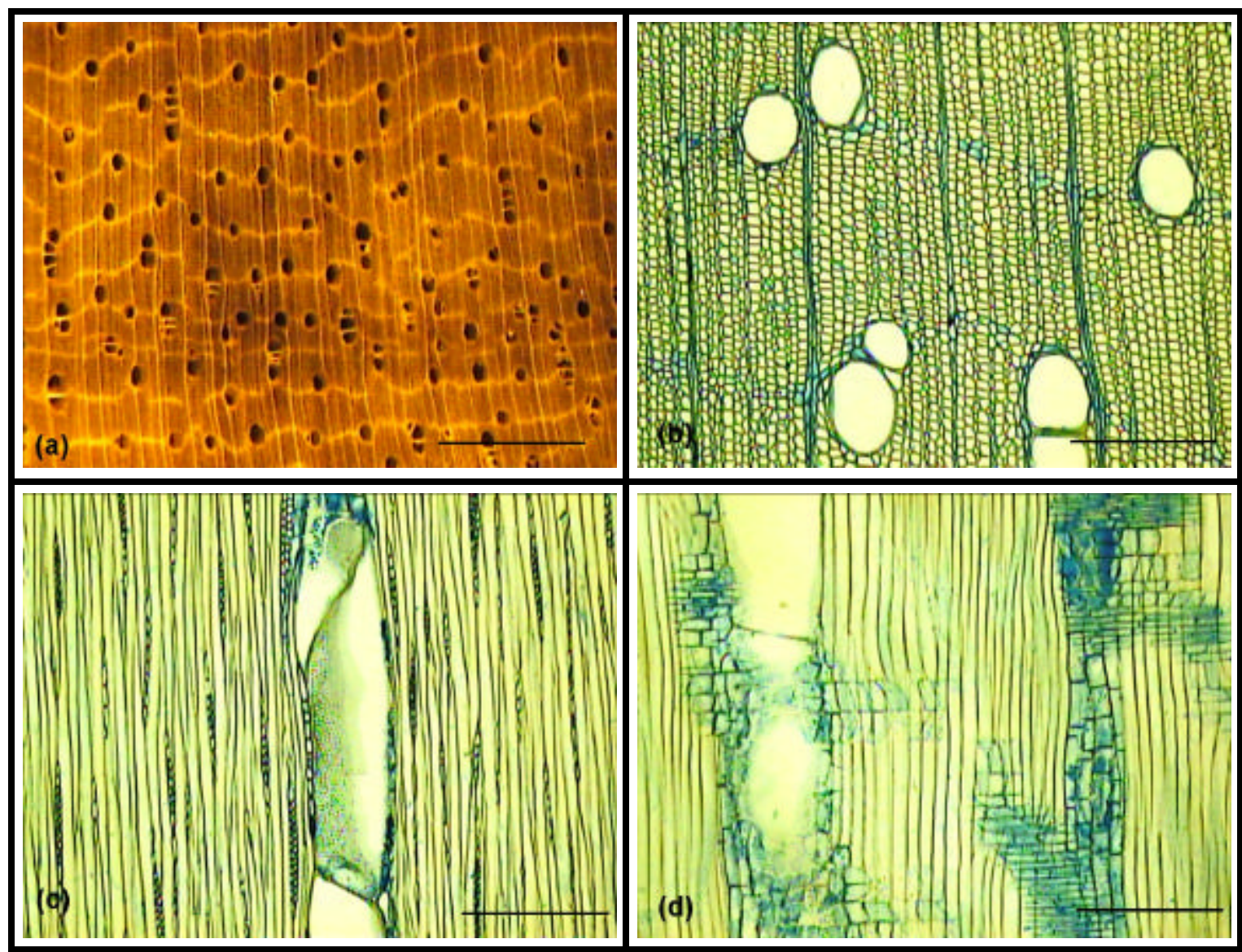

Figura 16 - Croton lechleri - (a) seção transversal (10x), (b) seção transversal (50x), (c) seção longitudinal tangencial (50x), (d) seção longitudinal radial do lenho (50x). Escala de barra "a" $=1$ mm, "b", "c" e "d" = $250 \mu \mathrm{m}$ 

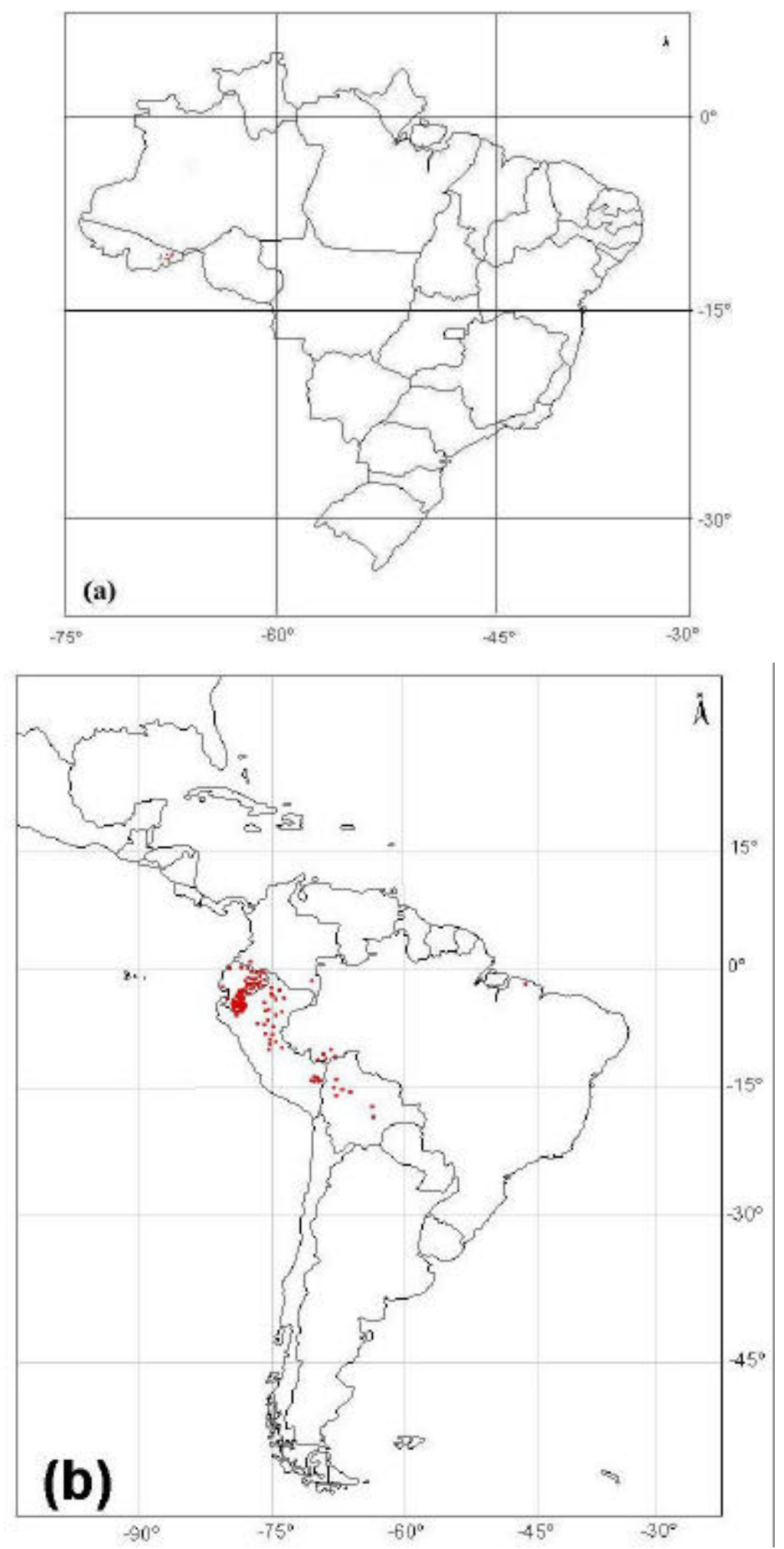

Figura 17 - Distribuição geográfica de Croton lechleri no Brasil (a) e na América Latina (b) 


\subsection{Croton matourensis Aubl.}

Família botânica: Euphorbiaceae

Publicado em: Histoire des plantes de la Guiane Françoise 2: 879, t. 338. 1775. \{Hist. Pl. Guiane

Tipo: T: Aublet s.n., French Guiana (BM).

Sinônimo botânico: Croton sericeus Lam. \{Encycl.: 2: 210. 1786\}

Nomes vulgares: Brasil: Acre: velame; Amazonas: dima, dima-branca, dyma, jima, maravôvoia, maravuvuia; Maranhão: kurupyý, maioba; Pará: arikena, caroatá, cascagaivota, dima, ingui-ou-dou, marabubuaia, maravuvuia, muiravuvuia, taki-taki. Bolívia: aliso branco. Colômbia: erarikague, ojo de sadina. Peru: atadijo, auca atadijo, yura, yurac siprana.

\subsubsection{Caracterização dendrológica}

Árvore de porte grande, encontra-se na floresta primária e na secundária; de 8$30 \mathrm{~m}$ de altura, 20-40 cm de diâmetro; copa aberta alongada; fuste cilíndrico; casca externa cinza-prateada ou cinza-avermelhada, de aparência fissurada, nos exemplares mais novos com cicatrizes como meia lua; casca interna branca e avermelhada, de 8$12 \mathrm{~mm}$ de espessura, textura fibrosa; secreta lentamente um látex vermelho, de sabor adstringente, viscoso e em pequena quantidade. Ramos terminais de seção poligonat irregular, canicular, bege-esverdeado; folhinhas terminais conduplicadas; com pêlos escamo-estrelados densos, cor bege ou bege-amarelado. Folhas simples e alternas; elípticas ou elíptico-oblongas ou elíptico-abovados; de 3-8 cm de largura e 6-24 cm de comprimento; bordo inteiro ou levemente sinuoso; ápice agudo, mucronado ou levemente acuminado; base aguda ou agudo-redonda; nervura pinatinervada reta a retaoblíqua, com 26-28 pares de nervuras, densamente pubescentes; consistência cartácea; cor verde, levemente brilhante na superfície adaxial, glabra, só com pequenas excrescências cerosas e glândulas microscópicas na superfície toda; cor verde claro ou bege-verde ou bege-creme na parte abaxial, sempre mais escuros nas nervuras, pêlos em alta densidade, do tipo escamo-estrelado, na base 2 (1-4) glândulas de cores contrastantes. Pecíolo estriado e caniculado, de 0,4-4,2 $\mathrm{cm}$ de comprimento e 3-5 $\mathrm{mm}$ de 
diâmetro, com pêlos escamo-estrelados, bege-verdosos. Os pêlos apresentam 1-2 glândulas na parte central. Estípulas foliares, lineares, persistentes, com pêlos. Inflorescências terminais ou sub-terminais, tipo racimo, monóico; flôres masculinas abundantes na parte superior e, as femininas na base; de $15-30 \mathrm{~cm}$ de comprimento. Flores unissexuais, com brácteas lanceoladas. Flores masculinas de 6-8 mm de comprimento; cálice gamosépalo, cupuliforme, com 5 dentes, totalmente revestidos com pêlos escamo-estrelados; corola com 5 pétalas, cremes ou branco-cremes, elíptica ou elíptico-abovada, trinervada, com pêlos semi-longos em toda a superfície e margem da lâmina e mesmo assim cobertos com pêlos escamo-estrelados; androceu com 10 estames livres, com pêlos semi-longos na base dos filetes, insertos sobre um disco-glandular septado, de até $8 \mathrm{~mm}$ de comprimento, com anteras bitecas de 0,8-1,2 $\mathrm{mm}$ de comprimento e deiscência longitudinal. Flores femininas de $8-9 \mathrm{~mm}$ de comprimento; cálice gamosépalo com 5 dentes alongados, totalmente revestido com pêlos escamoestrelados; corola com 5 pétalas, creme ou branco-creme, elíptica ou elíptico-abovada, trinervada, com pêlos semi-longos em toda a superfície e margem da lâmina e cobertos com pêlos escamo-estrelados; gineceu verde, ovário súpero, com 3 carpelos, 3 lóculos, cobertos com pêlos escamo-estrelados, vários estiletes. Fruto seco, tipo tricoco, de 3-5 mm diâmetro. Semente em torno de 2 mm de comprimento, globosa (Figuras 18 e 19).

\subsubsection{Caracterização anatômica do lenho}

Cerne indistinto do alburno, de cor esbranquiçada a branco-amarelada, brilho acentuado, odor e gosto imperceptíveis, densidade de massa baixa, resistência ao corte macia, grã direita, textura média. Camadas de crescimento pouco distintas, demarcadas pela espessura da parede celular das fibras. Vasos visíveis a olho nu; difusos; arranjo radial; solitários $(85,71 \%)$ e múltiplos $(14,29 \%)$, grupos de 2-3, raro 4, frequiência 38/mm²; diâmetro tangencial do lume 86,64-213,28 $\mu \mathrm{m}$, média 166,96 $\mu \mathrm{m}$ e desvio padrão 36,86 e forma arredondada; comprimento 159,96-1.053,07 $\mu \mathrm{m}$, média 716,49 $\mu \mathrm{m}$ e desvio padrão 195,73; apêndices curtos, menor a 1/3 do comprimento do vaso e em ambas extremidades; placas de perfuração simples; depósitos distintos; pontoações intervasculares, areoladas, alternas, predominantemente poligonais e poucos 
arredondadas, abundantes, ornamentação ausente, diâmetro tangencial 4,67-8,45 $\mu \mathrm{m}$, média $6,66 \mu \mathrm{m}$ e desvio padrão 0,92 ; pontoações raio-vasculares areoladas, alternas, arredondadas, poucas, diâmetro tangencial 3,19-6,03 $\mu \mathrm{m}$, média 4,68 $\mu \mathrm{m}$ e desvio padrão 0,79; pontoações parênquimo-vasculares semelhantes às intervasculares. Fibras com pontoações distintamente areoladas maiores de $3 \mu \mathrm{m}$; curtas, comprimento 950$1.410 \mu \mathrm{m}$, média $1.195 \mu \mathrm{m}$ e desvio padrão 150; largura 25-40,63 $\mu \mathrm{m}$; espessura da parede delgada com lume de 12,50-28,13 $\mu \mathrm{m}$; pontoações alternas, arredondadas, abundantes raras na seção radial, com diâmetro tangencial 2,22-5,26 $\mu \mathrm{m}$, média 3,74 $\mu \mathrm{m}$ e desvio padrão 0,64. Parênquima axial visível a olho nu; paratraquel aliforme e linear confluente e apotraqueal difuso; células do tipo seriado. Parênquima radial (raios) visível a olho nu, unisseriados $(66,67 \%)$ e multisseriados $(33,33 \%)$ geralmente 2 séries; altura 3,9-10,85 mm, média 6,78 $\mathrm{mm}$ e desvio padrão 3,12; freqüência 8-10/mm, média 8,8/mm e desvio padrão 1,03; heterocelulares, com 3 fileiras $(16,46 \%)$ de células eretas no extremo superior, no centro 11 fileiras $(67,08 \%)$ de células procumbentes e 3 fileiras $(16,46 \%)$ de células eretas no extremo inferior; com 5-23 linhas de células; largura variando de 13,33-26,66 $\mu$ m [Tabela 3 (Anexo B) e Figura 20].

\subsubsection{Distribuição geográfica}

Esta espécie encontra-se amplamente distribuída na Amazônia e, em forma localizada na América Central (Panamá), entre as faixas latitudinais (08³0’00”N 17²2’06”S), longitudinais (4458'00”W-80²5”00”W) e altitudinais (7-1.010 m) [Tabela 5 (Anexo B)]. Encontra-se na Bolívia, Brasil, Colômbia, Equador, Guiana, Guiana Francesa, Panamá, Peru, Suriname e Venezuela. No Brasil nos Estados do Acre, Amazonas, Maranhão, Mato Grosso, Pará, Rondônia e Roraima. No Acre nos municípios de Cruzeiro do Sul, Porto Walter, Rio Branco, Rodrigues Alves e Tarauacá (Figura 21). Esta espécie pode ser encontrada em florestas secundárias antigas e em florestas primárias. 


\subsubsection{Status ou situação populacional}

Esta espécie foi incluída na categoria LC (comum e abundante, fora de perigo) pela sua abundância nas áreas de coleta e pelo extenso material revisado nos herbários. Apesar de se encontrar em áreas expostas é considerada de boa qualidade pelos proprietários rurais, mantendo-a até sua maturidade [Tabela 7 (Anexo B)]. Não há registros de sua presença em unidades de conservação. 

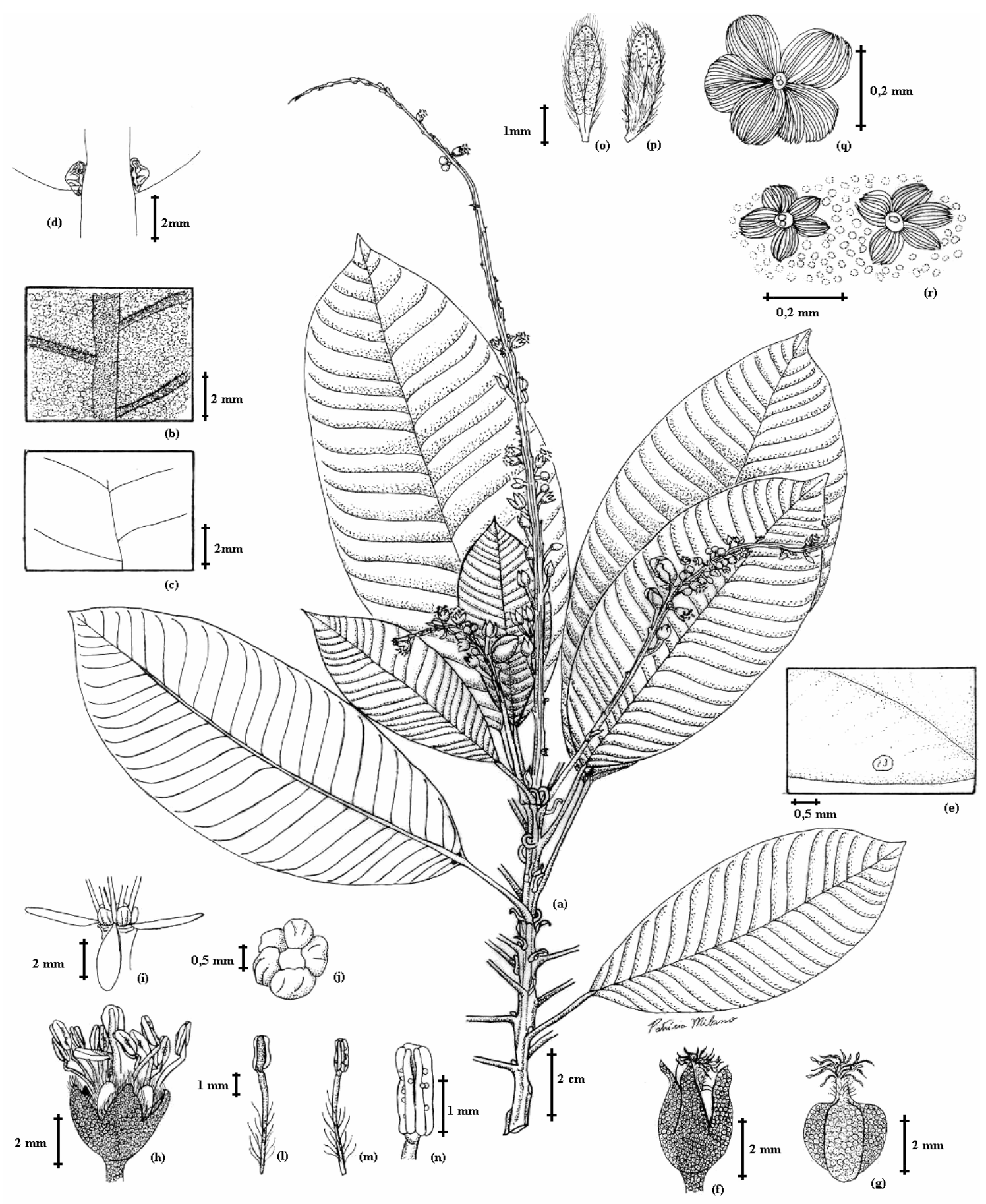

Figura 18 - Croton matourensis Aubl. - ramo terminal com inflorescência (a), pubescência da folha face abaxial (b), pubescência na face adaxial (c), glândulas na base da folha face adaxial (d), glândulas na superfície da face adaxial (e), flor feminina e gineceu não fecundado (f, g), flor masculina (h), disco glandular da flor masculina $(i, j)$, estames e antera $(1, m, n)$, pétalas face abaxial e adaxial da flor masculina (o, p), pêlo da flor (q), pêlos da folha (r) 

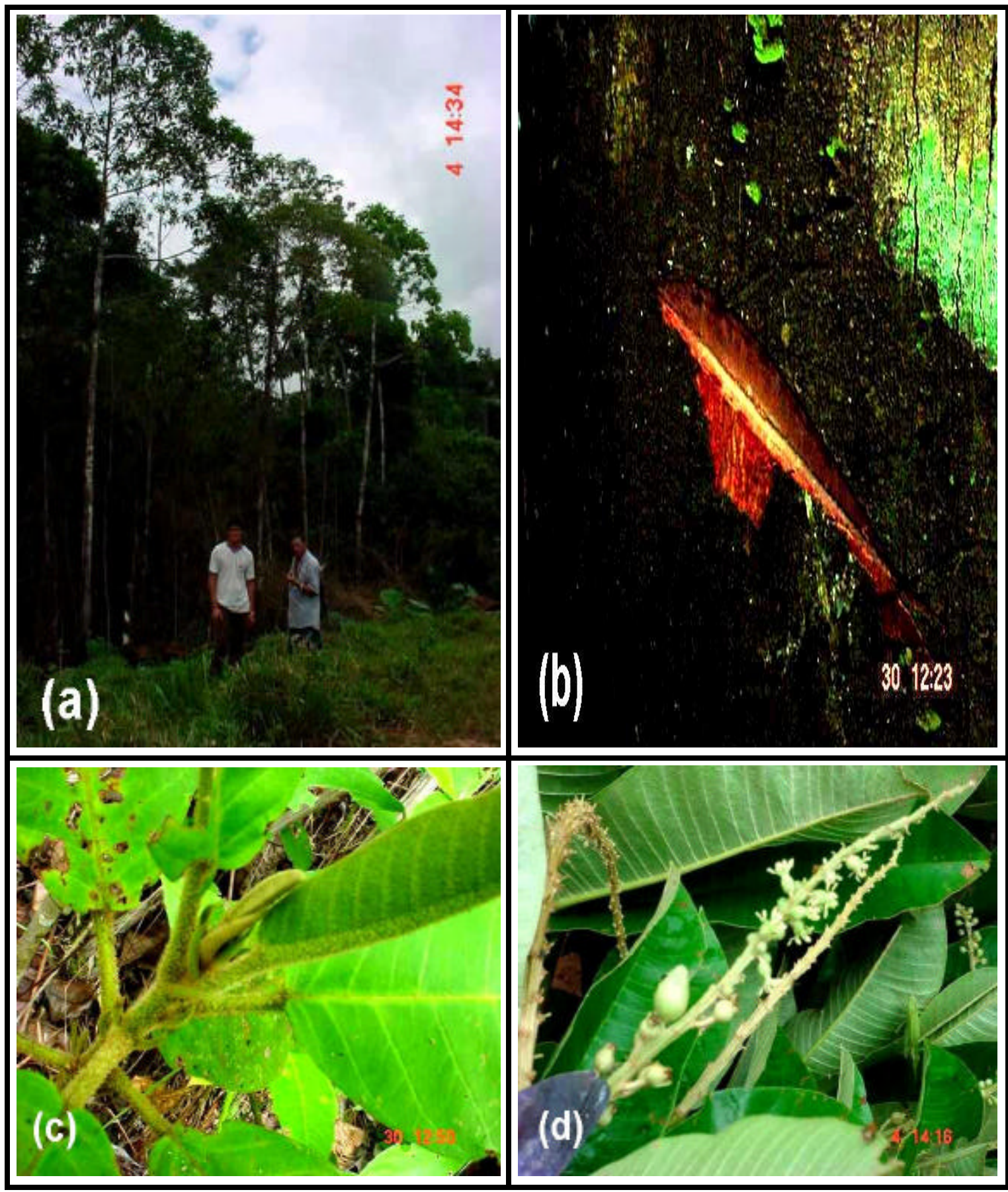

Figura 19 - Croton matourensis - (a) árvores em pé, (b) casca externa e interna, (c) ramo terminal da regeneração natural com detalhe de estípula e pêlos, (d) inflorescência e frutos 

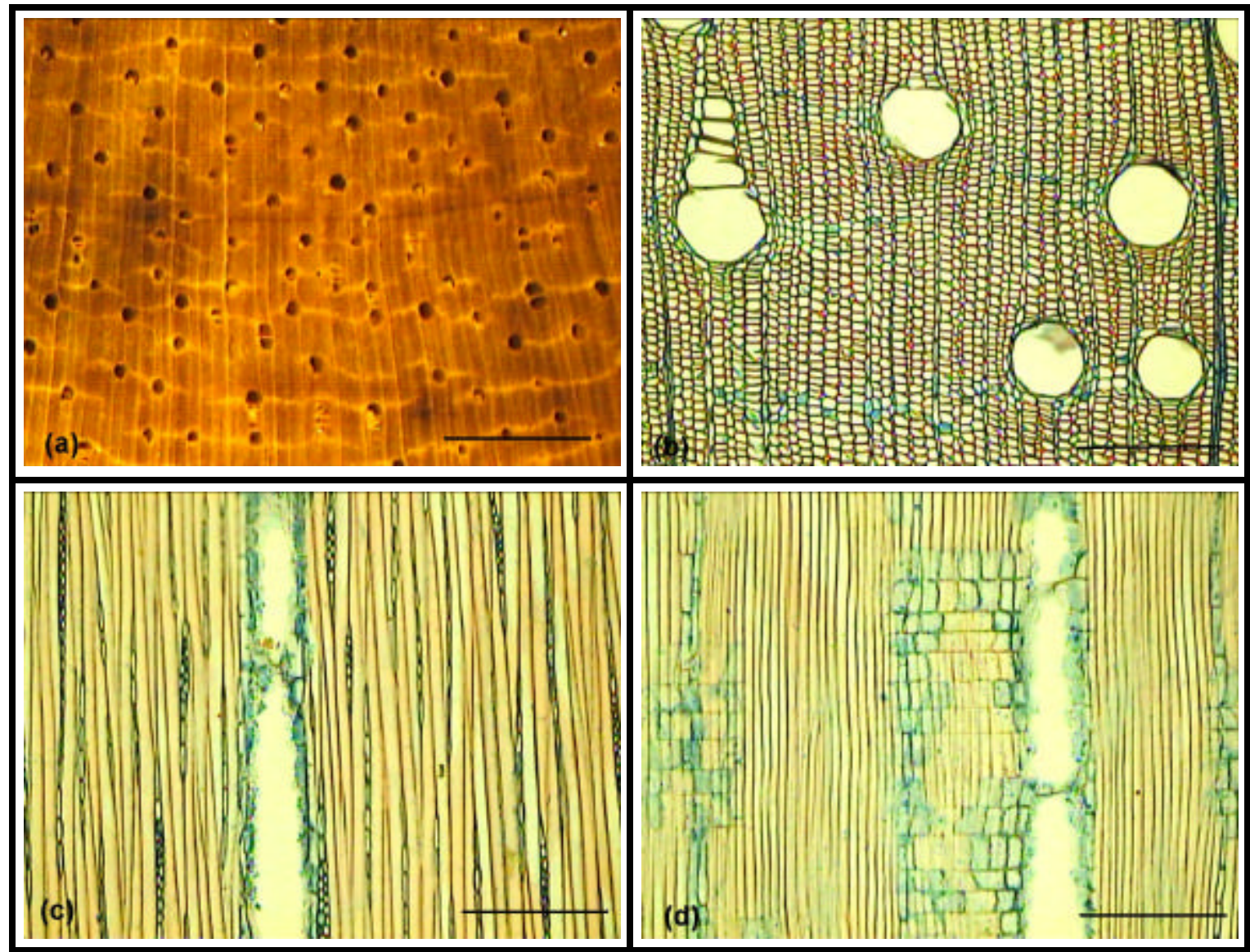

Figura 20 - Croton matourensis - (a) seção transversal (10x), (b) seção transversal (50x), (c) seção longitudinal tangencial (50x), (d) seção longitudinal radial do lenho (50x). Escala de barra "a" = $1 \mathrm{~mm}$, , b", "c" e "d" = $250 \mu \mathrm{m}$ 

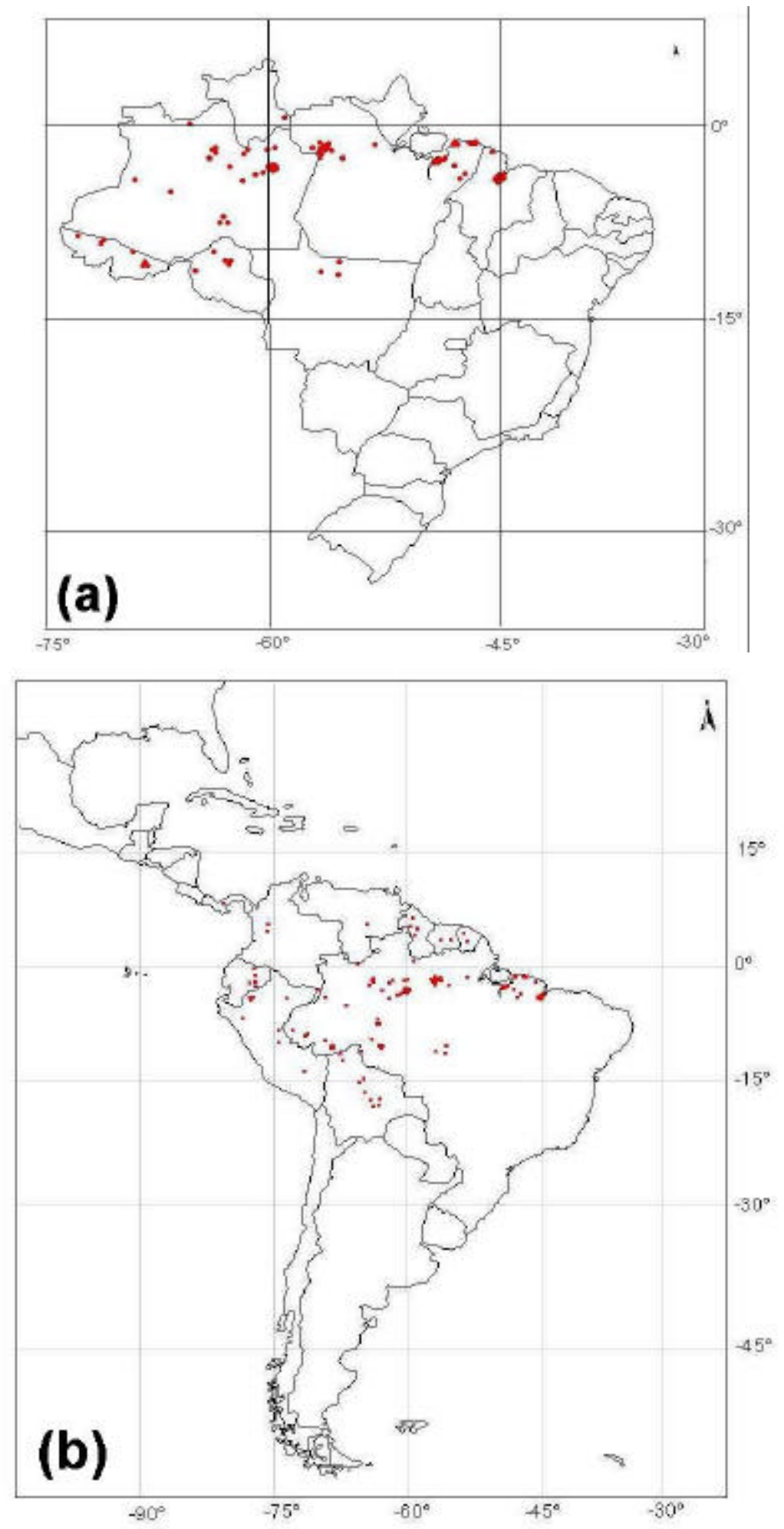

Figura 21 - Distribuição geográfica de Croton matourensis no Brasil (a) e na América Latina (b) 


\subsection{Croton palanostigma Klotzsch}

Família botânica: Euphorbiaceae

Publicado em: London Journal of Botany 2: 48. 1843. \{London J. Bot. ; BPH 534.12\}

Tipo: Martius 14258, Jan, Brazil (M).

Sinônimo botânico: Croton benthamianus Müll. Arg. \{Fl. Bras. 11(2): 105. 1873\}; Oxydectes palanostigma Kuntze \{Revis. Gen. Pl. :2: 612. 1891\}.

Nomes vulgares: Brasil: Amazonas: balsa-rana, croton, marmeleiro, murucututu; Mato Grosso: marmeleiro; Roraima: maravuvuiarana. Bolívia: sangre de grado. Peru: pashnahuachana, purma caspi, sangre de grado, señora vara, shambo quiro.

\subsubsection{Caracterização dendrológica}

Arbusto, arboreta ou árvore; próprios de florestas secundárias médias, heliófitas; de 4-25 m de altura, 15-25 cm de diâmetro; copa aberta, a maneira de guardasol; fuste cilíndrico ou cilíndrico-irregular; casca externa marrom-cinza ou cinza, com manchas verde-azul pelos líquenes, de aparência anelada, pelas cicatrizes semicirculares; casca interna branco-creme ou creme, de 3-4 $\mathrm{mm}$ de espessura, textura fibro-laminar; secreta abundante látex vermelho, de sabor adstringente e viscoso. Ramos terminais de seção poligonal, marrom; folhinhas terminais conduplicadas; com pêlos ferruginosos estrelados, densos. Folhas simples e alternas; ovadas, ovado-elípticas ou elípticoirregulares, às vezes lobadas, pelo geral apresenta polimorfismo foliar; de 7-14 cm de largura e 11-18 cm de comprimento; bordo levemente sinuoso; ápice agudo; base obtusa, redonda ou obtusa-irregular; nervura pinatinervada oblíqua ou subpalmatinervia, com 58 pares de nervuras; consistência papirácea ou cartácea; cor verde pálido na superfície adaxial, com pêlos sobre a superfície toda e glândulas microscópicas com bastante regularidade na axila das nervuras; na superfície abaxial verde mais claro, com abundantes pêlos estrelados, esbranquiçados, sempre mais abundantes nas nervuras, base da lâmina conspicuamente 2 glândulas subalternas. Pecíolo levemente caniculado, de 2-8 cm de comprimento e 3-5 mm de diâmetro, com pêlos estrelados de cor marrom. Estípulas foliares, deltóides, com pêlos estrelados e caducas. Inflorescências terminais ou sub-terminais, tipo racimo, monóico; com flores 3-5 fasciculados; flores masculinas 
abundantes na parte superior e, as femininas escassas na base; de 20-30 cm de comprimento. Flores unissexuais, com brácteas minúsculas oblongas. Flores masculinas de 7-8 mm de comprimento; cálice gamosépalo, cupuliforme, com 5 lóbulos triangulares pontiagudos, totalmente revestido com pêlos escamo-estrelados; corola com 5 pétalas, branca ou branco-cremes, espatulada com uma unha longa onde se dispõem pêlos hirsutos semi-longos, e na margem da lâmina e na superfície toda com pêlos mais curtos e, ademais, cobertos com pêlos escamo-estrelados; androceu com 10 estames livres, com pêlos curtos na base dos filetes, insertos sobre um disco-glandular septado, de até $5 \mathrm{~mm}$ de comprimento, conetivo carnoso, anteras bitecas de 1,2-3 $\mathrm{mm}$ de comprimento e deiscência longitudinal. Flores femininas de 6-7 $\mathrm{mm}$ de comprimento; cálice gamosépalo, campanulado, com 5 lóbulos redondo-acuminado, totalmente revestido com pêlos escamo-estrelados; corola com 5 pétalas, branca ou branco-creme, espatulada com uma unha longa onde se dispõem pêlos hirsutos semi-longos, e na margem da lâmina e na superfície toda com pêlos mais curtos e, ademais cobertos com pêlos escamoestrelados; gineceu verde, ovário súpero, com 3 carpelos, 3 lóculos, cobertos com pêlos escamo-estrelados, 3 estiletes divididos em estigmas de forma dendriforme. Os pêlos escamo-estrelados com 3-5-6 glândulas. Fruto cápsula do tipo tricoco, até $4 \mathrm{~mm}$ de diâmetro e $6 \mathrm{~mm}$ de comprimento, abrindo em 3 cocos bivalves, cobertos de pêlos idênticos ao ovário. Semente 1 por lóculo (Figuras 22 e 23).

\subsubsection{Caracterização anatômica do lenho}

Cerne indistinto do alburno, de cor esbranquiçado a branco-acinzado, brilho acentuado, odor e gosto imperceptíveis, densidade de massa média, resistência ao corte macia, grã direita, textura média. Camadas de crescimento pouco distintas, demarcadas pela espessura da parede celular das fibras. Vasos visíveis a olho nu; difusos; arranjo radial; solitários $(35,71 \%)$ e múltiplos $(64,29 \%)$, grupos de 2-3 ou 4, frequiência 418/mm²; diâmetro tangencial do lume 93,31-159,96 $\mu \mathrm{m}$, média 121,30 $\mu \mathrm{m}$ e desvio padrão 26,99 e forma arredondada; comprimento 466,55-733,15 $\mu \mathrm{m}$, média 543,86 $\mu \mathrm{m}$ e desvio padrão 84,02; apêndices curtos, menores a $1 / 3$ do comprimento do vaso e em ambas extremidades; placas de perfuração simples; depósitos distintos; pontoações 
intervasculares aeroladas, alternas, predominantemente poligonais e poucos arredondadas, abundantes, ornamentação ausente, diâmetro tangencial 3,98-7,65 $\mu \mathrm{m}$, média $5,23 \mu \mathrm{m}$ e desvio padrão 1,88; pontoações raio-vasculares areoladas, alternas, arredondadas, pouco abundantes, diâmetro tangencial 1,99-4,84 $\mu \mathrm{m}$, média 3,63 $\mu \mathrm{m}$ e desvio padrão 0,63 ; pontoações parênquimo-vasculares semelhantes às intervasculares. Fibras com pontoações simples e areoladas muito pequenas menores de $3 \mu \mathrm{m}$; muito curtas a curtas, comprimento 780-1.300 $\mu \mathrm{m}$, média 1,120 $\mu \mathrm{m}$ e desvio padrão 170; largura 15,63-28,13 $\mu \mathrm{m}$; espessura da parede delgada com lume de 9,38-18,75 $\mu \mathrm{m}$; pontoações alternas, arredondadas, abundantes, poucas na seção radial, com diâmetro tangencial $0,56-1,42 \mu \mathrm{m}$, média $0,97 \mu \mathrm{m}$ e desvio padrão 0,27 . Parênquima axial visível sob lente (10x); paratraqueal escasso de tipo aliforme, tendendo a formar confluência e também apotraqueal difuso. em faixas estreitas ou linhas com menos de 3 células de largura; células de tipo seriado. Parênquima radial (raios) visível a olho nu, unisseriado $(56,25 \%)$ e multisseriado $(43,75 \%)$ geralmente 2 séries; altura 3,25-8,46 $\mathrm{mm}$, média 5,37 mm e desvio padrão 2,59; frequiência 7-10/mm, média $8,6 / \mathrm{mm}$ e desvio padrão 1,17; heterocelulares, com 5 fileiras $(23,53 \%)$ de células eretas na extremidade superior, no centro 12 fileiras $(60,78 \%)$ de células procumbentes e 3 fileiras $(15,69 \%)$ de células eretas na extremidade inferior; com 425 linhas de células; largura variando de 20-39 $\mu \mathrm{m}$ [Tabela 3 (Anexo B) e Figura 24].

\subsubsection{Distribuição geográfica}

Esta espécie se encontra amplamente distribuída na Amazônia, entre as faixas

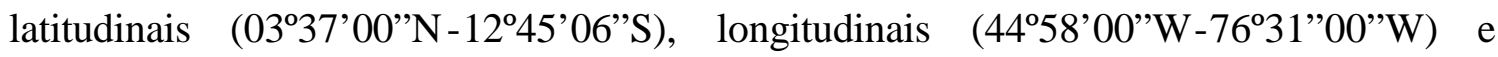
altitudinais (0-1015 m) [Tabela 5 (Anexo B)]. É registrada na Bolívia, Brasil, Colômbia, Guiana Francesa, Peru e Venezuela. No Brasil nos Estados do Acre, Amazonas, Maranhão, Mato Grosso, Pará, Rondônia e Roraima. No Acre nos municípios de Cruzeiro do Sul e Mâncio Lima (Figura 25). Essa espécie pode ser encontrada nas florestas secundárias abertas e com muita freqüência nas margens dos rios. 


\subsubsection{Status ou situação populacional}

Esta espécie foi incluída na categoria CR (perigo crítico) pela sua escassez nas áreas de amostragem. É praticamente uma espécie muito rara no Acre, confirmado nos trabalhos de campo, embora sejam abundantes em outras áreas da Amazônia. Encontrase em áreas expostas, com o risco de exploração para o aproveitamento do látex, com propriedades medicinais semelhantes as do Croton lechleri [Tabela 7 (Anexo B)]. Desconhece-se a sua presença em unidades de conservação. 

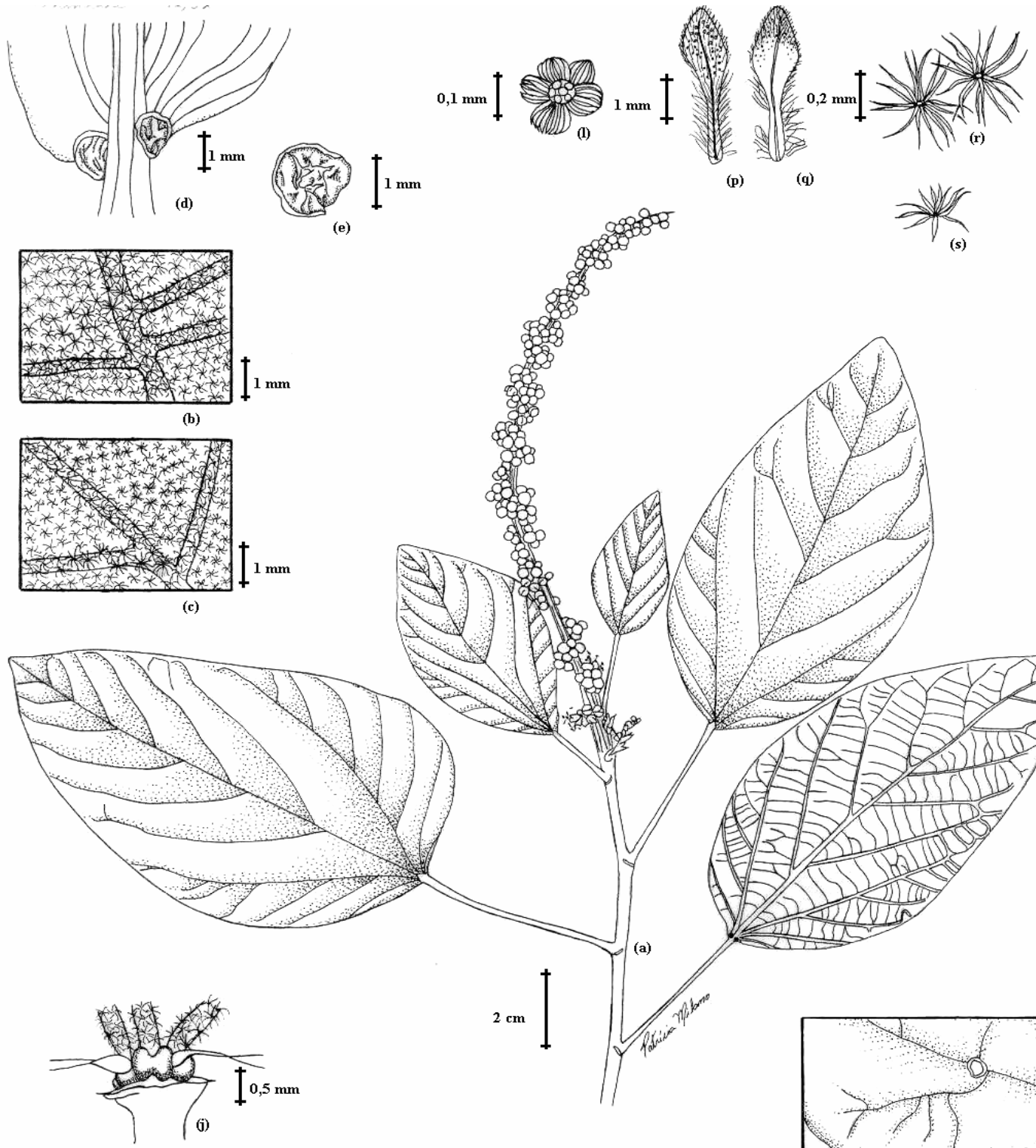


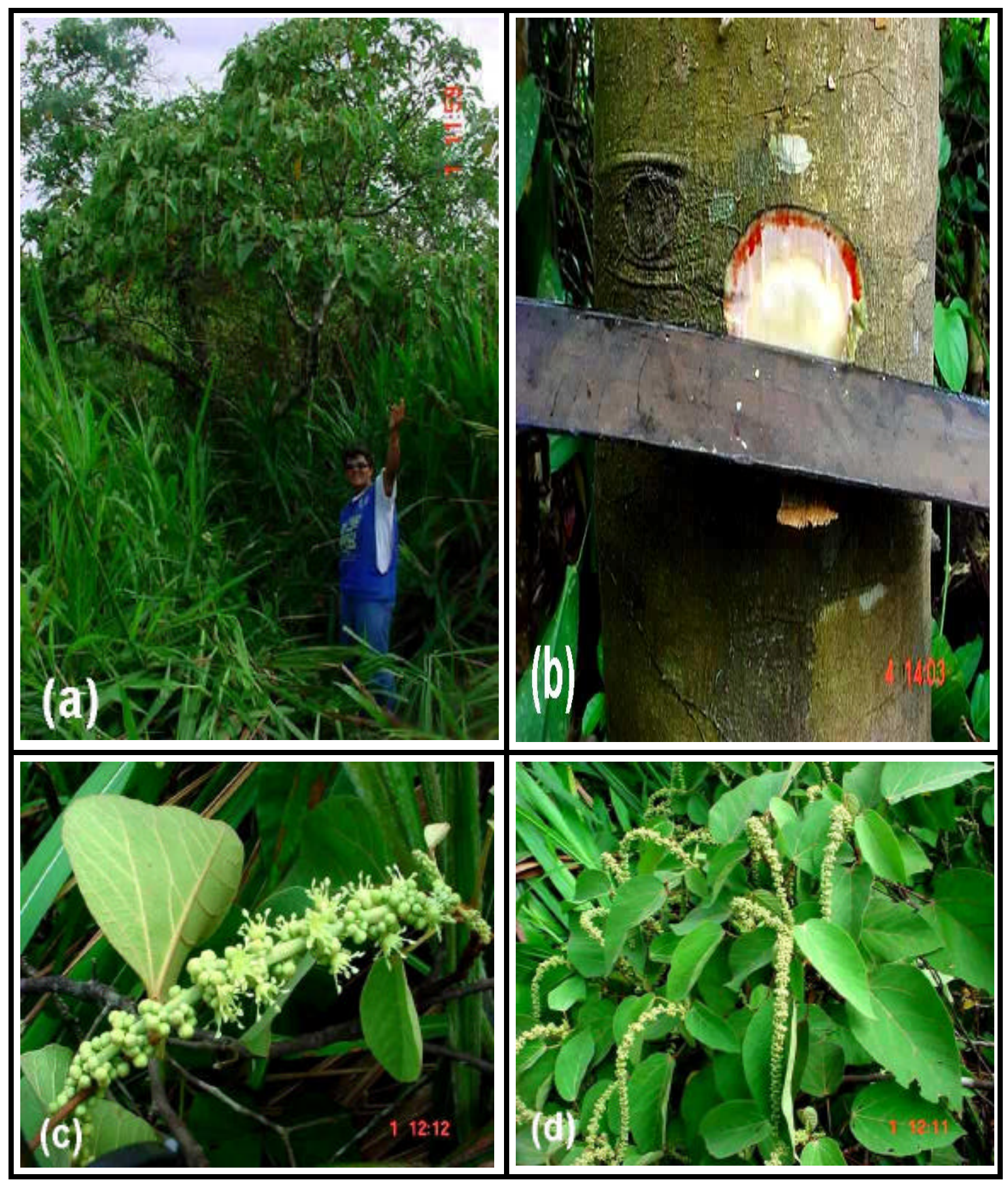

Figura 23 - Croton palanostigma - (a) árvore em pé, (b) casca externa e interna, (c) inflorescência com flores masculinas, (d) ramo terminal com inflorescências imaturas 


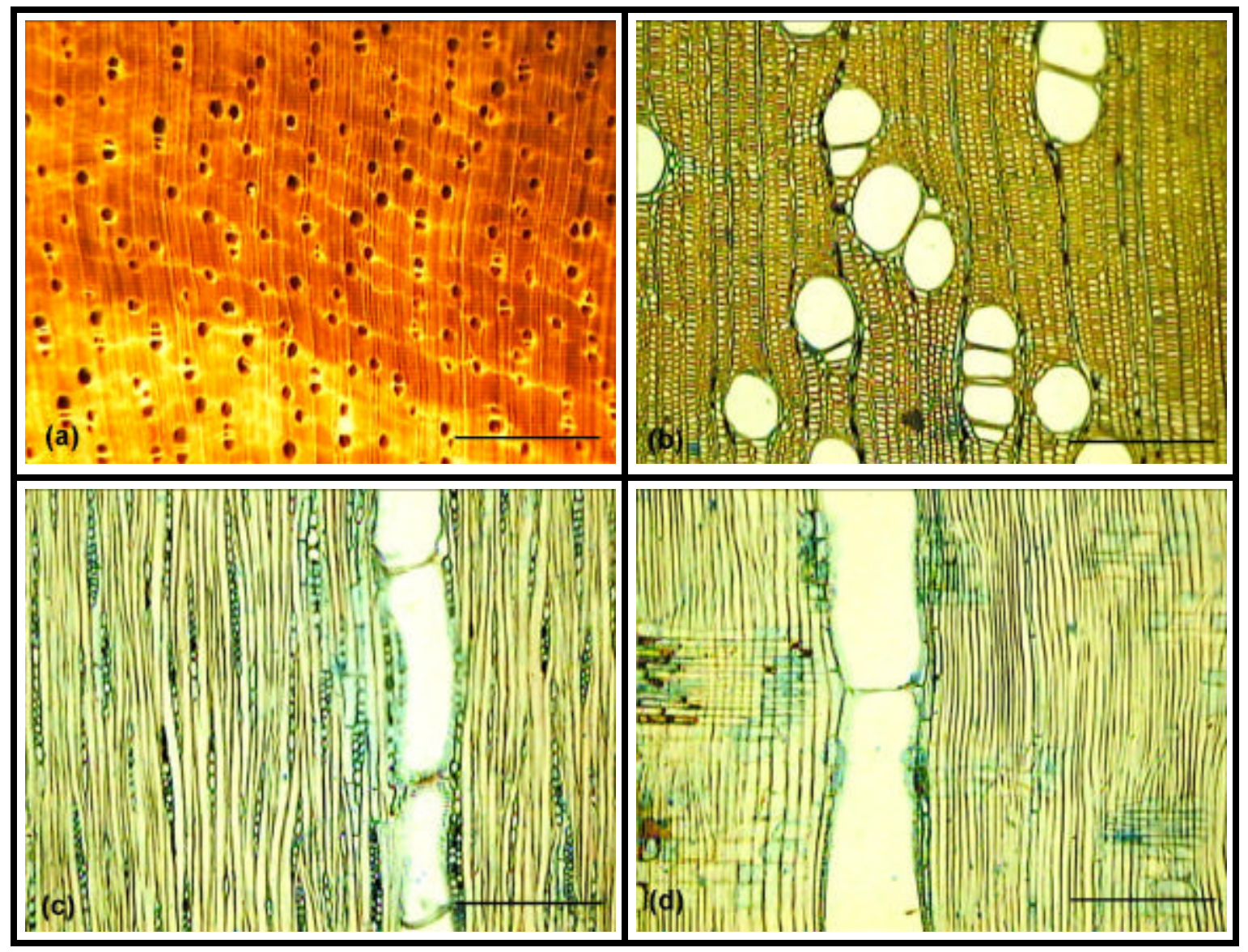

Figura 24 - Croton palanostigma - (a) seção transversal (10x), (b) seção transversal (50x), (c) seção longitudinal tangencial $(50 \mathrm{x})$, (d) seção longitudinal radial do lenho (50x). Escala de barra "a" = $1 \mathrm{~mm}$, "b", "c" e "d"= $250 \mu \mathrm{m}$ 

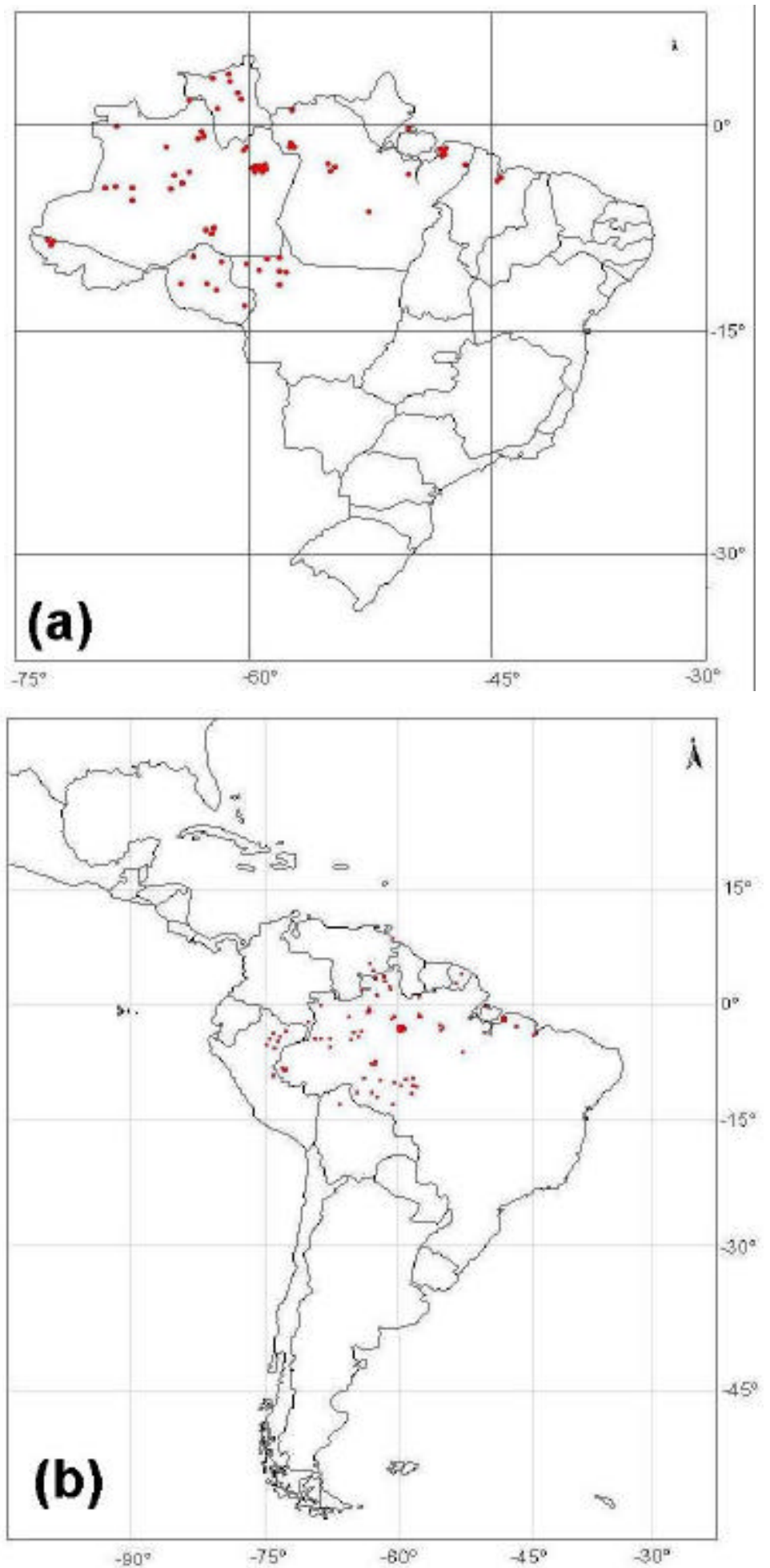

Figura 25 - Distribuição geográfica de Croton palanostigma no Brasil (a) e na América Latina (b) 


\section{4 .7 Uncaria guianensis (Aubl.) J.F. Gmel.}

Família botânica: Rubiaceae

Publicado em: Systema Naturae editio decima tertia, aucta, reformata 2: 370. 1791. \{Syst. Nat.

Tipo: T: Aublet s.n, 1762-1764, French Guiana (BM, P-r 8: 270).

Sinônimo botânico: Nauclea aculeata (Willd.) Willd. \{Sp. Pl.: 1: 929. 1798.\} Ourouparia guianensis Aubl. \{Hist. Pl. Guiane:1: 177, t. 68. 1775.\}; Uncaria aculeata Willd. \{Delect. Opusc. Bot. 2: 200. 1793\}; Uncaria spinosa Raeuschel \{Nomencl., ed. 3 55. 1797\}

Nomes vulgares: Brasil: Acre: ansou-de-londra, cipô, cipó-anzol-de-londra, espara-aí, esperái, unha-de-gato; Amapá: jupindá, mão-de-gato; Amazonas: espera-aí, unha-degato; Maranhão: maracuçumé, paruá-cipó; Mato Grosso: jupindá, unha-de-onça; Pará: cuerussu, jupídá-do-vermelho, pau-d'arco, unha-de-gato; Rondônia: unha-de-lontra. Bolívia: cacatao, misijuni, unha-de-gato. Peru: ancajsillo, ancauacu, auri huasca, garabata, garabata casha, garabato, garabato colorado, garabatocasha, huarinhuasca, jijyúwamyuúho, kug kuukjagki, tambo huasca, toroñ, uña de gato, uña de gavilán, unganangui, yamayakat. Suriname: sipaliwini. Venezuela: uña de gavilán.

\subsubsection{Caracterização dendrológica}

Liana, lenhosa ou arbusto rasteiro, típico em florestas secundárias, pertence ao grupo ecológico das heliófitas efêmeras; pode alcançar até $20 \mathrm{~m}$ de comprimento; $10 \mathrm{~cm}$ de diâmetro; caule cilíndrico; casca externa marrom, de aparência fissurada e ritidoma persistente; casca interna de cor ouro-pardo ou vermelho-amarelo, textura laminarfibrosa, com o corte do lenho apresenta uma secreção aquosa de consistência fluída e de sabor adstringente. Ramos terminais de seção quadrada, verde-avermelhados, geralmente avermelhados, glabros, com folhinhas terminais em forma de lança. Folhas simples, opostas e dísticas; elípticas ou elíptico-oblongas; de 3,8-8,5 cm de largura; 6,5$18 \mathrm{~cm}$ de comprimento; margem ligeiramente sinuada; ápice agudo e ligeiramente acuminado; base aguda ou aguda-redonda; de consistência membranosa; nervura pinatinérvia curva, com 6-7 pares de nervuras, geralmente subalternos; cor verde 
brilhante na parte adaxial, glabro, sempre com manchas aparentemente de ferrugem; na superfície abaxial verde-avermelhado. Pecíolo de 6-20 mm de comprimento e 1,5-1,8 mm de largura, glabro. Estípulas interpeciolares, geralmente caducas, em forma de lança, de 6-12 mm de comprimento e 3,5-6 $\mathrm{mm}$ de largura; apresentam um par de espinhos, opostos, fortemente recurvados, em forma de gancho, lenhosos de 4-24 mm de comprimento e 3-6 mm de largura. Inflorescências terminais ou axilares, compostas em racimos ou cimas de capítulos, totalmente esféricos; de $8-22 \mathrm{~cm}$ de comprimento; os capítulos com um diâmetro de 1,3-4,5 cm; pedúnculo glabro, de 20-35 mm de comprimento e 1,5-2,0 mm de largura, seção circular. Flores bissexuais e actinomorfas, com hipanto, infundibuliforme, pediceladas; pedicelo de $4 \mathrm{~mm}$ de comprimento. Cálice gamossépalo, tubular ou tubular-campanulado, de 4-10 mm de comprimento e 2,5-4 mm de diâmetro; com 5 lóbulos de forma triangular, tomentoso no exterior e glabro no interior. Corola gamopétala, com 5 lóbulos redondos e reflexos, mais compridos que largos, de 6-12 mm de comprimento e 2,5-4 mm de largura, com ápice redondo, cor vermelho-alaranjado, pubescência na parte exterior superior (1/3) com pêlos vilosos, o resto glabro (2/3 inferior), parte interior glabro. Androceu com 5 estames subsésseis, adnatos a garganta da corola, alternipétalas, com filetes curtos; anteras oblongas, dorsifixas, com base divergente, de $2-3 \mathrm{~mm}$ de comprimento e 0,5-2 $\mathrm{mm}$ de largura. Gineceu com 1 pistilo com estigma elipsóide de 1,5 $\mathrm{mm}$ de comprimento, estilo linear, excerto e glabro, até $2 \mathrm{~cm}$ de comprimento; ovário ínfero, 2-carpelar, 2-locular, sincárpico e placentação axilar. Fruto seco, deiscente, tipo cápsula de forma elipsóide, de 8-13 mm de comprimento e 3-7 mm de largura; deiscência longitudinal septicida, com cálice persistente e acrescente, com numerosas sementes. Sementes fusiformes com asas membranosas, um extremo linear e o outro bilinear, de 5-7 $\mathrm{mm}$ de comprimento e 0,6-1,2 mm de largura (Figuras 26 e 27).

\subsubsection{Caracterização anatômica do lenho}

Cerne indistinto do alburno, de cor vermelho-amarelado, bege- avermelhado ou rosa-avermelhado, brilho moderado, odor imperceptível, gosto levemente amargo, densidade de massa média/baixa, resistência ao corte moderadamente dura, grã direita, 
textura média/grossa. Camadas de crescimento pouco distintas, demarcadas pela espessura da parede celular das fibras. Vasos visíveis a olho nu; difusos; arranjo radial; solitários $(64,29 \%)$ e múltiplos $(35,71 \%)$ de 2-3 células, frequiência 3-13/mm²; diâmetro tangencial do lume 106,64-453,22 $\mu \mathrm{m}$, média 308,70 $\mu \mathrm{m}$ e desvio padrão 91,48 e forma arredondada; comprimento 293,26-826,46 $\mu \mathrm{m}$, média 598,96 $\mu \mathrm{m}$ e desvio padrão 125,61; apêndices curto, menor a $1 / 3$ do comprimento do vaso e em ambas extremidades; placas de perfuração simples; depósitos distintos; pontoações intervasculares areoladas, alternas, arredondadas, abundantes, ornamentação ausente, diâmetro tangencial 4,25-7,11 $\mu \mathrm{m}$, média 5,56 $\mu \mathrm{m}$ e desvio padrão 0,36 ; pontoações raio-vasculares, areoladas, alternas, arredondadas, abundantes, diâmetro tangencial 4,12$6,57 \mu \mathrm{m}$, média de 5,67 $\mu \mathrm{m}$ e desvio padrão de 0,75 ; pontoações parênquimo-vasculares semelhantes às intervasculares. Fibras com pontoações distintamente areoladas maior de $3 \mu \mathrm{m}$; curtas a longas, comprimento 1110-1910 $\mu \mathrm{m}$, média $1483 \mu \mathrm{m}$ e desvio padrão 101; largura média 18,75-43,75 $\mu \mathrm{m}$; espessura da parede delgada com lume de 9,3-28,13 $\mu \mathrm{m}$; pontoações alternas, arredondadas, abundantes nas seções radial e tangencial, com diâmetro tangencial 4,35-7,56 $\mu \mathrm{m}$, média $6,13 \mu \mathrm{m}$ e desvio padrão 0,77. Parênquima axial invisível a olho nu e ind istinto sob lente (10x); apotraqueal difuso em agregados formando linhas; células do tipo seriado. Parênquima radial (raios) invisível sob lente (10x), unisseriados $(65,71 \%)$ e multisseriados $(34,29 \%)$, com mais de 2 séries; altura 3,25-11,93 mm, média 7,52 mm e desvio padrão 4,68; frequiência 6-20/mm, média 13,5/mm e desvio padrão 4,93; heterocelulares, com 8 fileiras (32,03\%) de células eretas no extremo superior, no centro 11 fileiras $(43,75 \%)$ de células procumbentes e 6 fileiras $(24,22 \%)$ de células eretas no extremo inferior; com 7-30 linhas de células; largura variando de 26,66-106,64 $\mu$ m [Tabela 3 (Anexo B) e Figura 28].

\subsubsection{Distribuição geográfica}

A distribuição desta espécie é muito ampla na Amazônia, entre as faixas

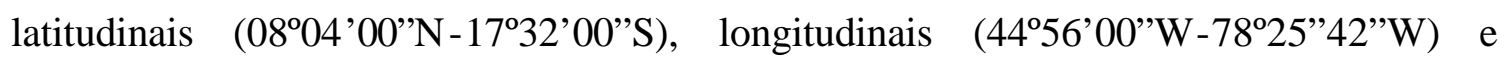
altitudinais $(7-1010 \mathrm{~m}$ ) [Tabela 6 (Anexo B)]. Esta liana pode ocupar várias zonas de vida na Bolívia, Brasil, Colômbia, Equador, Guiana, Guiana Francesa, Peru, Suriname e 
Venezuela. No Brasil nos Estados do Acre, Amazonas, Amapá, Maranhão, Mato Grosso, Pará, Rondônia, Roraima e Tocantins. No Acre nos municípios de Acrelândia, Assis Brasil, Brasiléia, Bujari, Capixaba, Cruzeiro do Sul, Epitaceolândia, Feijó, Jordão, Mâncio Lima, Manoel Urbano, Marechal Thamaturgo, Plácido Castro, Porto Acre, Porto Walter, Rio Branco, Rodrigues Alves, Santa Rosa do Purus, Sena Madureira, Senador Guiomard, Tarauacá e Xapuri (Figura 29). Espécie muito abundante em todas as localidades do Estado do Acre (caminhos, rodovias, trilhas, bordas de florestas primárias, florestas secundárias, beiras dos rios e principalmente nos igarapés) geralmente sobre solos pobres e secos a muito úmidos.

\subsubsection{Status ou situação populacional}

Esta espécie foi incluída na categoria LC (comuns e abundantes, fora de perigo) por ser abundante em todo o Estado do Acre e pela grande quantidade registros de coleta nos herbários. Encontra-se, porém, em áreas muito expostas e seu valor medicinal é desconhecido, sendo considerada espécie daninha e invasora das áreas de culturas agrícolas e pecuária, sendo eliminada pela raiz e/ou queimada para evitar sua rebrota [Tabela 7 (Anexo B)]. Devido a sua abundância e sua capacidade de regeneração, sua presença é possível em unidades de conservação. 


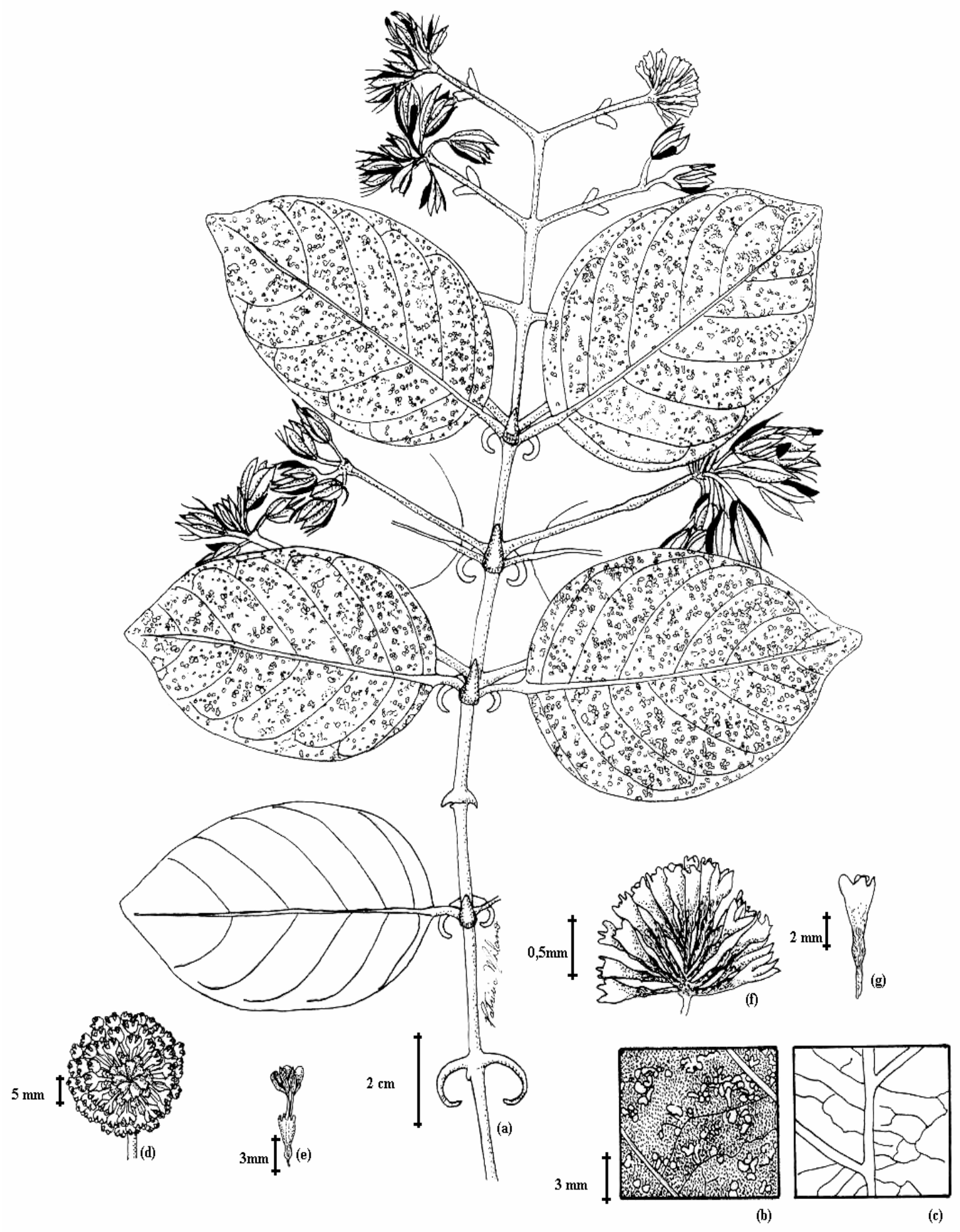

Figura 26 - Uncaria guianensis (Aubl.) J.F. Gmel. - ramo terminal com inflorecência e frutos (a), pubescência face abaxial folha nova e velha $(b, c)$, inflorescência capítulo (d), flor (e), inflorescência com flores fecundadas (f), cálice da flor (g) 


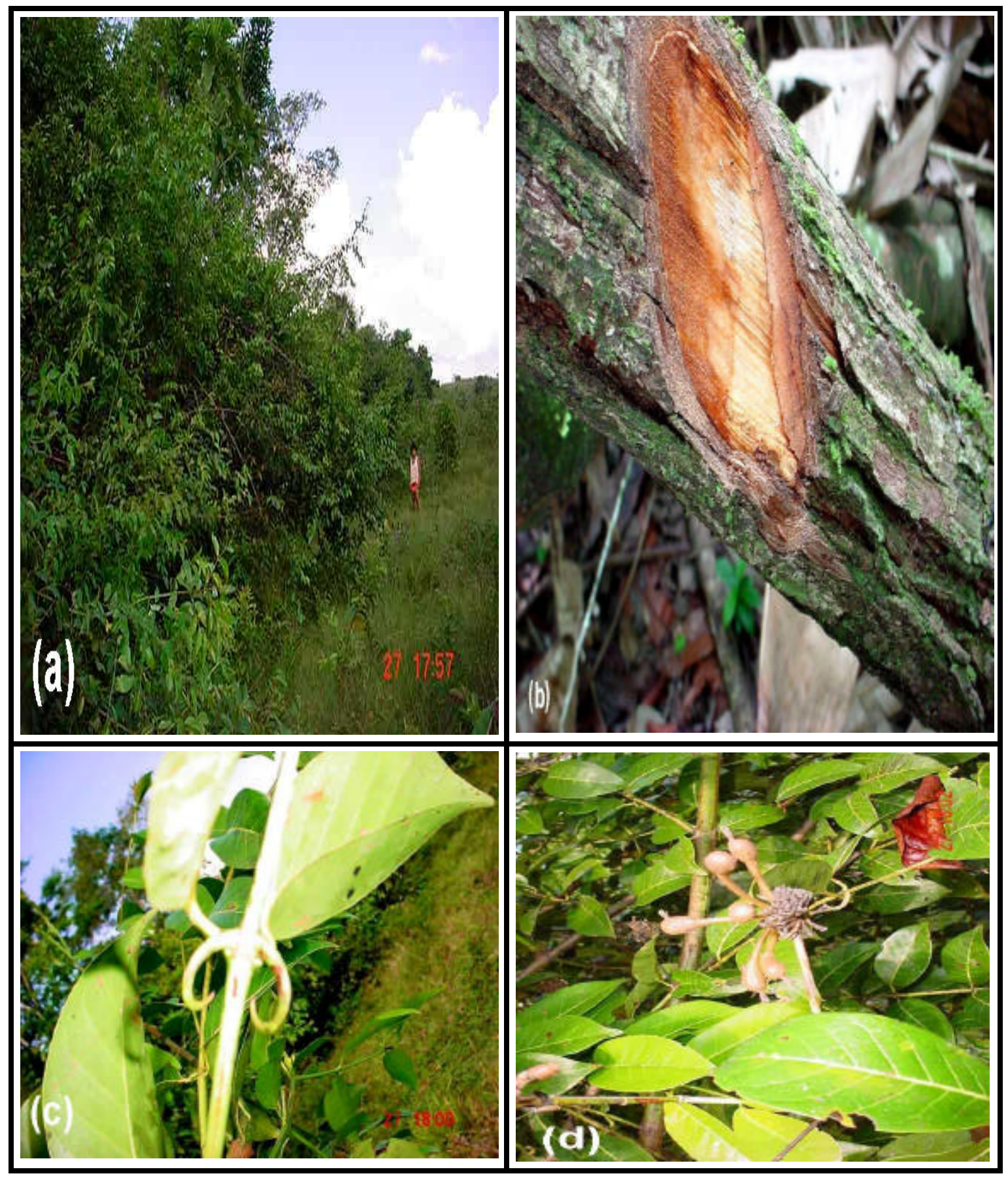

Figura 27 - Uncaria guianensis - (a) arbusto na borda da floresta, (b) casca externa e interna, (c) espinhos, (d) frutos imaturos 


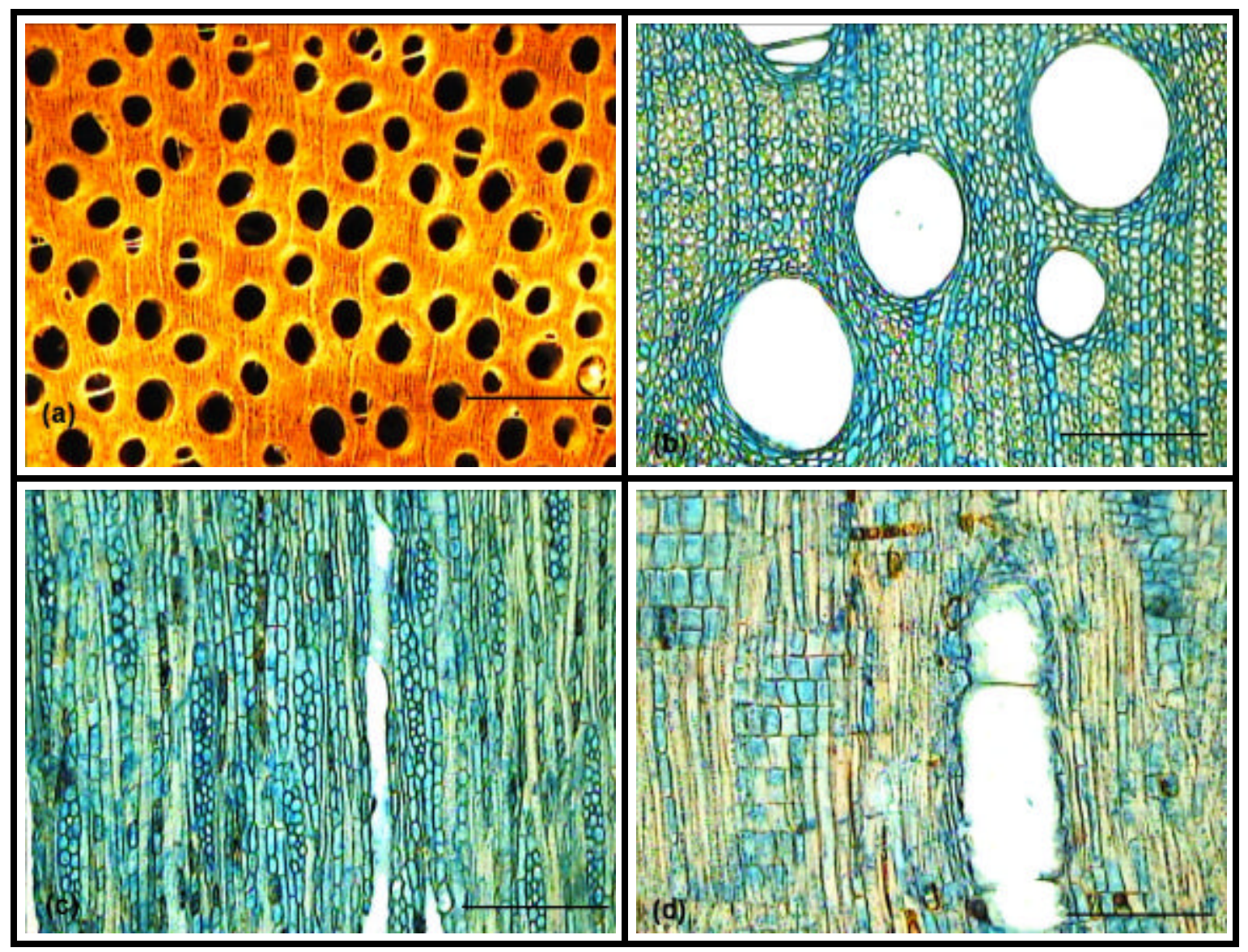

Figura 28 - Uncaria guianensis - (a) seção transversal (10x), (b) seção transversal (50x), (c) seção longitudinal tangencial (50x), (d) seção longitudinal radial do lenho (50x). Escala de barra "a" = $1 \mathrm{~mm}$, , b", "c" e "d" = $250 \mu \mathrm{m}$ 

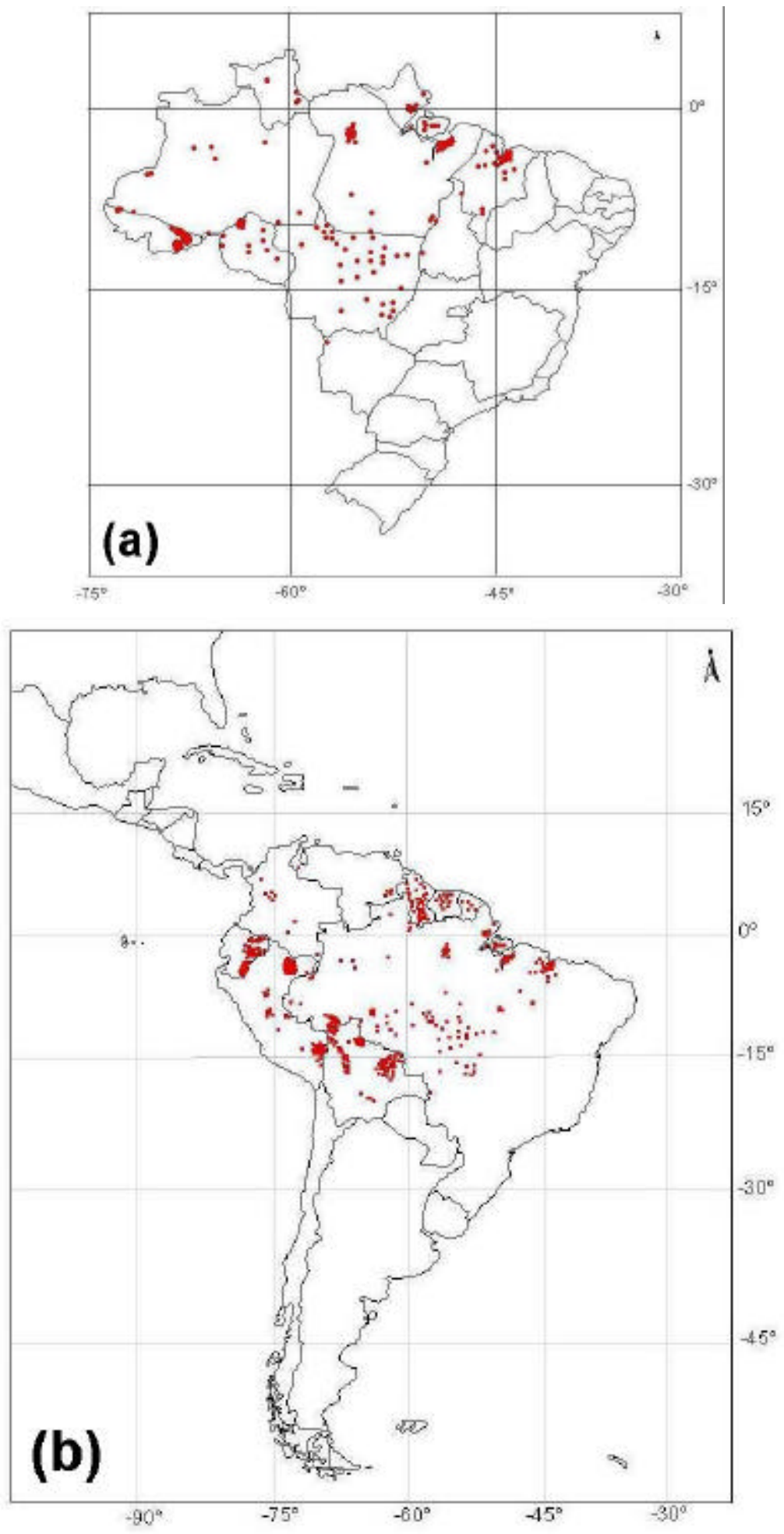

Figura 29 - Distribuição geográfica de Uncaria guianensis no Brasil (a) e na América Latina (b) 


\subsection{Uncaria tomentosa (Willd. ex Roem. \& Schult.) DC.}

Família botânica: Rubiaceae

Publicado em: Prodromus Systematis Naturalis Regni Vegetabilis 4: 349. 1830.\{Prodr.\}

Tipo: HT: Humboldt s.n., Colômbia: In ripa flumen Magdalenae prope Naers (B-W3910).

Sinônimo botânico: Nauclea aculeata Kunth \{Nov. Gen. Sp: 3: 382. 1819.\}; Nauclea aculeata Willd. \{Syst. Veg.: 5: 221. 1819\}; Nauclea tomentosa Willd. Ex Roem. \&

Schult. \{Syst. Veg.: 5: 221. 1819\}; Ourouparia tomentosa (Willd. ex Roem. \& Schult.) K. Schum. \{Fl. Bras.: 6(6): 132. 1889\}; Uncaria surinamensis Miq. \{Linnaea :19\}; Uncaria tomentosa var. dioica Bremek. \{Recueil Trav. Bot. Neerl 31: 263. 1934\}.

Nomes vulgares: Brasil: Acre: espera-aí, unha-de-gato; Amapá: jupinda, jupindá; Amazonas: espera-aí, unha-de-gato. Bolívia: bereoquida. Peru: garabato amarillo, jipotatsa, misho mentis, paotati mösha, samento, toroñ, tsachk, uña de gato, unganangui.

\subsubsection{Caracterização dendrológica}

Liana lenhosa, trepadeira ou às vezes arbusto rasteiro; pelo geral em florestas primárias ou exploradas ou em florestas secundárias antigas, raro em novas, requer luz solar moderada, pertencente ao grupo ecológico das heliófitas duráveis; pode alcançar até $35 \mathrm{~m}$ de comprimento e $12 \mathrm{~cm}$ de diâmetro, caule cilíndrico; casca externa marrom, ou marrom escuro, de aparência fissurada, fissuras longitudinais bem marcadas, ritidoma persistente; casca externa de cor ouro-avermelhada ou avermelhada, textura fibrosalaminar, ligeiramente pulverulenta quando seca. Com o corte do caule exsuda uma secreção aquosa de consistência fluída e de sabor adstringente. Ramos terminais de seção quadrada, cor verde-amarelado ou verde-pálido, folhinhas terminais em forma de lança, densamente pubescente. Folhas simples, opostas e dísticas, oblongas, oblongoovadas ou elíptico-abovadas, de 6,0-16 cm de comprimento e 4-10 cm de largura; margem inteira a ligeiramente sinuada; ápice agudo, raramente acuminado; base redonda ou cordada; consistência membranosa; nervura pinatinérvia oblíqua, nervuras secundárias de 7-10 pares; na parte adaxial cor verde-pálido ou verde-amarelado, com pouca ou nada de pubescente, na parte abaxial verde clara, com abundante tomentos, 
densamente nas nervuras. Pecíolo de 6-26 mm de comprimento e 1,0-2,0 mm de largura, ligeiramente pubescente. Estípulas interpeciolares, caducas ou persistentes, de forma deltóide, de 5-10 mm de comprimento e 3-8 $\mathrm{mm}$ de largura. Apresenta 1 par de espinhos, opostos, curvo-retos e pontiagudos, de consistência lenhosa, 8-10 mm de comprimento e 3-6 mm de largura. Inflorescências terminais ou axilares, composta em racimos ou cimas de capítulos globosos, de 6-20 cm de comprimento; cada capítulo de 1,3-3,0 cm de diâmetro; pedúnculo de 1,2-3,0 $\mathrm{mm}$ de comprimento e 1-2,0 $\mathrm{mm}$ de largura, tomentoso. Flores bissexuais e actinomorfas, com hipanto tubular, sésseis. Cálice gamossépalo, tubular, de 0,8-1,3 mm de comprimento e 0,7-1,1 mm de diâmetro; com 5 lóbulos em forma de dentes pontiagudos, com pêlos vilosos, longos nas margens e mais longos na base. Corola gamopétala, com 5 lóbulos redondos, de 6-12 mm de comprimento e 2,5-6 mm de largura, de cor amarelado, densamente pubescente na parte exterior, parte interior glabra. Androceu com 5 estames adnatos a garganta da corola, alternipétalas, com filetes curtos; anteras oblongas, dorsifixas, com base prolongada e divergentes, de 0,8-1,0 $\mathrm{mm}$ de comprimento e 0,3-0,4 $\mathrm{mm}$ de largura. Gineceu com 1 pistilo de estigma elipsóide de 0,4-0,6 mm de comprimento, estilo linear, excerto, até 4 mm de comprimento; ovário ínfero, 2-carpelar, 2-locular, sincárpico e placentação axilar. Fruto seco, deiscente, tipo cápsula elipsóide, de 4-8 mm de comprimento e 2,5-7 mm de largura; deiscência longitudinal septicida, com cálice persistente e acrescente, com numerosas sementes. Sementes fusiformes com asas membranosas, um extremo linear e o outro bi-linear, de 2,0-3,0 $\mathrm{mm}$ de comprimento e 0,4-0,6 mm de largura (Figuras 30 e 31).

\subsubsection{Caracterização anatômica do lenho}

Cerne indistinto do alburno, de cor avermelhada, vermelho-amarelada, laranjaamarelada, a rosa-avermelhada, brilho moderado, odor imperceptível, levemente amargo, densidade de massa baixa, resistência ao corte macia, grã direita, textura média/grossa. Camadas de crescimento pouco distintas, demarcadas pela espessura da parede celular das fibras. Vasos visíveis a olho nu; difusos; arranjo radial; solitários $(96,15 \%)$ e múltiplos $(3,85 \%)$ de $2-3$ células, frequiência $3-8 / \mathrm{mm}^{2}$; diâmetro tangencial 
do lume 119,97-613,18 $\mu \mathrm{m}$, média 334,08 $\mu \mathrm{m}$ e desvio padrão 110,62, forma arredondada; comprimento 239,94-866,45 $\mu \mathrm{m}$, média 509,21 $\mu \mathrm{m}$ e desvio padrão 107,48; apêndice curto, menor a 1/3 do comprimento do vaso e em ambas extremidades; placas de perfuração simples; depósitos distintos; pontoações intervasculares areoladas, alternas, arredondadas, abundantes, ornamentação ausente, diâmetro tangencial 3,69$8,05 \mu \mathrm{m}$, média $6,30 \mu \mathrm{m}$ e desvio padrão 0,98; pontoações raio-vasculares aeroladas, alternas, arredondadas, abundantes, diâmetro tangencial 4,25-7,25 $\mu \mathrm{m}$, média de 5,94 $\mu \mathrm{m}$ e desvio padrão de 0,91 ; pontoações parênquimo-vasculares semelhantes às intervasculares. Fibras com pontoações distintamente areoladas maior de $3 \mu \mathrm{m}$; curtas a longas, comprimento 509-1760 $\mu \mathrm{m}$, média $980 \mu \mathrm{m}$ e desvio padrão 110; largura média 18,75-46,88 $\mu \mathrm{m}$; espessura da parede delgada a espessa, com lume de 15,63-25,00 $\mu \mathrm{m}$; pontoações alternas, arredondadas, muito abundantes nas seções radial e tangencial, com diâmetro tangencial 4,19-7,87 $\mu \mathrm{m}$, média 6,07 $\mu \mathrm{m}$ e desvio padrão 0,58. Parênquima axial invisível a olho nu e indistinto sob lente (10x); apotraqueal difuso em agregados formando linhas; células do tipo seriado. Parênquima radial (raios) invisível sob lente (10x), unisseriado $(63,11 \%)$ e multisseriado $(36,84 \%)$, com mais de 2 séries; altura 3,25$11,93 \mathrm{~mm}$, média $6,69 \mathrm{~mm}$ e desvio padrão 3,25; freqüência 3-16/mm, média 8,9/mm e desvio padrão 4,65; heterocelulares, com 5 fileiras $(20,16 \%)$ de células eretas na extremidade superior, no centro 11 fileiras $(45,16 \%)$ de células procumbentes e 9 fileiras (34,68\%) de células eretas na extremidade inferior; com 7-42 linhas de células; largura variando de 20-106,64 $\mu \mathrm{m}$ [Tabela 3 (Anexo B) e Figura 32].

\subsubsection{Distribuição geográfica}

A distribuição desta espécie é muito ampla na Amazônia e na América Central, podendo ser encontrada nas faixas latitudinais (15\%30'00” $\left.\mathrm{N}-13^{\circ} 36^{\circ} 00^{\prime} \mathrm{S}\right)$, longitudinais (51 58'00” W-8900”00”W) e altitudinais (5-750 m) [Tabela 6 (Anexo B)]. Esta espécie tem uma distribuição quase afim a da Uncaria guianensis encontrando-se, porém, principalmente sobre solos férteis. Na Amazônia e na América Central ocupam várias zonas de vida. Pode se encontrada em Bolívia, Brasil, Colômbia, Costa Rica, Equador, Guatemala, Guiana, Guiana Francesa, Nicarágua, Panamá, Peru e Venezuela. No Brasil 
ocorre nos Estados do Acre, Amapá, Amazonas e Pará. No Acre nos municípios de Cruzeiro do Sul, Feijó, Manoel Urbano e Porto Walter (Figura 33). Espécie muito abundante nos igarapés e nas clareiras das florestas primárias; nos caminhos e trilhas fechadas, em geral sobre solos ricos em nutrientes e muito úmidos.

\subsubsection{Status ou situação populacional}

Esta espécie foi incluída na categoria VU (perigo a médio prazo). Muito abundante nas áreas de amostragem, embora muito expostas a exploração. Os colonos e os nativos coletam a sua casca e raiz pelo alto valor comercial, sendo vendida aos comerciantes do Estado do Amazonas e no Peru. O tipo de extração aplicado não permite o sua rebrota, matando a planta [Tabela 7 (Anexo B)]. Devido a sua relativa abundância e sua capacidade de regeneração, sua presença é possível em unidade de conservação. 


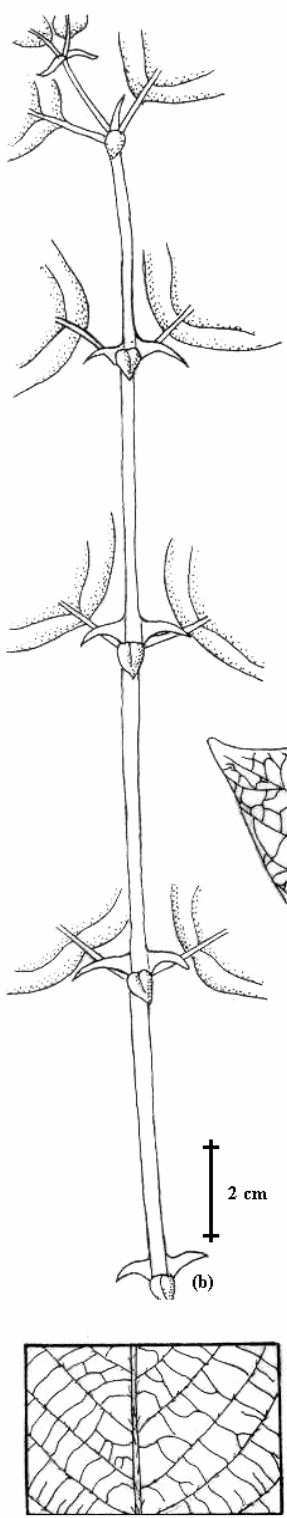

(h)
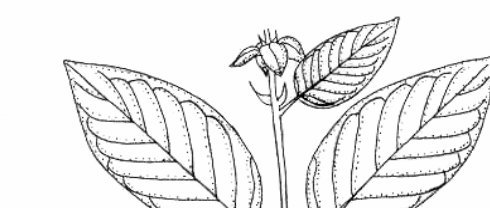

a
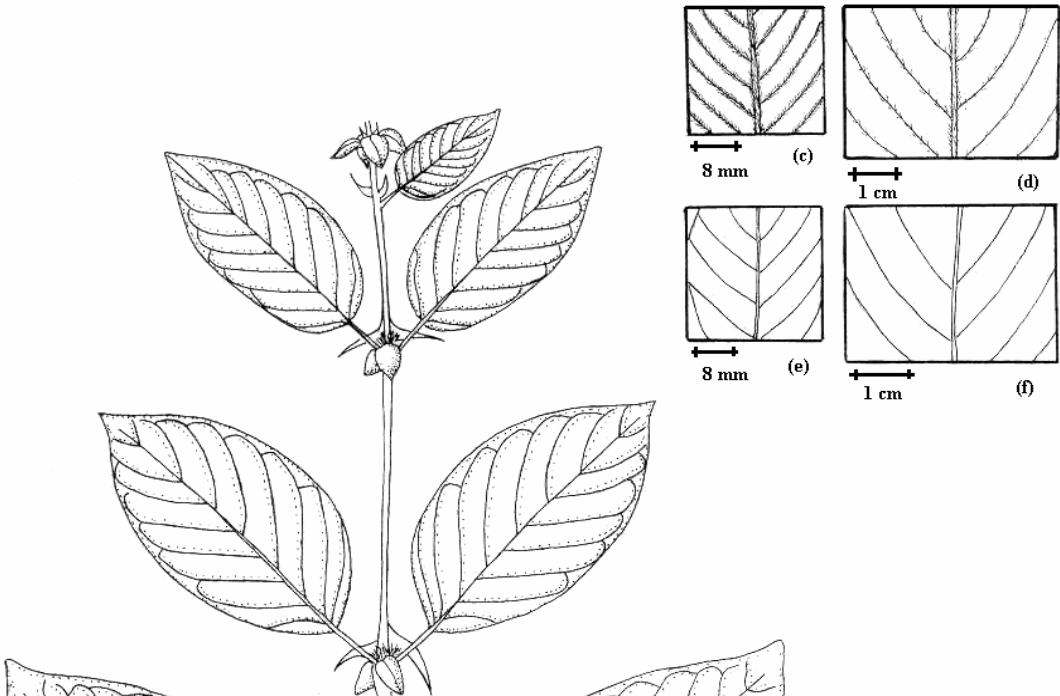

$8 \mathrm{~mm} \quad$ (e)
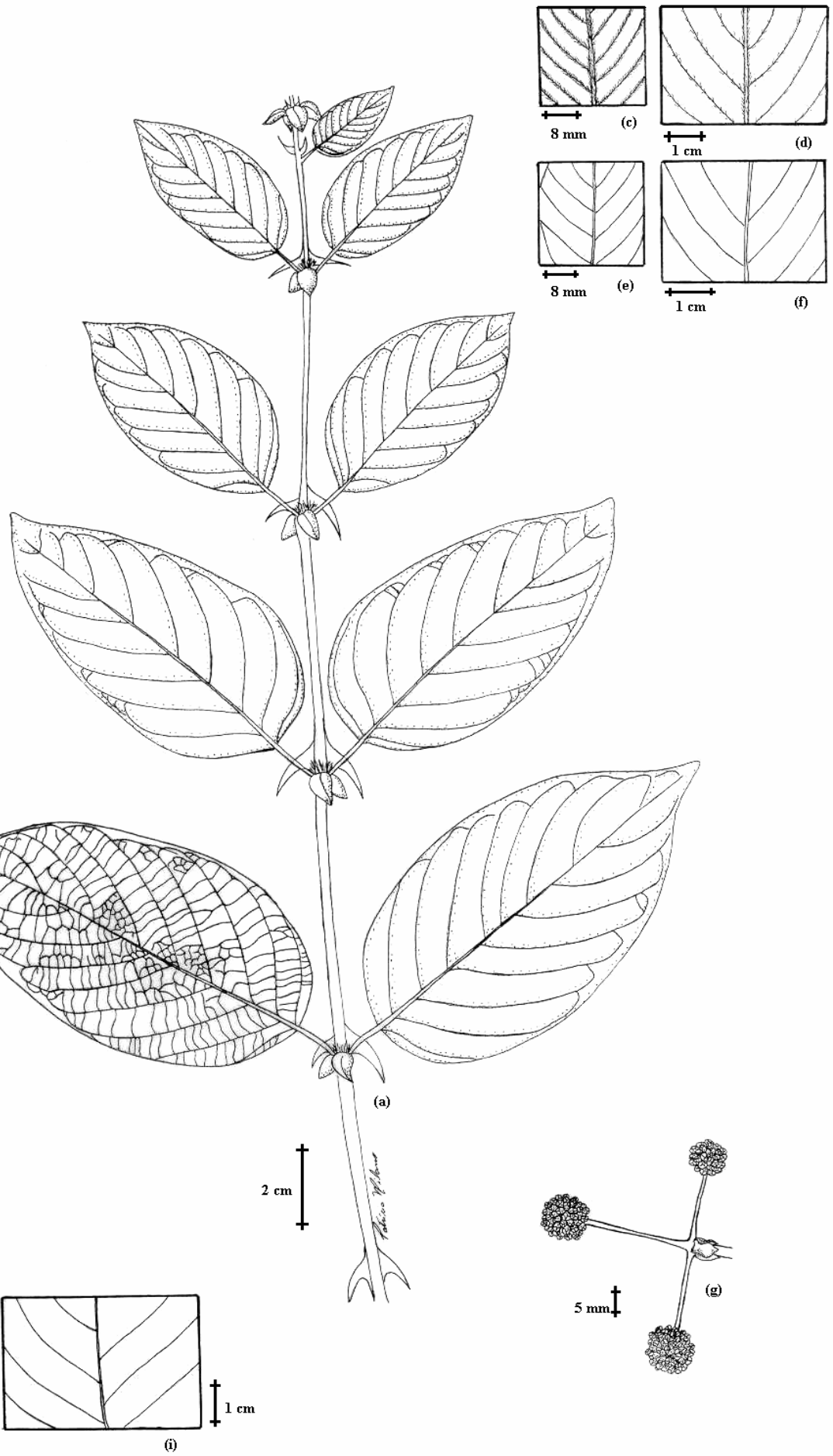

Figura 30 - Uncaria tomentosa (Willd. ex Roem. \& Schult.) DC. - ramo terminal (a), detalhe espinhos no caule (b), pubescência face abaxial folha nova e velha (c,d), pubescência na face adaxial folha nova e velha (e,f), inflorescência imatura $(\mathrm{g})$, detalhe de nervura da folha com pubescência face abaxial e adaxial $(\mathrm{h}, \mathrm{i})$ 

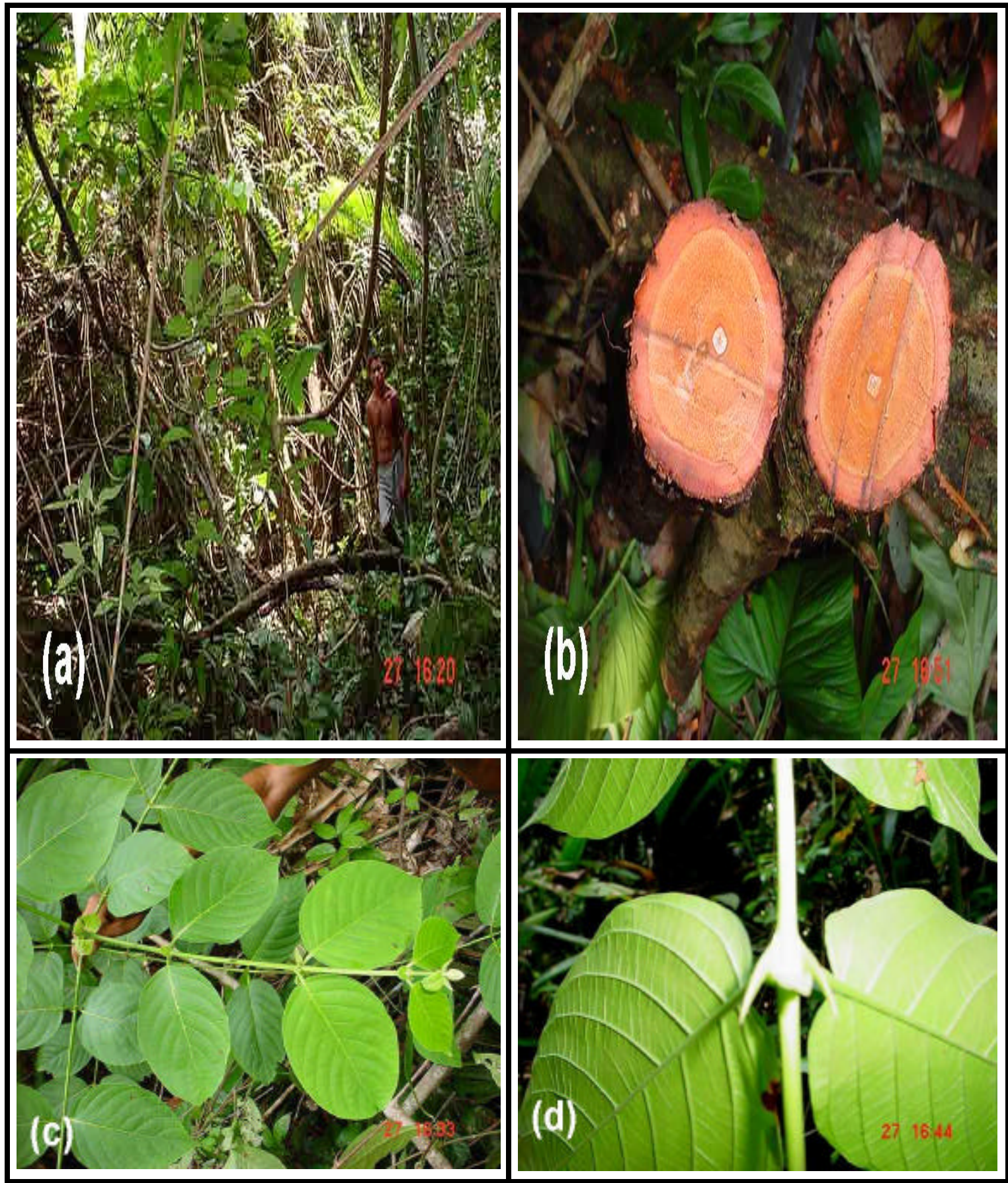

Figura 31 - Uncaria tomentosa - (a) liana no interior do sub-bosque, (b) casca interna e lenho verde, (c) ramo terminal, (d) espinhos 


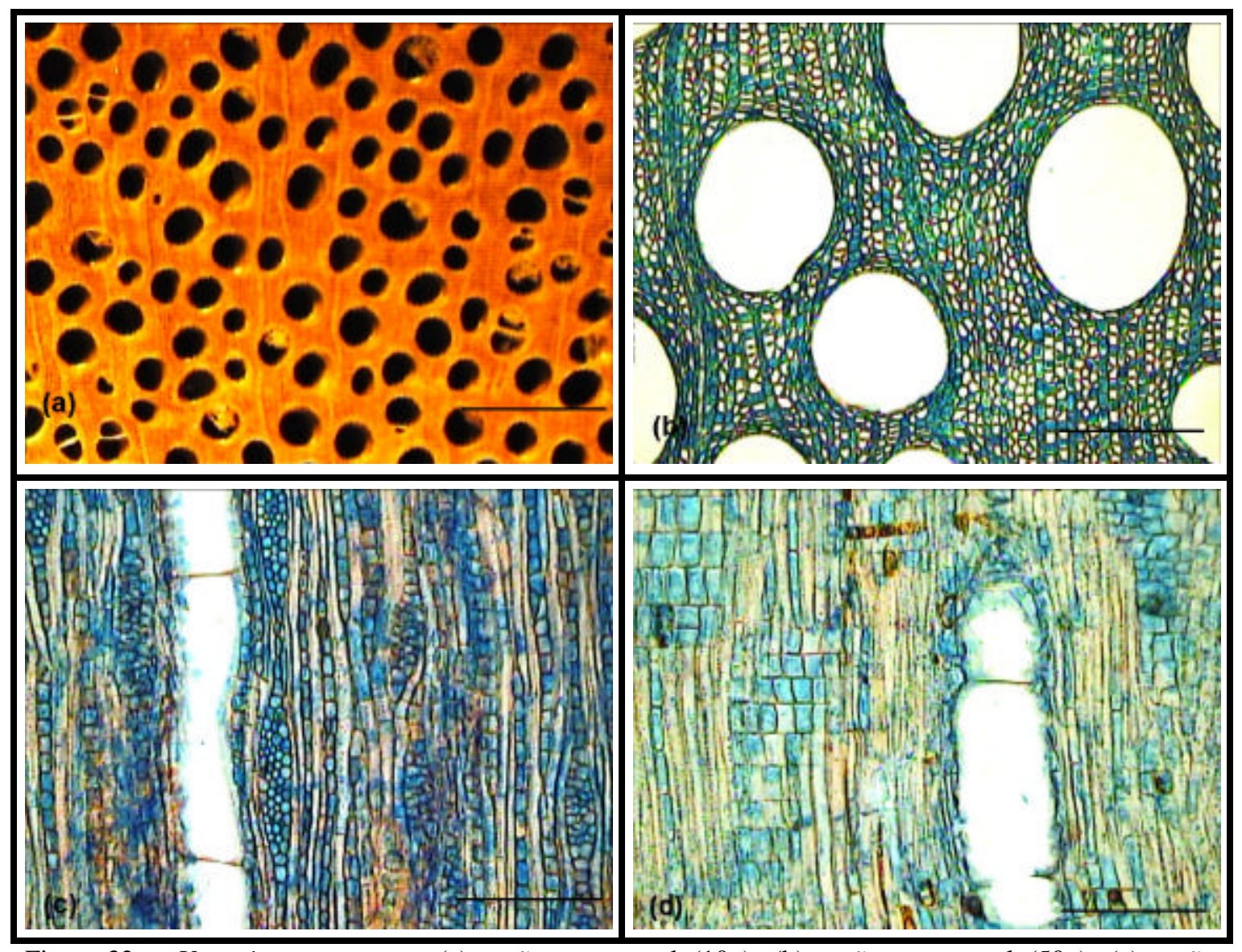

Figura 32 - Uncaria tomentosa - (a) seção transversal (10x), (b) seção transversal (50x), (c) seção logitudinal tangencial (50x), (d) seção longitudinal radial do lenho (50x). Escala de barra "a" = $1 \mathrm{~mm}$, "b", "c" e "d" = $250 \mu \mathrm{m}$ 

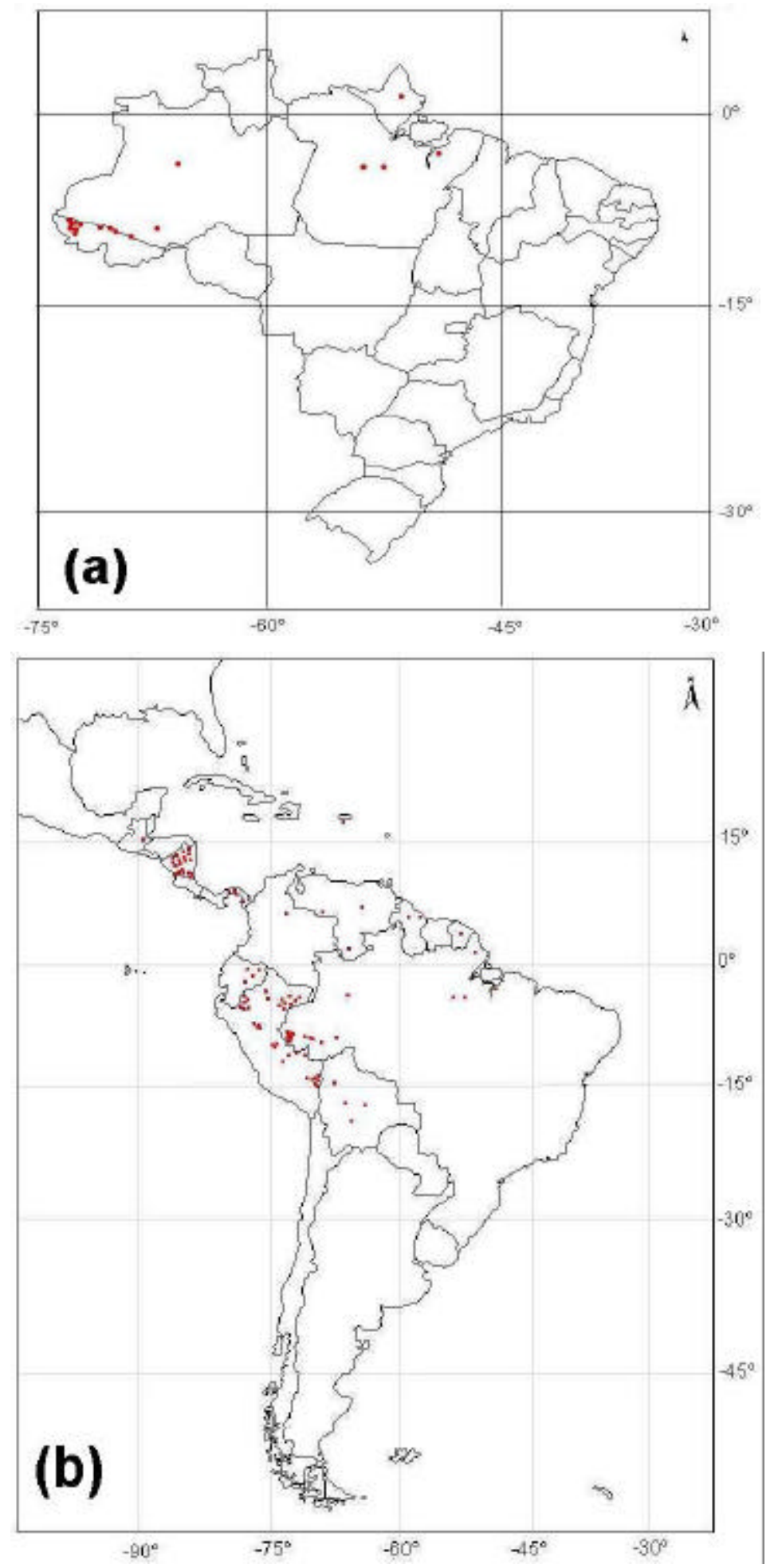

Figura 33 - Distribuição geográfica de Uncaria tomentosa no Brasil (a) e na América Latina (b) 


\section{DISCUSSÃO}

O exame das exsicatas nos herbários, a consulta bibliográfica e a pesquisa nos "sites" especializados da Internet proporcionaram informações científicas imprescindíveis para a identificação das espécies dos 3 gêneros avaliados, a partir dos materiais botânicos coletados. Ressalta-se que a maioria das espécies não conta com dados atualizados, exceto para os aspectos da sua farmacologia e aplicações medicinais; muitas das descrições referentes a botânica, dendrologia e anatomia do lenho disponíveis na literatura são incompletas. As coletas botânicas realizadas no Estado do Acre, no presente trabalho, constituem-se em aporte significativo para os Herbários das instituições apoiadoras - HPZ, ESA, SP, MG - por serem espécies registradas há muitos anos na região norte do país, possibilitando conhecer a sua distribuição geográfica e monitorar o seu status de conservação.

A determinação sistemática das espécies ao nível de família foi facilitada pelas suas características conspícuas, pelo baixo relacionamento genético existente entre as mesmas, expresso pela disposição das folhas, estípulas, glândulas, inflorescência flores, fruto e anatomia do lenho (Cronquist, 1988; Bremer et al., 1998 e APG, 2003). Enquanto que na família Euphorbiaceae as plantas apresentam folhas alternas com 1 par de glândulas geralmente na base do limbo, flores unissexuais em fascículo ao longo de racimos e frutos tricocos, na família Rubiaceae as folhas são opostas, com 1 par de estípulas inter-pecíolos, flores bissexuais em cimas, panículas ou agregadas em capítulos e frutos bi-capsulares (Allem, 1978; Delprete \& Cortez, 2002; Steyermark, 1974; Rea, 1995 e Gentry, 1993). Com respeito às características gerais do lenho, os representantes da família Euphorbiaceae apresentam, de modo geral, cerne caracterizado pela cor mais clara, sabor e odor indistintos, grã direita, textura fina a grosseira, pouco lustrosa e de densidade baixa; os da família Rubiaceae têm, de modo geral, lenho caracterizado pela cor escura, sabor amargo, odor 
indistinto, grã direita, textura fina a média, levemente lustrosa e pesada a moderadamente pesada (Arens \& Lechthaler, 1958; Mainieri, 1958, 1962 \& 1965; Loureiro, 1968; Brasil, 1967; Rogel-Gomez, 1982; Cardoso, 1986; Florshem \& Rocha, 1987; Fedalto et al., 1989). No entanto, para cada uma das famílias enumeradas a diferenciação das espécies é complexa dentro de cada gênero estudado.

A descrição completa e detalhada das 8 espécies dos 3 gêneros, apresentada no trabalho, incluindo os parâmetros morfológicos de fácil observação no campo (hábito de crescimento, fuste, ramificação, casca, condições ecológicas) e ilustrações (detalhes das folhas e flores) permitirá a elaboração de um "Guia de Campo para a Identificação das Espécies”.

\subsection{0 gênero Croton}

\subsubsection{Identificação das espécies e dendrologia}

O gênero caracteriza-se pelo significativo número de espécies e pela sua complexidade taxonômica (Lima \& Pirani, 2003), o que levou Webster (1993) a compilar uma revisão minuciosa dos parâmetros morfológicos das flores e folhas para a identificação das espécies, contando com o necessário apoio de especialistas do taxon. De todas as espécies de Croton existentes nos herbários, somente parte pode ser coletada nos trabalhos de campos, em função das dificuldades nos deslocamentos, das características próprias das regiões úmidas tropicais, dos custos financeiros e pelo desmatamento para o uso da madeira e ampliação da fronteira agropecuária. Dentre estas, citam-se o Croton gossypiifolius Vahl (MG 42957) reportada em Cruzeiro do Sul; C. miquelensis A.M.Fergunson (INPA 161612 e INPA 24145) em Cruzeiro do Sul e Tararaucá. Duas espécies não reportadas no Acre, mas amplamente abundantes e bem distribuídas na Amazônia, são $C$. cuneatus Klotzsch e C. draconoides Müell.Arg., esta considerada afim a C. urucurana Baill. (MG14388) reportada em Rio Branco há 90 anos e, recentemente, por Secco (2002). Croton trinistatis Millsp. foi observada no Estado todo, mas não foi considerada por ser de porte herbáceo. Deve-se mencionar, também, a grande variação morfológica das plantas (ex: folhasquanto a forma, disposição, consistência, coloração e tamanho; pêlos, glândulas) em 
uma mesma espécie de Croton (ex: Croton lechleri, C. matourensis, C. palanostigma e C. billbergianus), face as diferenças na idade das plantas, a ampla distribuição geográfica e ao processo de adaptação, resultando em dificuldades para a identificação das espécies.

O material botânico de Croton billbergianus coletado no Acre foi identificado inicialmente como C. calycularis Huber (descrito em 1914, Bulletin de la Societe Botanique de Geneve), com base nas exsicatas, nas descrições da literatura e na análise de especialistas no taxon. Posteriormente, pela revisão das exsicatas da América Central existentes no Herbário do Museu Goeldi verificaram-se similaridades com C. billbergianus Müll. Arg. (descrito em 1865, Linnaea) que, por antigüidade, deve ser reconhecido em relação a $C$. calycularis, que passa ser considerada com sinonímia botânica. Para um diagnóstico conclusivo há necessidade, no entanto, de novas coletas botânicas e estudos complementares sobre a anatomia do lenho, química, palinologia, etc., dessas espécies.

\subsubsection{Estrutura anatômica do lenho}

A estrutura anatômica do lenho, constituiu-se em importante parâmetro morfológico das árvores do gênero Croton, utilizado na identificação das espécies. Nesse aspecto as informações disponíveis na literatura especializada restringem-se a um pequeno número de publicações científicas, além das dificuldades inerentes ao grande número de espécies, conforme mencionado.

O lenho de cor branca (em diversas tonalidades de amarela, cinza a bege), para as espécies do gênero Croton é coincidente com a descrição de vários autores (Dètienne \& Jacquet, 1983; Alcir et al., 1999; Loureiro, 1968; Mainieri \& Chimelo, 1989) e pode ser confundido com outros gêneros da família Euphorbiaceae, a exceção de Gymnanthes e Hieronima (lenho amarelo-oliveiro-acastanhado a vermelhoachocolatado) (Rogel-Gomez, 1982 e Arens \& Lechthaler, 1958). O gosto e odor do lenho são indistintos na família e no gênero, a de Celaenodendrum mexicanum (lenho amargo e de odor desagradável) (Barajas-Morales, \& Echenique-Manrique, 1976). A grã direita e a textura média do lenho são semelhante às descritas por outros autores, 
embora com diferenças relacionadas ao brilho do lenho (Dètienne \& Jacquet, 1983; Loureiro, 1968 e Mainieri \& Chimelo, 1989). A densidade do lenho varia de baixa (Croton matourensis e C. lechleri) a média (demais espécies), em função da idade das plantas e do tipo de solos onde ocorrem. As estruturas estratificadas são indistintas e as camadas de crescimento distintas ou levemente distintas, são coincidentes com inúmeros autores (Freitas et al., 1992; Dètienne \& Jacquet, 1983; Alcir et al., 1999; Loureiro, 1968; Mainieri \& Chimelo, 1989) embora não se distinguindo no gênero Hura (Arens \& Lechthaler, 1958; Mainieri, 1962; Brasil, 1967; Mainieri, 1965). Os elementos de vaso no lenho das espécies de Croton são geralmente distintos a exceção de $C$. billbergianus e corroboram a descrições de outros autores (Mainieri, 1958; Loureiro, 1968; Dètienne \& Jacquet, 1983; Mainieri \& Chimelo, 1989; Alcir et al., 1999; Alves \& Angylossy-Alfonso, 2000). As demais características dos vasos (distribuição, forma, agrupamento, frequiência, comprimento, apêndices, tiloses) são também, comuns às apresentadas na literatura por diversos autores (Mainieri \& Chimelo, 1989; Dètienne \& Jacquet, 1983; Alcir et al., 1999 e Loureiro, 1968). Diferenças entre espécies de Croton foram observadas quanto ao agrupamento (grupos de 2-4, raro 5, em C. billbergianus); frequiência (3-8/ $\mathrm{mm}^{2}$ em C. matourensis e 16-26/mm² em C. billbergianus); diâmetro tangencial (20-106,64 $\mu \mathrm{m}$ em $C$. floribundus e 66,65-239,94 $\mu \mathrm{m}$ em C. matourensis e C. lechleri), comprimento (159,96-1053,07 $\mu \mathrm{m}$ em C. matourensis), arranjo radial (exceto em C. palanostigma, radial e diagonal) e obstrução por tilos ou óleo resina (C. floribundus e $C$. palanostigma). Da mesma forma, parênquima longitudinal no lenho das espécies de Croton (apotraqueal difuso em agregados tendendo a formar linhas e/ou paratraqueal aliforme linear confluente com apotraqueal difuso) muito evidente em $C$. matourensis e C. palanostigma, é coincidente com o descrito por outros autores (Freitas et al., 1992; Dètienne \& Jacquet, 1983; Alcir et al., 1999; Loureiro, 1968 e Mainieri \& Chimelo, 1989).

As características do parênquima radial são, da mesma forma, coincidentes com a literatura (Dètienne \& Jacquet, 1983; Rogel-Gómez, 1982; Alcir et al., 1999; Loureiro, 1968; Mainieri \& Chimelo, 1989; Mainieri, 1958, 1962, 1978; Florsheeim 
\& Rocha, 1987; Fedalto et al., 1989 e Barajas-Morales \& Echenique-Manrique, 1976). Diferenças foram observadas entre as espécies, com respeito ao número de células (4 em C. palanostigma até 32 linhas de células em C. billbergianus), altura (1,73-3,91 mm em C. lechleri a 3,90-10,85 mm em C. matourensis), freqüência (79/mm em C. lechleri a > 10/mm em C. billbergianus) e pontoações (poligonais e arredondadas em C.floribundus).

As fibras com comprimento variável (760-1300 $\mu \mathrm{m}$ em $C$. palanostigma e $C$. billbergianus a 950-1410 $\mu \mathrm{m}$ em $C$. floribundus), largura (18,75-43,75 $\mu \mathrm{m}$ em todas as espécies), espessura da parede (delgadas; exceto muito delgadas em $C$. matourensis) e pontoações areoladas arredondadas $(0,56-5,64 \mu \mathrm{m})$.

\subsubsection{Distribuição geográfica}

As informações sobre a distribuição geográfica das espécies do gênero Croton na literatura especializada são escassas (Webster, 1993). A compilação e a atualização da distribuição das espécies de Croton foram possíveis somente com as consultas das exsicatas dos herbários, dos "sites" do Missouri e New York Botanical Garden e pelos resultados dos levantamentos de campo.

Com respeito à distribuição geográfica, verifica-se que Croton billbergianus e C. palanostigma têm distribuição mais ampla na Amazônia atingindo até a América Central (Burger, 1993), sendo que C. matourensis foi identificada em área restrita no Panamá. Enquanto a $C$. billbergianus, apesar de sua ampla distribuição o número de exsicatas no Brasil são reduzidos ao contrário do que se verificou nos herbários do exterior. Croton lechleri, típica nas florestas úmidas tropicais da Amazônia, pode ser encontrada em locais semelhantes nas vertentes do Oceano Pacifico (Buitrón, 2000; Forero et al., 2000 e Meza \& Ayala, 1998) e C. floribundus tem sua distribuição concentrada na Mata Atlântica e no Cerrado das regiões sul-sudeste do Brasil (Smith \& Downs, 1959). Os levantamentos de campo indicaram o primeiro registro de $C$. floribundus na região norte, em área de desmatamento intensivo utilizada para pastagem no município de Mâncio Lima-Acre. Ressalte-se que as condições

ambientais -luminosidade, efeito antrópico, etc.- que proporcionaram o 
desenvolvimento dessa vegetação nessa região do Estado do Acre são, de certa forma, próximas as de ocorrência de Croton floribundus na região sul-sudeste do país.

As espécies de Croton encontram-se em ambos hemisférios, com $C$. billbergianus e $C$. matourensis mostrando maior amplitude latitudinal e $C$. palanostigma sendo a de menor amplitude (Bastien, 1991). Croton floribundus possui a maior amplitude longitudinal, com uma significativa área localizada entre as regiões sul-sudeste, seguida de Croton palanostigma e de C. lechleri e C. billbergianus que são as de menor amplitude. A distribuição altitudinal de C. lechleri $(2.100 \mathrm{~m})$ corresponde as localidades na Cordilheira dos Andes no Peru e no Equador; seguida de $C$. floribundus $(1.700 \mathrm{~m})$ na Serra de Caeté-MG no Brasil, de C. billbergianus (10$1.000 \mathrm{~m}$ ) na América Central e $C$. matourensis e $C$. palanostigma $(1.000 \mathrm{~m})$ na Amazônia (Macbride, 1936; Bastien, 1991; Brako \& Zurucchi, 1993 e Webster, 1993) Com referência aos aspectos ecológicos verifica-se que Croton billbergianus, C. floribundus e C. palanostigma, são observadas com freqüência nas bordas dos caminhos, das trilhas e das florestas secundárias, chácaras ou áreas de pastagem abandonados, em solos argilosos; enquanto que $C$. lechleri, mais exigente, ocorre em solos férteis e úmidos das margens dos rios (Meza \& Ayala, 1998 e Forero, 2000); $C$. matourensis tem preferência para as florestas secundárias antigas ou nas clareiras e bordas das florestas primárias (Vallilo, 1998 e Santini et al, 1999).

\subsection{4 "Status" de conservação ou situação populacional}

A inclusão das plantas de Croton lechleri e C. palanostigma na categoria CR (perigo crítico) indica o elevado risco de sua extinção em estado silvestre. A sua distribuição particular e localização pontual e o fato das coletas botânicas terem datas recentes, caracterizam essas espécies como muito raras no Acre, embora sejam abundantes em outras áreas da Amazônia (Forero et al., 2000).

Ao contrário, as plantas de Croton billbergianus, C. matourensis, incluídas na categoria LC (preocupação menor), são comuns e abundantes em estado silvestre e nos registros dos herbários sendo, desta forma, consideradas fora de risco de extinção. 
Por outro lado, as plantas de C. matourensis são mantidas pelos colonos e pelos nativos para a futura utilização de sua madeira (Burger, 1993 e Santini et al., 1999).

A inclusão das plantas de Croton floribundus na categoria DD (dados insuficientes), deve-se a sua $1^{\text {a }}$ coleta registrada no Estado do Acre não proporcionando, portanto, informações suficientes para diagnosticar o seu nível de risco. Apesar de comum e abundante nas regiões sul e sudeste, constitui-se em espécie de rara ocorrência na Amazônia, comprovada pela ausência de registros nas coletas das expedições já realizadas no passado e por não ter sido encontrada nas áreas de estudo.

As espécies de Croton são, de modo geral, consideradas pelos agricultores como invasoras ou daninhas por ocorrerem em florestas secundárias e nos limites de cercas ou bordas e caminhos das propriedades rurais sendo, desta forma, eliminadas face a sua competição com as culturas agrícolas regionais, como a banana, mandioca, etc. ou com as pastagens. Por outro, as árvores adultas de $C$. lechleri e $C$. palanostigma têm, frequientemente, a sua casca retirada para a obtenção do látex com aplicação medicinal, induzindo a morte das plantas (Jong et al., 1999; Meza, 1999b e Forero et al., 2000).

\subsection{Os gêneros Cinchona e Uncaria}

\subsubsection{Identificação das espécies e dendrologia}

No gênero Cinchona existe grande dificuldade na identificação das espécies, a exemplo de outras desta família, como Landerbergia, Remijia e Macrocnerum (Andersson \& Persson, 1991). A revisão desse gênero feita por Andersson (1998) (estabelecendo os sinônimos, excluindo e incorporando espécies, criando o gênero Cinchonopsis então pertencente a Cinchona) permite, de certa forma, a diferenciação de suas espécies. As plantas de Cinchona delessertiana Standl. e Cinchona humboldtiana Roem. \& Schult foram relatadas na Amazônia Brasileira (Acervo MG) e na Peruana (Zevallos, 1989) sendo plausível a sua ocorrência, sobretudo na Cordilheira da Serra Divisor, acima de $600 \mathrm{~m}$ de altitude. As plantas de C. amazonica apresentam grande dificuldade para a sua identificação pelas variações morfológicas 
resultantes da sua adaptação às condições de sua ampla área de distribuição geográfica.

As duas espécies do gênero Uncaria mostraram diferenças no hábito de crescimento, nas condições ecológicas e na morfologia dos órgãos reprodutivos e vegetativos (Obregón, 1995; Domínguez-Torrejón, 1997 e Zevallos et al., 2000).

\subsubsection{Estrutura anatômica do lenho}

As características do lenho das espécies de Cinchona e Uncaria são coincidentes com as descritas por diversos autores (Freitas et al., 1992; Dètienne \& Jacquet, 1983; Alcir et al., 1999; Loureiro, 1968; Mainieri \& Chimelo, 1989; Zevallos et al., 2000 e Zevallos et al., 2002). A cor do lenho é variável (amarelado quando recém-cortado e rosado-avermelhado após sua oxidação em Cinchona amazonica; avermelhado, com variações do amarelado ao rosado ou bege ao alaranjado em Uncaria) e característica da família Rubiaceae exceto em Pentagonia e Chomelia (branco ao bege claro) (Freitas, 1922; Acosta, 1960; Dètienne \& Jacquet, 1983).

Outras características de destaque nas 3 espécies são o gosto (levemente amargo), o odor (indistinto), a grã (direita), textura (média em $C$. amazonica) e média-grossa em Uncaria); o brilho (moderado); a densidade de massa (baixa média em Uncaria a média em Cinchona) (Dètienne \& Jacquet, 1983; Zevallos, 1989; Zevallos et al., 2001 e Acosta, 1960).

Os elementos de vaso são característicos, com algumas diferenças entre espécies, como o diâmetro (variável, principalmente em C. amazonica); distribuição (predominantemente solitários em Uncaria e grupos de >2 em C. amazonica);

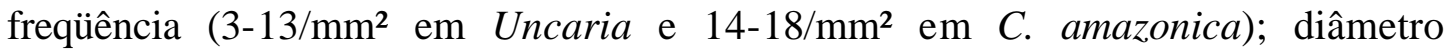
tangencial (66,65-119,97 $\mu \mathrm{m}$ em C. amazonica a $>100 \mu \mathrm{m}$ em Uncaria); comprimento (666,50-1599,60 $\mu \mathrm{m}$ em C. amazonica a 239,94-866,45 $\mu \mathrm{m}$ em Uncaria) (Dètienne \& Jacquet, 1983).

O parênquima longitudinal tem ampla variação de tipos (C. amazonica: paratraqueal ou unilateral distinto ou quase distinto sob lente; $U$. guianensis e $U$. tomentosa: apotraqueal difuso em agregados). O parênquima radial é do tipo 
unisseriado ( $U$. tomentosa), com outros autores indicando ser uni-multisseriados (Silva et al., 1998) e multisseriados (Zevallos et al., 2002). São multisseriados em $U$. guianensis e C. amazonica (séries 2-3-4), com Zevallos et al. (2002) indicando unisseriados (U. guianensis). O número de células é estável em $C$. amazonica (9-19) e variável nas espécies de Uncaria (7-42) e sua largura (20-53.32 $\mu \mathrm{m}$ em C. amazonica e 20-106,64 $\mu \mathrm{m}$ em Uncaria); freqüência (3 a 20/mm em Uncaria e 3-9/mm em $C$. amazonica).

As fibras mostram características pontoações areoladas, com comprimento e largura (1240-1690 $\mu \mathrm{m} ; 28,13-46,88 \mu \mathrm{m})$ em C. amazonica e (980-1910 $\mu \mathrm{m}$ e 18,75$46,88 \mu \mathrm{m})$ em Uncaria.

\subsubsection{Distribuição geográfica}

A distribuição latitudinal das plantas de Cinchona amazonica é mais restrita do que a das plantas de Uncaria, com ampla ocorrência na Amazônia: U. tomentosa atinge a América Central mostrando, também, a maior distribuição longitudinal, seguida de U. guianensis. Quanto ao limite altitudinal, as plantas de C. amazonica ocorrem até $1.970 \mathrm{~m}$, correspondendo a Cordilheira dos Andes, e as de U. guianensis e U. tomentosa até 1.010 e $750 \mathrm{~m}$, respectivamente (Macbride, 1936; Steyermark, 1974, Brako \& Zurucchi, 1993; Zavala \& Zevallos, 1996; Andersson, 1994, 1995 \& 1998).

Com respeito aos aspectos fisiográficos, as plantas de Cinchona amazonica ocorrem nas colinas e zonas altas, em solos bem drenados e arenosos, ao contrário das plantas de Uncaria, que são encontradas em uma variedade mais ampla de zonas de vida, sendo que as de $U$. tomentosa ocorrem sempre em solos férteis (Zavala \& Zevallos, 1996; Domínguez-Torrejón, 1997 e Zevallos et al., 2000).

Com relação aos aspectos ecológicos, as plantas de Cinchona amazônica mostram, nos levantamentos de campo, uma distribuição particular no interior das florestas primárias e em condições específicas de solo. No entanto, as plantas de $U$. guianensis ocorrem sempre nos caminhos, rodovias, trilhas, bordas de florestas primárias, florestas secundárias, beira dos rios e principalmente nos igarapés, 
geralmente em solos pobres, secos a muito úmidos. As plantas da outra espécie, $U$. tomentosa ocorrem nos igarapés e nas clareiras das florestas primárias, florestas secundárias antigas, caminhos e trilhas fechadas, em solos ricos em nutrientes e muito úmidos (Funtac, 1991; Kahn \& Ferreira, 1995; Obregón, 1995 e Zevallos et al., 2000).

\subsubsection{Status de conservação ou situação populacional}

Cinchona amazonica foi incluída na categoria CR (perigo crítico), em razão dos mesmos critérios tomados para as espécies do gênero Croton.

A inclusão das plantas de Uncaria. guianensis na categoria de LC (perigo crítico) deve-se a sua ocorrência comum e abundante, sendo caracterizada como fora de perigo de extinção. As plantas da espécie foram encontradas com freqüência e abundância no campo, nas mesmas áreas de coleta de outros pesquisadores, bem como nos registros dos herbários visitados.

As plantas de Uncaria tomentosa foram incluídas na categoria VU (vulnerável) uma vez que não se encontram em perigo de extinção imediato. A médio prazo, no entanto, as plantas poderão estar sob risco de extinção, uma vez que nas áreas em que ocorrem estão expostas a exploração florestal intensa e são de expansão da fronteira agropecuária (Zavala \& Zevallos, 1996; Lombardi \& Zevallos, 1999; Zevallos et al., 2000 e Foster et al., 2002).

As plantas de Uncaria são, da mesma forma que as de Croton, eliminadas nas práticas agrícolas por constituírem-se em espécies invasoras de áreas de agricultura e de pastagem, sendo que para U. guianensis é feita a queima das plantas seguida da extração de seu sistema radicular, para evitar a sua rebrota (Hardesty et al., 1988; Sosa \& Medrano, 1992; Obregón, 1995 e Quevedo, 1995).

Apesar de, na revisão das exsicatas nos herbários, não terem sido encontrados registros indicando a presença dessas espécies nas Unidades de Conservação do Acre, considera-se que plantas de U. guianensis e U. tomentosa devam ocorrer com relativa abundância pela sua excelente capacidade de regeneração (Flores-Bendezu, 1995b; Zavala \& Zevallos, 1996 e Melo et al., 2001). 


\section{CONCLUSÕES}

Os resultados do presente trabalho permitem concluir que:

As características dendrológicas permitem a identificação das espécies lenhosas dos gêneros Cinchona (Cinchona amazonica), Croton (Croton billbergianus, C. floribundus, C. lechleri, C. matourensis, e C. palanostigma) e Uncaria (Uncaria guianensis e U. tomentosa), ocorrentes no Estado do Acre,

A estrutura anatômica do lenho das espécies mostra características distintas e possibilita a diferenciação das espécies dos 3 gêneros,

As plantas de Cinchona amazonica mostram uma ampla distribuição no Estado do Acre,

As plantas de Croton billbergianus e C. matourensis estão bem distribuídas; as de $C$. floribundus têm ocorrência pontual; as de $C$. lechleri ocorrem somente no sudeste e as de C. palanostigma, tem distribuição quase pontual; trata-se do primeiro registro de C. floribundus no Estado do Acre,

As plantas de $U$. guianensis e $U$. tomentosa são mais freqüentes no Estado do Acre,

As plantas de Cinchona amazonica, Croton lechleri e C. palanostigma foram incluídas na categoria CR (perigo crítico); as de Croton. billbergianus, C. matourensis e Uncaria guianensis como LC (comuns e abundantes fora de perigo); as de Croton floribundus como DD (com informação disponível inadequada) e as de Uncaria tomentosa como VU (perigo a médio prazo), no Estado do Acre.

Os resultados do trabalho possibilitam apresentar as seguintes recomendações para as espécies dos 3 gêneros: 
Aplicação de métodos complementares de identificação das espécies dos 3 gêneros, como a eletroforese, fitoquímica, palinologia, anatomia da casca, dentre outros, Aprofundamento dos estudos da estrutura anatômica do lenho para a identificação, pela dificuldade na coleta de material reprodutivo na copa das árvores,

Utilização de métodos modernos de determinação da idade e da taxa de crescimento das árvores através de técnicas de dendrocronologia (anéis de crescimento) aplicados no manejo de florestas secundárias,

Desenvolvimento de avaliações tecnológicas e de usos da madeira das árvores justificando a sua manutenção nas florestas secundárias em regime de manejo florestal sustentado,

Continuidade e aprofundamento dos estudos e análises científicas sobre a aplicação medicinal das, a partir dos conhecimentos dos povos da floresta, em benefício da humanidade,

Estímulo a novas linhas de pesquisa sobre silvicultura, melhoramento e manejo das espécies e sua inclusão em programas de restauração florestal e sistemas agroflorestais e redução do extrativismo,

Indução de pesquisas e de ações de campo que visem divulgar e ampliar o uso dos produtos não madeireiros (casca, mel, fbras, látex, sementes, etc.) das florestas primárias e secundárias, possibilitando a sua manutenção, conservação e fonte de renda das comunidades das florestas,

Implantação de uma rede internacional dedicada a compilação das informações científicas sobre as espécies, propiciando a disseminação de experiências e de informações, elaboração de projetos de pesquisa conjuntos e demais atividades,

Estimular estratégias ou ações regionais com instituições governamentais, não governamentais e privadas que possuem objetivos consolidados na conservação da biodiversidade e utilização sustentável dos recursos das florestas. 
ANEXOS 
ANEXO-A

FORMULÁRIO DE DESCRIĈ̃̃O DENDROLOGICA DAS ESPÉCIES DOS GÊNEROS: CINCHONA, CROTON E UNCARIA

1. Nome científico :

2. Nome vulgar:

3. Hábito/ grupo ecológico :

4. Altura (m) :

5. Diâmetro (m) :

6. Casca externa : cor/aparência (fissura, lenticelas, anéis, outros)

8. Casca interna: cor/odor/sabor/textura (laminar, fibrosa, arenosa, outro)

9. Secreção: cor/viscosidade/quantidade/sabor/olor/outros.

10.Galhos terminais :

Seção :

Cor :

Presença de anéis, lenticelas :

Pêlos: tipo/densidade/cor :

Excrescência: tipo/densidade/cor :

11.Folhas

Pelo número de elementos foliares :

Disposição no galho terminal :

Forma:

Borde ou margem :

Tamanho :

Consistência:

Tipo de nervura:

Número de pares de nervos secundários :

Cor na parte adaxial e abaxial:

Presença de glândulas:

Pecíolo: longitude/diâmetro/presença de medula/estrias/pêlos: tipo/densidade/cor:

Cor: abaxial e adaxial :

Pêlos:

Abaxial: tipo/densidade/cor:

Adaxial: tipo/densidade/cor:

12.Inflorescências

Sexo:

Origem: terminal/axilar :

Tipo:

Número por nó:

Tamanho:

13.Flor

Cálice tipo/tamanho :

Corola tipo/tamanho:

Androceu :

Gineceu :

Brácteas :

Pêlos: tipo/densidade:

Glândulas:

14.Fruto/sementes :

15.Usos:

16. Aspectos ecológicos: 
Tabela 2. Localidades de amostragem, coleta e observação do material dendrológico e anatômico dos gêneros Cinchona, Croton e Uncaria no Estado Acre

\begin{tabular}{|c|c|c|c|c|c|c|c|c|c|}
\hline \multirow{3}{*}{$\begin{array}{l}\text { Município } \\
\text { Amostra }\end{array}$} & \multicolumn{2}{|l|}{ LOCALIDADE } & \multirow{3}{*}{$\begin{array}{l}\text { Long. } \\
\left({ }^{\circ} \mathrm{S}, \mathrm{W}\right)\end{array}$} & \multirow{3}{*}{$\begin{array}{l}\text { Alt. } \\
\text { (m) }\end{array}$} & \multirow[t]{3}{*}{ Espécie } & \multirow{2}{*}{\multicolumn{3}{|c|}{$\begin{array}{c}\text { Material } \\
\text { Coletado/observado }\end{array}$}} & \multirow[t]{3}{*}{ Número } \\
\hline & \multirow[t]{2}{*}{ Comuna } & \multirow{2}{*}{$\begin{array}{l}\text { Lat. } \\
\left({ }^{\circ} \mathrm{S}\right)\end{array}$} & & & & & & & \\
\hline & & & & & & B & A & $\mathrm{O}$ & \\
\hline Acrelândia & Perpetuo Socorro & 09o57'00"S & 66o56'24" & 125 & Uncaria guianensis & $\mathrm{X}$ & X & $\mathrm{X}$ & 2914 \\
\hline Assis Brasil & Ao redor & 10o57'30"S & 69o34'06" & 239 & Croton lechleri & & & $\mathrm{X}$ & $s / n$ \\
\hline Assis Brasil & Ao redor & 10o57'30"S & 69o34'06" & 239 & Uncaria guianensis & & & $\mathrm{X}$ & $\mathrm{s} / \mathrm{n}$ \\
\hline Brasiléia & São João & $10 \mathrm{o} 56^{\prime} 45^{\prime \prime} \mathrm{S}$ & 68o43'14" & 172 & Croton lechleri & $X$ & & $X$ & 2971 \\
\hline Brasiléia & São João+B42 & 10o56'45"S & 68o43'14" & 172 & Uncaria guianensis & & & $\mathrm{X}$ & $\mathrm{s} / \mathrm{n}$ \\
\hline Bujari Ramal & Santa Lúzia & 09o50'33"S & 67o58'53" & 150 & Croton billbergianus & $\mathrm{X}$ & & $\mathrm{X}$ & 2983 \\
\hline Bujari Ramal & Santa Lúzia & 09o50'33"S & 67o58'53" & 150 & Uncaria guianensis & $\mathrm{X}$ & & $\mathrm{X}$ & 2976 \\
\hline Capixaba & Rodovia BR-317 & 10o37'30"S & 67o37'00" & 140 & Uncaria guianensis & & & $\mathrm{X}$ & $\mathrm{s} / \mathrm{n}$ \\
\hline Cruzeiro do Sul & A-porto-Internacional & 07o37'50"S & 72o36'24" & 182 & Croton palanostigma & $X$ & $\mathrm{X}$ & $\mathrm{X}$ & 2945 \\
\hline Cruzeiro do Sul & Porto Peter & 08o10'55"S & 72o40'54" & 184 & Croton matourensis & & & $X$ & $\mathrm{~s} / \mathrm{n}$ \\
\hline Cruzeiro do Sul & Porto Peter & 08o10'55"S & 72o40'54" & 190 & Uncaria tomentosa & $X$ & $\mathrm{X}$ & $X$ & 2931 \\
\hline Cruzeiro do Sul & Porto Peter & 08o10'55"S & 72o40'54" & 190 & Uncaria guianensis & & & $\mathrm{X}$ & $\mathrm{s} / \mathrm{n}$ \\
\hline Cruzeiro do Sul & Valparaíso & 07o59'27"S & 72o40'32" & 190 & Uncaria tomentosa & $X$ & $\mathrm{X}$ & $\mathrm{X}$ & 2938 \\
\hline Cruzeiro do Sul & Carlotas & 07o58'52"S & 72o41'05" & 190 & Uncaria tomentosa & $\mathrm{X}$ & $\mathrm{X}$ & $\mathrm{X}$ & 2941 \\
\hline Epitaceolândia & Cachoeira & 10o51'21"S & 68o24'19" & 173 & Uncaria guianensis & $\mathrm{X}$ & & $\mathrm{X}$ & 2964 \\
\hline Epitaceolândia & Olho do Mundo & $11000 ' 00 " \mathrm{~S}$ & 68o29'43" & 173 & Croton lechleri & & & $\mathrm{X}$ & $\mathrm{s} / \mathrm{n}$ \\
\hline Feijó & BR-364 Km7(Fe-Ta) & 08o09'16"S & 70o22'42" & 152 & Uncaria guianensis & $\mathrm{X}$ & $X$ & $\mathrm{X}$ & 2959 \\
\hline Feijó & BR-364 Km7(Fe-Ta) & 08o09'16"S & 70o22'42" & 152 & Uncaria tomentosa & $\mathrm{X}$ & $\mathrm{X}$ & $\mathrm{X}$ & 2958 \\
\hline Mâncio Lima & Estrada a Isac Km 5 & 07o34'21"S & 72o35'08" & 195 & Cinchona amazonica & $\mathrm{X}$ & $X$ & $\mathrm{X}$ & 2925 \\
\hline Mâncio Lima & Estrada BanhoKm 5 & 07o34'22"S & 74o35'08" & 195 & Croton floribundus & $X$ & $\mathrm{X}$ & $\mathrm{X}$ & 2927 \\
\hline Mâncio Lima & Estrada a Isac Km 5 & 07o34'21"S & 72o35'08" & 195 & Uncaria guianensis & $X$ & & $\mathrm{X}$ & 2925 \\
\hline Manuel Urbano & BR-364 Km6 (Um-Sm) & 09o09'47"S & 68o39'25" & 162 & Uncaria tomentosa & $\mathrm{X}$ & & $\mathrm{X}$ & 2972 \\
\hline Manuel Urbano & BR-364 Km6 (Um-Sm) & 09o09'47"S & 68o39'25" & 162 & Uncaria tomentosa & $\mathrm{X}$ & & $\mathrm{X}$ & 2973 \\
\hline Plácido de Castro & Algodão & 10o12'01"S & 67o13'48" & 136 & Uncaria guianensis & & & $\mathrm{X}$ & $\mathrm{s} / \mathrm{n}$ \\
\hline Porto Walter & Porto Alegre & 08o02'00"S & 72o45'16" & 195 & Croton matourensis & & & $\mathrm{X}$ & $\mathrm{s} / \mathrm{n}$ \\
\hline
\end{tabular}


Tabela 2. Localidade de amostragem, coleta e observação do material dendrológico e anatômico dos gêneros Cinchona, Croton e Uncaria no Estado Acre (Continuação)

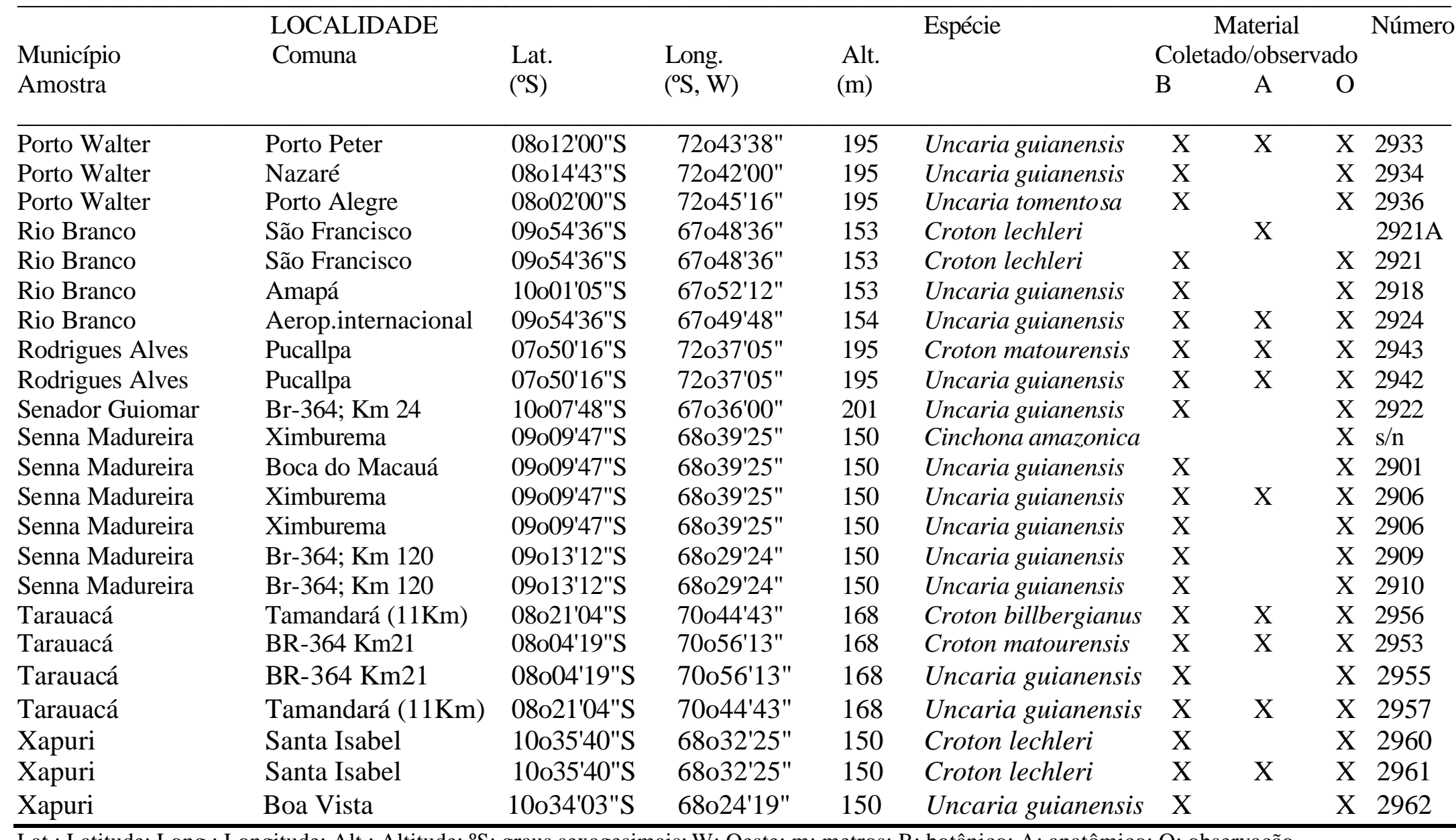

Lat.: Latitude; Long.: Longitude; Alt.: Altitude; ${ }^{\circ} \mathrm{S}$ : graus sexagesimais; W: Oeste; m: metros; B: botânico; A: anatômico; O: observação 


\begin{tabular}{|c|c|c|c|c|c|c|c|c|}
\hline \multirow[t]{2}{*}{ CARACTERISTICAS } & \multirow[b]{2}{*}{ C.amazonica } & \multirow[b]{2}{*}{ C.billbergianus } & \multicolumn{3}{|c|}{ ESPÉCIE/NÚMERO DE AMOSTRA } & \multirow[b]{2}{*}{ C. palanostigma } & \multirow[b]{2}{*}{ U. guianensis } & \multirow[b]{2}{*}{ U. tomentosa } \\
\hline & & & C. floribundus & C. lechleri & C. matourensis & & & \\
\hline Cerne/alburno & Distinto & Indistinto & Indistinto & Indistinto & Indistinto & Indistinto & Indistinto & Indistinto \\
\hline cor & $\begin{array}{l}\text { Amarelada } \\
\text { Pardo-amarelada }\end{array}$ & Branca & Amarelo-clara & Branco-acinzada & $\begin{array}{l}\text { Esbranquiçada } \\
\text { Branco-amarelada }\end{array}$ & $\begin{array}{l}\text { Esbranquiçada } \\
\text { Branco-acinzada }\end{array}$ & $\begin{array}{l}\text { Vermelho-amarelado } \\
\text { Bege-avermelhada } \\
\text { Rosa-amarelada }\end{array}$ & $\begin{array}{l}\text { Avermelhada } \\
\text { Vermelho-amarelada } \\
\text { Laranja-amarelada } \\
\text { Rosa-avermelhada }\end{array}$ \\
\hline Brilho & Moderado & Moderado & Moderado & Acentuado & Acentuado & Acentuado & Moderado & Moderado \\
\hline Odor/cheiro & Imperceptivel & Imperceptivel & Imperceptivel & Imperceptivel & Imperceptivel & Imperceptivel & Imperceptivel & Imperceptivel \\
\hline Sabor & levemente amargo & Imperceptivel & Imperceptivel & Imperceptivel & Imperceptivel & Imperceptivel & levemente amargo & Levemente amargo \\
\hline Densidade de massa & Média & Média & Média/baixa & Baixa & Baixa & Média & Média/baixa & Baixa \\
\hline Resistência ao Corte & Moderadamente dura & Macia & Macia & Macia & Macia & Macia & Moderadamente dura & Macia \\
\hline Gră & Direita & Direita & Direita & Direita & Direita & Direita & Direita & Direita \\
\hline Textura & Media & Média & Média & Média & Média & Média & Média/grossa & Media/grossa \\
\hline \multicolumn{9}{|l|}{$\begin{array}{l}\text { Camadas de crescimento } \\
\text { Vasos }\end{array}$} \\
\hline Visibilidade & A olho nu & Sob lente $10 \mathrm{x}$ & A olho nu & A olho nu & A olho nu & A olho nu & A olho nu & A olho nu \\
\hline Porosidade & Difuso & Difuso & Difuso & Difuso & Difuso & Difuso & Difuso & Difuso \\
\hline Arranjo & Radial & Radial & Radial & Radial & Radial & Radial & Radial & Radial \\
\hline \multicolumn{9}{|l|}{ Agrupamento de vasos (\%) } \\
\hline Solitários & 59.52 & 85.42 & 41.18 & 26.67 & 85.71 & 35.71 & 64.29 & 96.15 \\
\hline Múltiplos & 40.48 (2,3 ои 4$)$ & $14.58[2,3,4(5)]$ & $8.82[2,3$ ou $(4)]$ & $73.33[(2-3$ ou $(4)]$ & $14.29[2-3(4)]$ & $64.29[2(3-4)]$ & $35.71(2-3)$ & $3.85[2-(3)]$ \\
\hline $\begin{array}{l}\text { Freqüencia }\left(\# / \mathrm{mm} m^{2}\right) \\
\text { Diámetro tangencial do lume }(\mu \mathrm{m})\end{array}$ & 14-18 & $16-26$ & $16-21$ & $5-9$ & 3-8 & 4-18 & $3-13$ & 3-8 \\
\hline Mínimo & 66.65 & 53.32 & 20.00 & 66.65 & 86.64 & 93.31 & 106.64 & 119.97 \\
\hline Médio & 81.31 & 73.32 & 55.32 & 149.30 & 166.96 & 121.30 & 308.70 & 334.08 \\
\hline Máximo & 119.97 & 106.64 & 106.64 & 239.94 & 213.28 & 159.96 & 453.22 & 613.18 \\
\hline Desvio padrão & 20.31 & 20.12 & 24.35 & 50.97 & 36.86 & 26.99 & 91.48 & 110.62 \\
\hline Forma da seção & Arredondada & Arredondada & Arredondada & Arredondada & Arredondada & Arredondada & Arredondada & Arredondada \\
\hline \multicolumn{9}{|l|}{ Comprimento $(\mu \mathrm{m})$} \\
\hline Minimo & 666.50 & 333.25 & 373.24 & 266.60 & 159.96 & 466.55 & 293.26 & 239.94 \\
\hline Médio & 1001.06 & 562.53 & 581.19 & 581.19 & 716.49 & 543.86 & 598.96 & 509.21 \\
\hline Máximo & 1599.60 & 906.44 & 933.10 & 826.46 & 1053.07 & 733.15 & 826.46 & 866.45 \\
\hline \multirow{2}{*}{\multicolumn{9}{|c|}{ Apênndices }} \\
\hline & & & & & & & & \\
\hline Tamanho $[f(c o m p r i m e n t o ~ v a s o)]]$ & Curtos $<1 / 3$ & Curtos $<1 / 3$ & Curtos $<1 / 3$ & Curtos $<1 / 3$ & Curtos $<1 / 3$ & Curtos $<1 / 3$ & Curtos $<1 / 3$ & Curtos $<1 / 3$ \\
\hline Extremidades & Ambas & Ambas & Ambas & Ambas & Ambas & Ambas & Ambas & Ambas \\
\hline Placas de perfuração & Simples & Simples & Simples & Simples & Simples & Simples & Simples & Simples \\
\hline Depósitos em vasos & $\begin{array}{l}\text { Indistinto } \\
\text { Into }\end{array}$ & Distinto & $\begin{array}{l}\text { Distinto } \\
\text { Disto }\end{array}$ & Distinto & Distinto & Distinto & Distinto & $\begin{array}{l}\text { Distinto } \\
\text { Dinto }\end{array}$ \\
\hline 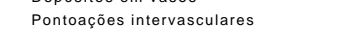 & Areoladas & Areoladas & Areoladas & Areoladas & Areoladas & Areoladas & Areoladas & Areoladas \\
\hline Arranjo & Alternas & Alternas & Alternas & Alternas & Alternas & Alternas & Alternas & Alternas \\
\hline Formas & Arredondadas & $\begin{array}{l}\text { Predominantemente } \\
\text { poligonal e } \\
\text { arredondadas }\end{array}$ & $\begin{array}{l}\text { Predominantmente } \\
\text { arredondada e } \\
\text { poligonal }\end{array}$ & Poligonal & $\begin{array}{l}\text { Predominantemente } \\
\text { poligonale } \\
\text { arredondadas }\end{array}$ & $\begin{array}{l}\text { Predominantemente } \\
\text { poligonale } \\
\text { arredondadas }\end{array}$ & Arredondada & Arredondada \\
\hline Abundância & Sim & & & sim & Sim & Sim & $\operatorname{sim}$ & \\
\hline Ornamentaçöes & Ausente & Ausente & Ausente & Ausente & Ausente & Ausente & Ausente & Ausente \\
\hline \multicolumn{9}{|l|}{ Diâmetro tangencial } \\
\hline Minimo & 4.08 & 3.99 & 3.87 & 5.26 & 4.67 & 3.98 & 4.25 & 3.69 \\
\hline Médio & 5.05 & 4.59 & 4.56 & 7.42 & 6.66 & 5.23 & 5.56 & 6.30 \\
\hline Máximo & 8.56 & 5.02 & 6.85 & 8.84 & 8.45 & 7.65 & 7.11 & 8.05 \\
\hline Desvio padrāo & 0.61 & 0.28 & 0.78 & 0.49 & 0.92 & 1.88 & 0.36 & 0.91 \\
\hline
\end{tabular}


Tabela 3. Resumo da caracterização da anatomia do lenho das espécies do gênero Cinchona, Croton e Uncaria

(Continuação)

\begin{tabular}{|c|c|c|c|c|c|c|c|c|}
\hline \multirow[t]{2}{*}{ CARACTERISTICAS } & \multicolumn{7}{|c|}{ ESPÉCIE/NÚMERO DE AMOSTRA } & \multirow[b]{2}{*}{ U. tomentosa } \\
\hline & C.amazonica & C.billbergianus & C. floribundus & C. lechleri & C. matourensis & C. palanostigma & U. guianensis & \\
\hline Pontoaçōes raio-vasculares & Areoladas & Areoladas & Areoladas & Areoladas & Areoladas & Areoladas & Areoladas & Areoladas \\
\hline Arranjo & Alternas & Indistinto & Alternas & Alternas & Alternas & Alternas & Alternas & Alternas \\
\hline Formas & Arredondadas & Indistinto & Arredondadas & Arredondadas & Arredondadas & Arredondadas & Arredondadas & Arredondadas \\
\hline \multicolumn{9}{|l|}{ Diâmetro tangencial } \\
\hline Mínimo & 2.65 & Indistinto & 3.68 & 2.88 & 3.19 & 1.99 & 4.12 & 4.25 \\
\hline Médio & 4.01 & Indistinto & 4.41 & 3.95 & 4.68 & 3.63 & 5.67 & 5.94 \\
\hline Máximo & 5.05 & Indistinto & 5.21 & 4.78 & 6.03 & 4.84 & 6.57 & 7.25 \\
\hline Desvio padrão & 0.40 & Indistinto & 0.41 & 0.56 & 0.79 & 0.63 & 0.75 & 0.98 \\
\hline \multicolumn{9}{|c|}{ Pontuaçōes parênquimo-vasculares } \\
\hline \multirow{3}{*}{$\begin{array}{l}\text { Arranjo } \\
\text { Formas }\end{array}$} & Alternas & Alternas & Alternas & Alternas & Alternas & Alternas & Alternas & Alternas \\
\hline & Arredondadas & \multirow{2}{*}{\multicolumn{3}{|c|}{$\begin{array}{l}\text { Predominantemente poligi Predominantmente arredo Poligonal } \\
\begin{array}{l}\text { earredondadas } \\
\text { e poligonal }\end{array}\end{array}$}} & \multicolumn{3}{|c|}{ Predominantemente poligc Predominantemente poligcArredondada } & Arredondada \\
\hline & & & & & Arredondadas & Arredondadas & & \\
\hline Abundâncias & sim & Sim & $\operatorname{sim}$ & $\operatorname{sim}$ & sim & $\operatorname{sim}$ & sim & sim \\
\hline $\begin{array}{l}\text { Diâmetro tangencial } \\
\text { Mínimo }\end{array}$ & Ausente & Ausente & Ausente & Ausente & Ausente & Ausente & Ausente & Ausente \\
\hline Médio & 4.08 & 3.99 & 3.87 & 5.26 & 4.67 & 3.98 & 4.25 & 3.69 \\
\hline Máximo & 5.05 & 4.59 & 4.56 & 7.42 & 6.66 & 5.23 & 5.56 & 6.30 \\
\hline Desvio padrão & 8.56 & 5.02 & 6.85 & 8.84 & 8.45 & 7.65 & 7.11 & 8.05 \\
\hline Pontoações das fribras & 0.61 & 0.28 & 0.78 & 0.49 & 0.92 & 1.88 & 0.36 & 0.91 \\
\hline Arranjo & Alternas & Alternas & Alternas & Alternas & Alternas & Alternas & Alternas & Alternas \\
\hline Formas & Arredondadas & Arredondadas & Arredondadas & Arredondadas & Arredondadas & Arredondadas & Arredondadas & Arredondadas \\
\hline Abundâncias & Alta nas 2 sẹ̄ōes & Muito alta = radial & Pouca $=$ radial & Alta - radial & Pouca $=$ radial & Pouca $=$ radial & Muito nas 2 seçōes & Muito nas 2 seçōes \\
\hline \multicolumn{9}{|l|}{ Diâmetro tangencial } \\
\hline Mínimo & 2.56 & 2.79 & 2.02 & 2.49 & 2.22 & 0.56 & 4.35 & 4.19 \\
\hline Médio & 4.74 & 3.05 & 3.22 & 4.03 & 3.74 & 0.97 & 6.13 & 6.07 \\
\hline Máximo & 5.87 & 4.89 & 4.45 & 5.64 & 5.26 & 1.42 & 7.56 & 7.87 \\
\hline Desvio padrão & 0.60 & 0.45 & 0.58 & 0.67 & 0.64 & 0.27 & 0.77 & 0.58 \\
\hline \multicolumn{9}{|l|}{ Fibras } \\
\hline \multirow{2}{*}{\multicolumn{9}{|c|}{$\begin{array}{l}\text { Tipo } \\
\text { Comprimento }(\mu \mathrm{m})+B 100\end{array}$}} \\
\hline & & & & & & & & \\
\hline Mínimo & 1240 & 760 & 860 & 1260 & 950 & 780 & 1110 & 980 \\
\hline Médio & 1520 & 1010 & 1040 & 1310 & 1195 & 1120 & 1483 & 509 \\
\hline Máximo & 1690 & 1190 & 1410 & 1370 & 1410 & 1300 & 1910 & 1760 \\
\hline Desvio padrão & 160 & 180 & 200 & 40 & 150 & 170 & 101 & 110 \\
\hline Largura $(\mu \mathrm{m})$ & $28.13-46.88$ & $18.75-40.63$ & $18.75-34.38$ & $25.00-34.38$ & $25.00-40.63$ & $15.63-28.13$ & $18.75-43.75$ & $18.75-46.88$ \\
\hline Espessura da parede & Delgada & Delgada & Delgada & Delgada & Delgada & Delgada & Delgada & Delgada/espessa \\
\hline \multicolumn{9}{|l|}{ Parênquima axial } \\
\hline Visibilidade & invisíveis & A olho nu & A olho nu & A olho nu & A olho nu & Sob lente $10 \mathrm{x}$ & invisiveis & invisiveis \\
\hline Disposiçăo & $\begin{array}{l}\text { Paratraqueal escasso } \\
\text { ou unilateral }\end{array}$ & Em faixas o linhas .... (C) & Em faixas o linhas .... (C) & Em faixas o linhas .... (C) & Em faixas o linhas .... (C) & Em faixas o linhas. & $\begin{array}{l}\text {.. (C) Paratraqueal escasso } \\
\text { ou unilateral }\end{array}$ & $\begin{array}{l}\text { Paratraqueal escasso } \\
\text { ou unilateral }\end{array}$ \\
\hline Tipo de células & Seriado & Seriado & Seriado & Seriado & Seriado & Seriado & Seriado & Seriado \\
\hline \multicolumn{9}{|l|}{ Parênquima radial (raios) } \\
\hline Visibilidade & Sob lente $10 \mathrm{x}$ & Sob lente $10 x$ & A olho nu & A olho nu & & A olho nu & invisíveis & invisiveis \\
\hline \multicolumn{9}{|l|}{ Largura (\%) } \\
\hline Unisseriado & 45.45 & 92.31 & 94.74 & 61.54 & 66.67 & 56.25 & 65.71 & 63.16 \\
\hline Multisseriado & $54.55(2$, raro 3-4) & $7.69(2)$ & $5.26(2)$ & $38.46(2)$ & $33.33(2)$ & $43.75(2)$ & $34.29(2-(3-4))$ & $36.84(+2)$ \\
\hline
\end{tabular}




\begin{tabular}{|c|c|c|c|c|c|c|c|c|}
\hline \multirow[t]{2}{*}{ CARACTERISTICAS } & \multicolumn{7}{|c|}{ FSPF́CIFNI ÍMFRO DF. AMOSTRA } & \multirow[b]{2}{*}{ U. tomentosa } \\
\hline & C.amazonica & C.billbergianus & C. floribundus & C. lechleri & C. matourensis & C. palanostigma & U. guianensis & \\
\hline \multicolumn{9}{|l|}{ Altura (mm) } \\
\hline Mínimo & 4.99 & 4.99 & 3.25 & 1.73 & 3.90 & 3.25 & 3.25 & 3.25 \\
\hline Médio & 7.10 & 6.86 & 4.12 & 2.69 & 6.78 & 5.37 & 7.52 & 6.69 \\
\hline Máximo & 9.76 & 9.76 & 4.34 & 3.91 & 10.85 & 8.46 & 11.93 & 11.93 \\
\hline Desvio padrão & 1.53 & 3.23 & 1.55 & 1.35 & 3.12 & 2.59 & 4.68 & 3.25 \\
\hline \multicolumn{9}{|l|}{ Freqüencia (\#/mm²) } \\
\hline Mínimo & 3 & 11 & 9 & 7 & 8 & 7 & 6 & 3 \\
\hline Médio & 6.00 & 12.60 & 9.80 & 8.10 & 8.80 & 8.60 & 13.50 & 8.90 \\
\hline Máximo & 9 & 15 & 11 & 9 & 10 & 10 & 20 & 16 \\
\hline Desvio padrão & 2.16 & 1.43 & 0.92 & 0.88 & 1.03 & 1.17 & 4.93 & 4.65 \\
\hline Composição & Heterocelular & Heterocelular & Heterocelular & Heterocelular & Heterocelular & Heterocelular & Heterocelular & Heterocelular \\
\hline \multicolumn{9}{|l|}{ Tipo de células } \\
\hline Procumbentes & $9(53.09 \%)$ & $9(55.55 \%)$ & $12(69.41 \%)$ & $13(74.72 \%)$ & $11(67.08 \%)$ & $12(60.78 \%)$ & $11(43.75 \%)$ & $11(45.16 \%)$ \\
\hline \multicolumn{9}{|l|}{ Eretas } \\
\hline -Acima & $4(23.46 \%)$ & $3(20.99 \%)$ & $3(20 \%)$ & $2(10.34 \%)$ & $3(16.46 \%)$ & $5(23.53 \%)$ & $8(32.03 \%)$ & $5(20.16 \%)$ \\
\hline - Embaixo & $4(23.46 \%)$ & $4(23.46 \%)$ & $2(10.59 \%)$ & $3(14.94 \%)$ & $3(16.46 \%)$ & $3(15.69 \%)$ & $6(24.22 \%)$ & $9(34.68 \%)$ \\
\hline Número de linhas & $9-19$ & 8-32 & $13-23$ & $8-23$ & $5-23$ & $4-25$ & $7-30$ & $7-42$ \\
\hline$\underline{\text { Largura }(\mu \mathrm{m})}$ & $20.00-53.32$ & 1.07-26.66 & 13.33-26.66 & 13.33-39.99 & $13.33-26.66$ & $20.00-39.00$ & 26.66-106.64 & $20.00-106.64$ \\
\hline
\end{tabular}

A : Fibras com pontoaçōes distintamente areoladas maior que $3 \mu \mathrm{m}$

B: Fibras com pontoações simples a areoladas muito pequenas menor que $3 \mu \mathrm{m}$

C: Parênquima em faixas estreitas ou linhas com menos de 3 células de largura 
Informacão do material botânico nos herbários do gênero Cinchona

\begin{tabular}{|c|c|c|c|c|c|c|c|c|c|c|c|c|}
\hline \multirow{3}{*}{$\begin{array}{l}\text { Espécie } \\
\text { N.científico } \\
\text { Cinchona amazonica Standl. }\end{array}$} & \multirow{3}{*}{$\frac{\text { N. vulgar }}{-}$} & \multirow{3}{*}{$\begin{array}{l}\begin{array}{l}\text { Herbário } \\
\text { Sigla }\end{array} \\
\text { SP }\end{array}$} & \multirow[b]{2}{*}{ Registro } & \multicolumn{2}{|l|}{ Localidade } & \multirow[b]{2}{*}{ Município } & \multirow[b]{2}{*}{$\begin{array}{l}\text { Latitude } \\
\quad \text { (eS.S) } \\
\end{array}$} & \multirow[b]{2}{*}{$\begin{array}{c}\text { Longitude } \\
\left({ }^{\circ} \mathrm{S} . \mathrm{W}\right) \\
\end{array}$} & \multirow[b]{2}{*}{$\begin{array}{l}\text { Altitude } \\
\text { manm }\end{array}$} & COLETOR & \multirow{2}{*}{\multicolumn{2}{|c|}{ Data }} \\
\hline & & & & País & Estado & & & & & e Nome/número & & \\
\hline & & & 23499 & 4 Brasil & Acre & Buiari & 09042'53"S & 68008'27" & & 150 J.M. ${ }^{a}$ de Souza & 116 & $6 / 14 / 8$ \\
\hline Cinchona amazonica Standl. & & $\mathrm{NY}$ & $\mathrm{sn}$ & Brasil & Acre & Cruzeiro do Sul & $07038^{\prime} 00 " \mathrm{~S}$ & $720366^{\prime} 00^{\prime \prime}$ & & 150 I. R. Marinho & 137 & $2 / 12 / 71$ \\
\hline Cinchona amazonica Standl. & - & IFAC & $\mathrm{sn}$ & Brasil & Acre & Mâncio I ima & 07037'00"S & $7205555 "$ & & 195 C.A Ferreira et al. & 10962 & $3 / 25 / 9$ \\
\hline Cinchona amazonica Standl. & - & UFAC & & Brasil & Acre & Mâncio Lima & 07o3600"S & 72057'00" & & 195 D.C. Dolv & 9047 & $5 / 13 / 9$ \\
\hline Cinchona amazonica Standl. & - & HEO & 3630 & 0 Brasil & Acre & Rio Branco & 09058'00"S & $67048^{\prime} 00^{\prime \prime}$ & & 153 Froes R. & 22962 & 2/6/4i \\
\hline Cinchona amazonica Standl & - & HFO & 2907 & 5 Rrasil & Amaznnas & Firunené & 07n35'no"s & 70ก10'วา:" & -- & Frnes $\mathrm{R}$ & $2.168 ?$ & $10 / 3 / 41$ \\
\hline Cinchona amazonica Standl. & - & $\mathrm{RB}$ & 26650 & 4 Rrasil & Amaznnas & Humaitá & 07045'nn"s & 53.16'0n" & & $70 \mathrm{I}$ aa Teixeira et al & 1171 & $6 / 17 / 8^{\prime}$ \\
\hline Cinchona amazonica Standl. & - & $\mathrm{R}$ & 18034 & 5 Brasil & Amazonas & Manaus & 02019'00"S & $60005^{\prime} 00^{\prime \prime}$ & & sc & sn & $11 / 21 / 7$ \\
\hline Cinchona amazonica Standl. & - & SPF & 13178 & 1 Brasil & Amazonas & Manaus & 02o24'31"S & $59044^{\prime} 45^{\prime \prime}$ & & 80 S.G. Egler et al. & 1588 & 00/03/199: \\
\hline Cinchona amazonica Standl & - & $\mathrm{Mr}$ & 4843 & 9 Rrasil & Amaznnas & Manaıs & mo19'nn"s & 60กกร'00" & & $12.5 \mathrm{I}$ leras ef al & $\mathrm{sn}$ & $11 / 21 / 7^{\prime}$ \\
\hline Cinchona amazonica Standl & - & HFO & 3655 & 5 Rrasil & Amaznnas & Manaus & mo19'nn"s & 60กกร'no" & & 12.5 Frnes $\mathrm{R}$ & 23286 & $6 / 24 / 4:$ \\
\hline Cinchona amazonica Standl. & - & INPA & 4306 & 9 Rrasil & Amaznnas & Manaus & mก:4'31"s & $59044^{\prime} 45^{\prime \prime}$ & & $80 \mathrm{I}$ leras $\mathrm{F}$ & 19585 & $11 / 21 / 7^{\prime}$ \\
\hline Cinchona amazonica Standl. & - & INPA & 3642 & 5 Rrasil & Amaznnas & Manans & Mก53'On"s & 59กร8' & --- & Silva M & 334 & $7 / 10 / 7$ \\
\hline Cinchona amazonica Standl. & - & SP & $32080^{-}$ & 7 Brasil & Amazonas & Manaus & 02019'00"S & $60005^{\circ} 00^{\prime \prime}$ & & 125 S.G. Eger et al. & s.n & 00/03/199: \\
\hline Cinchona amazonica Standl. & - & MG & 14965 & 1 Brasil & Pará & Alto Tanains & 08000'00"s & $5700500 "$ & & 250 Cordeiro M. & 2247 & $10 / 31 / 9$ \\
\hline Cinchona amazonica Standl. & - & $\mathrm{R}$ & 18029 & 5 Brasil & Roraima & Santa Rosa & $0301000 " \mathrm{~N}$ & $\left.60050^{\prime} 00\right)^{\prime \prime}$ & & G.T. Prance et al & 20001 & $12 / 3 / 7$ \\
\hline Cinchona amazonica Standl. & - & INPA & 4392 & 6 Brasil & Roraima & Santa Rosa & $03010100 " \mathrm{~N}$ & $60050^{\prime} 00^{\prime \prime}$ & -- & Prance G. & 20001 & $12 / 3 / 7$ \\
\hline Cinchona amazonica Standl. & - & MG & 4866 & 7 Brasil & Roraima & Santa Rosa & $03010^{\prime} 00 " \mathrm{~N}$ & $60050^{\prime} 00^{\prime \prime}$ & --- & Prance G. & 20001 & $12 / 3 / 7$ \\
\hline Cinchona amazonica Standl. & - & $\mathrm{RB}$ & 17366 & 6 Brasil & Roraima & Surucucu & $02053^{\prime} 00^{\prime \prime} \mathrm{N}$ & $6303600 "$ & & N. ${ }^{\text {a }}$ Rosa & 311 & 1/26/7: \\
\hline Cinchona amazonica Standl & - & INPA & 8547 & 3 Colômhia & Amaznnas & -- & n1nก0'nn"s & 7)กnก'no" & --- & Acern $\mathrm{F}$. & 939 & 2/9/7 \\
\hline Cinchona amazonica Standl. & - & HFO & 8605 & G Colômbia & Vaunés & -- & $00015 " 00 " \mathrm{~N}$ & $69045^{\prime} 00 "$ & & 180 Fernandez A. & 2140 & $2 / 4 / 5$ \\
\hline Cinchona amazonica Standl. & - & USM & 14283 & 7 Peru & Cusce. & Paucatambo & 1301700"S & $70048^{\prime} 00 "$ & & 720 Timaná M. & 1201 & 29/1 1/1991 \\
\hline Cinchona amazonica Standl. & - & AMAZ & 2131 & 4 Peru & Loreto & Mavnas & 03048'00"S & $73025^{\prime} 00^{\prime \prime}$ & & 122 Vasquez R. & 4577 & 11/9/8: \\
\hline Cinchona amazonica Standl. & - & USM & 9635 & 6 Peru & Loreto & Ucavali & $04055^{\circ} 00^{\prime \prime S}$ & 73o45'00" & & 130 Daza A. & $1855 \mathrm{AD}$ & $27 / 11 / 200$ \\
\hline Cinchona amazonica Standl & & $\mathrm{Mn}$ & sn & Pern & Pasen & Oxanamna & 10ก3?'กn"s & 75nก5'100" & & $780 \mathrm{Al}$ Gentrv et al $6375 ?$ & & $7 / 4 / 8:$ \\
\hline Cinchona amazonica Standl & - & AMA7. & $1657^{\circ}$ & 7 Peru & Рasen & Oxanamna & 10n35'0n"s & 75กว8' $10 "$ & & 1970 Smitth D & 1635 & $5 / 79 / 8$ \\
\hline Cinchona amazonica Standl. & $\ldots$ & USM & 6829 & 6 Peru & Pasco & Oxapampa & $10019^{\prime} 00^{\prime \prime} \mathrm{S}$ & $7501600^{\prime \prime}$ & & 450 Foster R. et al. & 10175 & 13/05/198: \\
\hline
\end{tabular}


Informação do material botânico nos herbários do gênero Croton

\begin{tabular}{|c|c|c|c|c|c|c|c|c|c|c|c|c|}
\hline \multirow{2}{*}{$\begin{array}{l}\text { Espécie } \\
\text { N.científico }\end{array}$} & \multirow[b]{2}{*}{ N. vulgar } & \multicolumn{2}{|l|}{ Herbário } & \multicolumn{2}{|l|}{ Localidade } & \multirow[b]{2}{*}{ Município } & \multirow[b]{2}{*}{$\begin{array}{c}\text { Latitude } \\
\text { (s.S.S) }\end{array}$} & \multirow[b]{2}{*}{$\begin{array}{r}\text { Longitude } \\
\left({ }^{\circ} \mathrm{S}, \mathrm{W}\right) \\
\end{array}$} & \multicolumn{2}{|r|}{ COLETOR } & \multirow{2}{*}{\multicolumn{2}{|c|}{ Data }} \\
\hline & & Sigla & Registro & País & Estado & & & & $\begin{array}{l}\text { Altitude } \\
\text { (manm) }\end{array}$ & e Nome/número & & \\
\hline Croton billbergianus Müell.Arg. & & мо & **** & Bélize & Cayo & --- & $16050^{\circ} 00^{\prime \prime N}$ & $88055^{\prime} 00^{\prime \prime}$ & & $60 \mathrm{Al}$ Gentry 8439 & & $1 / 21 / 73$ \\
\hline Croton billbergianus Müell.Arg. & Velame & $\mathrm{INPA}^{*}$ & & 161327 Brasil & Acre & Cruzeiro do Sul & $08036^{\circ} 00^{\prime \prime} \mathrm{S}$ & 73010'00" & & 190 Ferreira M. & 50 & $10 / 11 / 87$ \\
\hline Croton billbergianus Müell.Arg. & -- & MG* & & 49534 Brasil & Acre & Porto Acre & $09035^{\prime} 00^{\prime \prime} \mathrm{S}$ & 67035'00" & -- & Kuhlmann J. & 687 & $10 / 22 / 23$ \\
\hline Croton billbergianus Müell.Arg. & - & $\mathrm{MG}^{*}$ & & 49536 Brasil & Acre & Rio Branco & $10001^{\prime} 05 " \mathrm{~S}$ & 67052'12" & & 153 Kuhlmann J. & 723 & $10 / 26 / 23$ \\
\hline Croton billbergianus Müell.Arg. & -- & MG* $^{*}$ & & 39251 Brasil & Acre & Sena Madureira & $09012^{\prime} 00^{\prime \prime} \mathrm{S}$ & 68044'00" & & 150 Prance G.. & 7933 & $10 / 8 / 68$ \\
\hline Croton billbergianus Müell.Arg. & -- & $\mathrm{R}^{*}$ & & 10430 Brasil & Amazonas & -.. & $02019^{\prime} 00^{\prime \prime S}$ & 60005'00" & & 125 J.G.Kuhlmann & 2106 & $00 / 08 / 1962$ \\
\hline Croton billbergianus Müell.Arg. & -- & MG* & & 10567 Brasil & Pará & Belém & -.- & -- & -- & Ducke A. & sn & $1 / 31 / 10$ \\
\hline Croton billbergianus Müell.Arg. & -- & $\mathrm{R}^{*}$ & & 2418 Brasil & Pará & Cuminá-Mirim & -.. & -- & -- & "Ducke & 1946 & $00 / 08 / 1961$ \\
\hline Croton billbergianus Müell.Arg. & -- & MG* $^{*}$ & & 35609 Brasil & Pará & Santarém & -.- & -- & & 350 Rodríques $\mathrm{W}$. & 5130 & $4 / 6 / 63$ \\
\hline Croton billbergianus Müell.Arg. & -- & INPA* & & 111126 Brasil & Rondônia & Porto Velho & $09000^{\prime} 00 " \mathrm{~s}$ & 62044'05" & & 115 Freitas C. & 119 & 2/14/83 \\
\hline Croton billbergianus Müell.Arg. & & HUA & **** & Colômbia & Antioquia & $\cdots$ & $\cdots$ & & & 365 E.Renteria 2348 & & 6/19/80 \\
\hline Croton billbergianus Müell.Arg. & & $\mathrm{CR}$ & **** & Costa Rica & -.- & $\ldots$ & $09045^{\circ} 00 " \mathrm{~N}$ & $84033^{\prime} 00^{\prime \prime}$ & & 690 E.Bello 2305 & & $7 / 2 / 90$ \\
\hline Croton billbergianus Müell.Arg. & & мо & **** & Costa Rica & Alajuela & -.. & $10030^{\circ} 00^{\prime \prime} \mathrm{N}$ & $84030^{\circ} 00^{\prime \prime}$ & & William A et al. 1688 & & 6/29/85 \\
\hline Croton billbergianus Müell.Arg. & & мо & **** & Costa Rica & Alajuela & $\ldots$ & $10030^{\prime} 00^{\prime \prime} \mathrm{N}$ & $84030^{\circ} 00^{\prime \prime}$ & & 100 T.B.Croat 36352 & & $1 / 25 / 76$ \\
\hline Croton billbergianus Müell.Arg. & & мо & $* * * *$ & Costa Rica & Alajuela & $\cdots$ & $10030^{\circ} 00^{\prime \prime} \mathrm{N}$ & $84030^{\prime} 00^{\prime \prime}$ & & 250 William A. et al. s/n & & $6 / 27 / 85$ \\
\hline Croton billbergianus Müell.Arg. & & мо & $* * *$ & Costa Rica & Alajuela & -.. & $10012^{4} 40 " \mathrm{~N}$ & $84036^{\prime} 20^{\prime \prime}$ & & 950 J.Bittner 636 & & 2/6/91 \\
\hline Croton billbergianus Müell.Arg. & & $\mathrm{CR}$ & **** & Costa Rica & Alajuela & -.. & $10044^{2} 20 " \mathrm{~N}$ & $85003^{\prime 2} 20^{\prime \prime}$ & & 550 J.González et al. s/n & & 8/2/94 \\
\hline Croton billbergianus Müell.Arg. & -- & MG & & 139226 Costa Rica & Alajuela & $\cdots$ & -.- & -- & & 250 Haber $\mathrm{W}$. & 1851 & $6 / 27 / 85$ \\
\hline Croton billbergianus Müell.Arg. & & MO & $* * * *$ & Costa Rica & Guanacaste & $\cdots$ & $11002^{2} 00^{\prime} \mathrm{N}$ & 85024'30" & & 450 W P.Ríos 17 & & 9/12/90 \\
\hline Croton billbergianus Müell.Arg. & & мо & **** & Costa Rica & Heredia & -.. & $1001700 " \mathrm{~N}$ & $84002^{\prime} 00^{\prime \prime}$ & & 400 O.Vargas 161 & & 9/21/89 \\
\hline Croton billbergianus Müell.Arg. & & мо & **** & Costa Rica & Limón & -.. & $09040^{\prime} 30^{\prime \prime} \mathrm{N}$ & $83000^{\prime 2} 20^{\prime \prime}$ & & 100 w.Carballo 493 & & 9/14/93 \\
\hline Croton billbergianus Müell.Arg. & & $\mathrm{CR}$ & **** & Costa Rica & Limón & $\cdots$ & $09040^{\prime} 30^{\circ} \mathrm{N}$ & 83001'25" & & 100 G.Gallardo 131 & & 4/1/4/94 \\
\hline Croton billbergianus Müell.Arg. & & $\mathrm{CR}$ & $* * * *$ & Costa Rica & Limón & $\cdots$ & $10012^{\prime} 00 " \mathrm{~N}$ & 83051'50" & & 280 Q.Jiménez 1665 & & 10/8/94 \\
\hline Croton billbergianus Müell.Arg. & & мо & **** & Costa Rica & Limón & -.. & $10012^{\prime} 00^{\prime \prime} \mathrm{s}$ & $83052^{\prime} 00^{\prime \prime}$ & & 300 M.H.Grayum et al. 3282 & & $6 / 16 / 84$ \\
\hline Croton billbergianus Müell.Arg. & & INB & **** & Costa Rica & Limón & -.. & $10011^{\prime} 00 " \mathrm{~N}$ & 83053'00" & & 250 R. Aguilar 640 & & 10/27/94 \\
\hline Croton billbergianus Müell.Arg. & & $\mathrm{CR}$ & **** & Costa Rica & Limón & $\cdots$ & 10011 '55"N & 83053'20" & & 250 J. González et al. s/n & & $11 / 3 / 94$ \\
\hline Croton billbergianus Müell.Arg. & & мо & **** & Costa Rica & Limón & -.. & $10012^{\prime} 00^{\prime N} \mathrm{~N}$ & $83054^{\prime} 00^{\prime \prime}$ & & 400 M.H Grayum et al.s/n & & 7/19/84 \\
\hline Croton billbergianus Müell.Arg. & & $\mathrm{CR}$ & **** & Costa Rica & Limón & -.. & $10009^{\prime} 50 " \mathrm{~N}$ & 83057'30" & & 750 E.López et al. 28 & & $5 / 18 / 93$ \\
\hline Croton billbergianus Müell.Arg. & & INB & **** & Costa Rica & Puntarenas & -.. & $08028^{\prime} 00^{\prime \prime} \mathrm{N}$ & $83035^{\prime} 00^{\prime \prime}$ & & 10 R.Aguilar 3529 & & $7 / 27 / 94$ \\
\hline Croton billbergianus Müell.Arg. & & $\mathrm{CR}$ & **** & Costa Rica & Puntarenas & -.. & $09047^{\circ} 00^{\prime \prime N}$ & 84032'30" & & 130 M.Grayum et al. 10529 & & $4 / 5 / 93$ \\
\hline Croton billbergianus Müell.Arg. & & мо & **** & Costa Rica & Puntarenas & -.. & $09045^{\circ} 00^{\prime \prime} \mathrm{N}$ & 84033'50" & & $500 \mathrm{~W}$ Rojas 120 & & $7 / 23 / 90$ \\
\hline Croton billbergianus Müell.Arg. & & $\mathrm{CR}$ & $* * *$ & Costa Rica & Puntarenas & --- & $09046^{\circ} 00^{\prime} \mathrm{N}$ & $84036^{\circ} 00^{\prime \prime}$ & & 30 E.Bello et al. 2272 & & $6 / 26 / 90$ \\
\hline Croton billbergianus Müell.Arg. & & $\mathrm{CR}$ & **** & Costa Rica & Puntarenas & -.. & $09046^{\circ} 00^{\prime \prime} \mathrm{N}$ & $84036^{\circ} 00^{\prime \prime}$ & & 30 E.Bello et al. 2274 & & $6 / 26 / 90$ \\
\hline Croton billbergianus Müell.Arg. & & мо & **** & Costa Rica & Puntarenas & $\cdots$ & $0904630 " \mathrm{~N}$ & $84036^{\circ} 00^{\prime \prime}$ & & 100 Rojas 68 & & 6/26/90 \\
\hline Croton billbergianus Müell.Arg. & & мо & **** & Costa Rica & Puntarenas & -.. & $0904750 " \mathrm{~N}$ & 84036'30" & & 30 Ramirez 381 & & $7 / 6 / 95$ \\
\hline Croton billbergianus Müell.Arg. & & мо & **** & Costa Rica & San José & -.. & $09045^{\prime} 30 " \mathrm{~N}$ & $84033^{\prime} 00^{\prime \prime}$ & & 550 M.H. Grayum et al. 5883 & & $8 / 7 / 85$ \\
\hline Croton billbergianus Müell.Arg. & & мо & **** & Costa Rica & San José & -.. & $09045^{\circ} 00^{\prime \prime} \mathrm{N}$ & $84034^{\prime} 00^{\prime \prime}$ & & 430 M.H. Grayum et al. 5511 & & $6 / 26 / 85$ \\
\hline Croton billbergianus Müell.Arg. & -- & MG & & 139628 Guatemala & Alta Verapaz & $\cdots$ & $15018^{\prime} 00 " \mathrm{~N}$ & 89037'00" & & 50 Tenerorio $\mathrm{P}$. & 14433 & 7/12/88 \\
\hline Croton billbergianus Müell.Arg. & & мо & $* * *$ & Guatemala & Izabal & --- & $15042^{\prime} 00 " \mathrm{~N}$ & 88038'00" & -- & N.T.Marshall et al. 370 & & $3 / 12 / 88$ \\
\hline Croton billbergianus Müell.Arg. & & мо & $* * * *$ & Honduras & Copán & $\ldots$ & $14055^{\circ} 00^{\prime \prime} \mathrm{N}$ & $88055^{\prime} 00^{\prime \prime}$ & & 702 A. Molina 30618 & & $1 / 22 / 75$ \\
\hline
\end{tabular}




\begin{tabular}{|c|c|c|c|c|c|c|c|c|c|c|c|c|c|}
\hline \multirow{2}{*}{$\begin{array}{l}\text { Espécie } \\
\text { N.científico }\end{array}$} & \multirow[b]{2}{*}{ N. vulgar } & \multicolumn{3}{|l|}{ Herbário } & \multicolumn{3}{|l|}{ Localidade } & \multirow[b]{2}{*}{ 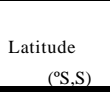 } & \multirow[b]{2}{*}{$\begin{array}{r}\text { Longitude } \\
\left({ }^{\circ} \mathrm{S}, \mathrm{W}\right) \\
\end{array}$} & \multirow[b]{2}{*}{ Altitude } & \multicolumn{2}{|l|}{ COLETOR } & \multirow[b]{2}{*}{ Data } \\
\hline & & Sigla & Registro & & País & Estado & Município & & & & Nome/número & & \\
\hline Croton billbergianus Müell.Arg. & --- & $\mathrm{R}$ & & 222230 & Honduras & --- & - & --- & --- & --- & J.R.Wiley & 7 & $00 / 08 / 193^{\prime}$ \\
\hline Croton billbergianus Müell.Arg. & & мо & $* * *$ & & Panamá & Área do Canal & -- & $09010^{\circ} 00^{\prime \prime} \mathrm{N}$ & $79045^{\prime} 00^{\prime \prime}$ & -. & T. Croat 14815 & & $5 / 27 / 7$ \\
\hline Crotonbillbergianus Müell.Arg. & & мо & $* * *$ & & Panamá & Área do Canal & -- & $09010^{\prime} 00^{\prime \prime} \mathrm{N}$ & $79045^{\prime} 00^{\prime \prime}$ & -. & J.S.Miller 1030 & & 8/6/8: \\
\hline Croton billbergianus Müell.Arg. & & MO & $* * *$ & & Panamá & Área do Canal & -. & $09010^{\circ} 00^{\prime \prime} \mathrm{N}$ & $79045^{\prime} 00^{\prime \prime}$ & $\ldots$ & A. Gentry 1954 & & $9 / 28 / 7$ \\
\hline Croton billbergianus Müell.Arg. & & мо & $* * *$ & & Panamá & Área do Canal & -. & $09010^{\prime} 00^{\prime \prime} \mathrm{N}$ & $79045^{\prime} 00^{\prime \prime}$ & $\ldots$ & J.A. Duke 11716 & & $1 / 1 / 6$ \\
\hline Crotonbillbergianus Müell.Arg. & & мо & $* * *$ & & Panamá & Área do Canal & -_- & $09010^{\circ} 00^{\prime \prime} \mathrm{N}$ & 79045'00" & ... & J.S.Miller 1032 & & 8/6/8: \\
\hline Croton billbergianus Müell.Arg. & & MO & $* * *$ & & Panamá & Área do Canal & - & $0900956 " \mathrm{~N}$ & 79049'46" & $\cdots$ & T.B. Croat 6113 & & 8/6/6: \\
\hline Croton billbergianus Müell.Arg. & & мо & $* * *$ & & Panamá & Darién & -. & $08013^{\prime} 00^{\prime \prime} \mathrm{N}$ & $77054^{\prime} 00^{\prime \prime}$ & & 00 Gentry et al.16957 & & $7 / 23 / 71$ \\
\hline Croton billbergianus Müell.Arg. & & мо & $* * *$ & & Panamá & San Blas & -- & $0803959 " \mathrm{~N}$ & 77024'59" & & 25 S.Knapp et al. 4671 & & 4/17/8: \\
\hline Crotonbillbergianus Müell.Arg. & & мо & $* * *$ & & Panamá & San Blas & - & $08039 \cdot 59 " \mathrm{~N}$ & 77024'59" & & 25 S.Knapp et al. 4667 & & 4/17/8: \\
\hline Crotonbillbergianus Müell.Arg. & & мо & $* * *$ & & Panamá & San Blas & -- & $09019^{\prime} 00^{\prime \prime} \mathrm{N}$ & $78055^{\prime} 00^{\prime \prime}$ & & 50 Greg de Nevers 5806 & & $5 / 24 / 8:$ \\
\hline Croton billbergianus Müell.Arg. & & мо & $* * *$ & & Panamá & Veraguas & -. & $10008^{\prime} 48^{\prime \prime} \mathrm{N}$ & $81002^{\prime} 00^{\prime \prime}$ & -.. & G.McPherson 11383 & & 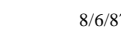 \\
\hline Crotonfloribundus Spreng. & -.. & SPF & & 140229 & Brasil & Bahia & - & $15017^{\prime} 00 " \mathrm{~s}$ & $39001^{\prime} 00^{\prime \prime}$ & -.. & & & st \\
\hline Crotonfloribundus Spreng. & --. & $\mathrm{RB}$ & & 135141 & Brasil & Bahia & -- & $09037^{\prime} 30 " \mathrm{~s}$ & $3803600 "$ & -. & & & $\mathrm{st}$ \\
\hline Croton floribundus Spreng. & -.- & $\mathrm{RB}$ & & 102717 & Brasil & Ceará & Viçosa & -.. & -- & -- & -- & 2755 & $5 / 10 / 7$ \\
\hline Crotonfloribundus Spreng. & -.. & $\mathrm{RB}$ & & 100609 & Brasil & Ceará & -- & -.. & -- & -.. & "Lofgren & 171 & $00 / 00 / 1911$ \\
\hline Crotonfloribundus Spreng. & -.- & $\mathrm{SP}$ & & 42312 & Brasil & Goiás & Brasilia-DF & -.. & -- & -.. & E.D.N. de Andrade & 4 & $2 / 16 / 41$ \\
\hline Crotonfloribundus Spreng. & Capixingui & SP & & 540 & Brasil & Maranhão & Loreto & $07013^{\prime} 00^{\prime \prime} \mathrm{S}$ & $45006^{\prime} 00^{\prime \prime}$ & & $50 \mathrm{C} .{ }^{\circ} \mathrm{Kuhlman}$ & 44 & $00 / 12 / 1911$ \\
\hline Croton floribundus Spreng. & Capiringui de lika & $\mathrm{RB}$ & & 99468 & Brasil & Maranhão & Loreto & $07013^{\prime} 00 " \mathrm{~s}$ & $45006^{\prime} 00^{\prime \prime}$ & & $50^{\circ} \mathrm{Vicchi}$ & sn & $00 / 11 / 01$ \\
\hline Crotonfloribundus Spreng. & --- & MG & & 120996 & Brasil & Maranhão & São Luís & $04000^{\circ} 00^{\prime \prime} \mathrm{s}$ & $44056^{\circ} 00^{\prime \prime}$ & ... & Brenha-Macárico & $50 \mathrm{a}$ & $4 / 1 / 8$ \\
\hline Crotonfloribundus Spreng. & -.- & $\mathrm{SP}$ & & 332878 & Brasil & Mato Grasso do $\mathrm{S}$ & 1 Batagrassu & $21045^{\prime} 15^{\prime \prime} \mathrm{S}$ & $5202621 "$ & -.. & "Amaral Jr. Et al. & 603 & 10/15/9; \\
\hline Crotonfloribundus Spreng. & --. & воте & & 21831 & Brasil & Mato Grosso do $\mathrm{S}$ & 1 Bataguassu & $25045^{\prime} 15^{\prime \prime} \mathrm{S}$ & $5202621^{\prime \prime}$ & -- & A.Amaral Jr. Et al & 204 & 00/08/209' \\
\hline Croton floribundus Spreng. & Sangue-drago & $\mathrm{SP}$ & & 263059 & Brasil & Minas Gerais & -- & -.. & -- & -- & P.L.Krieger & 204 & 12/17/9: \\
\hline Crotonfloribundus Spreng. & Capixingui & $\mathrm{RB}$ & & 99347 & Brasil & Minas Gerais & -. & -.- & -- & -.. & L.Silva & sn & 11/20/0: \\
\hline Crotonfloribundus Spreng. & -.- & $\mathrm{RB}$ & & 158209 & Brasil & Minas Gerais & Belo horizonte & -.- & -- & & 00 H.S.Irwin & 19789 & 2/10/6 \\
\hline Croton floribundus Spreng. & --. & $\mathrm{RB}$ & & 54008 & Brasil & Minas Gerais & Caeté & -.. & -- & & 00 P-B-Cuezzo & 4000 & 12/28/4i \\
\hline Croton floribundus Spreng. & --- & $\mathrm{RB}$ & & 100601 & Brasil & Minas Gerais & Caldas & -.- & --- & -.. & Regnell & ii- 242 & st \\
\hline Croton floribundus Spreng. & --- & SP & & 245740 & Brasil & Minas Gerais & Carangola & 20044'00"S & $42004^{\prime} 00^{\prime \prime}$ & $\cdots$ & L.S.Leoni & sn & 12/6/8: \\
\hline Crotonfloribundus Spreng. & -.- & $\mathrm{SP}$ & & 348431 & Brasil & Minas Gerais & Descoberto & -.- & -- & -.. & R.M.Castro & 742 & $1 / 24 / 0$ \\
\hline Croton floribundus Spreng. & --- & $\mathrm{SP}$ & & 348442 & Brasil & Minas Gerais & Descoberto & -.. & -- & -.. & L.D.Meireles et al. & sn & 2/2/0: \\
\hline Croton floribundus Spreng. & --- & $\mathrm{RB}$ & & 158991 & Brasil & Minas Gerais & Lagoa & -.- & --- & -.. & M.C.Weyland & 834 & 11/19/8: \\
\hline Croton floribundus Spreng. & --- & $\mathrm{RB}$ & & 158992 & Brasil & Minas Gerais & Lagoa & -- & -- & $\cdots$ & M.C.Weyland & 845 & $1 / 4 / 8$ \\
\hline Crotonfloribundus Spreng. & -.- & $\mathrm{SP}$ & & 183474 & Brasil & Minas Gerais & Lagoa Douroda & -.- & -- & -.. & J.R.Pirani et al. & 309 & 12/16/8: \\
\hline Croton floribundus Spreng. & -.- & UEC & & 22675 & Brasil & Minas Gerais & Lavras & -.. & -- & -- & H.F.Leitão et al. & 11864 & 12/9/81 \\
\hline Croton floribundus Spreng. & Capixingui & UEC & & 35630 & Brasil & Minas Gerais & Lavras & -.. & --. & $\ldots$ & M.C.Weyland V. & 77 & 11/28/8: \\
\hline Croton floribundus Spreng. & Capixingui & $\mathrm{RB}$ & & 190071 & Brasil & Minas Gerais & Lima Duarte & -- & -- & -- & V.C.deAlmeida & 122 & 1/1/9: \\
\hline Croton floribundus Spreng. & -.- & UEC & & 91121 & Brasil & Minas Gerais & Monte Belo & -.. & -- & -.. & S.B.deSouza & 1152 & 4/22/9. \\
\hline Croton floribundus Spreng. & -.- & UEC & sn & & Brasil & Minas Gerais & Monte Belo & -.- & -- & -- & M.C.Weyland V. & 845 & $1 / 4 / 8$ \\
\hline Croton floribundus Spreng. & Capiocingui & UEC & & 45794 & Brasil & Minas Gerais & Monte Belo & -- & -- & -. & M.C.Weyland V. & 77 & 11/28/8: \\
\hline Croton floribundus Spreng. & $\ldots$ & $\mathrm{SP}$ & & 292076 & Brasil & Minas Gerais & Ouro Branco & $20030^{\circ} 45^{\prime \prime} \mathrm{S}$ & 43039'08" & 110 & 00 V.C.Souza et al. & 946 & 3/8/9: \\
\hline
\end{tabular}




\begin{tabular}{|c|c|c|c|c|c|c|c|c|c|c|c|c|}
\hline \multirow{2}{*}{$\begin{array}{l}\text { Espécie } \\
\text { N.científico }\end{array}$} & \multirow[b]{2}{*}{ N. vulgar } & \multicolumn{2}{|c|}{ Herbário } & \multicolumn{2}{|c|}{ Localidade } & \multirow[b]{2}{*}{ Município } & \multirow[b]{2}{*}{ 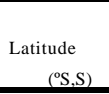 } & \multirow[b]{2}{*}{$\begin{array}{r}\text { Longitude } \\
\left({ }^{\circ} \mathrm{S}, \mathrm{W}\right) \\
\end{array}$} & \multirow[b]{2}{*}{$\begin{array}{r}\text { Altitude } \\
\text { (manm) }\end{array}$} & \multicolumn{2}{|l|}{ COLETOR } & \\
\hline & & Sigla & Registro & País & Estado & & & & & Nome/número & & \\
\hline Croton floribundus Spreng. & -- & $\mathrm{RB}$ & & 99797 Brasil & Minas Gerais & Ouro Preto & --- & --- & --- & W.Bello & 412 & $00 / 00 / 1888$ \\
\hline Croton floribundus Spreng. & -- & UEC & & 26166 Brasil & Minas Gerais & Poços de Caldas & $21050^{\prime 20 " \mathrm{~s}}$ & 46033'53" & -.- & F.R.Martins et al. & 1619 & $12 / 3 / 81$ \\
\hline Croton floribundus Spreng. & -- & UEC & & 23456 Brasil & Minas Gerais & Poços de Caldas & $21050^{\prime 20} \mathrm{\prime S}$ & $46033^{\prime} 53^{\prime \prime}$ & -- & L."F. Mathes et al. & 671 & $1 / 12 / 81$ \\
\hline Croton floribundus Spreng. & Capixinguí & SPF & & 92582 Brasil & Minas Gerais & Tiradentes & $21005^{\prime} 14{ }^{\prime \prime S}$ & $44010^{\prime} 30^{\prime \prime}$ & & 80 Giuletti A.M. & 13658 & $1 / 16 / 94$ \\
\hline Croton floribundus Spreng. & -- & SP & & 76242 Brasil & Minas Gerais & Uberlandia & $\cdots$ & -- & --- & G.M.Araújo & 677 & $11 / 2 / 89$ \\
\hline Croton floribundus Spreng. & _- & UEC & & 59556 Brasil & Minas Gerais & Uberlândia & ... & ... & .-. & G.M.deAraújo & 709 & $11 / 2 / 86$ \\
\hline Croton floribundus Spreng. & - & $\mathrm{RB}$ & & 58694 Brasil & Minas Gerais & Viçosa & -.- & -- & -- & H.S.Irwin & 2151 & $11 / 26 / 58$ \\
\hline Croton floribundus Spreng. & -- & $\mathrm{RB}$ & & 00155 Brasil & Minas Gerais & Viçosa & -.. & -.- & -.- & H.S.Irwin & 2274 & $2 / 12 / 58$ \\
\hline Croton floribundus Spreng. & Marmeleiro & SP & & 83010 Brasil & Paraíba & Aréia & $\cdots$ & -- & -- & J.M.Vasconcellos & 15200 & $4 / 13 / 47$ \\
\hline Croton floribundus Spreng. & -- & $\mathrm{RB}$ & & 68463 Brasil & Paraná & Arapoti & -.- & --- & -.- & J.Augusto & sn & $12 / 14 / 88$ \\
\hline Croton floribundus Spreng. & -- & SP & & 27581 Brasil & Paraná & Assaí & -.. & -- & -- & L.R.M.Souza et al. & $\mathrm{sn}$ & 12/9/97 \\
\hline Croton floribundus Spreng. & -- & SP & & 35147 Brasil & Paraná & Bela Vista do Paraíso & -.. & -.- & -.- & E.M.Francisco et al. & sn & 10/7/98 \\
\hline Croton floribundus Spreng. & -- & UEC & & 09121 Brasil & Paraná & Bela Vista do Paraíso & -.. & -- & --. & E.M.Francisco et al. & sn & 10/7/98 \\
\hline Croton floribundus Spreng. & -- & $\mathrm{RB}$ & & 89367 Brasil & Paraná & California & -.. & -- & -- & J.C.Lindeman et al. & 3262 & $11 / 15 / 66$ \\
\hline Croton floribundus Spreng. & Capixingui & SP & & 28775 Brasil & Paraná & Cambe & -.. & -- & -- & V.F.Kinupp et al. & 709 & 11/7/97 \\
\hline Croton floribundus Spreng. & & SPSF & & 23460 Brasil & Paraná & Guairaçá & & & & V.F. Kinupp & 33 & $11 / 4 / 96$ \\
\hline Croton floribundus Spreng. & -- & SP & & 27583 Brasil & Paraná & Iboporã & -.. & -- & --. & aP.R.Moura & 139 & 10/31/97 \\
\hline Croton floribundus Spreng. & -- & $\mathrm{RB}$ & & 58253 Brasil & Paraná & Jaguariaiva & $240177^{\prime} 00^{\prime S} \mathrm{~S}$ & $49017^{\prime} 00^{\prime \prime}$ & & 40 L.B.Smith et al. & 14644 & $1 / 17765$ \\
\hline Croton floribundus Spreng. & -- & SPF & & 47470 Brasil & Paraná & Londrina & -.. & -- & -- & Barros A. et al & $\mathrm{S} / \mathrm{N}$ & $10 / 22 / 98$ \\
\hline Croton floribundus Spreng. & -_ & SP & & 32498 Brasil & Paraná & Londrina & -.- & --- & -.- & L.H.Soarez et al. & 152 & $12 / 1 / 88$ \\
\hline Croton floribundus Spreng. & -- & SP & & 32494 Brasil & Paraná & Londrina & -.. & -- & --. & L.H.Soarez et al. & 171 & $11 / 23 / 88$ \\
\hline Croton floribundus Spreng. & -- & SP & & 32493 Brasil & Paraná & Londrina & -.. & -- & -- & L.H.Soarez et al. & 157 & $1 / 14 / 89$ \\
\hline Croton floribundus Spreng. & -- & UEC & & 46584 Brasil & Paraná & Londrina & -.. & -- & -- & F.E. Paro & 39 & $10 / 23 / 86$ \\
\hline Croton floribundus Spreng. & -_ & UEC & & 46567 Brasil & Paraná & Londrina & -.- & --- & -.- & J.L.Orlandeli & sn & $11 / 29 / 85$ \\
\hline Croton floribundus Spreng. & Capixingui & UEC & & 19182 Brasil & Paraná & Londrina & -.. & --. & --. & D. Estevan et al. & 137 & $11 / 10 / 99$ \\
\hline Croton floribundus Spreng. & -- & UEC & & 46576 Brasil & Paraná & Londrina & -.. & -- & -- & M.I. J.Neves et al. & sn & $10 / 31 / 84$ \\
\hline Croton floribundus Spreng. & -- & UEC & & 57162 Brasil & Paraná & Luis Teixeira Mendes & -.. & -.- & $\ldots$ & B.E.Dutra et al. & 142 & $11 / 11 / 83$ \\
\hline Croton floribundus Spreng. & -- & $\mathrm{RB}$ & & 94288 Brasil & Pernambuco & Petrolina & --- & -- & -- & P.Carauta et al. & 991 & $1 / 22 / 70$ \\
\hline Croton floribundus Spreng. & -- & UEC & & 15331 Brasil & Pernambuco & São Bened.d'Sul & -.. & --. & --. & "M.Miranda & 1152 & $1 / 11 / 94$ \\
\hline Croton floribundus Spreng. & -- & UEC & & 40651 Brasil & Rio de Janeiro & Barra da Tijuca & $22057^{\prime} 30 " \mathrm{~s}$ & $45014^{\prime} 30^{\prime \prime}$ & & 50 G.L.Webster et al. & 25431 & $10 / 27 / 84$ \\
\hline Croton floribundus Spreng. & -- & $\mathrm{RB}$ & & 89977 Brasil & Rio de Janeiro & Nova Friburgo & -.. & $\ldots$ & $\ldots$ & aSouza et al. & sn & 7/27/96 \\
\hline Croton floribundus Spreng. & -- & SP & & 02893 Brasil & Rio de Janeiro & Rezende & --- & -- & -- & J.Mattos & 15200 & $11 / 24 / 67$ \\
\hline Croton floribundus Spreng. & -- & $\mathrm{RB}$ & & 59329 Brasil & Rio de Janeiro & Rio de Janeiro & -.- & --. & --. & "Souza & sn & $4 / 4 / 86$ \\
\hline Croton floribundus Spreng. & -- & $\mathrm{RB}$ & & 62358 Brasil & Rio de Janeiro & Rio de Janeiro & -.- & -- & -- & M..Alvés et al. & 109 & $3 / 23 / 88$ \\
\hline Croton floribundus Spreng. & -- & $\mathrm{RB}$ & & 68837 Brasil & Rio de Janeiro & Rio de Janeiro & -.. & -.- & $\ldots$ & aSouza & sn & 00/01/1989 \\
\hline Croton floribundus Spreng. & -- & $\mathrm{RB}$ & & 69455 Brasil & Rio de Janeiro & Rio de Janeiro & -- & -- & -- & "Souza & sn & 00/05/1987 \\
\hline Croton floribundus Spreng. & -- & $\mathrm{RB}$ & & 77667 Brasil & Rio de Janeiro & Rio de Janeiro & -.- & --. & --. & "Souza et al. & 1794 & 10/6/87 \\
\hline Croton floribundus Spreng. & -- & $\mathrm{RB}$ & & 89466 Brasil & Rio de Janeiro & Rio de Janeiro & -.- & -- & -- & "asouza & sn & 9/30/85 \\
\hline Croton floribundus Spreng. & -- & $\mathrm{RB}$ & & 00535 Brasil & Rio de Janeiro & Rio de Janeiro & -.. & -.- & -- & Meyer & sn & $4 / 28 / 14$ \\
\hline Croton floribundus Spreng. & -. & $\mathrm{RB}$ & & 26048 Brasil & Rio de Janeiro & Rio de Janeiro & -.. & $\ldots$ & $\ldots$ & Schwake & $\mathrm{sn}$ & $02 / 11 / 1883$ \\
\hline
\end{tabular}




\begin{tabular}{|c|c|c|c|c|c|c|c|c|c|c|c|c|}
\hline \multirow{2}{*}{$\begin{array}{l}\text { Espécie } \\
\text { N.científico }\end{array}$} & \multirow[b]{2}{*}{ N. vulgar } & \multicolumn{2}{|l|}{ Herbário } & \multicolumn{2}{|l|}{ Localidade } & \multirow[b]{2}{*}{ Município } & \multirow[b]{2}{*}{ 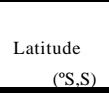 } & \multirow[b]{2}{*}{$\begin{array}{r}\text { Longitude } \\
\left({ }^{\circ} \mathrm{S}, \mathrm{W}\right) \\
\end{array}$} & \multirow[b]{2}{*}{$\begin{array}{r}\text { Altitude } \\
(\mathrm{manm})\end{array}$} & \multicolumn{2}{|l|}{$\begin{array}{l}\text { COLETOR } \\
\text { Nome/número }\end{array}$} & \multirow[b]{2}{*}{ ata } \\
\hline & & Sigla & Registro & País & Estado & & & & & Nome/número & & \\
\hline Croton floribundus Spreng. & $\cdots$ & RB & 169454 & 4 Brasil & Rio de Janeiro & Santa Teresa & $\cdots$ & $\ldots$ & $\cdots$ & ${ }^{\text {aCCastellanos }}$ & 23206 & $5 / 13 / 6$ \\
\hline Crotonfloribundus Spreng. & -.. & $\mathrm{RB}$ & 168576 & 6 Brasil & Rio de Janeiro & Teresópolis & -.- & -.- & -.- & L.Emygdio & 5365 & $1 / 15 / 8$ \\
\hline Croton floribundus Spreng. & -.- & $\mathrm{RB}$ & 169332 & 2 Brasil & Rio de Janeiro & Teresópolis & -- & -.- & -- & ${ }^{\text {aSouza }}$ & $\mathrm{sn}$ & $10 / 25 / 8$ \\
\hline Croton floribundus Spreng. & -.. & $\mathrm{RB}$ & 189976 & 6 Brasil & Rio de Janeiro & Teresópolis & -.- & -.. & -.- & ${ }^{\text {aSouza }}$ & $\mathrm{sn}$ & $10 / 25 / 8$ \\
\hline Croton floribundus Spreng. & -.- & $\mathrm{RB}$ & 194092 & 2 Brasil & Rio de Janeiro & Teresópolis & -.- & -.. & -.- & L.a.F.deCavalho & 511 & $5 / 29 / 7$ \\
\hline Croton floribundus Spreng. & ... & $\mathrm{RB}$ & 201017 & 7 Brasil & Rio de Janeiro & Teresópolis & ... & ... & ... & U.S.N.Maia & $\mathrm{sn}$ & $00 / 05 / 200$ \\
\hline Croton floribundus Spreng. & -.- & $\mathrm{RB}$ & 196916 & 6 Brasil & Rio de Janeiro & Teresópolis & $22030^{\circ} 00^{\prime \prime} \mathrm{S}$ & $43000^{\circ} 00^{\prime \prime}$ & & 00 G.L.Webster & 25863 & $11 / 28 / 8$ \\
\hline Croton floribundus Spreng. & -.. & $\mathrm{RB}$ & 99266 & 6 Brasil & Rio de Janeiro & Teresópolis & -.- & -.. & -.- & J.deSaldanha & $\mathrm{sn}$ & $07 / 01 / 188$ \\
\hline Crotonfloribundus Spreng. & --- & $\mathrm{RB}$ & 99662 & 2 Brasil & Rio de Janeiro & Teresópolis & -.- &.-- & -.- & J.deSaldanha & $\mathrm{sn}$ & $07 / 01 / 188$ \\
\hline Crotonfloribundus Spreng. & -..- & $\mathrm{RB}$ & 99253 & 3 Brasil & Rio de Janeiro & Teresópolis & -- & -.. & -.- & H.P.Velloso & $\mathrm{sn}$ & $12 / 21 / 4$ \\
\hline Croton floribundus Spreng. & -.- & ESA & 37131 & 1 Brasil & São Paulo & -- & -.- & -.- & -. & -.- & -.- & $08 / 00 / 199$ \\
\hline Croton floribundus Spreng. & -.. & ESA & 33274 & 4 Brasil & São Paulo & -- & -.- & -.. & -.- & -.- & -.. & $\mathrm{s}$ \\
\hline Croton floribundus Spreng. & -.- & ESA & 23146 & 6 Brasil & São Paulo & - & -.- & -.- & -.- & -.- & -.. & $10 / 11 / 9$ \\
\hline Crotonfloribundus Spreng. & -.- & ESA & 70767 & 7 Brasil & São Paulo & -- & -.- & -.- & -.- & -.- & -.. & $15 / 04 / 199$ \\
\hline Croton floribundus Spreng. & -.- & ESA & 10110 & 0 Brasil & São Paulo & -- & -.- & -.- & -. & -. & -.- & $3 / 10 / 8$ \\
\hline Crotonfloribundus Spreng. & -.. & ESA & 10103 & 3 Brasil & São Paulo & - & -.- & -.- & -.- & -.. & -.. & $31 / 10 / 198$ \\
\hline Croton floribundus Spreng. & Capixingui & SP & 2428 & 8 Brasil & São Paulo & - & -.- & -.- & -.- & "V.Emelen & 12 & 9/25/1 \\
\hline Crotonfloribundus Spreng. & -.- & SP & 343209 & 9 Brasil & São Paulo & $=343214$ & -.- & -.- & -.- & D.C.Cavalcanti & 278 & $\mathrm{~s}$ \\
\hline Croton floribundus Spreng. & -.- & SP & 204090 & 0 Brasil & São Paulo & $=204092$ & -.- & -.- & -. & -. & $\mathrm{sn}$ & \\
\hline Croton floribundus Spreng. & -.. & $\mathrm{SP}$ & 296902 & 2 Brasil & São Paulo & Abatuba & -.- & -.- & -.- & H.F.Leitão Fo. & 34840 & $2 / 16 / 9$ \\
\hline Croton floribundus Spreng. & -.- & SP & 330822 & 2 Brasil & São Paulo & Agudos & -.- & -.- & -. & P.F.Assis et al. & 480 & $11 / 4 / 9$ \\
\hline Croton floribundus Spreng. & -.. & $\mathrm{SP}$ & 308502 & 2 Brasil & São Paulo & Agudos & -.- & -.- & -.- & S.R.Christianini & 334 & 9/26/9 \\
\hline Croton floribundus Spreng. & -.- & SP & 330823 & 3 Brasil & São Paulo & Agudos & -.- & -.- & -.- & P.F.Assis et al. & 478 & $11 / 14 / 9$ \\
\hline Crotonfloribundus Spreng. & -.- & воте & 1829 & 9 Brasil & São Paulo & Agudos & -.- & -.- & -.- & P.F.Assis et al. & 478 & $00 / 08 / 212$ \\
\hline Croton floribundus Spreng. & -.- & воти & 1821 & 1 Brasil & São Paulo & Agudos & -.- & -.. & -.- & P.F.Assis et al. & $\mathrm{sn}$ & $00 / 08 / 213$ \\
\hline Croton floribundus Spreng. & --- & воте & 1816 & 6 Brasil & São Paulo & Agudos & -- & --- & -.- & P.F.Assis et al. & 339 & $00 / 08 / 213$ \\
\hline Crotonfloribundus Spreng. & -.- & НRСB & 15452 & 2 Brasil & São Paulo & Analândia & -.- & -.- & -.- & R.J.Almeida & $\mathrm{sn}$ & $10 / 26 / 9$ \\
\hline Croton floribundus Spreng. & -.. & UEC & 22065 & 5 Brasil & São Paulo & Anhembi & -.- & -.. & -.- & C.T.de Asumpçã̃ & 7507 & $00 / 10 / 197$ \\
\hline Croton floribundus Spreng. & Tapichingui & НRСв & 1646 & 6 Brasil & São Paulo & Anhenbi & -.- & -.. & -.- & -.- & $\mathrm{sn}$ & $11 / 17 / 8$ \\
\hline Croton floribundus Spreng. & --- & HRCB & 2309 & 9 Brasil & São Paulo & Anhenbi & -- & --- & -.- & O.Cesar et al. & $\mathrm{sn}$ & $11 / 16 / 8$ \\
\hline Crotonfloribundus Spreng. & -.- & НRСB & 2406 & 6 Brasil & São Paulo & Anhenbi & -.. & -.- & -.- & O.Cesar et al. & $\mathrm{sn}$ & $1 / 15 / 8$ \\
\hline Croton floribundus Spreng. & -.- & HRCB & 3690 & 0 Brasil & São Paulo & Anhenbi & -.- & -.- & -. & O.Cesar et al. & $\mathrm{sn}$ & $11 / 21 / 8$ \\
\hline Croton floribundus Spreng. & Capechingui & HRСв & 9022 & 2 Brasil & São Paulo & Anhenbi & -.. & -.. & -.- & C.T.deAssumpção & 7507 & $10 / 31 / 7$ \\
\hline Crotonfloribundus Spreng. & --- & UEC & 111064 & 4 Brasil & São Paulo & Areão & -.- & --- & -.- & E.L.M.Catharino & 196 & $10 / 20 / 8$ \\
\hline Crotonfloribundus Spreng. & -.- & UEC & 82007 & 7 Brasil & São Paulo & Assis & -.. & -.- & -.- & G.Durigan & 31708 & $4 / 15 / 9$ \\
\hline Croton floribundus Spreng. & -.- & SP & 298796 & 6 Brasil & São Paulo & Atibaia & -.- & -.- & -.. & R.Behr & $\mathrm{sn}$ & $10 / 27 / 8$ \\
\hline Croton floribundus Spreng. & -.- & UEC & 55694 & 4 Brasil & São Paulo & Atibaia & -.. & -.. & -.. & J.M.M.Neto et al. & 21361 & $11 / 16 / 8$ \\
\hline Crotonfloribundus Spreng. & $\ldots$ & $\mathrm{SP}$ & 345918 & 8 Brasil & São Paulo & Avaí & $22015^{\circ} 00^{\prime \prime S}$ & $49021^{\prime} 00^{\prime \prime}$ & $\ldots$ & aP.Bertocini & 1073 & $11 / 8 / 9$ \\
\hline
\end{tabular}




\begin{tabular}{|c|c|c|c|c|c|c|c|c|c|c|c|c|}
\hline \multirow{2}{*}{$\begin{array}{l}\text { Espécie } \\
\text { N.científico }\end{array}$} & \multirow[b]{2}{*}{ N. vulgar } & \multicolumn{2}{|l|}{ Herbário } & \multicolumn{2}{|c|}{ Localidade } & \multirow[b]{2}{*}{ Município } & \multirow[b]{2}{*}{$\begin{array}{l}\text { Latitude } \\
\left({ }^{\circ} \mathrm{S}, \mathrm{S}\right)\end{array}$} & \multirow[b]{2}{*}{$\begin{array}{r}\text { Longitude } \\
\left({ }^{\circ} \mathrm{S}, \mathrm{W}\right)\end{array}$} & \multirow[b]{2}{*}{ Altitude } & \multicolumn{3}{|l|}{ COLETOR } \\
\hline & & Sigla & Registro & País & Estado & & & & & e Nome/número & & \\
\hline Crotonfloribundus Spreng. & $\ldots$ & SPF & 114855 & Brasil & São Paulo & Avaré & 23011 1'07"S & $48057^{\prime} 53 "$ & & 610 Souza V.C. & 10393 & $1 / 24 / 91$ \\
\hline Crotonfloribundus Spreng. & ... & $\mathrm{SP}$ & 297586 & 6 Brasil & São Paulo & Avaré & $2301106 " \mathrm{~s}$ & $4805753 "$ & & 610 V.C.Souza et al. & 10383 & 1/24/91 \\
\hline Croton floribundus Spreng. & --- & $\mathrm{RB}$ & 158326 & Brasil & São Paulo & Bagatuba & -.. & --- & -.. & E.Emmerich et al. & 3421 & 12/20/6 \\
\hline Croton floribundus Spreng. & --- & $\mathrm{SP}$ & 344413 & Brasil & São Paulo & Bauru & $\ldots$ & -- & -.. & M.H.PPinheiro & 240 & 12/24/91 \\
\hline Crotonfloribundus Spreng. & --- & $\mathrm{SP}$ & 327572 & Brasil & São Paulo & Bauru & --- & --- & $\cdots$ & M.H.'Pinheiro & 177 & $10 / 31 / 91$ \\
\hline Crotonfloribundus Spreng. & -.- & UEC & 29304 & 4 Brasil & São Paulo & Bauru & -.- & --- & -.. & Cavassan & 105 & $11 / 4 / 81$ \\
\hline Crotonfloribundus Spreng. & --- & HRCB & 31929 & Brasil & São Paulo & Bauru & -- & -- & $\cdots$ & M.H.'Pinheiro & 240 & 12/24/91 \\
\hline Crotonfloribundus Spreng. & 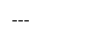 & НRСB & 31966 & Brasil & São Paulo & Bauru & $\ldots$ & -- & -.. & М.H.'Pinheiro & 177 & 10/31/91 \\
\hline Crotonfloribundus Spreng. & ..- & НRCB & 1709 & Brasil & São Paulo & Bauru & ... & ..- & ... & Cavassan & 9 & $00 / 10 / 0$ \\
\hline Croton floribundus Spreng. & --- & UEC & 98273 & 3 Brasil & São Paulo & Bom Sucesso de Itararé & $24017577^{\prime S}$ & $49012^{2} 54^{\prime \prime}$ & -- & F.Chung et al. & 227 & $12 / 19 / 0$ \\
\hline Croton floribundus Spreng. & Capixingui & НRСB & 9600 & Brasil & São Paulo & Botucatu & $23045^{\prime} 00^{\prime \prime S}$ & $48025^{\prime} 00^{\prime \prime}$ & & 550 J.L.C.Grabiel & sn & $12 / 10 / 8^{\circ}$ \\
\hline Crotonfloribundus Spreng. & Cupixingui & воте & 5501 & Brasil & São Paulo & Botucatu & $23045^{\prime} 00^{\prime \prime} \mathrm{s}$ & $48025^{\prime} 00^{\prime \prime}$ & & 550 G.Zachi & sn & $00 / 08 / 211$ \\
\hline Crotonfloribundus Spreng. & Capi-xingui & вотU & 7820 & Brasil & São Paulo & Botucatu & $23045^{\prime} 00^{\prime \prime S}$ & $48025^{\prime} 00^{\prime \prime}$ & & 550 I.C.Izatto & 12 & 00/08/211: \\
\hline Croton floribundus Spreng. & --- & воте & 2005 & Brasil & São Paulo & Botucatu & $23045^{\circ} 00^{\prime \prime} \mathrm{s}$ & $48025^{\prime} 00^{\prime \prime}$ & & 550 J.Manetti F. & 18 & 00/08/211: \\
\hline Crotonfloribundus Spreng. & --- & UEC & 84242 & 2 Brasil & São Paulo & Brotas & $\ldots$ & -- & ... & L.C.Bernacci & 35048 & $5 / 6 / 9$ \\
\hline Croton floribundus Spreng. & --- & UEC & sn & Brasil & São Paulo & Buri & $\ldots$ & -- & -.. & E.V. Franceschinelli & 17123 & 4/5/8: \\
\hline Croton floribundus Spreng. & Capixingui & $\mathrm{SP}$ & 1369 & Brasil & São Paulo & Butantã & -- & -- & -- & F.C.Hoehne & sn & 1/25/1: \\
\hline Croton floribundus Spreng. & --- & UEC & 4696 & Brasil & São Paulo & Campinas & $22050^{\prime} 13 " \mathrm{~S}$ & $46055^{\prime} 58 "$ & -- & "a.Gabrielli et al. & 8849 & 10/4/7: \\
\hline Crotonfloribundus Spreng. & --- & $\mathrm{SP}$ & 40757 & 7 Brasil & São Paulo & Campinas & $22050^{\prime} 13 " \mathrm{~S}$ & $46055^{\prime} 58^{\prime \prime}$ & ... & C.Morão et al. & sn & $11 / 6 / 3:$ \\
\hline Croton floribundus Spreng. & --- & $\mathrm{SP}$ & 35584 & 4 Brasil & São Paulo & Campinas & $22050^{\prime} 13 " \mathrm{~S}$ & $46055^{\prime} 58^{\prime \prime}$ & -.. & E.J.Hambleton & 4 & $00 / 04 / 193$ \\
\hline Croton floribundus Spreng. & --- & UEC & 108510 & 0 Brasil & São Paulo & Campinas & $22049^{\prime} 45^{\prime \prime S}$ & $4700633 "$ & ... & M.T.G-Guaratini et al. & 242 & 10/19/91 \\
\hline Croton floribundus Spreng. & Pau caxeta & UEC & 97792 & 2 Brasil & São Paulo & Campinas & $22050^{\prime} 13 " \mathrm{~S}$ & $46055^{\prime} 58 "$ & -.. & K.Santos & 107 & 10/18/91 \\
\hline Croton floribundus Spreng. & --- & UEC & 97793 & 3 Brasil & São Paulo & Campinas & $22050^{\prime} 13 " \mathrm{~S}$ & $46055^{\prime} 58^{\prime \prime}$ & -.. & K.Santos & 164 & $11 / 22 / 91$ \\
\hline Crotonfloribundus Spreng. & -.- & UEC & 110349 & 9 Brasil & São Paulo & Campinas & $22050^{\prime} 13 " \mathrm{~S}$ & $46055^{\prime} 58^{\prime \prime}$ & -.. & T.Spenelli et al. & 239 & $1 / 31 / 0$ \\
\hline Crotonfloribundus Spreng. & --- & UEC & 109301 & 1 Brasil & São Paulo & Campinas & $22050^{\prime} 13 " \mathrm{~S}$ & $46055^{\prime} 58^{\prime \prime}$ & $\cdots$ & S.S.Constancio et al. & 182 & 10/25/9! \\
\hline Crotonfloribundus Spreng. & -.- & UEC & 108393 & 3 Brasil & São Paulo & Campinas & $22049^{\prime} 45^{\prime \prime S}$ & $4700633^{\prime \prime}$ & -.. & M.T.G-Guaratini et al. & 227 & $10 / 18 / 9^{\prime}$ \\
\hline Crotonfloribundus Spreng. & --- & UEC & 4650 & 0 Brasil & São Paulo & Campinas & $22050^{\prime} 13 " \mathrm{~S}$ & $46055^{\prime} 58^{\prime \prime}$ & -.. & L.F.Matthes & 7653 & st \\
\hline Croton floribundus Spreng. & -.- & UEC & 46511 & 1 Brasil & São Paulo & Campinas & $22050^{\prime} 13 " \mathrm{~S}$ & $46055^{\prime} 58^{\prime \prime}$ & ... & I.Sazima & 18927 & 12/30/81 \\
\hline Crotonfloribundus Spreng. & -.- & UEC & 53320 & 0 Brasil & São Paulo & Campinas & $22050^{\prime} 13 " \mathrm{~S}$ & $46055^{\prime} 58 "$ & -.. & S.G.Egler & 22153 & 10/24/8: \\
\hline Crotonfloribundus Spreng. & -.- & UEC & 47069 & 9 Brasil & São Paulo & Campinas & $22050^{\prime} 13 " \mathrm{~S}$ & $46055^{\prime} 58 "$ & -.. & V.L.CV.Arruda & 19817 & 10/31/8: \\
\hline Croton floribundus Spreng. & --- & UEC & 69049 & 9 Brasil & São Paulo & Campinas & $22050^{\prime} 13 " \mathrm{~S}$ & $4605558 "$ & -- & L.C.Passos & 32543 & 12/27/9. \\
\hline Croton floribundus Spreng. & --. & UEC & 68882 & 2 Brasil & São Paulo & Campinas & $22050^{\prime} 13 " \mathrm{~S}$ & $4605558 "$ & -- & L.C.Passos & 32541 & 12/27/9. \\
\hline Crotonfloribundus Spreng. & -.. & UEC & 47306 & 6 Brasil & São Paulo & Campinas & $22052^{\prime} 00^{\prime \prime} \mathrm{S}$ & $46005^{\prime} 00^{\prime \prime}$ & & 550 "Gentry et al. & 58744 & $8 / 27 / 8^{\circ}-1-18$ \\
\hline Crotonfloribundus Spreng. & -.- & UEC & 68877 & 7 Brasil & São Paulo & Campinas & $22050^{\prime} 13 " \mathrm{~S}$ & $46055^{\prime} 58 "$ & -.. & L.C.Passos & 32542 & 12/27/9. \\
\hline Croton floribundus Spreng. & -.- & UEC & 45304 & 4 Brasil & São Paulo & Campinas & $22050^{\prime} 13 " \mathrm{~S}$ & $46055^{\prime} 58^{\prime \prime}$ & ... & H.F.Leitão et al. & 17947 & 11/21/8: \\
\hline Crotonfloribundus Spreng. & --- & UEC & 4652 & 2 Brasil & São Paulo & Campins B. dos Jequitivas & $\cdots$ & -- & $\cdots$ & L.F.Matthes & 7651 & st \\
\hline Crotonfloribundus Spreng. & ... & UEC & 4649 & 9 Brasil & São Paulo & Campins B. dos Jequitivas & ... & -.- & ... & L.a.F.Matthes & 7650 & st \\
\hline Crotonfloribundus Spreng. & $\ldots$ & $\mathrm{SP}$ & 297571 & 1 Brasil & São Paulo & Cândido Mota & $\ldots$ & $\ldots$ & $\ldots$ & V.C.Souza et al. & 9693 & 12/20/9: \\
\hline
\end{tabular}




\begin{tabular}{|c|c|c|c|c|c|c|c|c|c|c|c|c|}
\hline \multirow{2}{*}{$\begin{array}{l}\text { Espécie } \\
\text { N.científico }\end{array}$} & \multirow[b]{2}{*}{ N. vulgar } & \multicolumn{2}{|c|}{ Herbário } & \multicolumn{2}{|c|}{ Localidade } & \multirow[b]{2}{*}{ Município } & \multirow[b]{2}{*}{$\begin{array}{l}\text { Latitude } \\
\quad\left({ }^{\circ} \mathrm{S}, \mathrm{S}\right)\end{array}$} & \multirow[b]{2}{*}{$\begin{array}{r}\text { Longitude } \\
\left({ }^{\circ} \mathrm{S}, \mathrm{W}\right)\end{array}$} & \multirow[b]{2}{*}{$\begin{array}{c}\text { Altitude } \\
\text { (manm) }\end{array}$} & \multicolumn{3}{|l|}{ COLETOR } \\
\hline & & Sigla & Registro & País & Estado & & & & & Nome/número & & Data \\
\hline Croton floribundus Spreng. & Capixingui & SPSF & 5829 & 9 Brasil & $\begin{array}{l}\text { São Paulo } \\
\end{array}$ & Capital & $23033^{\circ} 00^{\prime \prime S}$ & $46043^{\prime} 00^{\prime \prime}$ & & 50 J.B. Baitello \& ${ }^{\circ}$ T. Aguia & & $11 / 13 / 7$ \\
\hline Crotonfloribundus Spreng. & Capixingui & SPSF & 8809 & 9 Brasil & São Paulo & Capital & $23033^{\circ} 00^{\prime \prime S}$ & $46043^{\prime} 00^{\prime \prime}$ & & ${ }^{\circ} \mathrm{T}$. Aguair \& J.a Pastore & & $11 / 29 / 9$ \\
\hline Croton floribundus Spreng. & Capixingui & SPSF & 6350 & 0 Brasil & São Paulo & Capital & $23033^{\circ} 00^{\prime \prime} \mathrm{s}$ & $46043^{\prime} 00^{\prime \prime}$ & & M. Koscinski & $\mathrm{sn}$ & $00 / 02 / 193$ \\
\hline Croton floribundus Spreng. & Capixingui & SPSF & 8843 & 3 Brasil & São Paulo & Capital & $23033^{\circ} 00^{\prime \prime} \mathrm{s}$ & $46043^{\prime} 00^{\prime \prime}$ & & E. Lopes \& L.C. Pastore & $\mathrm{sn}$ & $12 / 18 / 8$ \\
\hline Croton floribundus Spreng. & Capixingui & SPSF & 7201 & 1 Brasil & São Paulo & Capital & (Serra da Ca & & & M. Koscinski & $\mathrm{sn}$ & $00 / 12 / 193$ \\
\hline Croton floribundus Spreng. & -.- & $\mathrm{SP}$ & 296911 & 1 Brasil & São Paulo & Cássia dos Coqueiros & $21028^{\circ} 00^{\prime \prime S}$ & $47017^{\prime} 00^{\prime \prime}$ & -.. & ${ }^{a}$ M.G. ${ }^{\text {aT }}$ ozzzi et al & $94-96$ & $11 / 9 / 9$ \\
\hline Croton floribundus Spreng. & -- & SP & 254064 & 4 Brasil & São Paulo & Ciudade Jardim & -.- & -.- & -.- & S.Corrêa et al. & 703 & $11 / 22 / 9$ \\
\hline Croton floribundus Spreng. & -.. & SP & 312916 & 6 Brasil & São Paulo & Cotia & -.- & -.. & -.- & L.Rossi et al. & $\mathrm{sn}$ & $10 / 30 / 8$ \\
\hline Croton floribundus Spreng. & ..- & UEC & 111058 & 8 Brasil & São Paulo & Cotia & ... & ... & ... & F.de Barros & 2397 & $12 / 8 / 9$ \\
\hline Croton floribundus Spreng. & -.- & SPF & 114576 & 6 Brasil & São Paulo & Divinolândia & -.- & --. & -.- & Kinoshita L.S. et al & 94 & $11 / 8 / 9$ \\
\hline Crotonfloribundus Spreng. & --. & $\mathrm{SP}$ & 296944 & 4 Brasil & São Paulo & Divnolândia & -.- & --. & -.. & L.S.Kimoshita et al. & $94-73$ & $11 / 8 / 9$ \\
\hline Croton floribundus Spreng. & -.. & SP & 296943 & 3 Brasil & São Paulo & Divnolândia & -.- & -.. & -.- & L.S.Kimoshita et al. & 9474 & $11 / 8 / 9$ \\
\hline Croton floribundus Spreng. & -.- & UEC & 78170 & 0 Brasil & São Paulo & Gália & $22015^{\prime} 00^{\prime \prime S}$ & $49030^{\prime} 00^{\prime \prime}$ & ... & F.C. Passo et al. & 36 & $6 / 26 / 9$ \\
\hline Croton floribundus Spreng. & -.- & вотU & 6940 & 0 Brasil & São Paulo & Garça & -.- & --. & -.- & J.R.daCunha & 20 & $00 / 08 / 211$ \\
\hline Croton floribundus Spreng. & -.- & UEC & 112671 & 1 Brasil & São Paulo & Guarantingueta & $22051^{\prime 30 " \mathrm{~s}}$ & $45010^{\prime} 00^{\prime \prime}$ & 75 & 50 D.C.Cavalcanti & 278 & $1 / 23 / 9$ \\
\hline Croton floribundus Spreng. & -.- & $\mathrm{SP}$ & 291900 & 0 Brasil & São Paulo & Ipeúma & -.- & -- & -.- & R.R.Rodrigues et al. & $\mathrm{sn}$ & $11 / 25 / 8$ \\
\hline Croton floribundus Spreng. & -.- & $\mathrm{RB}$ & 100755 & 5 Brasil & São Paulo & Itapetininga & 23034'00" & $48000^{\circ} 00^{\prime \prime}$ & -.. & aLofgren & 427 & $04 / 12 / 188$ \\
\hline Croton floribundus Spreng. & -.- & $\mathrm{SP}$ & 287126 & 6 Brasil & São Paulo & Itararé & $23033^{\prime} 00^{\prime \prime} \mathrm{s}$ & $46043^{\prime} 00^{\prime \prime}$ & 756 & 50 P.H.Miyagi et al. & 399 & $2 / 12 / 9$ \\
\hline Croton floribundus Spreng. & -.- & $\mathrm{SP}$ & 340463 & 3 Brasil & São Paulo & Itararé & $23033^{\circ} 00^{\prime \prime} \mathrm{s}$ & $46043^{\prime} 00^{\prime \prime}$ & 75 & 50 v.C.Souza et al. & 4558 & $30-\mathrm{O}$ \\
\hline Croton floribundus Spreng. & -.- & UEC & 83298 & 8 Brasil & São Paulo & Itararé & $23033^{\circ} 00^{\prime \prime} \mathrm{s}$ & $46043^{\prime} 00^{\prime \prime}$ & 75 & $50{ }^{\mathrm{a}} \mathrm{C}$. Cerci & 3299 & $11 / 29 / 9$ \\
\hline Crotonfloribundus Spreng. & -.- & $\mathrm{SP}$ & 292080 & 0 Brasil & São Paulo & Jabaquaba & -.- & -.. & -.- & ${ }^{\circ}$ Eduardo & $\mathrm{sn}$ & $10 / 10 / 8$ \\
\hline Croton floribundus Spreng. & Capixingui & SP & 245635 & 5 Brasil & São Paulo & Jaboticabal & -.- & -.- & -.- & E.H. ${ }^{a}$ Rodrigues & 8 & $4 / 15 / 9$ \\
\hline Croton floribundus Spreng. & --- & HRCB & 11977 & 7 Brasil & São Paulo & Jabu & -.- & -.- & -.- & Nicoline & $\mathrm{sn}$ & $00 / 00 / 198$ \\
\hline Croton floribundus Spreng. & Capiacingui & SPSF & 9138 & 8 Brasil & São Paulo & José de Bonifácio & $23033^{\circ} 00^{\prime \prime S}$ & $46043^{\prime} 00^{\prime \prime}$ & 751 & 50 De Lucas et al. & 786 & $12 / 4 / 8$ \\
\hline Croton floribundus Spreng. & --- & SP & 29222 & 2 Brasil & São Paulo & Jundiaí & $23015^{\prime} 00^{\prime \prime S}$ & $46015^{\prime} 00^{\prime \prime}$ & -.- & L.P.C.Morellato-Monzar & sn & $11 / 19 / 8$ \\
\hline Croton floribundus Spreng. & -.- & UEC & 49177 & 7 Brasil & São Paulo & Jundiaí & $23015^{\prime} 00^{\prime \prime} \mathrm{s}$ & $46015^{\prime} 00^{\prime \prime}$ & -.- & L.P.C.M-Forgar et al. & 16634 & $10 / 22 / 8$ \\
\hline Croton floribundus Spreng. & -.. & UEC & 40279 & 9 Brasil & São Paulo & Jundiaí & $23015^{\prime} 00^{\prime \prime} \mathrm{s}$ & $46015^{\prime} 00^{\prime \prime}$ & -.- & L.P.C.M-Forgar et al. & 16721 & $11 / 6 / 8$ \\
\hline Crotonfloribundus Spreng. & --- & UEC & 40643 & 3 Brasil & São Paulo & Jundiaí & $23015^{\circ} 00^{\prime \prime} \mathrm{s}$ & $46015^{\prime} 00^{\prime \prime}$ & -.- & L.P.C.M-Forgar et al. & 16793 & $12 / 13 / 8$ \\
\hline Croton floribundus Spreng. & -.- & UEC & 40262 & 2 Brasil & São Paulo & Jundiaí & $23015^{\prime} 00^{\prime \prime} \mathrm{s}$ & $46015^{\prime} 00^{\prime \prime}$ & -.- & L.P.C.M-Forgar et al. & $\mathrm{sn}$ & $11 / 19 / 8$ \\
\hline Croton floribundus Spreng. & -.- & UEC & 40645 & 5 Brasil & São Paulo & Jundiaí & $23015^{\prime} 00^{\prime \prime} \mathrm{s}$ & $46015^{\prime} 00^{\prime \prime}$ & -.- & L.P.C.M-Forgar et al. & 16687 & $10 / 22 / 8$ \\
\hline Croton floribundus Spreng. & --. & UEC & 40756 & 6 Brasil & São Paulo & Jundiaí & $23015^{\prime} 00^{\prime \prime} \mathrm{s}$ & $46015^{\prime} 00^{\prime \prime}$ & -.- & L.P.C.M-Forgar et al. & 16688 & $10 / 22 / 8$ \\
\hline Croton floribundus Spreng. & --. & UEC & 114996 & 6 Brasil & São Paulo & Jundiaí & $23015^{\prime} 00^{\prime \prime} \mathrm{s}$ & $46015^{\prime} 00^{\prime \prime}$ & -.- & E.L.Cardoso & 411 & $3 / 13 / 9$ \\
\hline Croton floribundus Spreng. & -.. & UEC & 102880 & 0 Brasil & São Paulo & Jundiaí & $23015^{\prime} 00^{\prime \prime} \mathrm{s}$ & $46015^{\prime} 00^{\prime \prime}$ & -.- & E.R.Pasarim & 374 & $11 / 30 / 9$ \\
\hline Croton floribundus Spreng. & Capixingui & вотU & 7252 & 2 Brasil & São Paulo & Laranjal Paulista & -.- & -.- & -.- & S.L.B.Ulizna & 41 & $00 / 08 / 211$ \\
\hline Croton floribundus Spreng. & -.- & $\mathrm{SP}$ & 29521 & 1 Brasil & São Paulo & Limeira & ... & -.. & -.. & -.. & 46 & $<193$ \\
\hline Croton floribundus Spreng. & --- & $\mathrm{SP}$ & 232918 & 8 Brasil & São Paulo & Limeira & -- & --- & -.- & E.Kuhn & 28 & $10 / 31 / 5$ \\
\hline Croton floribundus Spreng. & Capixingui & $\mathrm{RB}$ & 16215 & 5 Brasil & São Paulo & Loreto & -.. & -.- & -.. & ${ }^{\circ}$ Vecchi & 44 & $x^{2}$ \\
\hline Croton floribundus Spreng. & ... & SPF & 51088 & 8 Brasil & São Paulo & Matinha & $\ldots$ & $\ldots$ & $\ldots$ & Rossi L. & 363 & $10 / 30 / 8$ \\
\hline
\end{tabular}


Informação do material botânico nos herbários do gênero Croton

(Continuação)

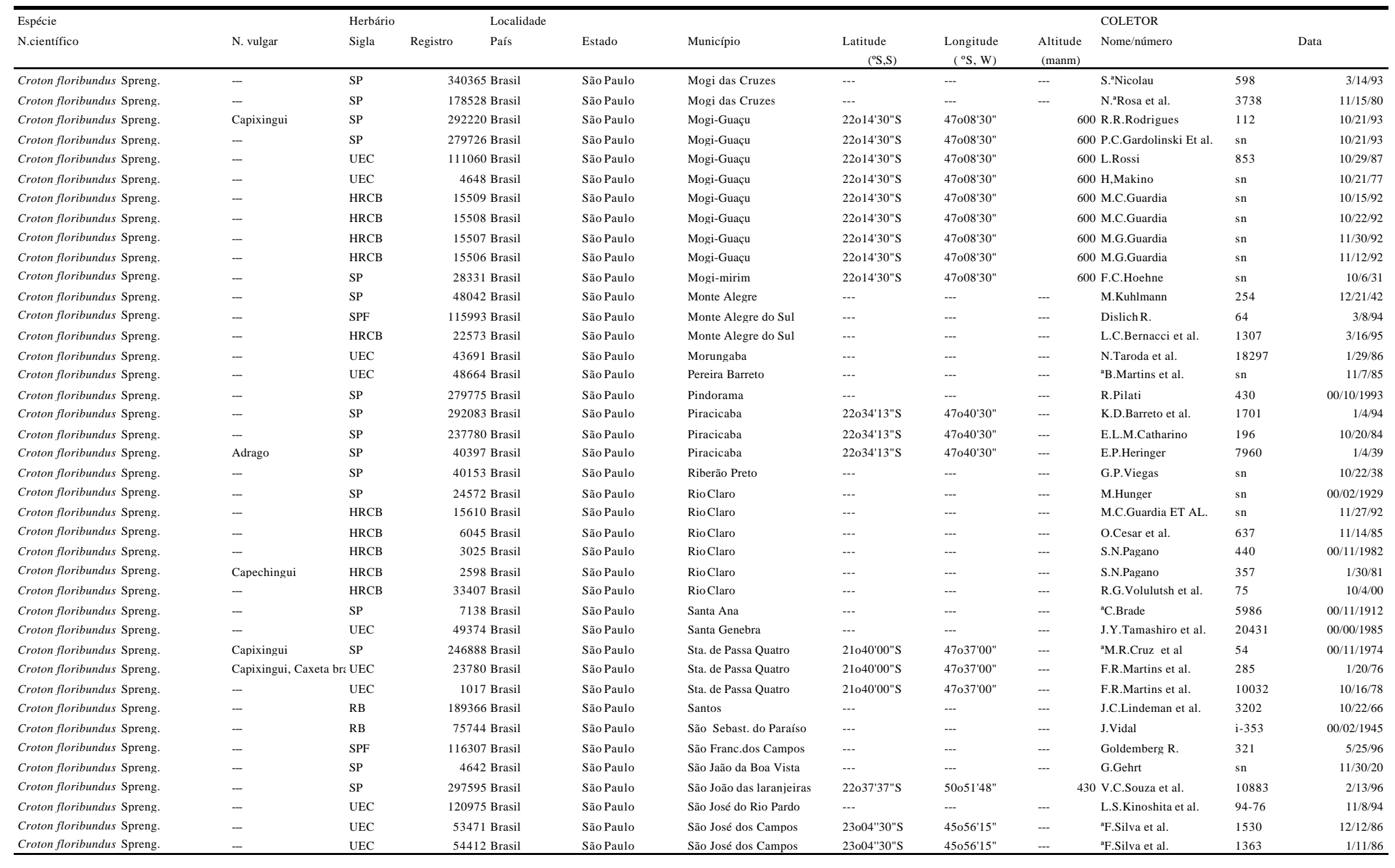




\begin{tabular}{|c|c|c|c|c|c|c|c|c|c|c|c|c|c|}
\hline \multirow{2}{*}{$\begin{array}{l}\text { Espécie } \\
\text { N.científico }\end{array}$} & \multirow[b]{2}{*}{ N. vulgar } & \multicolumn{3}{|l|}{ Herbário } & \multicolumn{2}{|l|}{ Localidade } & \multirow[b]{2}{*}{ Município } & \multirow{2}{*}{$\begin{array}{c}\text { Latitude } \\
\left({ }^{\circ}, S\right) \\
\end{array}$} & \multirow{2}{*}{$\begin{array}{r}\text { Longitude } \\
\left({ }^{\circ} \mathrm{S}, \mathrm{W}\right)\end{array}$} & \multirow[b]{2}{*}{ Altitude } & \multicolumn{2}{|l|}{ COLETOR } & \multirow[b]{2}{*}{ Data } \\
\hline & & Sigla & Regist & & País & Estado & & & & & Nome/número & & \\
\hline Croton floribundus Spreng. & $\cdots$ & UEC & $\mathrm{sn}$ & & Brasil & São Paulo & São Juão das Laranjéiras & $2203737 " \mathrm{~S}$ & $50051^{\prime} 48^{\prime \prime}$ & $\cdots$ & V.C.Souza et al. & 10884 & $2 / 13 / 9$ \\
\hline Crotonfloribundus Spreng. & -.. & SP & & 99433 & 3 Brasil & São Paulo & Saõ Paulo & $23033^{\prime} 00 " \mathrm{~S}$ & $46043^{\prime} 00^{\prime \prime}$ & & 750 R.Faria et al. & $\mathrm{sn}$ & $11 / 24 / 6$ \\
\hline Croton floribundus Spreng. & -.- & SPF & & 115911 & I Brasil & São Paulo & São Paulo & $23033^{\prime} 00^{\prime \prime S}$ & $46043^{\prime} 00^{\prime \prime}$ & & 750 Dislich R. & 52 & 2/3/9. \\
\hline Croton floribundus Spreng. & -.. & SPF & & 112694 & 4 Brasil & São Paulo & São Paulo & $23033^{\circ} 00^{\prime \prime S}$ & $46043^{\prime} 00^{\prime \prime}$ & -.- & Rossi L. & 115 & $11 / 8 / 7$ \\
\hline Crotonfloribundus Spreng. & -.- & SPF & & 115988 & 3 Brasil & São Paulo & São Paulo & $23033^{\prime} 00^{\prime \prime} \mathrm{S}$ & $46043^{\prime} 00^{\prime \prime}$ & -. & Dislich R. & 46 & 2/1/9. \\
\hline Crotonfloribundus Spreng. & -..- & SPF & & 115987 & Brasil & São Paulo & São Paulo & $23033^{\prime} 00 " \mathrm{~S}$ & $46043^{\prime} 00^{\prime \prime}$ & -.- & Dislich R. & 44 & $2 / 1 / 9$ \\
\hline Croton floribundus Spreng. & -.- & SPF & & 115990 & Brasil & São Paulo & São Paulo & $23033^{\prime} 00^{\prime \prime} \mathrm{S}$ & $46043^{\prime} 00^{\prime \prime}$ & -.- & Dislich R. & 48 & 2/1/9. \\
\hline Croton floribundus Spreng. & --- & SPF & & 115992 & 2 Brasil & São Paulo & São Paulo & $23033^{\prime} 00^{\prime \prime S}$ & $46043^{\prime} 00^{\prime \prime}$ & -.- & Dislich R. & 58 & 3/7/9. \\
\hline Crotonfloribundus Spreng. & Capixinguí & SPF & sn & & Brasil & São Paulo & São Paulo & $23033^{\prime} 00^{\prime \prime S}$ & $46043^{\prime} 00^{\prime \prime}$ & -.- & Hoehne W. & 13302 & $11 / 13 / 4$ \\
\hline Crotonfloribundus Spreng. & Andrajo Barca & SPF & & 112693 & 3 Brasil & São Paulo & São Paulo & $23033^{\prime} 00^{\prime \prime S}$ & $46043^{\prime} 00^{\prime \prime}$ & ... & Rossi L. & 102 & $10 / 25 / 7$ \\
\hline Crotonfloribundus Spreng. & --- & SPF & & 107562 & 2 Brasil & São Paulo & São Paulo & $23039^{\prime} 47 " \mathrm{~S}$ & $4604621 "$ & -. & Bernacci L.C. & 1307 & $3 / 16 / 9$ \\
\hline Croton floribundus Spreng. & -.. & SPF & & 16590 & Brasil & São Paulo & São Paulo & $23039^{\prime} 47 \mathrm{~s}$ & $4604621 "$ & -.- & Rawitscher R. & $\mathrm{sn}$ & $12 / 11 / 4$ \\
\hline Croton floribundus Spreng. & -.- & SPF & & 121035 & 5 Brasil & São Paulo & São Paulo & $23039^{\prime} 47^{\prime \prime S}$ & $4604621 "$ & -.- & García RJF. & 223 & $11 / 13 / 9$ \\
\hline Crotonfloribundus Spreng. & -.- & SPF & & 112695 & 5 Brasil & São Paulo & São Paulo & $23039^{\prime} 47 " \mathrm{~S}$ & $4604621 "$ & -.- & Rossi L. & 136 & $12 / 6 / 7$ \\
\hline Croton floribundus Spreng. & -.- & SPF & & 115989 & Brasil & São Paulo & São Paulo & $23039^{\prime} 47 " \mathrm{~S}$ & $4604621 "$ & -. & Dislich R. & 47 & 2/1/9. \\
\hline Croton floribundus Spreng. & --- & SPF & & 51382 & 2 Brasil & São Paulo & São Paulo & $23033^{\prime} 00^{\prime \prime S}$ & $46043^{\prime} 00^{\prime \prime}$ & & 750 Honda S. et al & 840 & $2 / 10 / 8$ \\
\hline Croton floribundus Spreng. & Capixinguí & SPF & $\mathrm{s} / \mathrm{n}$ & & Brasil & São Paulo & São Paulo & $23033^{\prime} 00^{\prime \prime S}$ & $46043^{\prime} 00^{\prime \prime}$ & & 750 Hoehne $\mathrm{W}$. & 10229 & $12 / 27 / 3$ \\
\hline Crotonfloribundus Spreng. & -.- & SP & & 312917 & Brasil & São Paulo & São Paulo & $23033^{\prime} 00 " \mathrm{~S}$ & $46043^{\prime} 00^{\prime \prime}$ & & 750 S.P.P.Godoy et al & 331 & $1 / 16 / 9$ \\
\hline Croton floribundus Spreng. & -.- & SP & & 28526 & 5 Brasil & São Paulo & São Paulo & $23033^{\prime} 00 " \mathrm{~s}$ & $46043^{\prime} 00^{\prime \prime}$ & & 750 F.C.Hoehne & $\mathrm{sn}$ & $11 / 25 / 3$ \\
\hline Croton floribundus Spreng. & -.. & $\mathrm{SP}$ & & 204092 & 2 Brasil & São Paulo & São Paulo & $23033^{\circ} 00^{\prime \prime S}$ & $46043^{\prime} 00^{\prime \prime}$ & & 750 M.Goes et al. & $\mathrm{sn}$ & $12 / 29 / 7$ \\
\hline Croton floribundus Spreng. & -.- & SP & & 247158 & 3 Brasil & São Paulo & São Paulo & $23033^{\prime} 00 " \mathrm{~s}$ & $46043^{\prime} 00^{\prime \prime}$ & & 750 aM.R.Cruz et al & $\mathrm{sn}$ & $00 / 12 / 197$ \\
\hline Croton floribundus Spreng. & -.. & $\mathrm{SP}$ & & 32228 & Brasil & São Paulo & São Paulo & $23033^{\circ} 00^{\prime \prime S}$ & $46043^{\prime} 00^{\prime \prime}$ & & 750 E.J.Hambleton & 4 & $1 / 6 / 3$ \\
\hline Croton floribundus Spreng. & -.- & SP & & 319925 & Brasil & São Paulo & São Paulo & $21040^{\circ} 00^{\prime \prime S}$ & $47039^{\circ} 00^{\prime \prime}$ & -.. & M. ${ }^{\text {BB Batalha }}$ & 1507 & $11 / 7 / 9$ \\
\hline Crotonfloribundus Spreng. & -.- & SP & & 346886 & 5 Brasil & São Paulo & São Paulo & $23033^{\prime} 00 " \mathrm{~S}$ & $46043^{\prime} 00^{\prime \prime}$ & & 750 S. ${ }^{.}$Nicolau et al. & 218 & $12 / 22 / 9$ \\
\hline Croton floribundus Spreng. & -.- & $\mathrm{SP}$ & & 109812 & 2 Brasil & São Paulo & São Paulo & $23033^{\circ} 00^{\prime \prime S}$ & $46043^{\prime} 00^{\prime \prime}$ & & 750 J.C.Camargo et al. & 5 & $2 / 3 / 6$ \\
\hline Croton floribundus Spreng. & --- & $\mathrm{SP}$ & & 167505 & 5 Brasil & São Paulo & São Paulo & $23033^{\prime} 00^{\prime \prime S}$ & $46043^{\prime} 00^{\prime \prime}$ & 75 & 750 a'Custodio Fo. & 391 & $10 / 23 / 8$ \\
\hline Crotonfloribundus Spreng. & -.- & SP & & 272582 & 2 Brasil & São Paulo & São Paulo & $23033^{\prime} 00^{\prime \prime S}$ & $46043^{\prime} 00^{\prime \prime}$ & & 750 M.Kawall & 255 & $11 / 19 / 9$ \\
\hline Croton floribundus Spreng. & -.. & SP & & 1064 & 4 Brasil & São Paulo & São Paulo & $23033^{\prime} 00^{\prime \prime S}$ & $46043^{\prime} 00^{\prime \prime}$ & 75 & 750 F.C.Hoehne & $\mathrm{sn}$ & $12 / 12 / 1$ \\
\hline Crotonfloribundus Spreng. & -.- & SP & & 32182 & 2 Brasil & São Paulo & São Paulo & $23033^{\prime} 00^{\prime \prime S}$ & $46043^{\prime} 00^{\prime \prime}$ & & 750 S.Enn & $\mathrm{sn}$ & $12 / 7 / 3$ \\
\hline Croton floribundus Spreng. & --- & $\mathrm{SP}$ & & 42209 & Brasil & São Paulo & São Paulo & $23033^{\prime} 00^{\prime \prime S}$ & $46043^{\prime} 00^{\prime \prime}$ & & 750 B.Pickel & $\mathrm{sn}$ & $11 / 30 / 3$ \\
\hline Crotonfloribundus Spreng. & -.- & SP & & 279750 & Brasil & São Paulo & São Paulo & $23033^{\prime} 00^{\prime \prime S}$ & $46043^{\prime} 00^{\prime \prime}$ & 75 & 750 S. .P. Godoy et al. & 537 & 5/23/9. \\
\hline Croton floribundus Spreng. & -.- & UEC & & 111056 & 5 Brasil & São Paulo & São Paulo & $23033^{\prime} 00 " \mathrm{~s}$ & $46043^{\prime} 00^{\prime \prime}$ & 75 & 750 F.C. Hoehne & sn & $11 / 25 / 3$ \\
\hline Crotonfloribundus Spreng. & -.- & UEC & & 111063 & 3 Brasil & São Paulo & São Paulo & $23033^{\prime} 00 " \mathrm{~s}$ & $46043^{\prime} 00^{\prime \prime}$ & & 750 R.Faria et al. & $\mathrm{sn}$ & $11 / 24 / 6$ \\
\hline Croton floribundus Spreng. & --- & UEC & & 110933 & B Brasil & São Paulo & São Paulo & $23033^{\prime} 00^{\prime \prime} \mathrm{S}$ & $46043^{\prime} 00^{\prime \prime}$ & & 750 M.Goes et al. & $\mathrm{sn}$ & $12 / 29 / 7$ \\
\hline Crotonfloribundus Spreng. & -.- & UEC & & 110932 & 2 Brasil & São Paulo & São Paulo & $23033^{\prime} 00^{\prime \prime S}$ & $46043^{\prime} 00^{\prime \prime}$ & & 750 L.B.Noffs et al. & 39 & $11 / 17 / 7$ \\
\hline Croton floribundus Spreng. & -.- & UEC & & 110931 & I Brasil & São Paulo & São Paulo & $23033^{\prime} 00 " \mathrm{~s}$ & $46043^{\prime} 00^{\prime \prime}$ & & 750 S.L.Jump et al. & 193 & $11 / 8 / 7$ \\
\hline Croton floribundus Spreng. & --- & UEC & & 61793 & 3 Brasil & São Paulo & São Paulo & $23033^{\prime} 00^{\prime \prime S}$ & $46043^{\prime} 00^{\prime \prime}$ & 75 & 750 L.C.Bernacci & 24448 & $11 / 8 / 8$ \\
\hline Crotonfloribundus Spreng. & $\ldots$ & HRCB & & 6446 & Brasil & São Paulo & São Paulo & $23033^{\circ} 00^{\prime \prime S}$ & $46043^{\prime} 00^{\prime \prime}$ & 75 & 750 I.E.Sutra & sn & $11 / 11 / 8$ \\
\hline
\end{tabular}




\begin{tabular}{|c|c|c|c|c|c|c|c|c|c|c|c|c|}
\hline \multirow{2}{*}{$\begin{array}{l}\text { Espécie } \\
\text { N.científico }\end{array}$} & \multirow[b]{2}{*}{ N. vulgar } & \multicolumn{2}{|c|}{ Herbário } & \multicolumn{2}{|l|}{ Localidade } & \multirow[b]{2}{*}{ Município } & \multirow[b]{2}{*}{ 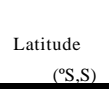 } & \multirow[b]{2}{*}{$\begin{array}{r}\text { Longitude } \\
\left({ }^{\circ} \mathrm{S}, \mathrm{W}\right) \\
\end{array}$} & \multirow[b]{2}{*}{$\begin{array}{c}\text { Altitude } \\
\text { (manm) }\end{array}$} & \multicolumn{3}{|l|}{ COLETOR } \\
\hline & & Sigla & Registro & País & Estado & & & & & Nome/número & & ata \\
\hline Croton floribundus Spreng. & --- & $\mathrm{SP}$ & 304610 & 0 Brasil & São Paulo & São Pedro & $-\ldots$ & - & -- & V.C.Souza et al. & 4878 & $12 / 4 / 9$ \\
\hline Crotonfloribundus Spreng. & Capixingui & UEC & 80504 & 4 Brasil & São Paulo & São Roque & $2303126 " \mathrm{~S}$ & $47006^{\prime} 45^{\prime \prime}$ & -.- & C.Leite et al. & 121 & $7 / 26 / 9$ \\
\hline Crotonfloribundus Spreng. & Capixingui & UEC & 80506 & 6 Brasil & São Paulo & São Roque & $23021^{\prime} 26 " \mathrm{~S}$ & $47006^{\prime 45 "}$ & -.. & C.Leite et al. & 94 & $7 / 25 / 9$ \\
\hline Crotonfloribundus Spreng. & --- & $\mathrm{SP}$ & 64456 & 6 Brasil & São Paulo & São Simão & $\cdots$ & --- & -.- & -- & $\mathrm{sn}$ & $11 / 29 / 61$ \\
\hline Croton floribundus Spreng. & -.- & UEC & 111057 & 7 Brasil & São Paulo & São Simão & -.- & -.. & -.- & J.Mattos & 8646 & $11 / 29 / 61$ \\
\hline Croton floribundus Spreng. & -.. & SP & 31241 & 1 Brasil & São Paulo & Serra da Cantareira & -.- & -.- & -.- & M.Koscinsky & $\mathrm{sn}$ & $00 / 12 / 193$ \\
\hline Croton floribundus Spreng. & -.- & UEC & 111059 & 9 Brasil & São Paulo & Serra Negra & -- & -.- & 1000 & F.de Barros et al. & 2352 & $11 / 22 / 9$ \\
\hline Croton floribundus Spreng. & -.- & SPF & 147815 & 5 Brasil & São Paulo & Socorro & $22035^{\circ} 00^{\prime \prime S}$ & $46031^{\prime} 00^{\prime \prime}$ & -.- & Groppo M. & 840 & $8 / 25 / 0$ \\
\hline Croton floribundus Spreng. & Capixingui & HRCB & 27435 & 5 Brasil & São Paulo & Socorro & -.- & -- & -.- & "M.S.Pitolli & 8 & 10/5/91 \\
\hline Croton floribundus Spreng. & -.- & UEC & 86114 & 4 Brasil & São Paulo & Taguaí & -.- & -.. & -.- & J.Y.Tamashiro et al. & 674 & 9/28/8. \\
\hline Croton floribundus Spreng. & -.. & SPSF & 12203 & 3 Brasil & São Paulo & Teodoro sampaio & $22032^{\prime} 00^{\prime \prime} \mathrm{S}$ & $52015^{\prime} 00^{\prime \prime}$ & & J.Y. Tamashiro et al & $\mathrm{sn}$ & 12/2/81 \\
\hline Croton floribundus Spreng. & Capixingui & SPSF & 13516 & 6 Brasil & São Paulo & Teodoro sampaio & $22032^{\prime} 00^{\prime \prime S}$ & $52015^{\prime} 00^{\prime \prime}$ & & E.C. Da Fonseca & $\mathrm{sn}$ & $11 / 16 / 8$ \\
\hline Croton floribundus Spreng. & Capixingui & SPSF & 11339 & 9 Brasil & São Paulo & Teodoro sampaio & $22032^{\prime} 00^{\prime \prime S}$ & $52015^{\prime} 00^{\prime \prime}$ & & U. Pastore \& R.M. Klein & 154 & $10 / 27 / 81$ \\
\hline Croton floribundus Spreng. & Capixingui & SPSF & 11692 & 2 Brasil & São Paulo & Teodoro sampaio & $22032^{\prime} 00^{\prime \prime} \mathrm{S}$ & $52015^{\prime} 00^{\prime \prime}$ & & a.L.K.M. Albernaz & sn & $11 / 16 / 8^{\prime}$ \\
\hline Croton floribundus Spreng. & -.. & SPSF & 12284 & 4 Brasil & São Paulo & Teodoro sampaio & $22032^{\prime} 00^{\prime \prime S}$ & $52015^{\prime} 00^{\prime \prime}$ & & J.Y. Tamashiro et al & sn & $12 / 4 / 8$ \\
\hline Croton floribundus Spreng. & -.- & SPSF & 17870 & 0 Brasil & São Paulo & Teodoro sampaio & $22032^{\prime} 00^{\prime \prime S}$ & $52015^{\prime} 00^{\prime \prime}$ & & J.B. Baitello & 735 & $12 / 7 / 9$ \\
\hline Croton floribundus Spreng. & Capixingui & SPSF & 9507 & 7 Brasil & São Paulo & Teodoro sampaio & $22032^{\prime} 00^{\prime \prime S}$ & $52015^{\prime} 00^{\prime \prime}$ & & J.B. Baitello & 164 & 10/23/8: \\
\hline Croton floribundus Spreng. & ..- & SPF & 96966 & 6 Brasil & São Paulo & Teodoro Sampaio & $22032^{\prime} 00^{\prime \prime} \mathrm{S}$ & $52015^{\prime} 00^{\prime \prime}$ & -.. & Baitello J.B. & 735 & $12 / 7 / 9$ \\
\hline Croton floribundus Spreng. & -.. & $\mathrm{SP}$ & 237491 & 1 Brasil & São Paulo & Teodoro Sampaio & $22032^{\prime} 00^{\prime \prime} \mathrm{S}$ & $52015^{\prime} 00^{\prime \prime}$ & -.- & J.B.Baitello & 164 & 10/23/8: \\
\hline Croton floribundus Spreng. & -.- & SP & 279735 & 5 Brasil & São Paulo & Teodoro Sampaio & $22032^{\prime} 00^{\prime \prime S}$ & $52015^{\prime} 00^{\prime \prime}$ & -.- & J.B.Baitello & 735 & $12 / 7 / 9$ \\
\hline Croton floribundus Spreng. & Capixingui & UEC & 87322 & 2 Brasil & São Paulo & Teodoro Sampaio & $22032^{\prime} 00^{\prime \prime} \mathrm{S}$ & $52015^{\prime} 00^{\prime \prime}$ & -. & J.B.Baitello & 735 & $12 / 7 / 9$ \\
\hline Croton floribundus Spreng. & -.- & UEC & 15012 & 2 Brasil & São Paulo & Teodoro Sampaio & $22032^{\prime} 00^{\prime \prime} \mathrm{S}$ & $52015^{\prime} 00^{\prime \prime}$ & -.. & J.Y.Tamashiro et al. & 18809 & 12/2/81 \\
\hline Crotonfloribundus Spreng. & --. & $\mathrm{SP}$ & 258947 & 7 Brasil & São Paulo & Torre de Pedra & $23015^{\circ} 00^{\prime \prime} \mathrm{S}$ & $48012^{\circ} 00^{\prime \prime}$ & 640 & S.M.Carmello & 3 & 9/30/8 \\
\hline Crotonfloribundus Spreng. & -.- & HRCB & 7179 & 9 Brasil & São Paulo & Tupã & -.- & -.- & -.- & J.E.L.Da Silva & 81 & $10 / 11 / 8$ \\
\hline Croton floribundus Spreng. & -.- & $\mathrm{SP}$ & 43935 & 5 Brasil & São Paulo & Ubatua & $23021^{\prime} 00^{\prime \prime S}$ & $44058^{\prime} 00^{\prime \prime}$ & -.- & C.Smith & 66 & 9/15/3! \\
\hline Croton floribundus Spreng. & Capixinguí & SPF & 98677 & 7 Brasil & São Paulo & Ubatuba & $23021^{\prime} 00^{\prime \prime S}$ & $44058^{\prime} 00^{\prime \prime}$ & -.- & Leite E.C. & 29416 & 11/9/9: \\
\hline Croton floribundus Spreng. & ..- & SPF & 98678 & 8 Brasil & São Paulo & Ubatuba & $23021^{\prime} 00^{\prime \prime S}$ & $44058^{\prime} 00 "$ & ... & Lobo P.C. & 29328 & 11/11/9: \\
\hline Croton floribundus Spreng. & -.- & SPF & 98458 & 8 Brasil & São Paulo & Ubatuba & $23021^{\prime} 00 " \mathrm{~S}$ & $44058^{\prime} 00^{\prime \prime}$ & -.- & De Morais M.D. & 29319 & 11/9/9: \\
\hline Croton floribundus Spreng. & -.- & $\mathrm{SP}$ & 267963 & 3 Brasil & São Paulo & Ubatuba & $23021^{\prime} 00^{\prime \prime S}$ & $44058^{\prime} 00^{\prime \prime}$ & -.- & H.Moreira de Sauza & sn & 5/20/7: \\
\hline Crotonfloribundus Spreng. & -.. & SP & 327730 & 0 Brasil & São Paulo & Ubatuba & $23021^{\prime} 00 " \mathrm{~S}$ & $44058^{\prime} 00^{\prime \prime}$ & -.- & F.C.P.Garcia et al. & 230 & 12/30/8: \\
\hline Croton floribundus Spreng. & .-. & SP & 327731 & 1 Brasil & São Paulo & Ubatuba & $23021^{\prime} 00^{\prime \prime S}$ & $44058^{\prime} 00 "$ & ... & F.C.P.Garcia et al. & 245 & 12/3/8: \\
\hline Croton floribundus Spreng. & -.- & $\mathrm{SP}$ & 327758 & 8 Brasil & São Paulo & Ubatuba & $23021^{\prime} 00^{\prime \prime S}$ & $44058^{\prime} 00^{\prime \prime}$ & -.. & 'Furlan et al. & 571 & 11/5/8: \\
\hline Croton floribundus Spreng. & -.- & $\mathrm{SP}$ & 327757 & 7 Brasil & São Paulo & Ubatuba & $23021^{\prime} 00^{\prime \prime S}$ & $44058^{\prime} 00^{\prime \prime}$ & -.- & "Furlan et al. & 897 & 11/11/9: \\
\hline Croton floribundus Spreng. & -.- & SP & 279774 & 4 Brasil & São Paulo & Ubatuba & $23021^{\prime} 00 " \mathrm{~s}$ & $44058^{\prime} 00^{\prime \prime}$ & -.- & M.D.deMorais et al. & 29319 & 11/9/9: \\
\hline Crotonfloribundus Spreng. & -.- & SP & 279738 & 8 Brasil & São Paulo & Ubatuba & $23021^{\prime} 00 " \mathrm{~s}$ & $44058^{\prime} 00^{\prime \prime}$ & -.- & E.C.Leite et al. & 29416 & 11/9/9: \\
\hline Croton floribundus Spreng. & -.- & SP & 279739 & 9 Brasil & São Paulo & Ubatuba & $23021^{\prime} 00 " \mathrm{~s}$ & $44058^{\prime} 00^{\prime \prime}$ & -. & P.C.Lobo et al & 29328 & 11/11/9. \\
\hline Croton floribundus Spreng. & -.- & UEC & 4687 & 7 Brasil & São Paulo & Ubatuba & $23021^{\prime} 00^{\prime \prime S}$ & $44058^{\prime} 00^{\prime \prime}$ & -.- & P.E. Gibbs et al. & 3463 & $11 / 9 / 71$ \\
\hline Crotonfloribundus Spreng. & $\ldots$ & UEC & 89204 & 4 Brasil & São Paulo & Ubatuba & $23021^{1} 00^{\prime \prime S}$ & $44058^{\prime} 00^{\prime \prime}$ & $\ldots$ & E.C.Leitão et al. & 29415 & 11/11/9: \\
\hline
\end{tabular}


Informação do material botânico nos herbários do gênero Croton

(Continuacão)

\begin{tabular}{|c|c|c|c|c|c|c|c|c|c|c|c|c|}
\hline \multirow{2}{*}{$\begin{array}{l}\text { Espécie } \\
\text { N.científico }\end{array}$} & \multirow[b]{2}{*}{ N. vulgar } & \multicolumn{2}{|c|}{ Herbário } & \multicolumn{3}{|l|}{ Localidade } & \multirow{2}{*}{$\begin{array}{l}\text { Latitude } \\
(\text { (oS.S) }\end{array}$} & \multirow{2}{*}{$\begin{array}{r}\text { Longitude } \\
\text { (os. W) }\end{array}$} & \multirow[b]{2}{*}{ Altitude } & \multicolumn{3}{|l|}{$\begin{array}{l}\text { COLETOR } \\
\end{array}$} \\
\hline & & Sigla & Registro & País & Estado & Município & & & & Nome/número & & ta \\
\hline Croton floribundus Spreng. & $\ldots$ & UEC & & 82285 Brasil & São Paulo & Ubatuba & $230211^{\prime} 00 " \mathrm{~s}$ & $44058^{\prime} 00^{\prime \prime}$ & $-\ldots$ & H.F.Leitão et al. & 34840 & $2 / 6 / 96$ \\
\hline Croton floribundus Spreng. & - & UEC & & 66652 Brasil & São Paulo & Ubatuba & $230211^{\prime} 00^{\prime S} \mathrm{~S}$ & $44058^{\circ} 00^{\prime \prime}$ & -.- & H.M.deSouza & $\mathrm{sn}$ & $5 / 20 / 72$ \\
\hline Croton floribundus Spreng. & -- & UEC & & 67496 Brasil & São Paulo & Ubatuba & $23021^{\prime} 00 " \mathrm{~s}$ & $44058^{\circ} 00^{\prime \prime}$ & -.- & P.C.Lobo et al. & 29328 & $11 / 11 / 93$ \\
\hline Croton floribundus Spreng. & -- & UEC & & 67677 Brasil & São Paulo & Ubatuba & $230211^{\prime} 00 " \mathrm{~s}$ & $44058^{\circ} 00^{\prime \prime}$ & -.- & M.D.deMoraes et al. & 29319 & 11/9/93 \\
\hline Croton floribundus Spreng. & Capixingui & UEC & & 67885 Brasil & São Paulo & Ubatuba & $23021^{\prime} 00 " \mathrm{~S}$ & $44058^{\prime} 00^{\prime \prime}$ & ..- & C.Leite et al. & 29416 & 11/9/93 \\
\hline Croton floribundus Spreng. & -- & UEC & & 74290 Brasil & São Paulo & Ubatuba & $230211^{\prime} 00 " \mathrm{~s}$ & $44058^{\circ} 00^{\prime \prime}$ & --- & S.C.Rossato & 33833 & $11 / 10 / 92$ \\
\hline Croton floribundus Spreng. & -- & HRCB & & 14508 Brasil & São Paulo & Ubatuba & $23021^{\prime} 00 " \mathrm{~s}$ & $44058^{\circ} 00^{\prime \prime}$ & -.- & A.Furlan et al. & 1354 & 11/5/91 \\
\hline Croton floribundus Spreng. & -- & HRCB & & 9776 Brasil & São Paulo & Ubatuba & $23021^{\prime} 00 " \mathrm{~s}$ & $44058^{\prime} 00^{\prime \prime}$ & -.. & F.C.P.Garcia et al. & 230 & $12 / 3 / 88$ \\
\hline Croton floribundus Spreng. & -- & HRCB & & 9791 Brasil & São Paulo & Ubatuba & $230211^{\prime} 00 " \mathrm{~s}$ & $44058^{\circ} 00^{\prime \prime}$ & -.- & F.C.P.Garcia et al. & 245 & $12 / 3 / 88$ \\
\hline Croton floribundus Spreng. & -. & HRСВ & & 31038 Brasil & São Paulo & Ubatuba & $23021^{\prime} 00 " \mathrm{~s}$ & $44058^{\circ} 00^{\prime \prime}$ & -.- & C.S.C.Bencke et al. & 151 & $11 / 29 / 95$ \\
\hline Croton floribundus Spreng. & Capixingui & SPSF & & 28829 Brasil & São Paulo & Vinhedo & $23033^{\prime} 00^{\prime \prime S}$ & $46043^{\prime} 00^{\prime \prime}$ & & 750 J.R. Guillaumon & $\mathrm{sn}$ & $10 / 14 / 01$ \\
\hline Croton floribundus Spreng. & -- & UEC & & 4699 Brasil & São Paulo & Vinhedo & -.. & -.. & -.. & ${ }^{\mathrm{a} F}$.Silva et al. & 8884 & $11 / 23 / 78$ \\
\hline Croton floribundus Spreng. & & NYBG & & 504098 Paraguai & Canendiyú & -.. & $24001^{\prime} 10^{\prime \prime S}$ & $54020^{2} 24 "$ & -.- & Bernadi M. & 18254 & 28/10/1978 \\
\hline Croton lechleri Müell.Arg. & & мо & $* * *$ & Bolívia & Beni & -.- & $15017^{\prime} 00 " \mathrm{~s}$ & $67004^{\circ} 00^{\prime \prime}$ & & 875 D.D.N. Smith et al 1. & & $2 / 1 / 90$ \\
\hline Croton lechleri Müell.Arg. & & мо & $* * *$ & Bolívia & La Paz & -.- & $15058^{\circ} 00^{\prime \prime S}$ & $67037^{\circ} 00^{\prime \prime}$ & & 500 J. C. Solomon 9278 & & $1 / 15 / 83$ \\
\hline Croton lechleri Müell.Arg. & & LPB & $* * *$ & Bolívia & La Paz & -.. & -.. & & & 900 Beck 17803 & & \\
\hline Croton lechleri Müell.Arg. & -- & HUNB & $\mathrm{sn}$ & Bolívia & La Paz & Sud Yungas & $161300 \mathrm{sS}$ & $67047^{\circ} 00^{\prime \prime}$ & & 000 Beck G. & 17803 & $21 / 09 / 1990$ \\
\hline Croton lechleri Müell.Arg. & & мо & $* * *$ & Bolívia & Santa Cruz & ..- & $17037^{\circ} 00^{\prime S S}$ & $63040^{\circ} 00^{\prime \prime}$ & & 400 J.C.Solomon et al. 1 . & & $8 / 24 / 85$ \\
\hline Croton lechleri Müell.Arg. & & мо & $* * *$ & Bolívia & Santa Cruz & 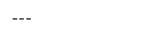 & $17044^{\prime} 00 " \mathrm{~s}$ & $63040^{\circ} 00^{\prime \prime}$ & & 700 J. C. Solomon et al. & & $8 / 28 / 85$ \\
\hline Croton lechleri Müell.Arg. & & мо & $* * *$ & Bolívia & Yungas & -.. & $16013^{\prime} 00 " \mathrm{~s}$ & $67047^{\circ} 00^{\prime \prime}$ & & 00 J.C.Solomon 12552 & & $10 / 21 / 84$ \\
\hline Croton lechleri Müell.Arg. & Sangue-de-grado & UFAC & & 11465 Brasil & Acre & Assis Brasil & $10057^{\prime} 30 " \mathrm{~s}$ & $69034^{\prime} 06^{\prime \prime}$ & & 180 D.C.Daly & 9833 & $00 / 08 / 2141$ \\
\hline Croton lechleri Müell.Arg. & -- & UFAC & & 9721 Brasil & Acre & Brasiléia & $10057^{\prime} 11 \mathrm{ls}$ & $69039^{2} 29^{\prime \prime}$ & & 180 D.C.Daly & 9721 & $00 / 08 / 2140$ \\
\hline Croton lechleri Müell.Arg. & -. & UFAC & & 9155 Brasil & Acre & Plácido Castro & $10018^{\prime} 40^{\prime \prime S}$ & 67031'30" & & 136 C.Dasilva et al. & 570 & $00 / 08 / 2139$ \\
\hline Croton lechleri Müell.Arg. & & $\mathrm{COL}$ & $* * *$ & Colômbia & -.- & -.. & -.. & & -.. & J. Cuatrecasas 11018 & & \\
\hline Croton lechleri Müell.Arg. & & мо & $* * *$ & Equador & -- & -.. & -.. & & & 240 B. Smith 240 & & \\
\hline Croton lechleri Müell.Arg. & & usz & $* * *$ & Equador & -- & -.. & -.. & & -.- & Little \& Campuzano & & \\
\hline Croton lechleri Müell.Arg. & & мо & $* * *$ & Equador & Carchi & -.- & $01006^{\circ} 00^{\prime \prime} \mathrm{N}$ & $78014^{\circ} 00^{\prime \prime}$ & & 500 D.Rubio et al 1049 & & $11 / 16 / 90$ \\
\hline Croton lechleri Müell.Arg. & & мо & $* * *$ & Equador & Carchi & -.- & $01002^{\prime} 00^{\prime \prime N}$ & 78015'00" & & 150 A. Grijalva et al. 474 & & 2/19/93 \\
\hline Croton lechleri Müell.Arg. & & мо & $* * *$ & Equador & Carchi & $\cdots$ & $00055^{\prime} 00 " \mathrm{~N}$ & 78032'00" & & 900 C.Aulestia et al. 748 & & $11 / 22 / 92$ \\
\hline Croton lechleri Müell.Arg. & & NY & $* * *$ & Equador & Esmeralda & LaUnión & $01000^{\circ} 00^{\prime \prime N}$ & 78033'00" & & 425 Beck et al. 2307 & & $7 / 16 / 94$ \\
\hline Croton lechleri Müell.Arg. & & мо & $* * *$ & Equador & Guayas & -.. & $02020^{\circ} 00^{\prime \prime} \mathrm{s}$ & $79050^{\circ} 00^{\prime \prime}$ & & 250 T. Hernández et al. 1 & & $5 / 1 / 93$ \\
\hline Croton lechleri Müell.Arg. & & мо & $* * *$ & Equador & Loja & -.- & $040011^{\prime} 00^{\prime S}$ & 78055'00" & & 100 E.Gudiño et al. 1419 & & 6/20/91 \\
\hline Croton lechleri Müell.Arg. & & мо & $* * *$ & Equador & Loja & -.- & $040011^{\prime} 00^{\prime S}$ & 78055'00" & & 100 E.Gudiño et al. 1420 & & 6/20/91 \\
\hline Croton lechleri Müell.Arg. & & мо & $* * *$ & Equador & Loja & -.- & $0400100 " \mathrm{~s}$ & $78055^{\circ} 00^{\prime \prime}$ & & 100 E.Gudiño et al. 1427 & & 6/20/91 \\
\hline Croton lechleri Müell.Arg. & & мо & $* * *$ & & Moroña-Santiago & -.. & $02035^{\prime} 00 " \mathrm{~s}$ & $78010^{\circ} 00^{\prime \prime}$ & & 150 E.Gudiño et al. 1492 & & $7 / 5 / 91$ \\
\hline Croton lechleri Müell.Arg. & & мо & $* * *$ & Equador & Moroña-Santiago & $\cdots$ & $02047^{\circ} 00^{\prime S} \mathrm{~S}$ & 77036'00" & & 300 R.W.Juwa 85 & & $8 / 22 / 85$ \\
\hline Croton lechleri Müell.Arg. & & мо & $* * *$ & Equador & Moroña-Santiago & -.- & $02032^{\prime} 00^{\prime S} \mathrm{~S}$ & $77054^{\circ} 00^{\prime \prime}$ & & 500 W.Palacios et al 155 & & $1 / 18 / 02$ \\
\hline Croton lechleri Müell.Arg. & & мо & $* * *$ & Equador & Moroña-Santiago & $\ldots$ & $01040^{\circ} 00^{\prime S}$ & $77055^{\circ} 00^{\prime \prime}$ & & 390 E.Gudiño et al. 1608 & & 11/9/91 \\
\hline Croton lechleri Müell.Arg. & & мо & $* * *$ & Equador & Moroña-Santiago & -.. & $01040^{\circ} 00^{\prime S} \mathrm{~s}$ & $77055^{\circ} 00^{\prime \prime}$ & & 890 E.Gudiño et al. 1609 & & 11/9/91 \\
\hline Croton lechleri Müell.Arg. & & мо & $* * *$ & Equador & Moroña-Santiago & $\ldots$ & $01040^{\circ} 00^{\prime S} \mathrm{~S}$ & $77055^{\circ} 00^{\prime \prime}$ & & 900 E.Gudiño et al. 1601 & & $11 / 8 / 91$ \\
\hline
\end{tabular}




\begin{tabular}{|c|c|c|c|c|c|c|c|c|c|c|c|}
\hline \multirow{2}{*}{$\begin{array}{l}\text { Espécie } \\
\text { N.científico }\end{array}$} & \multirow[b]{2}{*}{ N. vulgar } & \multicolumn{2}{|c|}{ Herbário } & \multicolumn{3}{|l|}{ Localidade } & \multirow[b]{2}{*}{$\begin{array}{c}\text { Latitude } \\
\quad\left({ }^{\circ}, S\right) \\
\end{array}$} & \multirow[b]{2}{*}{$\begin{array}{r}\text { Longitude } \\
\left({ }^{\circ} \mathrm{S}, \mathrm{W}\right)\end{array}$} & \multicolumn{2}{|r|}{ COLETOR } & \multirow[b]{2}{*}{ Data } \\
\hline & & Sigla & Registro & País & Estado & Município & & & $\begin{array}{c}\text { Altitude } \\
(\text { manm })\end{array}$ & Nome/número & \\
\hline Croton lechleri Müell.Arg. & & мо & **** & Equador & Moroña-Santiago & --- & $01050^{\prime} 00 " \mathrm{~s}$ & $77055^{\prime} 00^{\prime \prime}$ & & 0 E.Gudiño et al. 1600 & $11 / 7 / 91$ \\
\hline Croton lechleri Müell.Arg. & & мо & **** & Equador & Moroña-Santiago & -.. & $02021^{\prime} 16 " \mathrm{~s}$ & 77o57'29" & & 6 Linder S 1636 & $4 / 14 / 02$ \\
\hline Croton lechleri Müell.Arg. & & мо & $* * *$ & Equador & Moroña-Santiago & -.. & $01056^{\circ} 00^{\prime S} \mathrm{~s}$ & 77059'00" & & 0 E.Gudiño et al. 1597 & $11 / 6 / 91$ \\
\hline Croton lechleri Müell.Arg. & & мо & $* * *$ & Equador & Moroña-Santiago & -.. & $01056^{\circ} 00^{\prime \prime} \mathrm{s}$ & $77059^{\prime} 00^{\prime \prime}$ & & 0 E.Gudiño et al. 1598 & $11 / 6 / 91$ \\
\hline Croton lechleri Müell.Arg. & & мо & $* * *$ & Equador & Moroña-Santiago & -.. & $01040^{\prime} 00^{\prime \prime S}$ & 78002'00" & & 5 J.Caranqui et al. 813 & $8 / 26 / 02$ \\
\hline Croton lechleri Müell.Arg. & & мо & **** & Equador & Moroña-Santiago & $\ldots$ & $01035^{\prime} 00 " \mathrm{~s}$ & $78005^{\circ} 00^{\prime \prime}$ & 1060 & 0 E.Gudiño et al. 1511 & $7 / 6 / 91$ \\
\hline Croton lechleri Müell.Arg. & & мо & $* * *$ & Equador & Moroña-Santiago & -.. & $02010^{\prime} 00^{\prime S} \mathrm{~s}$ & $78005^{\prime} 00^{\prime \prime}$ & & 0 E.Gudiño et al.1584 & $11 / 5 / 91$ \\
\hline Croton lechleri Müell.Arg. & & мо & $* * *$ & Equador & Moroña-Santiago & -.- & $02010^{\prime} 00^{\prime \prime S}$ & $78005^{\prime} 00^{\prime \prime}$ & & 0 E.Gudiño et al.1585 & $11 / 5 / 91$ \\
\hline Croton lechleri Müell.Arg. & & мо & *** & Equador & Moroña-Santiago & $\ldots$ & $02010^{\prime} 00^{\prime S} \mathrm{~s}$ & $78005^{\prime} 00^{\prime \prime}$ & & 0 E.Gudiño et al. 1594 & $11 / 5 / 91$ \\
\hline Croton lechleri Müell.Arg. & & мо & **** & Equador & Moroña-Santiago & $\ldots$ & $02020^{\prime} 00^{\prime \prime} \mathrm{s}$ & $78005^{\prime} 00^{\prime \prime}$ & 1255 & 5 Gudiño et al. 1579 & 11/4/91 \\
\hline Croton lechleri Müell.Arg. & & мо & $* * *$ & Equador & Moroña-Santiago & ..- & 02018 '59"s & $7800758 "$ & 1070 & 0 P.E.Berry 7622 & $3 / 16 / 01$ \\
\hline Croton lechleri Müell.Arg. & & NY & $* * *$ & Equador & Moroña-Santiago & $\ldots$ & $02030^{\circ} 00^{\prime \prime} \mathrm{s}$ & $78008^{\prime} 00^{\prime \prime}$ & & 0 P.Gomez 1989 & $1 / 20 / 85$ \\
\hline Croton lechleri Müell.Arg. & & мо & $* * *$ & Equador & Moroña-Santiago & $\ldots$ & $02035^{\prime} 00 " \mathrm{~s}$ & $78010^{\prime} 00^{\prime \prime}$ & 1200 & 0 E.Gudiño et al. 1489 & $7 / 5 / 91$ \\
\hline Croton lechleri Müell.Arg. & & мо & $* * *$ & Equador & Moroña-Santiago & -.. & $02016^{\prime} 00 " \mathrm{~s}$ & 78011'00" & & $6 \mathrm{~J}$. Caranqui et al. 746 & $8 / 22 / 02$ \\
\hline Croton lechleri Müell.Arg. & & мо & **** & Equador & Moroña-Santiago & -.. & $02035^{\prime} 00 " \mathrm{~s}$ & $78015^{\circ} 00^{\prime \prime}$ & 1100 & 0 E.Gudiño et al. 1487 & $7 / 5 / 91$ \\
\hline Croton lechleri Müell.Arg. & & мо & $* * *$ & Equador & Moroña-Santiago & $\ldots$ & $02040^{\circ} 00^{\prime \prime S}$ & $78020^{\circ} 00^{\prime \prime}$ & 1600 & 0 E.Gudiño et al. 1468 & $7 / 4 / 91$ \\
\hline Croton lechleri Müell.Arg. & & мо & $* * *$ & Equador & Moroña-Santiago & -.. & $02036^{\prime} 00 " \mathrm{~s}$ & $78028^{\circ} 00^{\prime \prime}$ & 1750 & 0 C.Cerón 13762 & $3 / 24 / 91$ \\
\hline Croton lechleri Müell.Arg. & & $\mathrm{NY}$ & $* * *$ & Equador & Moroña-Santiago & -.. & ..- & & & 0 L. Anananch 108 & $8 / 23 / 85$ \\
\hline Croton lechleri Müell.Arg. & & $\mathrm{NY}$ & **** & Equador & Moroña-Santiago & $\ldots$ & -.. & & & 0 P.W. Kasent 18 & $8 / 13 / 85$ \\
\hline Croton lechleri Müell.Arg. & & мо & $* * *$ & Equador & Napo & Yasuni & $00050^{\prime} 00^{\prime S}$ & $76014^{\prime} 00^{\prime \prime}$ & & 0 M.Aulestia et al. 1559 & $1 / 15 / 94$ \\
\hline Croton lechleri Müell.Arg. & & мо & $* * *$ & Equador & Napo & Yasuni & $00051^{\prime} 00 " \mathrm{~s}$ & $76015^{\prime} 00^{\prime \prime}$ & & 0 A.Dik 1201 & 3/25/94 \\
\hline Croton lechleri Müell.Arg. & & мо & *** & Equador & Napo & Yasuni & $00049^{\prime} 00 " \mathrm{~s}$ & $76020^{\circ} 00^{\prime \prime}$ & & 0 A.Dik 1030 & 2/1/94 \\
\hline Croton lechleri Müell.Arg. & & мо & $* * *$ & Equador & Napo & Yasuni & $00044^{\prime} 00^{\prime \prime S}$ & $76028^{\prime} 00^{\prime \prime}$ & -.- & A.Dick 420 & 9/13/93 \\
\hline Croton lechleri Müell.Arg. & & мо & $* * *$ & Equador & Napo & Yasuni & $00045^{\prime} 00 \mathrm{~s}$ & $76030^{\circ} 00^{\prime \prime}$ & & 0 A Dik 271 & 9/5/91 \\
\hline Croton lechleri Müell.Arg. & & мо & $* * *$ & Equador & Napo & Yasuni & $00047^{\prime} 00 " \mathrm{~s}$ & $76030^{\circ} 00^{\prime \prime}$ & & 0 M.Aulestia et al. 491 & $8 / 1 / 93$ \\
\hline Croton lechleri Müell.Arg. & & мо & $* * *$ & Equador & Napo & Yasuni & $00047^{\prime} 00 " \mathrm{~s}$ & $76030^{\circ} 00^{\prime \prime}$ & & 0 M.Aulestia et al. 473 & 9/1/93 \\
\hline Croton lechleri Müell.Arg. & & мо & **** & Equador & Napo & Yasuni & $00029^{\prime} 00 " \mathrm{~s}$ & 76034'00" & & 0 J.Zuleta 118 & $1 / 31 / 93$ \\
\hline Croton lechleri Müell.Arg. & & мо & *** & Equador & Napo & Yasuni & $00025^{\prime} 00 " \mathrm{~s}$ & 76037'00" & & 0 E.Gudiño et al. 2268 & 2/20/93 \\
\hline Croton lechleri Müell.Arg. & & мо & $* * *$ & Equador & Napo & Yasuni & $00025^{\prime} 00 \mathrm{~s}$ & 76037'00" & & 0 E.Gudiño et al. 2301 & 2/21/93 \\
\hline Croton lechleri Müell.Arg. & & мо & $* * *$ & Equador & Napo & -.. & $00030^{\prime} 00^{\prime \prime} \mathrm{s}$ & $77010^{\prime} 00^{\prime \prime}$ & & 5 E.Gudiño et al.1572 & 10/23/91 \\
\hline Croton lechleri Müell.Arg. & & мо & *** & Equador & Napo & -.- & $00030^{\prime} 00^{\prime \prime S}$ & $77010^{\prime} 00^{\prime \prime}$ & 1180 & 0 E.Gudiño et al.1571 & 10/22/91 \\
\hline Croton lechleri Müell.Arg. & & мо & $* * *$ & Equador & Napo & ... & $00040^{\prime} 00 " \mathrm{~s}$ & $77020^{\circ} 00^{\prime \prime}$ & & 0 E.Gudiño et al. 1543 & $7 / 8 / 91$ \\
\hline Croton lechleri Müell.Arg. & & мо & *** & Equador & Napo & -.. & 00043'00"s & $77025^{\prime} 00^{\prime \prime}$ & 1150 & 0 E.Gudiño et al.1577 & 10/26/91 \\
\hline Croton lechleri Müell.Arg. & & мо & *** & Equador & Napo & Jatun Sacha & $00055^{\prime} 00 " \mathrm{~s}$ & $77025^{\prime} 00^{\prime \prime}$ & & 0 D.Neill et al. 7755 & 6/29/87 \\
\hline Croton lechleri Müell.Arg. & & мо & $* * *$ & Equador & Napo & -.. & $00045^{\prime} 00 " \mathrm{~s}$ & $77026^{\circ} 00^{\prime \prime}$ & & 5 E.Gudiño et al.1573 & 10/23/91 \\
\hline Croton lechleri Müell.Arg. & & мо & **** & Equador & Napo & Sumaco & $00045^{\prime} 00 " \mathrm{~s}$ & $77028^{\prime} 00^{\prime \prime}$ & & 0 F.Hurtado et al. 2401 & $7 / 14 / 89$ \\
\hline Croton lechleri Müell.Arg. & & мо & *** & Equador & Napo & ... & $00044^{\prime} 00^{\prime S} \mathrm{~s}$ & $77029^{\prime} 00^{\prime \prime}$ & & 0 E.Gudiño et al.1575 & 10/24/91 \\
\hline Croton lechleri Müell.Arg. & & мо & $* * *$ & Equador & Napo & -.. & $00008^{\prime} 00 " \mathrm{~s}$ & $77030^{\circ} 00^{\prime \prime}$ & 1450 & 0 W.Palacios 6109 & 10/6/90 \\
\hline Croton lechleri Müell.Arg. & & мо & $* * *$ & Equador & Napo & -.. & $00008^{\prime} 00 " \mathrm{~s}$ & $77030^{\circ} 00^{\prime \prime}$ & 1450 & 0 W. Palacios 6121 & $10 / 6 / 90$ \\
\hline Croton lechleri Müell.Arg. & & мо & $* * * *$ & Equador & Napo & $\ldots$ & $00025^{\prime} 00 \mathrm{NS}$ & $77030^{\circ} 00^{\prime \prime}$ & 1300 & 0 E.Gudiño et al.1530 & $7 / 8 / 91$ \\
\hline
\end{tabular}




\begin{tabular}{|c|c|c|c|c|c|c|c|c|c|c|c|}
\hline \multirow{2}{*}{$\begin{array}{l}\text { Espécie } \\
\text { N.científico }\end{array}$} & \multirow[b]{2}{*}{ N. vulgar } & \multicolumn{2}{|c|}{ Herbário } & \multicolumn{3}{|l|}{ Localidade } & \multirow[b]{2}{*}{$\begin{array}{c}\text { Latitude } \\
\quad\left({ }^{\circ}, S\right) \\
\end{array}$} & \multirow[b]{2}{*}{$\begin{array}{r}\text { Longitude } \\
\left({ }^{\circ} \mathrm{S}, \mathrm{W}\right)\end{array}$} & \multicolumn{2}{|r|}{ COLETOR } & \multirow[b]{2}{*}{ Data } \\
\hline & & Sigla & Registro & País & Estado & Município & & & $\begin{array}{c}\text { Altitude } \\
(\text { manm })\end{array}$ & Nome/número & \\
\hline Croton lechleri Müell.Arg. & & мо & **** & Equador & Napo & --- & $00025^{\prime} 00 " \mathrm{~s}$ & $77030^{\circ} 00^{\prime \prime}$ & & 0 E.Gudiño et al. 1532 & $7 / 8 / 91$ \\
\hline Croton lechleri Müell.Arg. & & мо & **** & Equador & Napo & -.. & $00025^{\prime} 00 " \mathrm{~s}$ & $77030^{\prime} 00^{\prime \prime}$ & & 0 E.Gudiño et al. 1537 & $7 / 8 / 91$ \\
\hline Croton lechleri Müell.Arg. & & мо & $* * *$ & Equador & Napo & -.. & $00025^{\prime} 00 \mathrm{~s}$ & $77030^{\circ} 00^{\prime \prime}$ & 1300 & 0 E.Gudiño et al. 1535 & $7 / 8 / 91$ \\
\hline Croton lechleri Müell.Arg. & & мо & $* * *$ & Equador & Napo & -.. & $00043^{\prime} 00 " \mathrm{~s}$ & 77031'00" & 1020 & 0 E.Gudiño et al. 1574 & 10/23/91 \\
\hline Croton lechleri Müell.Arg. & & мо & $* * *$ & Equador & Napo & -.. & $00044^{\prime} 00 " \mathrm{~s}$ & $77033^{\prime} 00^{\prime \prime}$ & 915 & 5 E.Gudiño et al.1576 & 10/26/91 \\
\hline Croton lechleri Müell.Arg. & & мо & **** & Equador & Napo & Sumaco & 00038 '56"s & $77035^{\prime} 49^{\prime \prime}$ & 1550 & 0 A.Alvarez et al. 2077 & 4/29/97 \\
\hline Croton lechleri Müell.Arg. & & мо & $* * *$ & Equador & Napo & Sumaco & 00038 '56"S & $77035^{\prime} 49^{\prime \prime}$ & 1580 & 0 A Alvarez et al. 1902 & 4/23/97 \\
\hline Croton lechleri Müell.Arg. & & мо & $* * *$ & Equador & Napo & Sumaco & $00042^{\prime} 00 " \mathrm{~s}$ & $77036^{\prime} 00^{\prime \prime}$ & 1000 & 0 C.Cerón et al.7419 & $8 / 21 / 89$ \\
\hline Croton lechleri Müell.Arg. & & мо & *** & Equador & Napo & Sumaco & $00043^{\prime} 00 " \mathrm{~s}$ & $77036^{\circ} 00^{\prime \prime}$ & 1200 & 0 F.Hurtado et al. 151 & $10 / 7 / 88$ \\
\hline Croton lechleri Müell.Arg. & & мо & $* * *$ & Equador & Napo & Jatun Sacha & $01004^{\prime} 00^{\prime S}$ & $77036^{\circ} 00^{\prime \prime}$ & 450 & 0 D.Cuamacás 56 & $2 / 10 / 03$ \\
\hline Croton lechleri Müell.Arg. & & мо & $* * *$ & Equador & Napo & Sumaco & $00045^{\circ} 00 \mathrm{~s}$ & $77038^{\prime} 00^{\prime \prime}$ & 1200 & 0 C.Cerón et al. 6536 & $4 / 21 / 89$ \\
\hline Croton lechleri Müell.Arg. & & мо & $* * *$ & Equador & Napo & Jatun Sacha & $01005^{\prime} 00 " \mathrm{~s}$ & $77039^{\prime} 00^{\prime \prime}$ & & $0 \mathrm{~J}$. Zuleta 62 & $12 / 15 / 92$ \\
\hline Croton lechleri Müell.Arg. & & мо & $* * *$ & Equador & Napo & $\ldots$ & $00050^{\prime} 00^{\prime \prime S}$ & $77040^{\circ} 00^{\prime \prime}$ & 650 & 0 E.Gudiño et al.1540 & $7 / 8 / 91$ \\
\hline Croton lechleri Müell.Arg. & & мо & $* * *$ & Equador & Napo & Sumaco & $00041^{\prime} 00 " \mathrm{~s}$ & $77041^{\prime} 00^{\prime \prime}$ & 1100 & 0 F.Hurtado et al. 1709 & 2/22/89 \\
\hline Croton lechleri Müell.Arg. & & мо & **** & Equador & Napo & -.. & $00050^{\circ} 00^{\prime \prime} \mathrm{s}$ & $77045^{\circ} 00^{\prime \prime}$ & 1200 & 0 E.Gudiño et al. 1228 & $1 / 15 / 91$ \\
\hline Croton lechleri Müell.Arg. & & мо & $* * *$ & Equador & Napo & $\ldots$ & $00050^{\circ} 00^{\prime \prime s}$ & $77045^{\prime} 00^{\prime \prime}$ & 1200 & 0 E.Gudiño et al. 1229 & $1 / 15 / 91$ \\
\hline Croton lechleri Müell.Arg. & & мо & $* * *$ & Equador & Napo & -.. & $00050^{\prime} 00^{\prime \prime S}$ & $77045^{\prime} 00^{\prime \prime}$ & 1200 & 0 E.Gudiño et al. 1230 & $1 / 15 / 91$ \\
\hline Croton lechleri Müell.Arg. & & мо & $* * *$ & Equador & Napo & -.. & $00050^{\prime} 00^{\prime \prime S}$ & $77045^{\prime} 00^{\prime \prime}$ & 1200 & 0 E.Gudiño et al. 1231 & $1 / 15 / 91$ \\
\hline Croton lechleri Müell.Arg. & & мо & **** & Equador & Napo & $\ldots$ & $00050^{\circ} 00^{\prime \prime} \mathrm{s}$ & $77045^{\prime} 00^{\prime \prime}$ & 1200 & 0 E.Gudiño et al. 1232 & $1 / 15 / 91$ \\
\hline Croton lechleri Müell.Arg. & & мо & $* * *$ & Equador & Napo & ... & $00050^{\prime} 00^{\prime S}$ & $77045^{\prime} 00^{\prime \prime}$ & 1200 & 0 E.Gudiño et al. 1233 & $1 / 15 / 91$ \\
\hline Croton lechleri Müell.Arg. & & мо & $* * *$ & Equador & Napo & -.. & $00040^{\prime} 00^{\prime \prime S}$ & $77050^{\circ} 00^{\prime \prime}$ & & 0 E.Gudiño et al.1237 & $1 / 15 / 91$ \\
\hline Croton lechleri Müell.Arg. & & мо & *** & Equador & Napo & -.- & $00040^{\circ} 00^{\prime S} \mathrm{~s}$ & $77050^{\circ} 00^{\prime \prime}$ & 800 & 0 E.Gudiño et al. 1238 & $1 / 15 / 91$ \\
\hline Croton lechleri Müell.Arg. & & мо & $* * *$ & Equador & Napo & -.- & $00040^{\prime} 00^{\prime \prime S}$ & $77050^{\circ} 00^{\prime \prime}$ & 800 & 0 E.Gudiño et al. 1234 & $1 / 15 / 91$ \\
\hline Croton lechleri Müell.Arg. & & мо & $* * *$ & Equador & Napo & ... & $00040^{\prime} 00^{\prime S} \mathrm{~s}$ & $77050^{\circ} 00^{\prime \prime}$ & & 0 E.Gudiño et al. 1235 & $1 / 15 / 91$ \\
\hline Croton lechleri Müell.Arg. & & мо & $* * *$ & Equador & Napo & ... & $00040^{\prime} 00^{\prime S} \mathrm{~s}$ & $77050^{\circ} 00^{\prime \prime}$ & & 0 E.Gudiño et al. 1236 & $1 / 15 / 91$ \\
\hline Croton lechleri Müell.Arg. & & мо & $* * *$ & Equador & Napo & $\ldots$ & $00040^{\circ} 00^{\prime \prime S}$ & $77050^{\circ} 00^{\prime \prime}$ & & 0 E.Gudiño et al. 1239 & $1 / 15 / 91$ \\
\hline Croton lechleri Müell.Arg. & & мо & **** & Equador & Napo & $\ldots$ & $00045^{\prime} 00 " \mathrm{~s}$ & $77050^{\circ} 00^{\prime \prime}$ & & 0 E.Gudiño et al. 1223 & $1 / 15 / 91$ \\
\hline Croton lechleri Müell.Arg. & & мо & *** & Equador & Napo & ... & $00045^{\prime} 00{ }^{\prime S}$ & $77050^{\circ} 00^{\prime \prime}$ & & 0 E.Gudiño et al. 1224 & $1 / 15 / 91$ \\
\hline Croton lechleri Müell.Arg. & & мо & $* * *$ & Equador & Napo & ..- & $00045^{\prime} 00 \mathrm{~s}$ & $77050^{\circ} 00^{\prime \prime}$ & & 0 E.Gudiño et al. 1225 & $1 / 15 / 91$ \\
\hline Croton lechleri Müell.Arg. & & мо & $* * *$ & Equador & Napo & -.. & $00045^{\prime} 00 " \mathrm{~s}$ & $77050^{\circ} 00^{\prime \prime}$ & & 0 E.Gudiño et al. 1226 & $1 / 15 / 91$ \\
\hline Croton lechleri Müell.Arg. & & мо & *** & Equador & Napo & -.- & $00045^{\prime} 00 " \mathrm{~s}$ & $77050^{\circ} 00^{\prime \prime}$ & & 0 E.Gudiñoet al. 1227 & $1 / 15 / 91$ \\
\hline Croton lechleri Müell.Arg. & & мо & **** & Equador & Napo & $\ldots$ & $00045^{\prime} 00 " \mathrm{~s}$ & $77050^{\circ} 00^{\prime \prime}$ & & 0 E.Gudiño et al. 1222 & $1 / 15 / 91$ \\
\hline Croton lechleri Müell.Arg. & & мо & *** & Equador & Napo & -.. & $00045^{\prime} 00 " \mathrm{~s}$ & $77050^{\circ} 00^{\prime \prime}$ & 1200 & 0 S.Espinoza et al. 756 & $8 / 6 / 91$ \\
\hline Croton lechleri Müell.Arg. & & мо & *** & Equador & Napo & -.- & $00045^{\prime} 00 " \mathrm{~s}$ & $77050^{\circ} 00^{\prime \prime}$ & 1200 & 0 S.Espinoza et al. 757 & $8 / 6 / 91$ \\
\hline Croton lechleri Müell.Arg. & & мо & $* * *$ & Equador & Napo & -.. & $00045^{\prime} 00 " \mathrm{~s}$ & $77050^{\circ} 00^{\prime \prime}$ & 1200 & 0 S.Espinoza et al. 758 & $8 / 6 / 91$ \\
\hline Croton lechleri Müell.Arg. & & мо & **** & Equador & Napo & $\ldots$ & $00045^{\prime} 00 " \mathrm{~s}$ & $77050^{\circ} 00^{\prime \prime}$ & 1200 & 0 S.Espinoza et al. 759 & 8/6/91 \\
\hline Croton lechleri Müell.Arg. & & мо & *** & Equador & Napo & ... & $00045^{\prime} 00 \mathrm{~s}$ & $77050^{\circ} 00^{\prime \prime}$ & 1200 & 0 S.Espinoza et al. 760 & 8/6/91 \\
\hline Croton lechleri Müell.Arg. & & мо & $* * *$ & Equador & Napo & -.. & $00045^{\prime} 00 " \mathrm{~s}$ & $77050^{\circ} 00^{\prime \prime}$ & 1200 & 0 S.Espinoza et al. 761 & $8 / 6 / 91$ \\
\hline Croton lechleri Müell.Arg. & & мо & $* * *$ & Equador & Napo & -.. & $00045^{\prime} 00 " \mathrm{~s}$ & $77050^{\circ} 00^{\prime \prime}$ & 1200 & 0 S.Espinoza et al. 763 & $8 / 6 / 91$ \\
\hline Croton lechleri Müell.Arg. & & мо & $* * * *$ & Equador & Napo & $\ldots$ & $00045^{\prime} 00 \mathrm{~s} \mathrm{~S}$ & $77050^{\circ} 00^{\prime \prime}$ & 1200 & 0 S.Espinoza et al. 764 & $8 / 6 / 91$ \\
\hline
\end{tabular}




\begin{tabular}{|c|c|c|c|c|c|c|c|c|c|c|c|}
\hline \multirow{2}{*}{$\begin{array}{l}\text { Espécie } \\
\text { N.científico }\end{array}$} & \multirow[b]{2}{*}{ N. vulgar } & \multicolumn{2}{|c|}{ Herbário } & \multicolumn{3}{|l|}{ Localidade } & \multirow[b]{2}{*}{ 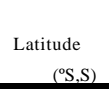 } & \multirow[b]{2}{*}{$\begin{array}{r}\text { Longitude } \\
\left({ }^{\circ} \mathrm{S}, \mathrm{W}\right) \\
\end{array}$} & \multicolumn{2}{|r|}{ COLETOR } & \multirow[b]{2}{*}{ Data } \\
\hline & & Sigla & Registro & País & Estado & Município & & & $\begin{array}{l}\text { Altitude } \\
\text { (manm) }\end{array}$ & Nome/número & \\
\hline Crotonlechleri Müell.Arg. & & мо & ***** & Equador & Napo & - & $00045^{\circ} 00^{\prime \prime S}$ & $77050^{\circ} 00^{\prime \prime}$ & & o S.Espinoza et al. 765 & $8 / 6 / 9$ \\
\hline Crotonlechleri Müell.Arg. & & мо & $* * *$ & Equador & Napo & -- & $00045^{\prime} 00^{\prime \prime} \mathrm{s}$ & $77050^{\circ} 00^{\prime \prime}$ & & 0 S.Espinoza et al. 768 & 9/14/9 \\
\hline Crotonlechleri Müell.Arg. & & мо & *** & Equador & Napo & -_ & $00050^{\circ} 00^{\prime \prime} \mathrm{s}$ & $77050^{\circ} 00^{\prime \prime}$ & 900 & 0 S. Espinoza et al. 770 & $10 / 12 / 9$ \\
\hline Crotonlechleri Müell.Arg. & & мо & $* * * *$ & Equador & Napo & -- & $00050^{\circ} 00^{\prime \prime} \mathrm{S}$ & $77050^{\circ} 00^{\prime \prime}$ & 1150 & 50 E.Gudiño et al. 1570 & $11 / 20 / 9$ \\
\hline Croton lechleri Müell.Arg. & & мо & $* * *$ & Equador & Napo & -- & $01010^{\circ} 00^{\prime \prime} \mathrm{s}$ & $77050^{\circ} 00^{\prime \prime}$ & 1240 & 40 E.Gudiño et al. 1495 & $6 / 6 / 9$ \\
\hline Crotonlechleri Müell.Arg. & & мо & $* * *$ & Equador & Napo & - & $01010^{\circ} 00^{\prime \prime S}$ & $77050^{\circ} 00^{\prime \prime}$ & 1180 & 30 E.Gudiño et al. 1494 & $7 / 6 / 9$ \\
\hline Crotonlechleri Müell.Arg. & & мо & $* * *$ & Equador & Napo & -- & $00055^{\circ} 00^{\prime \prime} \mathrm{s}$ & $77055^{\prime} 00^{\prime \prime}$ & & 0 S.Espinoza et al. 767 & $8 / 28 / 9$ \\
\hline Crotonlechleri Müell.Arg. & & мо & **** & Equador & Napo & -_- & $01010^{\prime} 00^{\prime \prime S}$ & $77055^{\prime} 00^{\prime \prime}$ & 950 & 0 E.Gudiño et al. 1455 & $7 / 7 / 9$ \\
\hline Crotonlechleri Müell.Arg. & & мо & $* * *$ & Equador & Napo & - & $01 " 15^{\prime} 00^{\prime \prime S}$ & $77055^{\prime} 00^{\prime \prime}$ & 900 & 0 E. Gudiño et al.1216 & $1 / 4 / 9$ \\
\hline Crotonlechleri Müell.Arg. & & мо & ***** & Equador & Napo & -- & $01 " 15^{\prime} 00^{\prime S} \mathrm{~S}$ & $77055^{\prime} 00^{\prime \prime}$ & 900 & 0 E.Gudiño et al. 1219 & $1 / 14 / 9$ \\
\hline Crotonlechleri Müell.Arg. & & мо & ***** & Equador & Napo & -- & $01 " 15^{\prime} 00^{\prime S} \mathrm{~s}$ & $77055^{\prime} 00^{\prime \prime}$ & 950 & 0 E.Gudiño et al 1527 & $1 / 7 / 9$ \\
\hline Crotonlechleri Müell.Arg. & & $\mathrm{AAU}$ & $* * *$ & Equador & Napo & - & -.- & & 1970 & 70 O.Roth 35719 & $8 / 8 / 81$ \\
\hline Crotonlechleri Müell.Arg. & & мо & *** & Equador & Napo & Jatun Sacha & -.- & & ... & C.Cerón 19089. & 6/11/9: \\
\hline Croton lechleri Müell.Arg. & & мо & ${ }^{* * * *}$ & Equador & Pastaza & -- & $02031^{\prime} 00 " \mathrm{~s}$ & $76048^{\prime} 00^{\prime \prime}$ & & 5 C.Cerón et al. 4342 & $7 / 15 / 8:$ \\
\hline Croton lechleri Müell.Arg. & & мо & $* * *$ & Equador & Pastaza & Kapawi & $02031^{\prime} 00^{\prime \prime S}$ & $76048^{\prime} 00^{\prime \prime}$ & 235 & 5 W.H.Lewis et al. 14060 & $7 / 25 / 8^{\prime}$ \\
\hline Crotonlechleri Müell.Arg. & & мо & $* * *$ & Equador & Pastaza & Kapawi & $02031^{\prime} 00 " \mathrm{~s}$ & $76048^{\prime} 00^{\prime \prime}$ & 235 & 5 W.H.Lewis et al. 13941 & $7 / 25 / 8$ \\
\hline Crotonlechleri Müell.Arg. & & мо & *** & Equador & Pastaza & -. & $01030^{\circ} 00^{\prime \prime} \mathrm{s}$ & $77030^{\circ} 00^{\prime \prime}$ & 500 & 0 E.Gudiño 1345 & $2 / 20 / 9$ \\
\hline Crotonlechleri Müell.Arg. & & мо & **** & Equador & Pastaza & -- & $01^{115^{\prime} 00^{\prime} \mathrm{S}}$ & $77050^{\circ} 00^{\prime \prime}$ & 1000 & 0 E.Gudiño et al. 1214 & $1 / 14 / 9$ \\
\hline Crotonlechleri Müell.Arg. & & мо & **** & Equador & Pastaza & - & $01 " 15^{\prime} 00^{\prime \prime S}$ & $77050^{\circ} 00^{\prime \prime}$ & 800 & 0 V. Zak 1215 & $1 / 14 / 9$ \\
\hline Crotonlechleri Müell.Arg. & & мо & $* * *$ & Equador & Pastaza & - & $01030^{\circ} 00^{\prime \prime S}$ & $7705457 "$ & 800 & 0 E.Gudiño 450 & $7 / 4 / 91$ \\
\hline Croton lechleri Müell.Arg. & & мо & ${ }^{* * * *}$ & Equador & Pastaza & -- & $01020^{\circ} 00^{\prime \prime} \mathrm{s}$ & $77055^{\prime} 00^{\prime \prime}$ & 1000 & 0 E.Gudiño et al 1221 & $1 / 14 / 9$ \\
\hline Crotonlechleri Müell.Arg. & & мо & **** & Equador & Pastaza & - & $01020^{\circ} 00^{\prime \prime} \mathrm{s}$ & $77055^{\prime} 00^{\prime \prime}$ & 1200 & 0 E.Gudiño et al. 1464 & $7 / 7 / 9$ \\
\hline Crotonlechleri Müell.Arg. & & мо & **** & Equador & Pastaza & - & $01020^{\circ} 00^{\prime \prime} \mathrm{S}$ & $77055^{\prime} 00^{\prime \prime}$ & 1200 & 0 E.Gudiño et al. 1457 & $7 / 7 / 9$ \\
\hline Crotonlechleri Müell.Arg. & & мо & *** & Equador & Pastaza & -_- & $01020^{\circ} 00^{\prime \prime} \mathrm{S}$ & $77055^{\prime} 00^{\prime \prime}$ & 1200 & 0 E.Gudiño et al. 1462 & $7 / 7 / 9$ \\
\hline Croton lechleri Müell.Arg. & & BWC & $* * *$ & Equador & Pastaza & -- & $01030^{\circ} 00^{\prime \prime} \mathrm{s}$ & $77056^{\circ} 00^{\prime \prime}$ & 1040 & 40 J.Caranqui et al. 395 & $2 / 16 / 0$ \\
\hline Crotonlechleri Müell.Arg. & & мо & **** & Equador & Pastaza & - & $01040^{\circ} 00^{\prime \prime} \mathrm{S}$ & $78000^{\circ} 00^{\prime \prime}$ & 1060 & 50 E.Gudiño et al. 1497 & $7 / 6 / 9$ \\
\hline Croton lechleri Müell.Arg. & & мо & **** & Equador & Pastaza & - & $0102700 " \mathrm{~S}$ & $78006^{\circ} 00^{\prime \prime}$ & 1100 & 0 M.Baker et al. 5602 & 3/5/8: \\
\hline Crotonlechleri Müell.Arg. & & мо & **** & Equador & Pastaza & -- & $01027^{\prime} 00 " \mathrm{~s}$ & $78006^{\circ} 00^{\prime \prime}$ & 1100 & 0 N.David 5822 & 2/27/8: \\
\hline Croton lechleri Müell.Arg. & & мо & $* * *$ & Equador & Pastaza & -- & $01027^{\prime} 00 " \mathrm{~s}$ & $78006^{\circ} 00^{\prime \prime}$ & 1300 & $00 \mathrm{~J}$. Zaruma et al. 09 & 2/27/8: \\
\hline Croton lechleri Müell.Arg. & & мо & $* * * *$ & Equador & Sucumbios & - & $00030^{\circ} 00^{\prime \prime} \mathrm{S}$ & $76026^{\prime} 00^{\prime \prime}$ & 200 & 0 J.L.Clark et al. 1103 & 6/9/9: \\
\hline Croton lechleri Müell.Arg. & & мо & **** & Equador & Sucumbios & - & $00005^{\circ} 00^{\prime \prime} \mathrm{s}$ & $76040^{\circ} 00^{\prime \prime}$ & 450 & ;0 E.Gudiño et al. 1554 & $7 / 8 / 8$ \\
\hline Crotonlechleri Müell.Arg. & & мо & **** & Equador & Sucumbios & -- & $00005^{\prime} 00^{\prime \prime} \mathrm{s}$ & $76040^{\circ} 00^{\prime \prime}$ & 450 & 0 E.Gudiño et al. 1551 & $7 / 8 / 9$ \\
\hline Croton lechleri Müell.Arg. & & мо & $* * *$ & Equador & Sucumbios & -- & $00005^{\circ} 00^{\prime \prime} \mathrm{s}$ & $76040^{\circ} 00^{\prime \prime}$ & 450 & 0 E.Gudiño et al. 1549 & $7 / 8 / 9$ \\
\hline Crotonlechleri Müell.Arg. & & мо & $* * * *$ & Equador & Sucumbios & - & $00002^{\prime} 00^{\prime \prime S}$ & $76042^{\prime} 00^{\prime \prime}$ & 250 & 0 C.Cerón 185 & $2 / 5 / 8$ \\
\hline Crotonlechleri Müell.Arg. & & мо & $* * * *$ & Equador & Sucumbios & - & $00003^{\prime} 00^{\prime \prime S}$ & $77020^{\circ} 00^{\prime \prime}$ & 515 & 5 E.Gudiño et al. 569 & $10 / 17 / 9$ \\
\hline Crotonlechleri Müell.Arg. & & мо & $* * *$ & Equador & Sucumbios & -- & $00005^{\prime} 00^{\prime \prime} \mathrm{N}$ & $77020^{\circ} 00^{\prime \prime}$ & 600 & 0 S.Espinoza 771 & $10 / 15 / 9$ \\
\hline Croton lechleri Müell.Arg. & & мо & ${ }^{* * * *}$ & Equador & Sucumbios & -- & $00005^{\circ} 00^{\prime \prime} \mathrm{N}$ & $77020^{\circ} 00^{\prime \prime}$ & 600 & 0 S.Espinoza 772 & $10 / 15 / 9$ \\
\hline Crotonlechleri Müell.Arg. & & MO & $* * * *$ & Equador & Sucumbios & -- & $0000100 " \mathrm{~s}$ & $77025^{\prime} 00^{\prime \prime}$ & 1125 & 25 E.Gudiño et al. 1556 & $7 / 10 / 9$ \\
\hline
\end{tabular}




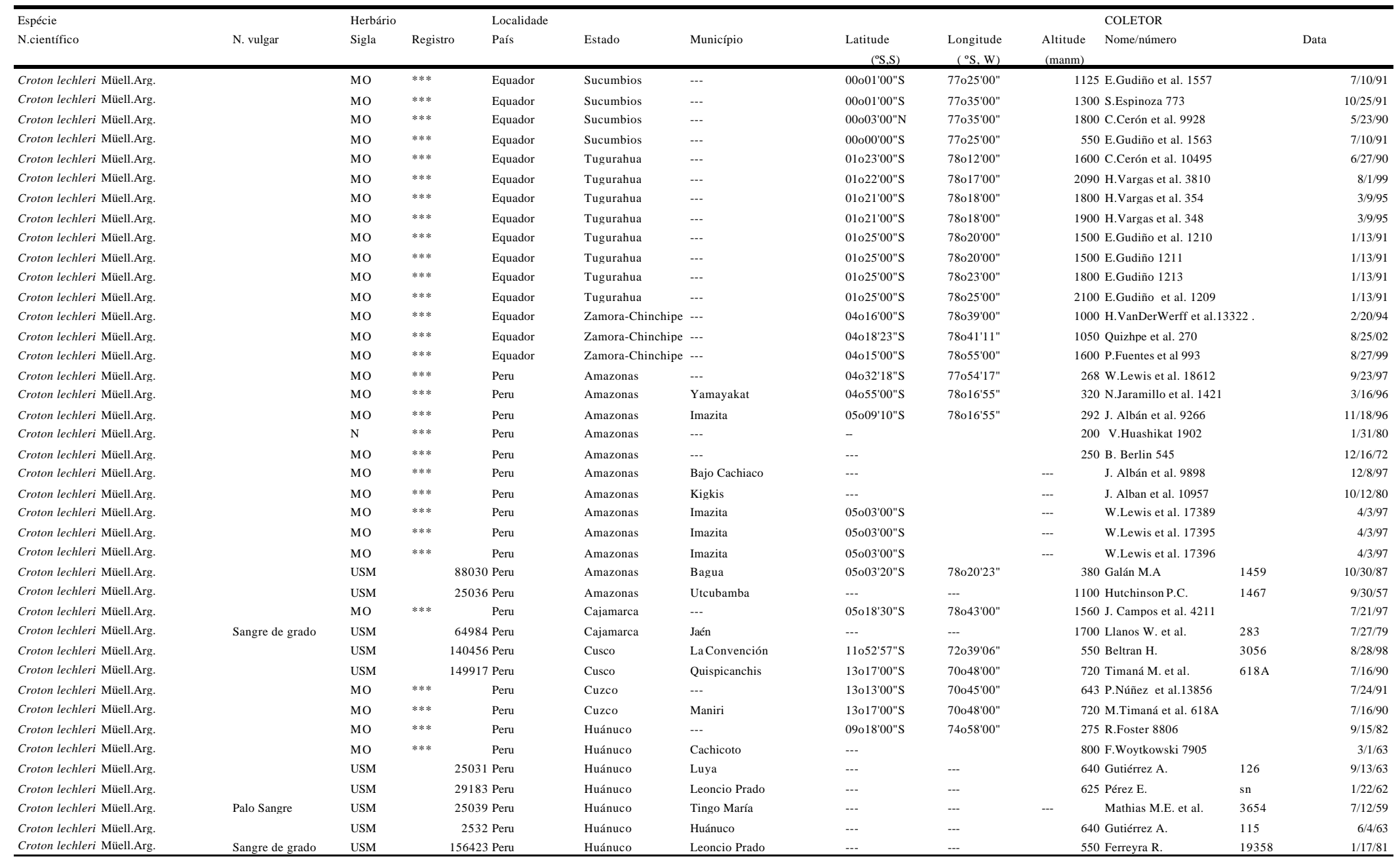




\begin{tabular}{|c|c|c|c|c|c|c|c|c|c|c|c|c|c|}
\hline \multirow{2}{*}{$\begin{array}{l}\text { Espécie } \\
\text { N.científico }\end{array}$} & \multirow[b]{2}{*}{ N. vulgar } & \multicolumn{3}{|l|}{ Herbário } & \multicolumn{2}{|l|}{ Localidade } & \multirow[b]{2}{*}{ Município } & \multirow[b]{2}{*}{ 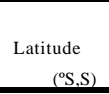 } & \multirow[b]{2}{*}{$\begin{array}{r}\text { Longitude } \\
\left({ }^{\circ} \mathrm{S}, \mathrm{W}\right) \\
\end{array}$} & \multirow[b]{2}{*}{ Altitude } & \multicolumn{2}{|l|}{ COLETOR } & \multirow[b]{2}{*}{ ta } \\
\hline & & Sigla & Registr & & País & Estado & & & & & Nome/número & & \\
\hline Crotonlechleri Müell.Arg. & & USM & & 25052 & 2 Peru & Huánuco & Huánuco & $-\ldots$ & $-\cdots$ & & 00 Smith E. & $\mathrm{sn}$ & $00 / 00 / 198$ \\
\hline Crotonlechleri Müell.Arg. & & USM & & 25106 & 5 Peru & Huánuco & Huánuco & -.- & -.- & 70 & 00 Ferreyra R. & 9307 & $6 / 21 / 5$ \\
\hline Croton lechleri Müell.Arg. & Sangre de grado & USM & & 25037 & Peru & Huánuco & Leoncio Prado & -.- & -.- & & 72 Pérez E. & sn & $00 / 09 / 196$ \\
\hline Croton lechleri Müell.Arg. & Sangre de grado & USM & & 25035 & Peru & Huánuco & Leoncio Prado & -.- & -.. & 65 & 50 Pérez E. & $\mathrm{sn}$ & 9/20/6 \\
\hline Croton lechleri Müell.Arg. & Sangre de grado & USM & & 25038 & 3 Peru & Huánuco & Leoncio Prado & -.- & -.. & 65 & 50 Pérez E. & 1 & 9/20/6 \\
\hline Crotonlechleri Müell.Arg. & & USM & & 150073 & 3 Peru & Junín & Satipo & -.. & -.- & ... & Chupurgo W.s. & $\mathrm{sn}$ & $6 / 4 / 9$ \\
\hline Crotonlechleri Müell.Arg. & & USM & & 89645 & 5 Peru & Junín & Tarma & -.- & -- & -.- & Tavar ${ }^{\circ}$ et al. & 1296 & 9/17/8 \\
\hline Crotonlechleri Müell.Arg. & Sangre de grado & USM & & 152584 & 4 Peru & Junín & Satipo & -.- & -.. & -.- & Sedano Ch. & sn & $8 / 9 / 7$ \\
\hline Crotonlechleri Müell.Arg. & & USM & & 11703 & 3 Peru & Junín & Tarma & -.- &.-- & -.- & Ridoutt C." & $\mathrm{sn}$ & $00 / 08 / 194$ \\
\hline Crotonlechleri Müell.Arg. & & USM & & 72216 & 5 Peru & Junín & Tarma & -.. & -.- & 155 & 50 Ferreyra R. & 20523 & $9 / 8 / 8$ \\
\hline Crotonlechleri Müell.Arg. & & мо & $* * * *$ & & Peru & Loreto & -- & $03015^{\circ} 00^{\prime \prime} \mathrm{s}$ & $72054^{\prime} 00^{\prime \prime}$ & 13 & 30 C.Grández 2978 & & $1 / 21 / 9$ \\
\hline Crotonlechleri Müell.Arg. & & мо & $* * * *$ & & Peru & Loreto & -- & $03015^{\circ} 00^{\prime \prime} \mathrm{s}$ & $75050^{\circ} 00^{\prime \prime}$ & 16 & 60 W.Lewis et al. 10153 & & $12 / 3 / 8$ \\
\hline Crotonlechleri Müell.Arg. & & мо & $* * *$ & & Peru & Loreto & - & $02055^{\circ} 00^{\prime \prime S}$ & $76015^{\prime} 00^{\prime \prime}$ & 26 & 60 W. Lewis et al. 10531 & & $12 / 29 / 8$ \\
\hline Crotonlechleri Müell.Arg. & & мо & *** & & Peru & Loreto & -- & $03020^{\circ} 00^{\prime \prime S}$ & $76020^{\circ} 00^{\prime \prime}$ & 18 & 85 W.Lewis et al. 11146 & & $6 / 16 / 8$ \\
\hline Crotonlechleri Müell.Arg. & & мо & **** & & Peru & Loreto & -- & $03010^{\prime} 00^{\prime \prime} \mathrm{S}$ & $76025^{\prime} 00^{\prime \prime}$ & 18 & 85 W.Lewis et al 11689 & & $7 / 5 / 8$ \\
\hline Crotonlechleri Müell.Arg. & & мо & **** & & Peru & Loreto & - & $02045^{\prime} 00^{\prime \prime S}$ & $76030^{\circ} 00^{\prime \prime}$ & 22 & 20 W.Lewis et al. 14470 & & $12 / 12 / 8$ \\
\hline Crotonlechleri Müell.Arg. & & мо & $* * *$ & & Peru & Loreto & - & $02045^{\prime} 00^{\prime \prime S}$ & $76030^{\circ} 00^{\prime \prime}$ & 22 & 20 W.Lewis et al. 14472 & & $12 / 12 / 8$ \\
\hline Croton lechleri Müell.Arg. & & мо & **** & & Peru & Loreto & -- & $02045^{\prime} 00^{\prime \prime} \mathrm{s}$ & $76030^{\circ} 00^{\prime \prime}$ & & 50 W.Lewis et al. 11059 & & $6 / 13 / 8$ \\
\hline Croton lechleri Müell.Arg. & & мо & $* * * *$ & & Peru & Loreto & -- & $02050^{\circ} 00^{\prime \prime} \mathrm{s}$ & $76055^{\prime} 00^{\prime \prime}$ & 20 & 00 W.Lewis et al.12139 & & $11 / 21 / 8$ \\
\hline Crotonlechleri Müell.Arg. & & мо & **** & & Peru & Loreto & - & $04022^{\prime} 00^{\prime \prime} \mathrm{S}$ & $77017^{\prime} 00^{\prime \prime}$ & 15 & 50 W.Lewis et al. 12990 & & $3 / 23 / 8$ \\
\hline Croton lechleri Müell.Arg. & & USM & & 136049 & Peru & Loreto & -- & $02050^{\circ} 00^{\prime \prime} \mathrm{s}$ & $76055^{\prime} 00^{\prime \prime}$ & 20 & 00 Lewis M.W. & 12136 & $11 / 21 / 8$ \\
\hline Crotonlechleri Müell.Arg. & & USM & & 151471 & Peru & Loreto & Maynas & -.- & -.- & -.. & Sobrevilla B & $\mathrm{sn}$ & $12 / 14 / 0$ \\
\hline Crotonlechleri Müell.Arg. & & USM & & 151030 & Peru & Loreto & Maynas & -.- & -.- & -.. & Sobrevilla B & $\mathrm{sn}$ & $12 / 14 / 0$ \\
\hline Croton lechleri Müell.Arg. & & USM & & 101797 & Peru & Loreto & Alto Amazonas & $03010^{\circ} 00^{\prime \prime} \mathrm{s}$ & $76025^{\prime} 00^{\prime \prime}$ & & 85 Lewis M.W. & 11689 & $7 / 5 / 8$ \\
\hline Croton lechleri Müell.Arg. & & USM & & 101510 & Peru & Loreto & Alto Amazonas & $03020^{\circ} 00^{\prime \prime} \mathrm{s}$ & $76020^{\circ} 00^{\prime \prime}$ & & 85 Lewis M.W. & 11146 & $6 / 16 / 8$ \\
\hline Crotonlechleri Müell.Arg. & Urúchnumi & USM & & 101462 & 2 Peru & Loreto & Alto Amazonas & $02045^{\circ} 00^{\prime \prime} \mathrm{S}$ & $76030^{\circ} 00^{\prime \prime}$ & 25 & 50 Lewis M.W. & 11059 & $6 / 13 / 8$ \\
\hline Crotonlechleri Müell.Arg. & & USM & & 101080 & Peru & Loreto & Loreto & $02055^{\circ} 00^{\prime \prime S}$ & $76015^{\prime} 00^{\prime \prime}$ & & 60 Lewis M.W. & 10531 & $6 / 3 / 8$ \\
\hline Croton lechleri Müell.Arg. & & USM & & 99332 & 2 Peru & Loreto & Loreto & $03015^{\prime} 00^{\prime \prime} \mathrm{s}$ & $75050^{\circ} 00^{\prime \prime}$ & 16 & 60 Lewis M.W. & 10513 & $12 / 3 / 8$ \\
\hline Croton lechleri Müell.Arg. & Sangre de grado & USM & & 63663 & 3 Peru & Loreto & Maynas & $03020^{\circ} 00^{\prime \prime} \mathrm{s}$ & $72055^{\prime} 00^{\prime \prime}$ & & 20 Macrae D. & 62 & $4 / 14 / 8$ \\
\hline Croton lechleri Müell.Arg. & & USM & & 63830 & Peru & Loreto & Maynas & $03020^{\circ} 00^{\prime \prime} \mathrm{S}$ & $72055^{\prime} 00^{\prime \prime}$ & 12 & 20 Macrae D. & 39 & $4 / 3 / 8$ \\
\hline Crotonlechleri Müell.Arg. & & USM & & 29752 & 2 Peru & Loreto & Maynas & $03020^{\circ} 00^{\prime \prime} \mathrm{S}$ & $72055^{\prime} 00^{\prime \prime}$ & 12 & 20 Gentry Al. et al. & 21741 & $5 / 12 / 7$ \\
\hline Crotonlechleri Müell.Arg. & & USM & & 2501 & Peru & Loreto & Maynas & $03020^{\circ} 00^{\prime \prime} \mathrm{s}$ & $72055^{\prime} 00^{\prime \prime}$ & 12 & 20 Plawman T. & 2579 & $3 / 3 / 6$ \\
\hline Crotonlechleri Müell.Arg. & & USM & & 25098 & 3 Peru & Loreto & Maynas & $03020^{\circ} 00^{\prime \prime} \mathrm{s}$ & $72055^{\prime} 00^{\prime \prime}$ & & 20 Plawman T. & 2569 & $2 / 25 / 6$ \\
\hline Crotonlechleri Müell.Arg. & & мо & $* * *$ & & Peru & Madre de Dios & -- & $12029^{\circ} 00^{\prime \prime} \mathrm{S}$ & $69003^{\prime} 00^{\prime \prime}$ & & 00 M.Timana 3676 & & $12 / 8 / 9$ \\
\hline Crotonlechleri Müell.Arg. & & мо & $* * *$ & & Peru & Madre de Dios & - & $12029^{\circ} 00^{\prime \prime S}$ & $69003^{\prime} 00^{\prime \prime}$ & 20 & 00 M. Timaná et al. 2179 & & $9 / 3 / 9$ \\
\hline Crotonlechleri Müell.Arg. & & мо & **** & & Peru & Madre de Dios & Iberia & $12032^{\prime} 00^{\prime \prime} \mathrm{S}$ & $69015^{\prime} 00^{\prime \prime}$ & 24 & 40 R.Vásquez et al. 12420 & & $7 / 21 / 8$ \\
\hline Croton lechleri Müell.Arg. & & мо & $* * * *$ & & Peru & Madre de Dios & -- & $12005^{\circ} 03^{\prime \prime S}$ & 6901707" & 27 & 70 P. Núñez et al. 15677 & & $8 / 27 / 9$ \\
\hline Crotonlechleri Müell.Arg. & & USM & & 97234 & 4 Peru & Madre de Dios & Tambopata & $12032^{\circ} 00^{\prime \prime} \mathrm{S}$ & $69015^{\circ} 00^{\prime \prime}$ & 24 & 40 Vásquez R. et al. & 12420 & $7 / 21 / 8$ \\
\hline
\end{tabular}




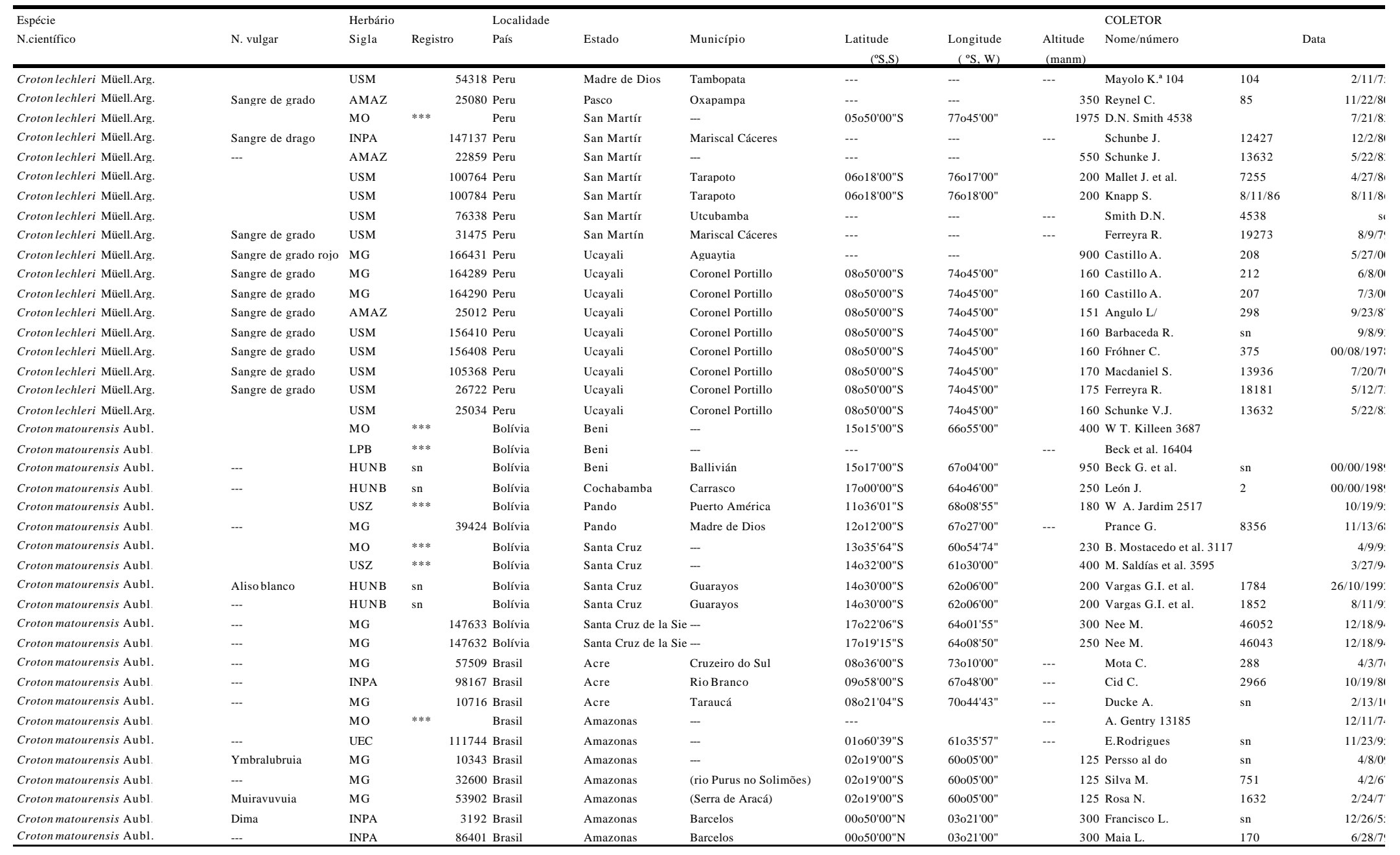




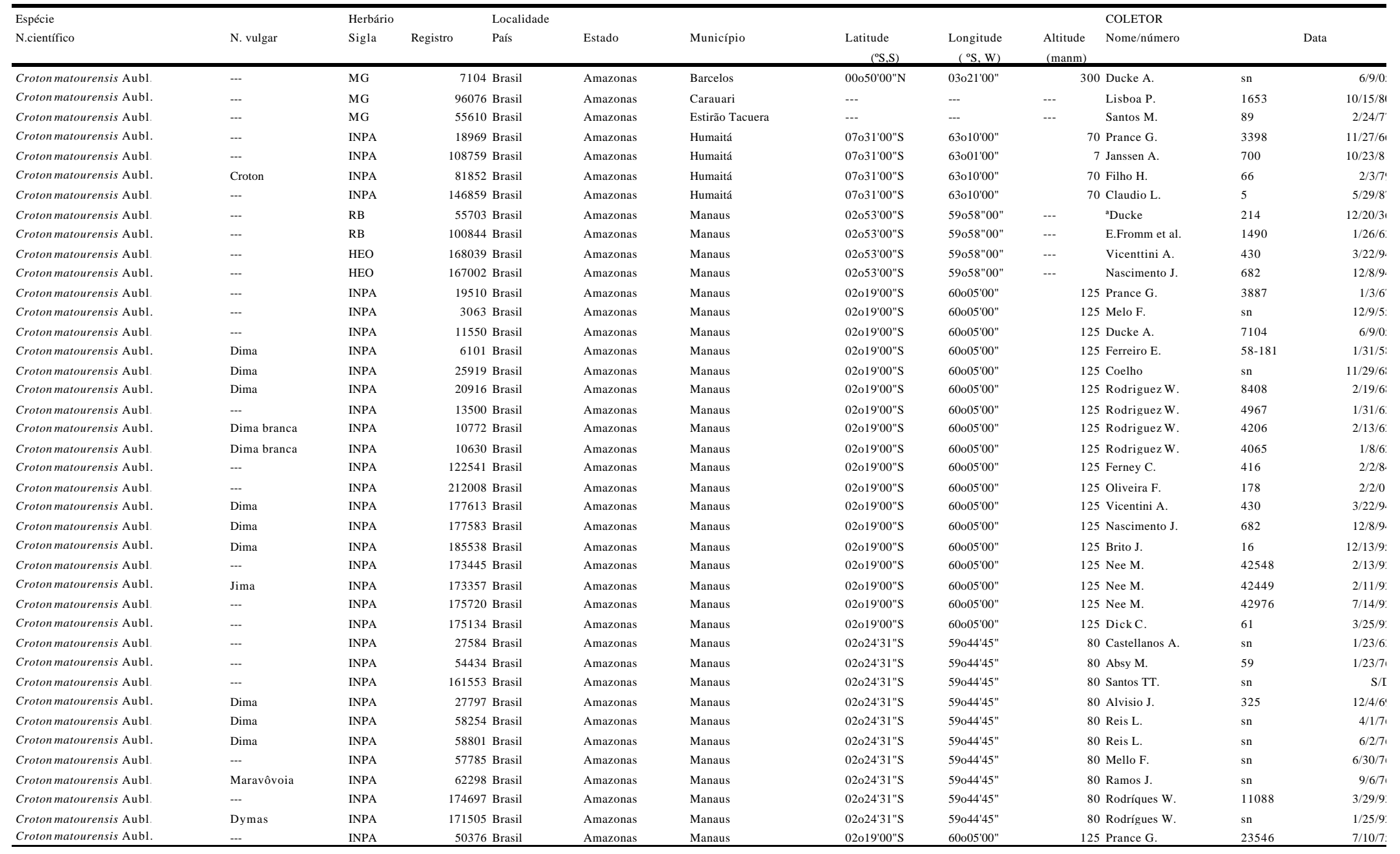




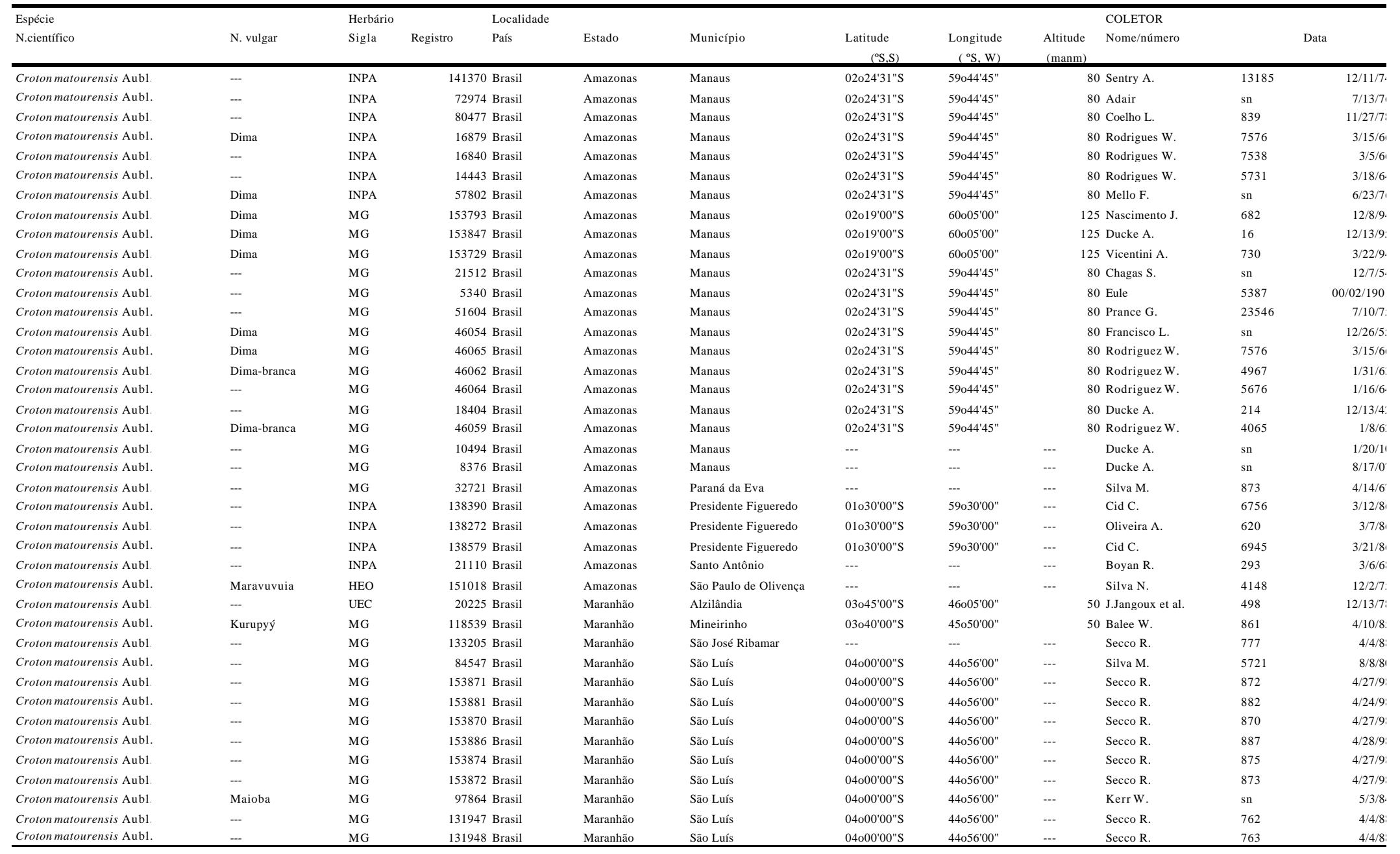




\begin{tabular}{|c|c|c|c|c|c|c|c|c|c|c|c|c|}
\hline \multirow{2}{*}{$\begin{array}{l}\text { Espécie } \\
\text { N.científico }\end{array}$} & \multirow[b]{2}{*}{ N. vulgar } & \multicolumn{2}{|c|}{ Herbário } & \multicolumn{2}{|l|}{ Localidade } & \multirow[b]{2}{*}{ Município } & \multirow[b]{2}{*}{ 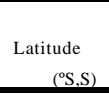 } & \multirow[b]{2}{*}{$\begin{array}{r}\text { Longitude } \\
\left({ }^{\circ} \mathrm{S}, \mathrm{W}\right) \\
\end{array}$} & \multirow[b]{2}{*}{$\begin{array}{r}\text { Altitude } \\
\text { (manm) }\end{array}$} & COLETOR & \multirow{2}{*}{\multicolumn{2}{|c|}{ Data }} \\
\hline & & Sigla & Registro & País & Estado & & & & & Nome/número & & \\
\hline Croton matourensis Aub1. & $\cdots$ & SP & 301340 & 0 Brasil & Maranhão & Turiaçu & $\cdots$ & $\ldots$ & $\cdots$ & M.R.Santos & 695 & $4 / 4 / 8$ \\
\hline Croton matourensis Aubl. & -.- & MG & 55262 & 2 Brasil & Mato Grosso & -- & $12049^{\circ} 00^{\prime \prime S}$ & $51046^{\prime} 00^{\prime \prime}$ & -.- & Cordeiro $\mathrm{M}$. & 1073 & $11 / 18 / 7$ \\
\hline Croton matourensis Aub1 & -.- & ESA & 43364 & 4 Brasil & Mato Grosso & -- & $12049^{\circ} 00^{\prime \prime} \mathrm{S}$ & $51046^{\prime} 00^{\prime \prime}$ & -- & -- & -.. & $1 / 8 / 9$ \\
\hline Croton matourensis Aubl. & -.. & ESA & 43365 & 5 Brasil & Mato Grosso & -- & $12049^{\circ} 00^{\prime \prime} \mathrm{S}$ & $51046^{\prime} 00^{\prime \prime}$ & -.- & -- & -.. & $20 / 04 / 199$ \\
\hline Croton matourensis Aubl. & -.- & MG & 3416 & 6 Brasil & Pará & -- & $02020^{\circ} 00^{\prime \prime S}$ & $55045^{\prime} 00^{\prime \prime}$ & -.- & Huber J. & $\mathrm{sn}$ & $4 / 24 / 0$ \\
\hline Croton matourensis Aubl. & Taki-taki & MG & 29126 & 6 Brasil & Pará & (Cayenne-Ouaqui) & $02020^{\circ} 00^{\prime \prime S}$ & $55045^{\prime} 00^{\prime \prime}$ & ... & Ifat & 7819 & $00 / 09 / 196$ \\
\hline Croton matourensis Aubl. & Ingui-oudou & MG & 29210 & 0 Brasil & Pará & (Cayenne-Tampoc) & $02020^{\circ} 00^{\prime \prime} \mathrm{S}$ & $55045^{\circ} 00^{\prime \prime}$ & -.- & Ifat & 7903 & $00 / 09 / 196$ \\
\hline Croton matourensis Aubl. & -.- & MG & 150835 & 5 Brasil & Pará & (Igarapé-Açu & $02020^{\circ} 00^{\prime \prime} \mathrm{s}$ & $55045^{\prime} 00^{\prime \prime}$ & ... & Oliveira F. & 64 & 2/29/9 \\
\hline Croton matourensis Aubl. & --- & INPA & 13845 & 5 Brasil & Pará & (Campos Bem-Tivi) & $02020^{\circ} 00^{\prime \prime} \mathrm{S}$ & $55045^{\prime} 00^{\prime \prime}$ & -.- & Rodrigues $\mathrm{W}$. & 5179 & $4 / 11 / 6$ \\
\hline Croton matourensis Aubl & -.- & MG & 132012 & 2 Brasil & Pará & (Salva Terra) & $02020^{\circ} 00^{\prime \prime S}$ & $55045^{\prime} 00^{\prime \prime}$ & ... & Dasilva A. & 2077 & $10 / 21 / 8$ \\
\hline Croton matourensis Aubl. & Maravuvuia & MG & 134498 & 8 Brasil & Pará & Almeirim & $00055^{\circ} 00^{\prime \prime} \mathrm{s}$ & $52044^{\prime} 00^{\prime \prime}$ & -.- & Silva N. & 5464 & $1 / 19 / 8$ \\
\hline Croton matourensis Aubl. & --- & MG & 24391 & 1 Brasil & Pará & Altos Tapajós & $07035^{\circ} 00^{\prime \prime} \mathrm{s}$ & $57031^{\prime} 00^{\prime \prime}$ & -.- & Egler W. & 1344 & $2 / 15 / 6$ \\
\hline Croton matourensis Aubl. & -.- & HEO & 159542 & 2 Brasil & Pará & Barcarena & $01025^{\prime} 00^{\prime \prime S}$ & $48027^{\prime} 00^{\prime \prime}$ & -.- & Cordeiro $\mathrm{M}$. & 1841 & $9 / 21 / 8$ \\
\hline Croton matourensis Aub1. & -.- & HEO & 125728 & 8 Brasil & Pará & Belém & -.- & -.- & -.- & Pires J. & 11712 & $3 / 29 / 6$ \\
\hline Croton matourensis Aubl. & -.- & HEO & 168399 & 9 Brasil & Pará & Belém & -.- & -.- & -.- & Gomes M. & $\mathrm{s} / \mathrm{n}$ & $\mathrm{S} / 1$ \\
\hline Croton matourensis Aubl. & -.. & HEO & 153151 & 1 Brasil & Pará & Belém & -.- & -.- & -.- & Dos Santos R. & 153151 & $7 / 30 / 7$ \\
\hline Croton matourensis Aubl. & Coroatá & HEO & 12946 & 6 Brasil & Pará & Belém & -.- & -.- & -.- & Silva A. & 84 & $2 / 4 / 4$ \\
\hline Croton matourensis Aub1. & -.- & HEO & 29115 & 5 Brasil & Pará & Belém & -.- & -.- & -.- & Rubem L. & 2 & $7 / 3 / 4$ \\
\hline Croton matourensis Aubl. & -.- & HEO & 63387 & 7 Brasil & Pará & Belém & -.- & -.. & -.- & Pires J. & 3145 & $2 / 26 / 5$ \\
\hline Croton matourensis Aubl. & -.. & HEO & 17603 & 3 Brasil & Pará & Belém & -.- & -.- & -.- & Pires J. & 620 & $11 / 13 / 4$ \\
\hline Croton matourensis Aubl. & -.- & HEO & 169371 & 1 Brasil & Pará & Belém & -.- & -.- & -.- & Cordeiro $\mathrm{M}$. & 4509 & 9/29/9 \\
\hline Croton matourensis Aubl. & -.. & MG & 54018 & 8 Brasil & Pará & Belém & -.- & -.- & -.- & Rosa N. & 1748 & $6 / 7 / 7$ \\
\hline Croton matourensis Aubl. & -.- & HEO & 177088 & 8 Brasil & Pará & Bragança & $0100700 " \mathrm{~s}$ & $46042^{\prime} 00^{\prime \prime}$ & & 30 Rios M. & 609 & $10 / 4 / 9$ \\
\hline Croton matourensis Aub1. & Marabubuaia & HEO & 177189 & 9 Brasil & Pará & Bragança & $01011^{\prime} 00 " \mathrm{~s}$ & $46040^{\circ} 00^{\prime \prime}$ & & 30 Rios M. & 759 & $5 / 2 / 0$ \\
\hline Croton matourensis Aubl. & -.- & HEO & 177135 & 5 Brasil & Pará & Bragança & $01012^{\prime} 00^{\prime \prime} \mathrm{s}$ & $46043^{\prime \prime} 00^{\prime \prime}$ & & 30 Rios M. & 705 & $2 / 21 / 0$ \\
\hline Croton matourensis Aub1. & --- & HEO & 177126 & 6 Brasil & Pará & Bragança & $01011^{\prime} 00 " \mathrm{~S}$ & $46043^{\prime} 00^{\prime \prime}$ & & 30 Rios M. & 696 & $11 / 11 / 9$ \\
\hline Croton matourensis Aubl. & -.- & HEO & 177217 & 7 Brasil & Pará & Bragança & $01011^{\prime} 00 " \mathrm{~s}$ & $46042^{\prime} 00^{\prime \prime}$ & & 30 Rios M. & 788 & $5 / 15 / 0$ \\
\hline Croton matourensis Aub1. & -.. & HEO & 177063 & 3 Brasil & Pará & Bragança & $0100700 " \mathrm{~s}$ & $46050^{\circ} 00^{\prime \prime}$ & & 30 Rios M. & 634 & $10 / 5 / 9$ \\
\hline Croton matourensis Aubl. & -.- & INPA & 131652 & 2 Brasil & Pará & Bragança & $00059^{\circ} 00^{\prime \prime} \mathrm{s}$ & $46015^{\prime} 00^{\prime \prime}$ & & 20 Davidse G. & 18018 & $4 / 8 / 8$ \\
\hline Croton matourensis Aub1. & --- & MG & 46755 & 5 Brasil & Pará & Bragança & -- & -- & -.- & E.Oliveira & 6285 & $3 / 2 / 7$ \\
\hline Croton matourensis Aubl. & -.- & MG & 46747 & 7 Brasil & Pará & Bragança & -.- & -.- & -.- & Oliveira $\mathrm{E}$. & 6275 & 3/2/7 \\
\hline Croton matourensis Aub1 & Maravuvuia & MG & 51157 & 7 Brasil & Pará & Bragança & -.- & -.- & -.- & Oliveira $\mathrm{E}$. & 6411 & 2/27/7 \\
\hline Croton matourensis Aubl. & -.- & $\mathrm{RB}$ & 20031 & 1 Brasil & Pará & Campos Gerais & -.. & -.. & -.- & "Sampaio & 5821 & $12 / 7 / 2$ \\
\hline Croton matourensis Aub1. & --- & MG & 46253 & 3 Brasil & Pará & Capitão Poço & -.- & --- & $-\cdots$ & Oliveira $\mathrm{E}$. & 6166 & $4 / 3 / 7$ \\
\hline Croton matourensis Aub1 & -.- & MG & 46739 & 9 Brasil & Pará & Capitão Poço & -.- & -.- & -.- & Oliveira $\mathrm{E}$. & 6265 & $2 / 25 / 7$ \\
\hline Croton matourensis Aub1 & -.- & HEO & 164081 & 1 Brasil & Pará & Curaçã & -.- & -.- & -.. & Bayma J. & 1 & $12 / 22 / 9$ \\
\hline Croton matourensis Aubl. & -.- & MG & 53130 & 0 Brasil & Pará & Inhangapi & -.. & -.. & -.. & Oliveira $\mathrm{E}$. & 6557 & 2/8/7 \\
\hline Croton matourensis Aubl. & $\ldots$ & $\mathrm{SP}$ & 344407 & 7 Brasil & Pará & Ipixuna do Pará & $\ldots$ & $\ldots$ & $\ldots$ & C.Yamashita & $\mathrm{sn}$ & $5 / 4 / 0$ \\
\hline
\end{tabular}




\begin{tabular}{|c|c|c|c|c|c|c|c|c|c|c|c|c|c|}
\hline \multirow{2}{*}{$\begin{array}{l}\text { Espécie } \\
\text { N.científico }\end{array}$} & \multirow[b]{2}{*}{ N. vulgar } & \multicolumn{3}{|c|}{ Herbário } & \multicolumn{2}{|l|}{ Localidade } & \multirow[b]{2}{*}{ Município } & \multirow[b]{2}{*}{ 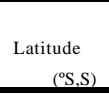 } & \multirow[b]{2}{*}{$\begin{array}{r}\text { Longitude } \\
\left({ }^{\circ} \mathrm{S}, \mathrm{W}\right) \\
\end{array}$} & \multirow[b]{2}{*}{$\begin{array}{r}\text { Altitude } \\
(\mathrm{manm})\end{array}$} & COLETOR & \multirow{2}{*}{\multicolumn{2}{|c|}{ Data }} \\
\hline & & Sigla & Registr & & País & Estado & & & & & e Nome/número & & \\
\hline Croton matourensis Aub1. & $\cdots$ & MG & & 46732 & 2 Brasil & Pará & Maracanã & -- & $\ldots$ & $\cdots$ & Oliveira $\mathrm{E}$. & 6258 & $2 / 22 / 7:$ \\
\hline Croton matourensis Aubl. & -.- & HEO & & 116268 & 3 Brasil & Pará & Marapanim & -.- & -.- & -.- & Oliveira E. & 3308 & 3/20/6 \\
\hline Croton matourensis Aub1 & -.- & MG & & 24527 & Brasil & Pará & Marapanim & -- & -.- & -- & Egler W. & 1371 & $3 / 19 / 61$ \\
\hline Croton matourensis Aubl. & -.. & MG & & 24526 & 5 Brasil & Pará & Marapanim & -.- & -.. & -.- & Egler $\mathrm{W}$. & 1370 & $3 / 19 / 61$ \\
\hline Croton matourensis Aubl. & Arikena & MG & & 31761 & Brasil & Pará & Marapanim & -.- & -.. & -.- & Elias J. & 237 & $5 / 25 / 61$ \\
\hline Croton matourensis Aubl. & -.- & MG & & 95589 & Brasil & Pará & Marapanim & $00056^{\circ} 00^{\prime \prime} \mathrm{s}$ & $47039^{\circ} 00^{\prime \prime}$ & & 50 Davidse G. & 17907 & $4 / 5 / 81$ \\
\hline Croton matourensis Aubl. & -.- & MG & & 31762 & 2 Brasil & Pará & Marapanim & $\cdots$ & -- & -.- & Elias J. & 233 & $5 / 12 / 6$ \\
\hline Croton matourensis Aubl. & -.. & MG & & 74438 & Brasil & Pará & Taboca & $10015^{\prime} 00^{\prime \prime} \mathrm{s}$ & $63020^{\circ} 00^{\prime \prime}$ & -.- & Vieira G. & 358 & 10/10/7! \\
\hline Croton matourensis Aubl. & --- & INPA & & 117684 & 4 Brasil & Pará & Oriximiná & $01003^{\prime} 00^{\prime S} \mathrm{~S}$ & $57003^{\prime} 00^{\prime \prime}$ & & 80 Davidson C. & 10643 & $31 / 06 / 1981$ \\
\hline Croton matourensis Aubl & Dimá & INPA & & 123951 & Brasil & Pará & Oriximiná & $01003^{\prime} 00^{\prime \prime S}$ & $57003^{\prime} 00^{\prime \prime}$ & & 80 Knowler $\mathrm{O}$. & $\mathrm{sn}$ & 4/10/8: \\
\hline Croton matourensis Aubl. & -.- & INPA & & 198180 & Brasil & Pará & Oriximiná & $01003^{\prime} 00^{\prime \prime S}$ & $57003^{3} 00^{\prime \prime}$ & & 80 Barbosa E. & 43 & 00/00/199! \\
\hline Croton matourensis Aubl. & -.. & INPA & & 198195 & Brasil & Pará & Oriximiná & $01003^{\prime} 00^{\prime \prime} \mathrm{s}$ & $57003^{\prime} 00^{\prime \prime}$ & & 80 Barbosa E. & 65 & $00 / 00 / 199^{\prime}$ \\
\hline Croton matourensis Aubl. & -.- & INPA & & 94277 & Brasil & Pará & Oriximiná & $01003^{\prime} 00^{\prime \prime S}$ & $57003^{\prime} 00^{\prime \prime}$ & & $80 \mathrm{Cid} \mathrm{C}$. & 1083 & 6/19/81 \\
\hline Croton matourensis Aub1. & -.- & INPA & & 141924 & 4 Brasil & Pará & Oriximiná & $01003^{\prime} 00^{\prime \prime S}$ & $57003^{3} 00^{\prime \prime}$ & & 80 Soares E. & 66 & $00 / 00 / 198$ \\
\hline Croton matourensis Aubl. & -.- & MG & & 61589 & Brasil & Pará & Oriximiná & $01003^{\prime} 00^{\prime \prime S}$ & $57003^{3} 00^{\prime \prime}$ & & 80 Silva $\mathrm{N}$. & 4624 & 5/24/7: \\
\hline Croton matourensis Aubl. & Casca-gaivota & MG & & 49521 & Brasil & Pará & Oriximiná & $01003^{\prime} 00^{\prime \prime S}$ & $57003^{\prime} 00^{\prime \prime}$ & & 80 Ducke A. & $\mathrm{sn}$ & $1 / 9 / 2^{2}$ \\
\hline Croton matourensis Aubl. & -.- & HEO & & 147855 & 5 Brasil & Pará & Paragominas & -.- & -.- & -.- & Santos $R$. & 25 & $3 / 27 / 7$ \\
\hline Croton matourensis Aub1. & -.- & MG & & 73891 & Brasil & Pará & Paragominas & -.- & -.- & -.- & Maciel U. & 439 & $12 / 6 / 7$ \\
\hline Croton matourensis Aubl. & Muiravuvuia & MG & & 138825 & 5 Brasil & Pará & Peixe-Boi & $01011^{\prime} 00 " \mathrm{~s}$ & $47019^{\prime} 00^{\prime \prime}$ & -.- & Salomao R. & 692 & $3 / 11 / 9$ \\
\hline Croton matourensis Aubl. & -.. & MG & & 35637 & Brasil & Pará & Quatipuru & -.- & -.- & -.- & Rodriguez W. & 5179 & $4 / 11 / 6$ \\
\hline Croton matourensis Aubl. & -.- & MG & & 62191 & Brasil & Pará & Salva Terra & -.- & -.- & -.- & Bastos $\mathrm{N}$. & 41 & 3/16/7: \\
\hline Croton matourensis Aubl. & -.. & HEO & & 160197 & Brasil & Pará & Vigia & $00057^{\circ} 00^{\prime \prime S}$ & $48005^{\prime} 00^{\prime \prime}$ & -.- & Davidse C. & 17650 & $3 / 30 / 81$ \\
\hline Croton matourensis Aubl. & -.- & MG & & 113312 & 2 Brasil & Pará & Vigia & -.- & -.- & -.- & Lobato L. & 38 & $2 / 21 / 8$ \\
\hline Croton matourensis Aub1. & -.- & MG & & 95449 & Brasil & Pará & Vigia & $00057^{\circ} 00^{\prime \prime S}$ & $47039^{\circ} 00^{\prime \prime}$ & & 50 Davidse G. & 17650 & $3 / 30 / 81$ \\
\hline Croton matourensis Aubl. & Maravuvuia & MG & & 69746 & 6 Brasil & Pará & Vigia & -.- & -.. & -.- & Silva M. & 5174 & $3 / 30 / 81$ \\
\hline Croton matourensis Aub1. & --- & INPA & & 173635 & 5 Brasil & Rondônia & (Serra da onça-Jaruvari) & -- & -- & -.- & Franca J. & 473 & $12 / 13 / 8$ \\
\hline Croton matourensis Aubl. & -.- & INPA & & 90156 & 5 Brasil & Rondônia & Ariquemes & $10034^{\prime} 00^{\prime \prime S}$ & 63037'00" & -.- & Zarucchi J. & 2686 & $10 / 14 / 7$ \\
\hline Croton matourensis Aub1. & -.. & INPA & & 88683 & 3 Brasil & Rondônia & Ariquemes & $10015^{\prime} 00^{\prime \prime S}$ & $63020^{\prime} 00^{\prime \prime}$ & -.- & Vieira G. & 358 & 10/10/7! \\
\hline Croton matourensis Aubl. & -.- & MG & & 74577 & Brasil & Rondônia & Ariquemes & $10035^{\prime} 30^{\prime \prime} \mathrm{s}$ & $63037^{\prime} 00^{\prime \prime}$ & -.- & Vieira G. & 523 & $10 / 18 / 7$ \\
\hline Croton matourensis Aub1. & --- & MG & & 87238 & 3 Brasil & Rondônia & Guajará-Mirim & -- & --- & -.- & Carreira Leo & 329 & $1 / 28 / 8$ \\
\hline Croton matourensis Aubl. & -.- & MG & & 41615 & Brasil & Rondônia & Porto Velho & $09000^{\circ} 00^{\prime \prime S}$ & $62044^{\prime} 05^{\prime \prime}$ & & 115 Prance G. & 8835 & 11/24/6 \\
\hline Croton matourensis Aub1 & -.- & MG & & 45978 & 3 Brasil & Roraima & -- & & $60020^{\circ} 00^{\prime \prime}$ & -.. & Pires J. & 14576 & $6 / 22 / 7$ \\
\hline Croton matourensis Aubl. & -.- & MG & & 35030 & Brasil & Roraima & - & $00025^{\prime} 00^{\prime \prime} \mathrm{N}$ & $60020^{\circ} 00^{\prime \prime}$ & -.- & Prince G. & 4343 & $2 / 12 / 6$ \\
\hline Croton matourensis Aub1 & --- & MG & & 41555 & Brasil & Roraima & (RIO Madeiras) & $03024^{\prime} 00^{\prime \prime} \mathrm{N}$ & $61026^{\prime} 00^{\prime \prime}$ & -.- & Prance G. & 8356 & $11 / 12 / 6$ \\
\hline Croton matourensis Aub1 & -.- & INPA & & 19978 & 3 Brasil & Roraima & (Serra Tepequem) & $03024^{\prime} 00^{\prime \prime N}$ & $61026^{\prime} 00^{\prime \prime}$ & -.- & Prance G. & 4343 & $2 / 12 / 6$ \\
\hline Croton matourensis Aub1 & -.- & MG & & 149764 & 4 Brasil & Roraima & Vila Pacaraima & -.- & -.- & -.. & Almeida $\mathrm{S}$. & 628 & $10 / 19 / 9$ \\
\hline Croton matourensis Aub1. & Ojo de sadina & $\mathrm{COL}$ & **** & & Colômbia & Amazonas & -- & -.. & & & 150 A. Roa 675 & & \\
\hline Croton matourensis Aubl. & Erarikague & INPA & & 85810 & Colômbia & Amazonas & -- & $\ldots$ & $\ldots$ & $\ldots$ & Roa A. & 675 & $5 / 25 / 77^{\prime}$ \\
\hline
\end{tabular}




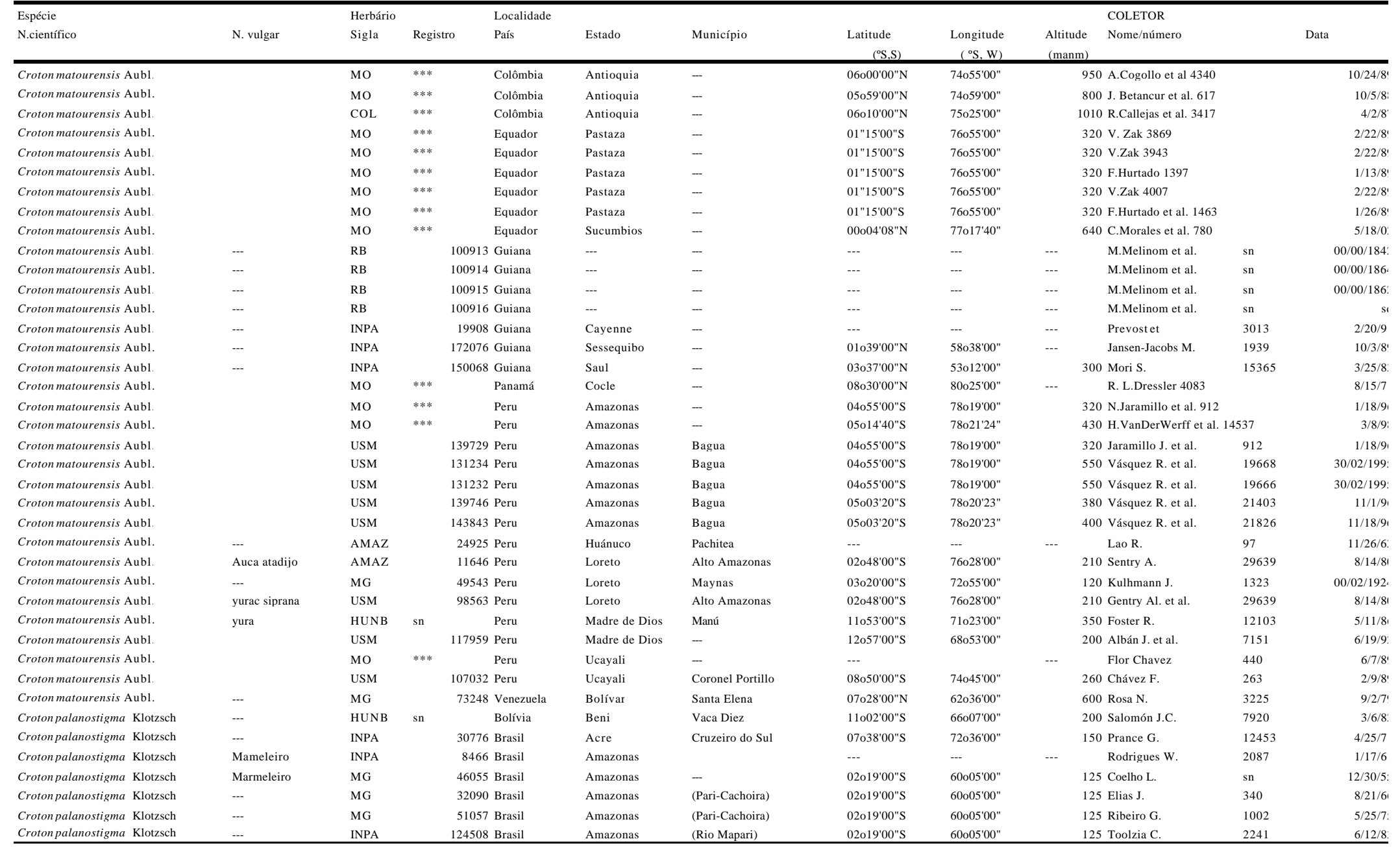




\begin{tabular}{|c|c|c|c|c|c|c|c|c|c|c|c|c|}
\hline \multirow{2}{*}{$\begin{array}{l}\text { Espécie } \\
\text { N.científico }\end{array}$} & \multirow[b]{2}{*}{ N. vulgar } & \multicolumn{2}{|c|}{ Herbário } & \multicolumn{2}{|l|}{ Localidade } & \multirow[b]{2}{*}{ Município } & \multirow[b]{2}{*}{ 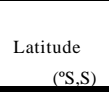 } & \multirow[b]{2}{*}{$\begin{array}{r}\text { Longitude } \\
\left({ }^{\circ} \mathrm{S}, \mathrm{W}\right) \\
\end{array}$} & \multicolumn{2}{|r|}{ COLETOR } & \multirow{2}{*}{\multicolumn{2}{|c|}{ Data }} \\
\hline & & Sigla & Registro & País & Estado & & & & $\begin{array}{l}\text { Altitude } \\
\text { (manm) }\end{array}$ & Nome/número & & \\
\hline Croton palanostigma Klotzsch & $\cdots$ & INPA & 144391 & 1 Brasil & Amazonas & Barcelos & $00050^{\prime} 00^{\prime \prime} \mathrm{N}$ & $03021^{\prime} 00^{\prime \prime}$ & & 00 Cordeiro I. & 225 & $7 / 20 / 8$ \\
\hline Croton palanostigma Klotzsch & -.. & SP & 252877 & 7 Brasil & Amazonas & Barcelos & $00042^{\prime} 00^{\prime \prime N}$ & 63022'00" & -.- & I.Cordeiro et al. & 192 & $7 / 9 / 8$ \\
\hline Croton palanostigma Klotzsch & -.- & SP & 252886 & 6 Brasil & Amazonas & Barcelos & $00050^{\circ} 00^{\prime \prime} \mathrm{N}$ & $63021^{\prime} 00^{\prime \prime}$ & & 00 I.Cordeiro et al. & 225 & $7 / 20 / 8$ \\
\hline Croton palanostigma Klotzsch & Marmeleiro & MG & 34046 & 6 Brasil & Amazonas & Huamaitá & $07031^{\prime} 00^{\prime \prime S}$ & $63010^{\prime} 00^{\prime \prime}$ & & 1 Prince G. & 3409 & $11 / 27 / 6$ \\
\hline Croton palanostigma Klotzsch & -.- & MG & 85306 & 6 Brasil & Amazonas & Huamaitá & $070311^{\prime} 00 " \mathrm{~S}$ & $63010^{\circ} 00^{\prime \prime}$ & & 1 Jansen A. & 245 & $3 / 3 / 8$ \\
\hline Croton palanostigma Klotzsch & -..- & MG & 85276 & 6 Brasil & Amazonas & Huamaitá & $070311^{\circ} 00^{\prime S}$ & $63010^{\prime} 00^{\prime \prime}$ & & 1 Janssen A. & 93 & $12 / 26 / 7$ \\
\hline Croton palanostigma Klotzsch & -.- & HEO & 149642 & 2 Brasil & Amazonas & Iaureté & -.- & 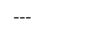 & -.- & Ribeiro B. & 952 & $5 / 16 / 7$ \\
\hline Croton palanostigma Klotzsch & -.. & INPA & 90774 & 4 Brasil & Amazonas & Lago Carauacá-Rio Iça & ... & -.. & $\ldots$ & Prance G. & 24529 & $2 / 23 / 7$ \\
\hline Croton palanostigma Klotzsch & --- & $\mathrm{RB}$ & 55702 & 2 Brasil & Amazonas & Manaus & 02024'31"S & $59044^{4} 45^{\prime \prime}$ & & 80 a Ducke & 383 & $1 / 6 / 3$ \\
\hline Croton palanostigma Klotzsch & -.. & $\mathrm{RB}$ & 118568 & 8 Brasil & Amazonas & Manaus & $0202431 " \mathrm{SS}$ & $59044^{4} 45^{\prime \prime}$ & & 80 G.T.Prance et al. & 3857 & $1 / 2 / 6$ \\
\hline Croton palanostigma Klotzsch & -.- & MG & 46060 & 0 Brasil & Amazonas & Manaus & $02024^{\prime 3} 1 \mathrm{lS}$ & $59044^{4} 45^{\prime \prime}$ & & 80 Rodriguez W. & 4181 & $2 / 1 / 6$ \\
\hline Croton palanostigma Klotzsch & Marmeleiro & MG & 46063 & 3 Brasil & Amazonas & Manaus & $0202431 " \mathrm{~S}$ & $59044^{4} 45^{\prime \prime}$ & & 80 Rodriguez W. & 5024 & $4 / 8 / 6$ \\
\hline Croton palanostigma Klotzsch & -.- & MG & 18406 & 6 Brasil & Amazonas & Manaus & $0202431 " \mathrm{~S}$ & $59044^{4} 45^{\prime \prime}$ & & 80 Ducke A. & 383 & $12 / 16 / 4$ \\
\hline Croton palanostigma Klotzsch & -.- & MG & 42502 & 2 Brasil & Amazonas & Manaus & $0202431 " \mathrm{~s}$ & $59044^{4} 45^{\prime \prime}$ & & 80 Prince G. & 11486 & $1 / 27 / 7$ \\
\hline Croton palanostigma Klotzsch & -.- & MG & 34310 & 0 Brasil & Amazonas & Manaus & $0202431 " \mathrm{~s}$ & $59044^{4} 45^{\prime \prime}$ & & 80 Prince G. & 3857 & $1 / 2 / 6$ \\
\hline Croton palanostigma Klotzsch & Marmeleiro & MG & 21894 & 4 Brasil & Amazonas & Manaus & 02024'31"S & $59044^{4} 45^{\prime \prime}$ & & 80 Dionisio $\mathrm{S}$. & $\mathrm{sn}$ & $12 / 19 / 5$ \\
\hline Croton palanostigma Klotzsch & -.- & MG & 153763 & 3 Brasil & Amazonas & Manaus & $02019^{\circ} 00^{\prime \prime} \mathrm{s}$ & $60005^{\prime} 00^{\prime \prime}$ & & 25 Vicentini A. & 1164 & $12 / 12 / 9$ \\
\hline Croton palanostigma Klotzsch & -.- & MG & 21517 & 7 Brasil & Amazonas & Manaus & $02019^{\prime} 00^{\prime \prime} \mathrm{s}$ & $60005^{\prime} 00^{\prime \prime}$ & & 25 Chagas J. & $\mathrm{sn}$ & $8 / 22 / 5$ \\
\hline Croton palanostigma Klotzsch & Marmeleiro & MG & 46057 & 7 Brasil & Amazonas & Manaus & $02019^{\circ} 00^{\prime \prime} \mathrm{s}$ & $60005^{5} 00^{\prime \prime}$ & & 25 Rodriguez W. & 1548 & $3 / 31 / 6$ \\
\hline Crotonpalanostigma Klotzsch & -.. & MG & 46058 & 8 Brasil & Amazonas & Manaus & $02019^{\circ} 00^{\prime \prime} \mathrm{s}$ & $60005^{\prime} 00^{\prime \prime}$ & & 25 Rodriguez W. & 3844 & $12 / 7 / 6$ \\
\hline Croton palanostigma Klotzsch & -.- & HEO & 18005 & 5 Brasil & Amazonas & Manaus & $02019^{\prime} 00^{\prime \prime} \mathrm{s}$ & $60005^{\prime} 00^{\prime \prime}$ & & 25 Pires J. & 1022 & $12 / 20 / 4$ \\
\hline Crotonpalanostigma Klotzsch & Marmeleiro & HEO & 92256 & 6 Brasil & Amazonas & Manaus & $02019^{\circ} 00^{\prime \prime} \mathrm{s}$ & $60005^{\prime} 00^{\prime \prime}$ & & 25 Francisco $\mathrm{L}$. & $\mathrm{s} / \mathrm{n}$ & $12 / 30 / 5$ \\
\hline Croton palanostigma Klotzsch & -.- & HEO & 166937 & 7 Brasil & Amazonas & Manaus & $02019^{\circ} 00^{\prime \prime} \mathrm{s}$ & $60005^{5} 00^{\prime \prime}$ & & 25 Vicentini A. & 735 & $10 / 12 / 9$ \\
\hline Croton palanostigma Klotzsch & -.- & HEO & 9964 & 4 Brasil & Amazonas & Manaus & $02019^{\prime} 00^{\prime \prime} \mathrm{s}$ & $60005^{\prime} 00^{\prime \prime}$ & & 25 Ducke A. & 383 & $12 / 16 / 4$ \\
\hline Croton palanostigma Klotzsch & -.- & INPA & 13685 & 5 Brasil & Amazonas & Manaus & $02019^{\circ} 00^{\prime \prime} \mathrm{s}$ & $60005^{\prime} 00^{\prime \prime}$ & & 25 Rodrigues $\mathrm{W}$. & 5024 & $4 / 8 / 6$ \\
\hline Croton palanostigma Klotzsch & Mameleiro & INPA & 10747 & 7 Brasil & Amazonas & Manaus & $02019^{\prime} 00^{\prime \prime S}$ & $60005^{\prime} 00^{\prime \prime}$ & 12 & 25 Rodrigues $\mathrm{W}$. & 4181 & $2 / 1 / 6$ \\
\hline Croton palanostigma Klotzsch & Mameleiro & INPA & 10408 & 8 Brasil & Amazonas & Manaus & $02019^{\circ} 00^{\prime \prime} \mathrm{s}$ & $60005^{5} 00^{\prime \prime}$ & & 25 Rodrigues $\mathrm{W}$. & 3844 & $12 / 7 / 6$ \\
\hline Croton palanostigma Klotzsch & Mameleiro & INPA & 7911 & 1 Brasil & Amazonas & Manaus & $02019^{\circ} 00^{\prime \prime S}$ & $60005^{5} 00^{\prime \prime}$ & 12 & 25 Chagas $R$. & 1548 & $3 / 31 / 6$ \\
\hline Croton palanostigma Klotzsch & Mameleiro & INPA & 3224 & 4 Brasil & Amazonas & Manaus & $02019^{\circ} 00^{\prime \prime} \mathrm{s}$ & $60005^{\prime} 00^{\prime \prime}$ & 12 & 25 Francisco $\mathrm{L}$. & $\mathrm{sn}$ & $12 / 30 / 5$ \\
\hline Croton palanostigma Klotzsch & --- & INPA & 177622 & 2 Brasil & Amazonas & Manaus & $02019^{\prime} 00^{\prime \prime S}$ & $60005^{\prime} 00^{\prime \prime}$ & & 25 Vicentini A. & 735 & $10 / 12 / 9$ \\
\hline Croton palanostigma Klotzsch & -.- & INPA & 185558 & 8 Brasil & Amazonas & Manaus & $02019^{\circ} 00^{\prime \prime} \mathrm{s}$ & $60005^{5} 00^{\prime \prime}$ & 12 & 25 Vicenttini A. & 1164 & $12 / 12 / 9$ \\
\hline Croton palanostigma Klotzsch & -.- & INPA & 92683 & 3 Brasil & Amazonas & Manaus & $02019^{\prime} 00^{\prime \prime} \mathrm{s}$ & $60005^{\prime} 00^{\prime \prime}$ & & 25 Coêlho L. & 1766 & $6 / 26 / 8$ \\
\hline Croton palanostigma Klotzsch & -.- & INPA & 92457 & 7 Brasil & Amazonas & Manaus & $02019^{\circ} 00^{\prime \prime} \mathrm{s}$ & $60005^{\prime} 00^{\prime \prime}$ & & 25 Coêlho D. & $\mathrm{sn}$ & $12 / 11 / 7$ \\
\hline Croton palanostigma Klotzsch & Mameleiro & INPA & 3141 & 1 Brasil & Amazonas & Manaus & $02019^{\prime} 00^{\prime \prime S}$ & $60005^{\prime} 00^{\prime \prime}$ & & 25 Coêlho D. & $\mathrm{sn}$ & $12 / 19 / 5$ \\
\hline Croton palanostigma Klotzsch & Mameleiro & INPA & 1694 & 4 Brasil & Amazonas & Manaus & $02019^{\circ} 00^{\prime \prime} \mathrm{s}$ & $60005^{5} 00^{\prime \prime}$ & 12 & 25 Rodrigues $\mathrm{W}$. & $\mathrm{sn}$ & $8 / 22 / 5$ \\
\hline Croton palanostigma Klotzsch & -.- & INPA & 175173 & 3 Brasil & Amazonas & Manaus & $02022^{\prime} 00^{\prime \prime} \mathrm{s}$ & $59057^{\prime} 00^{\prime \prime}$ & & 20 Dick C. & 104 & $4 / 11 / 9$ \\
\hline Crotonpalanostigma Klotzsch & -.- & HEO & 149692 & 2 Brasil & Amazonas & Pari-Cachoeira & -.. & -.. & -.. & Ribeiro B. & 1.002 & $5 / 25 / 7$ \\
\hline Croton palanostigma Klotzsch & $\ldots$ & INPA & 198576 & 6 Brasil & Amazonas & Presidente Figueredo & $01030^{\circ} 00^{\prime \prime} \mathrm{s}$ & $59030^{\circ} 00^{\prime \prime}$ & $\ldots$ & Silva J. & 873 & $2 / 9 / 9$ \\
\hline
\end{tabular}




\begin{tabular}{|c|c|c|c|c|c|c|c|c|c|c|c|c|}
\hline \multirow{2}{*}{$\begin{array}{l}\text { Espécie } \\
\text { N.científico }\end{array}$} & \multirow[b]{2}{*}{ N. vulgar } & \multicolumn{2}{|c|}{ Herbário } & \multicolumn{2}{|l|}{ Localidade } & \multirow[b]{2}{*}{ Município } & \multirow[b]{2}{*}{$\begin{array}{l}\text { Latitude } \\
\left({ }^{\circ}, \mathrm{S}, \mathrm{S}\right)\end{array}$} & \multirow[b]{2}{*}{$\begin{array}{r}\text { Longitude } \\
\left({ }^{\circ} \mathrm{S}, \mathrm{W}\right)\end{array}$} & \multirow[b]{2}{*}{$\begin{array}{r}\text { Altitude } \\
\text { (manm) }\end{array}$} & \multirow{2}{*}{$\begin{array}{l}\text { COLETOR } \\
\text { Nome/número }\end{array}$} & \multirow{2}{*}{\multicolumn{2}{|c|}{ Data }} \\
\hline & & Sigla & Registro & País & Estado & & & & & & & \\
\hline Croton palanostigma Klotzsch & --- & INPA & 195912 & 2 Brasil & Amazonas & Presidente Figueredo & $01030^{\circ} 00^{\prime \prime} \mathrm{s}$ & $59030^{\circ} 00^{\prime \prime}$ & --- & Vieira $M$. & 1302 & $10 / 8 / 9^{\circ}$ \\
\hline Crotonpalanostigma Klotzsch & --- & MG & 140307 & 7 Brasil & Amazonas & São Grab. da Cachoeira & $00018^{\prime} 00^{\prime \prime} \mathrm{N}$ & $66042^{2} 00^{\prime \prime}$ & & 350 Daly D. & 5418 & $10 / 15 / 8^{\prime}$ \\
\hline Croton palanostigma Klotzsch & --- & HEO & 146719 & 9 Brasil & Amazonas & São Grab. da Cachoeira & $00018^{\prime} 00^{\prime \prime} \mathrm{N}$ & $67039^{\circ} 00^{\prime \prime}$ & $\cdots$ & Pires J. & 15806 & 3/13/7: \\
\hline Croton palanostigma Klotzsch & Croton & INPA & 18127 & 7 Brasil & Amazonas & São Grab. da Cachoeira & $00018^{\prime} 00^{\prime \prime} \mathrm{N}$ & $67039^{\circ} 00^{\prime \prime}$ & -.- & Krob A. & 1103 & $10 / 10 / 9$ \\
\hline Croton palanostigma Klotzsch & -.- & MG & 23375 & 5 Brasil & Amazonas & Taracuá & $03002^{\prime} \cdot 00^{\prime \prime} \mathrm{s}$ & $600088^{\prime} 00^{\prime \prime}$ & -.. & Cavalcantte $P$. & 728 & 3/3/5 \\
\hline Crotonpalanostigma Klotzsch & --- & INPA & 19481 & 1 Brasil & Amazonas & Tarumã & $03002^{2} 00^{\prime \prime S}$ & $60008^{\prime} 00^{\prime \prime}$ & --- & Prance G. & 3857 & $1 / 2 / 6$ \\
\hline Croton palanostigma Klotzsch & --- & MG & 116549 & 9 Brasil & Amazonas & Tefé & $03020^{\circ} 00^{\prime \prime} \mathrm{s}$ & $64050^{\circ} 00^{\prime \prime}$ & -.. & Plawman J. & 12514 & 12/13/8: \\
\hline Croton palanostigma Klotzsch & --- & MG & 116517 & 7 Brasil & Amazonas & Tefé & $03020^{\circ} 00^{\prime \prime} \mathrm{S}$ & $64050^{\circ} 00^{\prime \prime}$ & $\cdots$ & Plawman $\mathrm{T}$. & 12475 & 12/13/8: \\
\hline Croton palanostigma Klotzsch & Murucututu & HEO & 29647 & 7 Brasil & Amazonas & Tefé & $0302000 " \mathrm{~s}$ & $64050^{\circ} 00^{\prime \prime}$ & -.. & Black G. & $47-1186$ & $8 / 15 / 4$ \\
\hline Croton palanostigma Klotzsch & -.- & MG & 49535 & 5 Brasil & Amazonas & Tonantins & -.. & -- & -.. & Kuhlmann J. & 1245 & $1 / 24 / 41$ \\
\hline Croton palanostigma Klotzsch & Balsa-rana & HEO & 11057 & 7 Brasil & Amazonas & Tonantins & -.. & -- & -.- & ducke A. & 1564 & 2/24/4. \\
\hline Croton palanostigma Klotzsch & --- & HEO & 33569 & 9 Brasil & Amazonas & Tunuí & -.. & -- & -.- & Black G. & $48-2872$ & 5/10/4: \\
\hline Croton palanostigma Klotzsch & -.- & HEO & 28232 & 2 Brasil & Amazonas & Tupuruquara & -.. & -- & -.. & Pires J. & 276 & $4 / 7 / 4^{\prime}$ \\
\hline Crotonpalanostigma Klotzsch & -.- & MG & 111344 & 4 Brasil & Maranhão & Lago Verde & $04026^{\prime} 00^{\prime \prime} \mathrm{S}$ & $44058^{\prime} 00^{\prime \prime}$ & -.- & Anderson A. & 2014 & 3/20/8: \\
\hline Croton palanostigma Klotzsch &.-- & MG & 111406 & 6 Brasil & Maranhão & Lago Verde & $04026^{\prime} 00^{\prime \prime} \mathrm{s}$ & $44058^{\prime} 00^{\prime \prime}$ & -.. & Anderson A. & 2079 & 3/22/8: \\
\hline Croton palanostigma Klotzsch & Mameleiro & INPA & 64544 & 4 Brasil & Mato Grosso & Aripuanã & -.. & -- & -.. & Gomes $\mathrm{M}$. & 459 & 12/29/71 \\
\hline Croton palanostigma Klotzsch & -.- & $\mathrm{RB}$ & 158852 & 2 Brasil & Mato Grosso & Jurvema & -.. & -- & -.. & F.C.Hoehne & 5221 & $00 / 12 / 191$ \\
\hline Croton palanostigma Klotzsch & --- & $\mathrm{RB}$ & 158851 & 1 Brasil & Mato Grosso & Jurvema & -.- & -- & -.- & F.C.Hoehne & 5250 & $00 / 12 / 191$ \\
\hline Croton palanostigma Klotzsch & -- & $\mathrm{RB}$ & 99956 & 6 Brasil & Mato Grosso & Jurvema & $\cdots$ & -- & $\cdots$ & F.C.Hoehne & 5249 & 00/01/191: \\
\hline Croton palanostigma Klotzsch & -.. & $\mathrm{RB}$ & 99950 & 0 Brasil & Mato Grosso & Jurvema & -.- & -.- & -.. & F.C.Hoehne & 5220 & $00 / 12 / 191$ \\
\hline Croton palanostigma Klotzsch & -.- & $\mathrm{RB}$ & 158849 & 9 Brasil & Mato Grosso & Rio Acima & -.. & -- & -.. & J.G.Kuhlmann & 681 & $00 / 12 / 191$ ، \\
\hline Croton palanostigma Klotzsch & --- & $\mathrm{RB}$ & 99935 & 5 Brasil & Mato Grosso & Rio Animos & -.- & -- & -.- & J.G.Kuhlmann & 680 & $00 / 12 / 191$ ، \\
\hline Croton palanostigma Klotzsch & -- & $\mathrm{RB}$ & 158850 & 0 Brasil & Mato Grosso & Rio Primos & $\cdots$ & -- & $\cdots$ & J.G.Kuhlmann & 682 & $00 / 12 / 191$ \\
\hline Croton palanostigma Klotzsch & -.- & MG & 11458 & 8 Brasil & Pará & (Alto Arizamba N.E. & $02020^{\circ} 00^{\prime \prime} \mathrm{s}$ & $55045^{\prime} 00^{\prime \prime}$ & -.- & Ducke A. & $\mathrm{sn}$ & $12 / 17 / 11$ \\
\hline Croton palanostigma Klotzsch & --- & HEO & 96345 & 5 Brasil & Pará & (Região Ariramba*) & $02020^{\circ} 00^{\prime \prime} \mathrm{s}$ & $55045^{\prime} 00^{\prime \prime}$ & -.- & Black G. & 57-19914 & 6/8/5 \\
\hline Croton palanostigma Klotzsch & --- & MG & 22403 & 3 Brasil & Pará & (R. Cuminá Mirim ôbido) & $02020^{\circ} 00^{\prime \prime} \mathrm{s}$ & $55045^{\prime} 00^{\prime \prime}$ & -.- & Cavalcante $P$. & 188 & 6/9/5 \\
\hline Croton palanostigma Klotzsch &.-- & HEO & 91750 & 0 Brasil & Pará & (Serra do Cachimbo) & $02020^{\circ} 00^{\prime \prime} \mathrm{s}$ & $55045^{\prime} 00^{\prime \prime}$ & & 425 Pires J. & 6345 & 12/16/5 \\
\hline Croton palanostigma Klotzsch & -.- & UEC & 5140 & 0 Brasil & Pará & Curúa & -.. & -- & & 300 G.T.Prance et al. & 24864 & $11 / 5 / 7^{\prime}$ \\
\hline Croton palanostigma Klotzsch & $\ldots$ & HEO & 33085 & 5 Brasil & Pará & Fordlândia & -.- & --- & -.. & Black G. & $48-2329$ & 1/6/4: \\
\hline Croton palanostigma Klotzsch & -.- & HEO & 136925 & 5 Brasil & Pará & Ilha Mosqueiro & -.- & -- & -.- & Oliveira E. & 5933 & $10 / 18 / 7^{\prime}$ \\
\hline Croton palanostigma Klotzsch & -.- & MG & 92559 & 9 Brasil & Pará & Oriximiná & $01003^{\prime} 00^{\prime \prime} \mathrm{s}$ & $57003^{\prime} 00^{\prime \prime}$ & & 80 Martinelli G. & 6928 & 6/8/81 \\
\hline Croton palanostigma Klotzsch & -.- & MG & 61615 & 5 Brasil & Pará & Oriximiná & $01003^{\prime} 00^{\prime \prime} \mathrm{s}$ & $57003^{\prime} 00^{\prime \prime}$ & & 80 Silva $\mathrm{N}$. & 4650 & 5/27/7: \\
\hline Croton palanostigma Klotzsch & -.- & INPA & 94229 & 9 Brasil & Pará & Oriximiná & $01003^{\prime} 00^{\prime \prime} \mathrm{s}$ & $57003^{\prime} 00^{\prime \prime}$ & & $80 \mathrm{Cid} \mathrm{C}$. & 1037 & $6 / 18 / 81$ \\
\hline Crotonpalanostigma Klotzsch & -.- & HEO & 163820 & 0 Brasil & Pará & Paragominas & -.. & -.- & -.. & Cordeiro $\mathrm{M}$. & 2068 & $4 / 10 / 9$ \\
\hline Croton palanostigma Klotzsch & -.- & MG & 53466 & 6 Brasil & Pará & Santarém & -.. & -- & & 340 Kirkbride J. & 2775 & $2 / 14 / 7^{\prime}$ \\
\hline Crotonpalanostigma Klotzsch & -.- & MG & 59494 & 4 Brasil & Pará & Santarém & -.- & -- & & 0.5 Prince G. & 24864 & $11 / 5 / 7^{\prime}$ \\
\hline Croton palanostigma Klotzsch & -.- & MG & 118258 & 8 Brasil & Pará & Santarém & -.- & --- & & 40 Kirkbride J. & 2775 & $2 / 14 / 7$ \\
\hline Croton palanostigma Klotzsch & --- & HEO & 158454 & 4 Brasil & Pará & Tucumã & -.- & -- & -.- & Ribeiro J. & 70 & $11 / 17 / 8$ \\
\hline Croton palanostigma Klotzsch & -.- & MG & 87359 & 9 Brasil & Rondônia & Guajara-Mirim & -- & -.- & -.. & CarreiraL. & 463 & $2 / 1 / 8$ \\
\hline Crotonpalanostigma Klotzsch & $\ldots$ & MG & 156143 & 3 Brasil & Rondônia & Machadinho & $\ldots$ & .-. & $\ldots$ & Lobato $\mathrm{L}$. & 2061 & $11 / 8 / 9^{\prime}$ \\
\hline
\end{tabular}




\begin{tabular}{|c|c|c|c|c|c|c|c|c|c|c|c|c|c|}
\hline \multirow{2}{*}{$\begin{array}{l}\text { Espécie } \\
\text { N.científico }\end{array}$} & \multirow[b]{2}{*}{ N. vulgar } & \multicolumn{3}{|c|}{ Herbário } & \multicolumn{2}{|l|}{ Localidade } & \multirow[b]{2}{*}{ Município } & \multirow[b]{2}{*}{$\begin{array}{l}\text { Latitude } \\
\text { (oS.S) }\end{array}$} & \multirow[b]{2}{*}{$\begin{array}{c}\text { Longitude } \\
\text { (oS. W) }\end{array}$} & \multirow[b]{2}{*}{$\begin{array}{r}\text { Altitude } \\
(\text { manm) }\end{array}$} & COLETOR & \multirow{2}{*}{\multicolumn{2}{|c|}{ Data }} \\
\hline & & Sigla & Registro & & País & Estado & & & & & e Nome/número & & \\
\hline Crotonpalanostigma Klotzsch & -- & MG & & 74957 & Brasil & Rondônia & Pimenta Bueno & $12045^{\circ} 00^{\prime \prime} \mathrm{S}$ & $60010^{\circ} 00^{\prime \prime}$ & --- & Vieria M. & 989 & $11 / 7 / 7$ \\
\hline Crotonpalanostigma Klotzsch & -- & HEO & & 161104 & Brasil & Rondônia & Porto Velho & 09000'00"s & $62044^{\prime} 05^{\prime \prime}$ & & 115 Silva M. & 463 & $2 / 1 / 8$ \\
\hline Crotonpalanostigma Klotzsch & -- & MG & & 64508 & Brasil & Rondônia & Vilhena & $12045^{\prime} 00^{\prime \prime} \mathrm{S}$ & $60010^{\circ} 00^{\prime \prime}$ & --- & Silva M. & 4177 & $1 / 6 / 7$ \\
\hline Crotonpalanostigma Klotzsch & -- & MG & & 142593 & Brasil & Roraima & - & $00025^{\circ} 00^{\prime \prime} \mathrm{N}$ & $60020^{\circ} 00^{\prime \prime}$ & --. & Cordeiro I. & 34 & 6/15/8: \\
\hline Crotonpalanostigma Klotzsch & -- & SP & & 252868 & Brasil & Roraima & - & $00025^{\circ} 00^{\prime \prime} \mathrm{N}$ & $60020^{\circ} 00^{\prime \prime}$ & --- & I.Cordeiro et al. & 34 & 6/15/8: \\
\hline Crotonpalanostigma Klotzsch & -. & MG & & 73284 & Brasil & Roraima & (Marco divisor 10) & $03024^{\circ} 00^{\prime \prime} \mathrm{N}$ & $6102600^{\prime \prime}$ & & 700 Rosa N. & 3260 & 9/4/77 \\
\hline Crotonpalanostigma Klotzsch & -- & INPA & & 85060 & Brasil & Roraima & R.Uraricoera/S.curacinha & --- & $6303100 "$ & & 600 Pires J. & 16943 & $3 / 11 / 7$ \\
\hline Crotonpalanostigma Klotzsch & Maravuvuiarana & HEO & & 146038 & Brasil & Roraima & Surucucu & $02053^{\circ} 00^{\prime \prime} \mathrm{N}$ & $6303600^{\prime \prime}$ & --. & Rosa N. & 324 & $1 / 31 / 7$ \\
\hline Crotonpalanostigma Klotzsch & -- & HEO & & 145630 & Brasil & Roraima & Surucucu & $02053^{\circ} 00^{\prime \prime} \mathrm{N}$ & $6303600^{\prime \prime}$ & --- & Ribeiro B. & 15216 & $1 / 31 / 7$ \\
\hline Crotonpalanostigma Klotzsch & -- & HEO & & 143577 & Brasil & Roraima & Xeriuiri & --- & -- & --- & Pires J. & 13928 & $4 / 15 / 7$ \\
\hline Crotonpalanostigma Klotzsch & & $\mathrm{N}$ & $* * * *$ & & Guiana Fran. & Saül & - & $03037^{\circ} 00^{\prime \prime} \mathrm{N}$ & $53012^{2} 00^{\prime \prime}$ & & 300 S.A.Mori et al. 24778 & & 2/14/9; \\
\hline Crotonpalanostigma Klotzsch & & $\mathrm{N}$ & $* * *$ & & Guiana Fran. & Saül & - & 03037'00"N & $53013^{\circ} 00^{\prime \prime}$ & & 300 S.A.Mori et al. 15388 & & 3/26/8: \\
\hline Crotonpalanostigma Klotzsch & Sangre de grado & USM & & 25049 & Peru & Huánuco & Huánuco & -.- & -- & -.- & Ferrevra R. & 10204 & 9/23/5 \\
\hline Crotonpalanostigma Klotzsch & -- & MG & & 7483 & Peru & Loreto & Mavnas & $03020^{\prime} 00^{\prime \prime S}$ & $72055^{\circ} 00^{\prime \prime}$ & & 120 Ducke A. & sn & $7 / 21 / 0$ \\
\hline Crotonpalanostigma Klotzsch & -- & MG & & 113089 & Peru & Loreto & Mavnas & $0302000 " \mathrm{~S}$ & $72055^{\circ} 00^{\prime \prime}$ & & 120 Gentry A. & 21741 & 5/12/7: \\
\hline Crotonpalanostigma Klotzsch & -- & AMAZ & & 13058 & Peru & Loreto & Mavnas & $03020^{\prime} 00^{\prime \prime S}$ & $72055^{\circ} 00^{\prime \prime}$ & & 120 Gentry A. & 22288 & 5/26/7: \\
\hline Crotonpalanostigma Klotzsch & -- & AMAZ & & 15667 & Peru & Loreto & Mavnas & $0302000 " \mathrm{~s}$ & $72055^{\circ} 00^{\prime \prime}$ & & 120 Arévalo E. & 81 & 1/22/8 \\
\hline Crotonpalanostigma Klotzsch & -- & AMAZ & & 3224 & Peru & Loreto & Mavnas & $03020^{\prime} 00^{\prime \prime S}$ & $72055^{\circ} 00^{\prime \prime}$ & & 120 Rimachi M. & 747 & $1 / 2377$ \\
\hline Crotonpalanostigma Klotzsch & $\ldots$ & AMAZ & & 26017 & Peru & Loreto & Mavnas & $03020^{\prime} 00^{\prime \prime S}$ & $72055^{\circ} 00^{\prime \prime}$ & & 120 Ruiz J. & 11 & $2 / 777$ \\
\hline Crotonpalanostigma Klotzsch & -- & AMAZ & & 531 & Peru & Loreto & Mavnas & $05003^{\prime} 03^{\prime \prime S}$ & 74012'05" & & 100 Avala F. & 531 & 2/28/7 \\
\hline Crotonpalanostigma Klotzsch & -- & AMAZ & & 2541 & Peru & Loreto & Mavnas & $03020^{\prime} 00^{\prime \prime S}$ & $72055^{\circ} 00^{\prime \prime}$ & & 120 Gentry A. & 16549 & 7/9/7 \\
\hline Crotonpalanostigma Klozsch & & USM & & 150630 & Peru & Loreto & Mavnas & $0302000 " \mathrm{~S}$ & $72055^{\circ} 00^{\prime \prime}$ & & 120 Pipolv J. et al. & 14028 & 3/2/9 \\
\hline Crotonpalanostigma Klotzsch & & USM & & 134532 & Peru & Loreto & Mavnas & $03020^{\prime} 00^{\prime \prime S}$ & $72055^{\circ} 00^{\prime \prime}$ & & 120 Pipolv J. et al. & 13803 & $2 / 25 / 9$ \\
\hline Crotonpalanostigma Klotzsch & Shasnoquiro & USM & & 129023 & Peru & Loreto & Mavnas & $03020^{\prime} 00^{\prime \prime} \mathrm{S}$ & $72055^{\circ} 00^{\prime \prime}$ & & 120 Rimachi M. & 11909 & $6 / 11 / 9^{\prime}$ \\
\hline Crotonpalanostigma Klotzsch & & USM & & 97442 & Peru & Loreto & Mavnas & 03055'00"S & 7303500" & & 130 Vásauez R. et al. & 5412 & $7 / 25 / 8$ \\
\hline Crotonpalanostigma Klotzsch & & USM & & 94535 & Peru & Loreto & Mavnas & $03020^{\prime} 00^{\prime \prime S}$ & $72055^{\circ} 00^{\prime \prime}$ & & 120 Rimachi M. & 7382 & $2 / 16 / 8$ \\
\hline Croton palanostigma Klotzsch & & USM & & 52211 & Peru & Loreto & Mavnas & $03020^{\circ} 00^{\prime \prime} \mathrm{s}$ & $72055^{\circ} 00^{\prime \prime}$ & & 120 Gentry A. & 16549 & 7/9/7 \\
\hline Crotonpalanostigma Klotzsch & Sangre de grado & AMAZ & & 6410 & Peru & Loreto & Ramón Castilla & --- & - & --- & Avala F. & 2420 & $11 / 26 / 7$ \\
\hline Crotonpalanostigma Klotzsch & & USM & & 63691 & Peru & Loreto & Reauena & $05014^{\prime} 00^{\prime \prime S}$ & $73053^{\circ} 00^{\prime \prime}$ & & 115 Macrae D. & 76 & $4 / 26 / 8$ \\
\hline Crotonpalanostigma Klotzsch & & USM & sn & & Peru & San Martín & Mariscal Cáceres & 0801500"S & 76031'00" & & 510 Plawman $T$. & sn & $12 / 16 / 8$ \\
\hline Crotonpalanostigma Klotzsch & Sangre de grado & USM & & 156470 & Peru & San Martín & Mariscal Cáceres & $08015^{\prime} 00^{\prime \prime} \mathrm{S}$ & $76031^{100 "}$ & & 510 Schunke V.J. & 8460 & 5/11/7: \\
\hline
\end{tabular}


Informação do material botânico nos herbários do gênero Uncaria

\begin{tabular}{|c|c|c|c|c|c|c|c|c|c|c|c|c|}
\hline \multirow{2}{*}{$\begin{array}{l}\text { Espécie } \\
\text { N.científico }\end{array}$} & \multirow[b]{2}{*}{ N. vulgar } & \multicolumn{2}{|l|}{ Herbário } & \multicolumn{3}{|c|}{ Localidade } & \multirow[b]{2}{*}{$\begin{array}{c}\text { Latitude } \\
\text { (oS.S. S) } \\
\end{array}$} & \multirow[b]{2}{*}{$\begin{array}{r}\text { Longitude } \\
\left({ }^{\circ} \mathrm{S}, \mathrm{W}\right) \\
\end{array}$} & \multirow[b]{2}{*}{$\begin{array}{l}\text { Altitud } \\
\text { (manm }\end{array}$} & \multicolumn{2}{|l|}{ COLETOR } & \\
\hline & & Sigla & Registro & País & Estado & Município & & & & $\begin{array}{l}\text { le Nome/número } \\
\text { 1) }\end{array}$ & & \\
\hline Uncaria guianensis & & мо & $* * *$ & Bolívia & Beni & $-\ldots$ & $01000^{\prime} 00^{\prime \prime} \mathrm{S}$ & $66004^{\prime} 00^{\prime \prime}$ & & 170 J.C. Salomon 16786 & & $5 / 25 / 87$ \\
\hline Uncaria guianensis & & мо & $* * *$ & Bolívia & Beni & 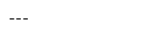 & $11002^{\prime} 00 " \mathrm{~S}$ & $66006^{\circ} 00^{\prime \prime}$ & & 230 J.C.Salomon 7657 & & $5 / 17 / 82$ \\
\hline Uncaria guianensis & & LPB & $* * *$ & Bolívia & Beni & -- & -- & & -- & G. Beck 16329 & & $5 / 24 / 88$ \\
\hline Uncaria guianensis &.-- & HUNB & $\mathrm{sn}$ & Bolívia & Beni & -.. & -.- & -.. & & 180 Acevedo R.P. et al. & 6665 & 29/07/1994 \\
\hline Uncaria guianensis & Cacatao & MG & 106990 & Bolívia & Beni & -.. & $11045^{\prime} 00^{\prime \prime} \mathrm{S}$ & $66022^{\prime} 00^{\prime \prime}$ & & $200 \mathrm{~s} / \mathrm{c}$ & $\mathrm{sn}$ & $3 / 31 / 84$ \\
\hline Uncaria guianensis & -.. & HUNB & sn & Bolívia & Beni & Ballivián & $14030^{\circ} 00^{\prime S} \mathrm{~s}$ & $67037^{\circ} 00^{\prime \prime}$ & & 200 Davis E.W. et al. & sn & $3 / 6 / 81$ \\
\hline Uncaria guianensis & Uña de gato & HUNB & sn & Bolívia & Beni & Ballivián & $14030^{\prime} 00^{\prime \prime} \mathrm{S}$ & $67037^{\circ} 00^{\prime \prime}$ & & 200 Rivero E. & 435 & 20/06/1995 \\
\hline Uncaria guianensis & $\ldots$ & HUNB & sn & Bolívia & Beni & Ballivián & $14030^{\circ} 00^{\prime \prime} \mathrm{S}$ & $67037^{\circ} 00^{\prime \prime}$ & & 200 Beck G. et al. & 16329 & $25 / 05 / 1988$ \\
\hline Uncaria guianensis & -- & HUNB & sn & Bolívia & Beni & Ballivián & $14030^{\circ} 00^{\prime \prime} \mathrm{S}$ & $66027^{\circ} 00^{\prime \prime}$ & & 200 Cerón C.E. & 16176 & $26 / 08 / 1991$ \\
\hline Uncaria guianensis & -- & HUNB & sn & Bolívia & Beni & Vaca Diez & $11005^{\prime} 00 " \mathrm{~S}$ & $65050^{\prime} 00^{\prime \prime}$ & $\cdots$ & Salomon J.C. & 6282 & $17 / 09 / 1981$ \\
\hline Uncaria guianensis & Cacatao & HUNB & sn & Bolívia & Beni & Vaca Diez & $11041^{\prime} 00^{\prime \prime} \mathrm{S}$ & $66002^{\prime} 00^{\prime \prime}$ & & 200 Boom B.M. & $\mathrm{sn}$ & $31 / 03 / 1984$ \\
\hline Uncaria guianensis & $\ldots$ & HUNB & sn & Bolívia & Beni & Vaca Diez & $11002^{\prime} 00^{\prime \prime} \mathrm{s}$ & $66006^{\circ} 00^{\prime \prime}$ & & 230 Salomon J.C. & 7657 & $17 / 05 / 1982$ \\
\hline Uncaria guianensis & -- & HUNB & sn & Bolívia & Beni & Vaca Diez & $11000^{\circ} 00^{\prime \prime} \mathrm{s}$ & $66004^{\prime} 00^{\prime \prime}$ & & 210 Michel R. de & $2143 \mathrm{~A}$ & $22 / 09 / 1993$ \\
\hline Uncaria guianensis & -- & HUNB & sn & Bolívia & Beni & Vaca Diez & $11000^{\circ} 00^{\prime \prime} \mathrm{S}$ & $66004^{\prime} 00^{\prime \prime}$ & & 170 Salomon J.C. & 16786 & $25 / 05 / 1987$ \\
\hline Uncaria guianensis & & мо & $* * *$ & Bolívia & Cochabamba & $\ldots-$ & $17000^{\circ} 00^{\prime \prime} \mathrm{s}$ & $64046^{\prime} 00^{\prime \prime}$ & & 235 D.N.Smith et al. 12944 & & $4 / 25 / 89$ \\
\hline Uncaria guianensis & & usz & $* * *$ & Bolívia & Cochabamba & -.. & $17006^{\circ} 00^{\prime \prime} \mathrm{s}$ & $64046^{\circ} 00^{\prime \prime}$ & & 256 J.A.Carrasco et al. 14 & & sd \\
\hline Uncaria guianensis &.-- & HUNB & $\mathrm{sn}$ & Bolívia & Cochabamba & Carrasco & $17000^{\circ} 00^{\prime \prime} \mathrm{S}$ & $64046^{\circ} 00^{\prime \prime}$ & & 235 Quintana G. et al. & 12944 & $25 / 04 / 1989$ \\
\hline Uncaria guianensis & Uña de gato & HUNB & sn & Bolívia & Cochabamba & Chaparé & $10045^{\prime} 00 " \mathrm{~S}$ & $64045^{\prime} 00^{\prime \prime}$ & & 40 Naessany L.N. & 44 & 29/04/1989 \\
\hline Uncaria guianensis & --- & HUNB & sn & Bolívia & Cochabamba & Chaparé & $10045^{\prime} 00^{\prime S}$ & $64045^{\prime} 00^{\prime \prime}$ & & 40 Ibisch & 960055 & $00 / 00 / 1996$ \\
\hline Uncaria guianensis & & мо & $* * *$ & Bolívia & La Paz & $\ldots$ & $14036^{\prime} 42^{\prime \prime S}$ & $67039^{\circ} 04^{\prime \prime}$ & & 290 Dela Quintana et al. 511 & & $2 / 10 / 02$ \\
\hline Uncaria guianensis & & мо & $* * *$ & Bolívia & La Paz & -.. & -.- & & & $300 \mathrm{Al}$ Gentry et al. 70209 & & $5 / 20 / 90$ \\
\hline Uncaria guianensis & & usz & $* * *$ & Bolívia & La Paz & Buena Vista & $14022^{\prime} 00 " \mathrm{~S}$ & $67033^{\prime} 00^{\prime \prime}$ & & 180 S. Dewalt et al. 112 & & 4/14/95 \\
\hline Uncaria guianensis &.-- & HUNB & sn & Bolívia & La Paz & Iturralde & $14022^{\prime} 00^{\prime \prime} \mathrm{S}$ & $67033^{\prime} 00^{\prime \prime}$ & & 180 Dewalt S. et al. & 248 & $21 / 04 / 1995$ \\
\hline Uncaria guianensis & & мо & $* * *$ & Bolívia & La Paz & Madidi & 14036 '52"S & 67039'11" & & 220 Dela Quintana et al $435 \mathrm{~A}$ & & 2/8/02 \\
\hline Uncaria guianensis & -- & HUNB & sn & Bolívia & $\mathrm{LaPaz}$ & Nor Yungas & $16003^{\prime} 00 " \mathrm{~s}$ & $67040^{\prime} 00^{\prime \prime}$ & & 1000 Persson C. et al & 2002 & 7/9/96 \\
\hline Uncaria guianensis & -- & HUNB & sn & Bolívia & La Paz & Sud Yungas & 161300 & 674700 & & 825 Krufoff B. ${ }^{a}$ & 10313 & $1 / 22 / 39$ \\
\hline Uncaria guianensis & -- & HUNB & sn & Bolívia & La Paz & Sud Yungas & 161300 & 674700 & & 500 Beck G. & 13303 & $28 / 03 / 1986$ \\
\hline Uncaria guianensis & -- & HUNB & sn & Bolívia & La Paz & Sud Yungas & 161300 & 674700 & & 890 Rea L. et al. & 27 & $5 / 8 / 91$ \\
\hline Uncaria guianensis &.-- & HUNB & sn & Bolívia & La Paz & Sud Yungas & 161300 & 674700 & -.- & Vargas G.I. & 2223 & 20/04/1989 \\
\hline Uncaria guianensis & & мо & $* * *$ & Bolívia & Pando & $\cdots$ & $11048^{\prime} 00^{\prime \prime} \mathrm{S}$ & $67017^{\prime} 00^{\prime \prime}$ & & 150 J. C. Solomon 16845 & & $6 / 1 / 87$ \\
\hline Uncaria guianensis & & usz & $* * *$ & Bolívia & Pando & -.. & $11044^{\prime} 00^{\prime \prime} \mathrm{S}$ & $67059^{\circ} 00^{\prime \prime}$ & & 200 A. Jardim 732 & & $5 / 13 / 93$ \\
\hline Uncaria guianensis & & usz & $* * *$ & Bolívia & Pando & -.. & $11016^{\prime} 03^{\prime \prime S}$ & $68044^{\prime} 06^{\prime \prime}$ & -.. & I.G.Vargas et al. 5229 & & $9 / 14 / 00$ \\
\hline Uncaria guianensis &.-- & INPA & 22610 & Bolívia & Pando & Madre de Dios & $12012^{\prime} 00^{\prime S}$ & $67027^{\circ} 00^{\prime \prime}$ & & 170 Prance G. & 5855 & $7 / 11 / 67$ \\
\hline Uncaria guianensis & -- & HUNB & sn & Bolívia & Pando & Madre de Dios & $11048^{\prime} 00^{\prime S} \mathrm{~S}$ & $67017^{\prime} 00^{\prime \prime}$ & & 150 Salomon J.C. & 16845 & $1 / 6 / 87$ \\
\hline Uncaria guianensis & Misi juni & HUNB & sn & Bolívia & Pando & Madre de Dios & $11048^{\prime} 00^{\prime \prime S}$ & $67017^{\prime} 00^{\prime \prime}$ & & 150 Serato $^{a}$ & sn & $6 / 2 / 95$ \\
\hline Uncaria guianensis & --- & MG & 146824 & Bolívia & Pando & Madre de Dios & $12012^{\prime} 00^{\prime \prime} \mathrm{S}$ & $67027^{\circ} 00^{\prime \prime}$ & & 170 Berk G. & 19548 & $10 / 20 / 89$ \\
\hline Uncaria guianensis & & usz & $* * *$ & Bolívia & Pando & Puerto América & $11044^{\prime} 00^{\prime \prime} \mathrm{S}$ & $67059^{\circ} 00^{\prime \prime}$ & & 220 A. Jardim 643 & & $5 / 2 / 94$ \\
\hline
\end{tabular}




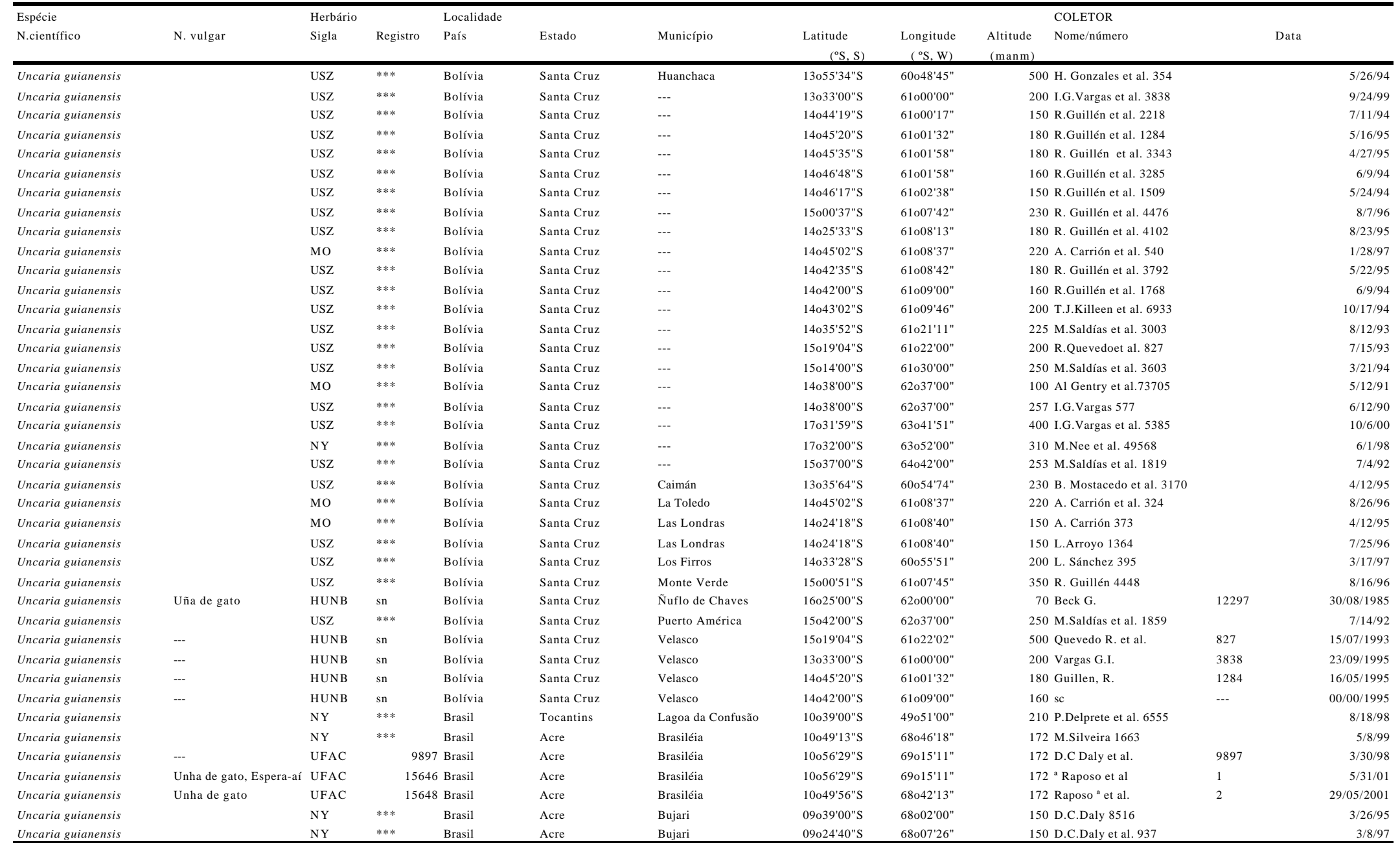




\begin{tabular}{|c|c|c|c|c|c|c|c|c|c|c|c|c|}
\hline $\begin{array}{l}\text { Espécie } \\
\text { N.científico }\end{array}$ & N. vulgar & $\begin{array}{l}\text { Herbário } \\
\text { Siggla }\end{array}$ & Registro & $\begin{array}{l}\text { Localidade } \\
\text { País }\end{array}$ & Estado & Município & $\begin{array}{l}\text { Latitude } \\
\quad\left({ }^{\circ}, S, S\right)\end{array}$ & $\begin{array}{c}\text { Longitude } \\
\left({ }^{\circ}, \mathrm{W}\right)\end{array}$ & $\begin{array}{r}\text { Altitude } \\
(\text { manm })\end{array}$ & $\begin{array}{ll}\text { COLETOR } \\
& \text { Nome/número } \\
\end{array}$ & & \\
\hline Uncaria guianensis & Cipó anzol de londra & UFAC & 4008 & Brasil & Acre & Bujari & $09024^{\prime} 40 " \mathrm{~S}$ & $68007^{\prime} 26 "$ & & 150 I.F. Rego et al & 948 & $2 / 14 / 92$ \\
\hline Uncaria guianensis & $\ldots$ & UFAC & sn & Brasil & Acre & Bujari & $09042 \cdot 53 " \mathrm{~S}$ & $68008^{\prime} 27 "$ & & 150 Raposo a et al. & 11 & $8 / 8 / 02$ \\
\hline Uncaria guianensis & Esperái & UFAC & 10435 & Brasil & Acre & Bujarí & $09024 ' 40 " \mathrm{~S}$ & $68007^{\prime} 26 "$ & & 150 D.C Daly et al. & 9371 & 3/8/97 \\
\hline Uncaria guianensis & Unha de gato & UFAC & 15640 & Brasil & Acre & Cruzeiro do Sul & $07038^{\prime} 00^{\prime S} \mathrm{~S}$ & $72036^{\prime} 00^{\prime \prime}$ & & 190 M.E. Melo et al & 6 & $8 / 3 / 00$ \\
\hline Uncaria guianensis & Unha de gato & UFAC & 15639 & Brasil & Acre & Cruzeiro do Sul & $07038^{\prime} 00 " \mathrm{~S}$ & $72036^{\circ} 00^{\prime \prime}$ & & 190 M.E. Melo et al & 5 & $8 / 2 / 00$ \\
\hline Uncaria guianensis & Unha de gato & UFAC & 15638 & Brasil & Acre & Cruzeiro do Sul & $07038^{\prime} 00 " \mathrm{~S}$ & $72036^{\prime} 00^{\prime \prime}$ & & 190 M.E. Melo et al & 4 & $8 / 3 / 00$ \\
\hline Uncaria guianensis & -.. & UFAC & sn & Brasil & Acre & Plácido Castro & $10018^{\prime} 40 " \mathrm{~S}$ & $67031^{\prime 30 "}$ & & 136 Raposo "et al. & 13 & 13/08/2002 \\
\hline Uncaria guianensis & Unha de gato, Cipô & UFAC & 13575 & Brasil & Acre & Rio Branco & $09058^{\prime} 00 " \mathrm{~S}$ & $67048^{\prime} 00^{\prime \prime}$ & & 153 FUNDAC & 263 & sd \\
\hline Uncaria guianensis & $\ldots$ & UFAC & 646 & Brasil & Acre & Rio Branco & $09058^{\prime} 00 " \mathrm{~S}$ & $67048^{\prime} 00^{\prime \prime}$ & & 153 C.D. Mota \& S. Santos & 47 & 9/28/83 \\
\hline Uncaria guianensis & Unha de gato & INPA & 10980 & Brasil & Acre & Rio Branco & $09058^{\prime} 00 " \mathrm{~S}$ & $67048^{\prime} 00^{\prime \prime}$ & & 153 Vasconcelos D. & $\mathrm{s} / \mathrm{n}$ & $2 / 12 / 62$ \\
\hline Uncaria guianensis & $\ldots$ & MG & 4657 & Brasil & Acre & Santa Rosa do Purus & $09027^{\prime} 00^{\prime \prime S}$ & $70032^{\prime} 00^{\prime \prime}$ & --- & Hublos J. & 4657 & $4 / 23 / 04$ \\
\hline Uncaria guianensis & & NY & $* * *$ & Brasil & Acre & Sena Madureira & $09043^{\prime} 45^{\prime \prime S}$ & $68008^{\prime} 53^{\prime \prime}$ & & 150 S.Oliveira et al. 515 & & 6/8/95 \\
\hline Uncaria guianensis & & NY & $* * *$ & Brasil & Acre & Sena Madureira & $09004^{\circ} 00^{\prime S} \mathrm{~S}$ & $68037^{\circ} 00^{\prime \prime}$ & & 150 G.T.Prance et al. 7781 & & $10 / 3 / 68$ \\
\hline Uncaria guianensis & & NY & ***** & Brasil & Acre & Sena Madureira & $090_{0} 12^{\prime} 00 " \mathrm{~S}$ & $68044^{\prime} 00^{\prime \prime}$ & & 150 D.C.Daly et al. 8186 & & 4/4/94 \\
\hline Uncaria guianensis & Esperái & UFAC & 6780 & Brasil & Acre & Sena madureira & $09012^{\prime} 00 " \mathrm{~S}$ & $68044^{\prime} 00^{\prime \prime}$ & & 150 D.C Daly et al. & 18186 & $10 / 21 / 02$ \\
\hline Uncaria guianensis & Ansou de londra & UFAC & 13807 & Brasil & Acre & Sena Madureira & $09020^{\prime} 00^{\prime \prime}$ & $68030^{\circ} 00^{\prime \prime}$ & & 150 F.C.S. Walthier & 124 & 6/8/93 \\
\hline Uncaria guianensis & --- & INPA & 24579 & Brasil & Acre & Sena Madureira & $09_{0} 12^{\prime} 00 " \mathrm{~S}$ & $68044^{\prime} 00^{\prime \prime}$ & & 150 Prince G. & 7781 & $10 / 3 / 68$ \\
\hline Uncaria guianensis & Unha de gato & UFAC & sn & Brasil & Acre & Senador Guiomar & $10005^{\prime} 188^{\prime S}$ & $670344^{55 "}$ & & 201 Raposo a et al. & 12 & 9/8/02 \\
\hline Uncaria guianensis & $\ldots$ & $\mathrm{MG}$ & 57523 & Brasil & Acre & Tarauacá & $08021^{\prime} 04 " \mathrm{~S}$ & 70o44'43" & & 168 Mota C. & 306 & $4 / 5 / 76$ \\
\hline Uncaria guianensis & & NY & **** & Brasil & Acre & Xapuri & $10046 \cdot 42 " \mathrm{~S}$ & $68013^{\prime} 52^{\prime \prime}$ & & 150 D.C.Daly et al. 8400 & & 3/19/95 \\
\hline Uncaria guianensis & Unha de gato & UFAC & 6514 & Brasil & Acre & Xapuri & $10046 \cdot 42 " \mathrm{~S}$ & $68013^{\prime} 52^{\prime \prime}$ & & 150 Ming, L.C. et al. & 382 & $2 / 3 / 94$ \\
\hline Uncaria guianensis & Unha de gato & UFAC & 9801 & Brasil & Acre & Xapuri & $10046^{\prime} 42 " \mathrm{~S}$ & $68013^{\prime} 52^{\prime \prime}$ & & 150 D.C Daly et al. & sn & 3/19/95 \\
\hline Uncaria guianensis & -.. & INPA & 92574 & Brasil & Acre & Xapuri & $10046^{\prime} 42 " \mathrm{~S}$ & 68013'52" & & 150 Coelho L. & 1691 & $6 / 5 / 80$ \\
\hline Uncaria guianensis & -.- & $\mathrm{SP}$ & 57109 & Brasil & Amapá & Macapá & $01047^{\prime} 00^{\prime \prime} \mathrm{N}$ & $51058^{\prime} 00^{\prime \prime}$ & & R.L. Fróes \& G.A Black & 27552 & $7 / 22 / 51$ \\
\hline Uncaria guianensis & ... & HEO & 64377 & Brasil & Amapá & Macapá & $01047^{\prime} 00^{\prime \prime} \mathrm{N}$ & $51058^{\prime} 00^{\prime \prime}$ & -.- & Froes $\mathrm{R}$. & 27366 & $7 / 10 / 51$ \\
\hline Uncaria guianensis & $\ldots$ & HEO & 64554 & Brasil & Amapá & Macapá & $01047^{\prime} 00^{\prime \prime} \mathrm{N}$ & $51058^{\prime} 00^{\prime \prime}$ & -.- & Froes $\mathrm{R}$. & 27552 & $7 / 22 / 51$ \\
\hline Uncaria guianensis & -.- & HEO & 64359 & Brasil & Amapá & Macapá & $01047^{\prime} 00^{\prime \prime} \mathrm{N}$ & $51058^{\prime} 00^{\prime \prime}$ & --. & Froes $\mathrm{R}$. & 27347 & $7 / 8 / 51$ \\
\hline Uncaria guianensis & Mão-de-gato & MG & 29597 & Brasil & Amapá & Macapá & $01047^{\prime} 00^{\prime \prime} \mathrm{N}$ & $51058^{\prime} 00^{\prime \prime}$ & --. & Murça J. & 52293 & $7 / 26 / 62$ \\
\hline Uncaria guianensis & $\ldots$ & MG & 28098 & Brasil & Amapá & Macapá & $01036^{\prime} 00 " \mathrm{~N}$ & $51058^{\prime} 00^{\prime \prime}$ & .-. & Pires J. & 50749 & 9/7/61 \\
\hline Uncaria guianensis & Jupindá & MG & 81408 & Brasil & Amapá & Macapá & $01036^{\prime} 00^{\prime \prime} \mathrm{N}$ & $51058^{\prime} 00^{\prime \prime}$ & --- & Rabelo B. & 901 & $10 / 25 / 80$ \\
\hline Uncaria guianensis & $\ldots$ & HEO & 172520 & Brasil & Amazonas & Alvaraens & ..- & -.- & --. & Jamber Ch. & 2 & $2 / 24 / 96$ \\
\hline Uncaria guianensis & $\ldots$ & HEO & 172522 & Brasil & Amazonas & Alvaraens & -.- & -.. & --. & Jamber Ch. & 6 & $2 / 24 / 96$ \\
\hline Uncaria guianensis & --- & HEO & 172521 & Brasil & Amazonas & Alvaraens & -.- & -.- & --- & Jamber Ch. & 7 & 2/24/96 \\
\hline Uncaria guianensis & -.- & $\mathrm{RB}$ & 15693 & Brasil & Amazonas & Boca do Acre & $08040^{\circ} 00^{\prime S} \mathrm{~S}$ & $67022^{\prime} 00^{\prime \prime}$ & & Y. Huber & sn & $4 / 23 / 04$ \\
\hline Uncaria guianensis & -.- & UFAC & 16055 & Brasil & Amazonas & Boca do Acre & $08040^{\circ} 00^{\prime S} \mathrm{~S}$ & $67022^{\prime} 00^{\prime \prime}$ & --. & Silva J.M.M. et al. & sn & 20/09/2001 \\
\hline Uncaria guianensis & -.- & MG & 125764 & Brasil & Amazonas & Borba & $06050^{\circ} 00^{\prime \prime S}$ & $59000^{\prime} 00^{\prime \prime}$ & --- & Henderson A. & 427 & $5 / 9 / 85$ \\
\hline Uncaria guianensis & ... & INPA & 58216 & Brasil & Amazonas & Coari & ... & -.- & .-. & Motta G. & 246 & $4 / 24 / 76$ \\
\hline Uncaria guianensis & -.. & INPA & 211205 & Brasil & Amazonas & Coari & -.. & -.. & -.- & Cid C. & 12221 & $10 / 10 / 01$ \\
\hline Uncaria guianensis & --- & MG & 191138 & Brasil & Amazonas & Esperança & -.- & -.- & --- & Ducke A. & 1125 & $9 / 24 / 42$ \\
\hline Uncaria guianensis & Unha de gato & INPA & 95509 & Brasil & Amazonas & Huamaitá & $07031^{\prime} 00 " \mathrm{~S}$ & $63010^{\prime} 00^{\prime \prime}$ & & 0.7 Jenssen A. & 267 & $4 / 17 / 80$ \\
\hline
\end{tabular}




\begin{tabular}{|c|c|c|c|c|c|c|c|c|c|c|c|c|}
\hline \multirow{2}{*}{$\begin{array}{l}\text { Espécie } \\
\text { N.científico }\end{array}$} & \multirow[b]{2}{*}{ N. vulgar } & \multicolumn{2}{|l|}{ Herbário } & \multicolumn{2}{|l|}{ Localidade } & \multirow[b]{2}{*}{ Município } & \multirow[b]{2}{*}{$\begin{array}{l}\text { Latitude } \\
\quad\left({ }^{\circ} \mathrm{S}, \mathrm{S}\right)\end{array}$} & \multirow[b]{2}{*}{$\begin{array}{c}\text { Longitude } \\
\left({ }^{\circ}, \mathrm{W}\right)\end{array}$} & \multirow[b]{2}{*}{$\begin{array}{l}\text { Altitude } \\
\text { (manm) }\end{array}$} & \multicolumn{3}{|l|}{ COLETOR } \\
\hline & & Sigla & Registro & País & Estado & & & & & Nome/número & & \\
\hline Uncaria guianensis & $\ldots$ & INPA & 87799 & Brasil & Amazonas & Itapiranga & $\ldots$ & $\ldots$ & --- & Cid C. & 363 & $8 / 16 / 79$ \\
\hline Uncaria guianensis & --- & INPA & 87171 & Brasil & Amazonas & Itapiranga & -.- & --. & $\ldots$ & Cid C. & 675 & $8 / 24 / 79$ \\
\hline Uncaria guianensis & --- & MG & 70426 & 6rasil & Amazonas & Itapiranga & $\cdots$ & -- & -- & Ferreira C. & 903 & $8 / 28 / 79$ \\
\hline Uncaria guianensis & --- & MG & 70323 & 3 Brasil & Amazonas & Itapiranga & -.- & -.- & -.. & Cid C. & 675 & $8 / 24 / 79$ \\
\hline Uncaria guianensis & --- & INPA & 35990 & Brasil & Amazonas & Janauacá & -.- & --. & -.. & Honda $\mathrm{M}$. & $\mathrm{s} / \mathrm{n}$ & $6 / 5 / 72$ \\
\hline Uncaria guianensis & --- & INPA & 35990 & Brasil & Amazonas & Januacá-Lago do $\mathrm{C}$ & o--- & --- & -- & Honda $\mathrm{M}$. & $\mathrm{s} / \mathrm{n}$ & $6 / 5 / 72$ \\
\hline Uncaria guianensis & --- & MG & 57424 & 4 Brasil & Amazonas & Lago de Copea & 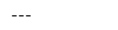 & -- & -- & Mello M. & sn & $4 / 24 / 76$ \\
\hline Uncaria guianensis & --- & INPA & 39146 & 6 Brasil & Amazonas & Manaus & $02019^{\prime} 00^{\prime \prime S}$ & $60005^{\prime} 00^{\prime \prime}$ & & 25 Alburquerque B. & 805 & $6 / 22 / 73$ \\
\hline Uncaria guianensis & --- & SPF & 71038 & Brasil & Amazonas & Manaus & $01027^{\prime} 00 " \mathrm{~S}$ & $61036^{\prime} 00^{\prime \prime}$ & & S, Mori et al. & 20403 & $6 / 6 / 89$ \\
\hline Uncaria guianensis & --- & $\mathrm{RB}$ & 24378 & B Brasil & Amazonas & Manaus & $02019^{\prime} 00^{\prime \prime S}$ & $60005^{\prime} 00^{\prime \prime}$ & & 25 'Ducke & sn & $5 / 10 / 32$ \\
\hline Uncaria guianensis & Unha de gato & INPA & 202737 & Brasil & Amazonas & Manaus & $02019^{\prime} 00 " \mathrm{~S}$ & $60005^{\prime} 00^{\prime \prime}$ & & 25 Coelho L. & 92 & $3 / 15 / 99$ \\
\hline Uncaria guianensis & --- & INPA & 12953 & Brasil & Amazonas & Manaus & $02019^{\prime} 00 " \mathrm{~S}$ & $60005^{\prime} 00^{\prime \prime}$ & & 25 Rodriguez W. & 4462 & $5 / 22 / 62$ \\
\hline Uncaria guianensis & -.- & INPA & 201830 & Brasil & Amazonas & Manaus & $02019^{\prime} 00^{\prime \prime S}$ & $60005^{\prime} 00^{\prime \prime}$ & 125 & 25 Anderson S. & $s / n$ & 10/9/99 \\
\hline Uncaria guianensis &.-- & INPA & 170388 & Brasil & Amazonas & Manaus & $01027^{\prime} 00^{\prime \prime S}$ & $61036^{\prime} 00^{\prime \prime}$ & -- & Mori S. & 20403 & $6 / 6 / 89$ \\
\hline Uncaria guianensis & -.- & MG & 13961 & Brasil & Amazonas & Manaus & $02019^{\prime} 00^{\prime \prime S}$ & $60005^{\prime} 00^{\prime \prime}$ & & 25 Ule E. & 8938 & $00 / 06 / 1910$ \\
\hline Uncaria guianensis & --- & $\mathrm{R}$ & 55931 & Brasil & Amazonas & Manaus & $000311^{\prime} 30^{\prime \prime} \mathrm{N}$ & 63029'30" & & "Ducke & 1125 & $9 / 24 / 42$ \\
\hline Uncaria guianensis & -.- & INPA & 126991 & Brasil & Amazonas & Manicoré & $08010^{\prime} 00^{\prime \prime S}$ & $61045^{\prime} 00^{\prime \prime}$ & -.- & Cid C. & 5527 & $4 / 15 / 85$ \\
\hline Uncaria guianensis & -- & INPA & 127289 & Brasil & Amazonas & Manicoré & $07035^{\prime} 00 " \mathrm{~S}$ & $60040^{\prime} 00^{\prime \prime}$ & -- & Cid C. & 5825 & $4 / 24 / 85$ \\
\hline Uncaria guianensis & --- & MG & 120236 & Brasil & Amazonas & Manicoré & $08010^{\circ} 00^{\prime S} \mathrm{~S}$ & $61045^{\prime} 00^{\prime \prime}$ & --. & Ferreira C. & 5527 & $4 / 15 / 85$ \\
\hline Uncaria guianensis & --- & $\mathrm{R}$ & 180339 & Brasil & Amazonas & Maraã & $01050^{\circ} 00^{\prime \prime S}$ & $65040^{\prime} 00^{\prime \prime}$ & & C. ${ }^{a}$ Cid \& J. Lima & 3485 & $11 / 3 / 82$ \\
\hline Uncaria guianensis & --- & MG & 102667 & Brasil & Amazonas & Marã̃ & $01050^{\circ} 00^{\prime \prime S}$ & $65040^{\circ} 00^{\prime \prime}$ & -.- & Cid C. & 3485 & $11 / 3 / 82$ \\
\hline Uncaria guianensis & -- & HRCB & 6965 & Brasil & Amazonas & Maricuré & $07035^{\circ} 00^{\prime \prime S}$ & $60040^{\prime} 00^{\prime \prime}$ & & C. ${ }^{a}$ Cid Ferreira & 5825 & $4 / 24 / 85$ \\
\hline Uncaria guianensis & --- & INPA & 106761 & Brasil & Amazonas & Novo Japurá & $01054^{\prime} 00 " \mathrm{~S}$ & $67000^{\prime} 00^{\prime \prime}$ & -.- & Amaral I. & 378 & $11 / 9 / 82$ \\
\hline Uncaria guianensis & --- & MG & 6865 & Brasil & Amazonas & Tabatinga & $03042^{\prime} 00^{\prime S} \mathrm{~S}$ & $69049^{\prime} 00^{\prime \prime}$ & & 00 Ducke A. & sn & 10/15/04 \\
\hline Uncaria guianensis & Espera-aí & INPA & 208280 & Brasil & Amazonas & Uarini Horizonte & $02039^{\circ} 00^{\prime \prime S}$ & $65020^{\prime} 00^{\prime \prime}$ & --. & Rocha S. et & 45 & $00 / 00 / 2000$ \\
\hline Uncaria guianensis & --- & INPA & 208215 & Brasil & Amazonas & Uarini Horizonte & $02039^{\circ} 00^{\prime \prime S}$ & $65020^{\prime} 00^{\prime \prime}$ & -- & Scarda F. & 17 & $1 / 23 / 01$ \\
\hline Uncaria guianensis & -.- & INPA & 116358 & Brasil & Maranhão & -.. & $04000^{\prime} 00^{\prime \prime S}$ & $44056^{\prime} 0^{\prime \prime}$ & -.- & Daly C. & 280 & $9 / 26 / 80$ \\
\hline Uncaria guianensis & -.- & MG & 686 & Brasil & Maranhão & -.- & -.. & -.- & -.- & Ducke A. & sn & 6/23/07 \\
\hline Uncaria guianensis &.-- & $\mathrm{RB}$ & 15692 & Brasil & Maranhão & Barra da Corda & $05053^{\prime} 00 " \mathrm{~s}$ & $45022^{\prime} 00^{\prime \prime}$ & & M. ${ }^{a}$ Lisbõa & sn & $7 / 20 / 09$ \\
\hline Uncaria guianensis & ... & $\mathrm{RB}$ & 15690 & Brasil & Maranhão & Barra da Corda & $05053^{\prime} 00 " \mathrm{~S}$ & $45022^{\prime} 00^{\prime \prime}$ & & "Ducke & sn & 6/23/07 \\
\hline Uncaria guianensis & -.- & MG & 15005 & Brasil & Maranhão & Balsas & 07o11'00"S & $45045^{\prime} 00^{\prime \prime}$ & -.- & Orlandi $\mathrm{R}$. & 627 & $3 / 31 / 84$ \\
\hline Uncaria guianensis &.-- & MG & 2464 & 4 Brasil & Maranhão & Barra da Corda & $05053^{\prime} 00^{\prime \prime S}$ & $45022^{\prime} 00^{\prime \prime}$ & -.- & Lisbôa R. & sn & $7 / 20 / 09$ \\
\hline Uncaria guianensis &.-- & $\mathrm{R}$ & 5430 & Brasil & Maranhão & Borra de Corda & $05053^{\prime} 00 " \mathrm{~s}$ & $45022^{\prime} 00^{\prime \prime}$ & & M. ${ }^{2}$ Lisbôa & & $7 / 20 / 09$ \\
\hline Uncaria guianensis & Paruá-cipó & MG & 76013 & Brasil & Maranhão & Carutapera & -.- &.-- & --- & Balée W. & 22 & $11 / 6 / 81$ \\
\hline Uncaria guianensis & Maracuçumé & HEO & 103311 & Brasil & Maranhão & Maracuçumé & ..- & -.. & -.- & Froes $\mathrm{R}$. & 34492 & $7 / 15 / 58$ \\
\hline Uncaria guianensis & --- & MG & 74072 & Brasil & Maranhão & Mineirinho & $03040^{\circ} 00^{\prime \prime S}$ & $45050^{\prime} 00^{\prime \prime}$ & & 50 Jangoux J. & 857 & $5 / 25 / 79$ \\
\hline Uncaria guianensis & -.- & HEO & 83914 & + Brasil & Maranhão & Perizes & ..- & -.. & -.- & Ablack G. & 54 & $7 / 6 / 54$ \\
\hline Uncaria guianensis & $\ldots$ & $\mathrm{RB}$ & 242249 & Brasil & Maranhão & Pinheiro & $02049^{\prime} 00^{\prime} \mathrm{S}$ & $45018^{\prime} 00^{\prime \prime}$ & & S. J. Filho & 191 & $8 / 7 / 84$ \\
\hline
\end{tabular}




\begin{tabular}{|c|c|c|c|c|c|c|c|c|c|c|c|c|}
\hline $\begin{array}{l}\text { Espécie } \\
\text { N.científico }\end{array}$ & N. vulgar & $\begin{array}{l}\text { Herbário } \\
\text { Siggla }\end{array}$ & Registro & $\begin{array}{l}\text { Localidade } \\
\text { País }\end{array}$ & Estado & Município & $\begin{array}{l}\text { Latitude } \\
\quad\left({ }^{\circ} \mathrm{S}, \mathrm{S}\right)\end{array}$ & $\begin{array}{c}\text { Longitude } \\
\left({ }^{\circ}, \mathrm{W}\right)\end{array}$ & $\begin{array}{l}\text { Altitude } \\
\text { (manm) }\end{array}$ & $\begin{array}{l}\text { COLETOR } \\
\text { Nome/número } \\
\end{array}$ & \multicolumn{2}{|c|}{ Data } \\
\hline Uncaria guianensis & --- & INPA & 182414 & 4 Brasil & Maranhão & Pinheiro & 02049'00"S & $45018^{\prime} 00^{\prime \prime}$ & --- & Jordy S. & 191 & $8 / 7 / 84$ \\
\hline Uncaria guianensis & $\ldots$ & MG & 61255 & Brasil & Maranhão & Santa Elena & ... & ... & ..- & Rosa $\mathrm{N}$. & 2544 & 7/9/78 \\
\hline Uncaria guianensis & -.- & MG & 146375 & Brasil & Maranhão & Santa Inês & $02009^{\prime} 00 " \mathrm{~S}$ & $45015^{\prime} 00^{\prime \prime}$ & -.. & Miranda C. & 478 & $7 / 27 / 84$ \\
\hline Uncaria guianensis & -.- & $\mathrm{RB}$ & 320679 & Brasil & Maranhão & & $03040^{\prime} 00^{\prime \prime S}$ & $45050^{\prime} 00^{\prime \prime}$ & & 100 J. Jangoux \& R.P. Bahia & 857 & $5 / 25 / 79$ \\
\hline Uncaria guianensis & --- & INPA & 185144 & 4 Brasil & Mato Grosso & (Margem do rio Mandico) & -.- & -.- & --- & Macedo $\mathrm{M}$. & 4168 & $5 / 30 / 85$ \\
\hline Uncaria guianensis & $\ldots$ & INPA & 176855 & Brasil & Mato Grosso & (Rio Jatoba) & ... & ... & .-. & Macedo M. & 2573 & $7 / 14 / 90$ \\
\hline Uncaria guianensis & Jupindá & MG & 153203 & Brasil & Mato Grosso & (Xingú) & -.- & -.- & -- & Athayde $S$. & 356 & $8 / 3 / 97$ \\
\hline Uncaria guianensis & -.- & INPA & 41979 & Brasil & Mato Grosso & Andurina & $10012^{\prime} 00 " \mathrm{~S}$ & $59021^{\prime} 00^{\prime \prime}$ & -.- & Berg C. & 18675 & $10 / 19 / 73$ \\
\hline Uncaria guianensis & --- & MG & 67802 & Brasil & Mato Grosso & Aripuanã & -.- & $\ldots$ & -.- & Silva M.G. & 4803 & $6 / 6 / 79$ \\
\hline Uncaria guianensis & ..- & $\mathrm{RB}$ & 113505 & Brasil & Mato Grosso & Barra das Garças & $15000^{\circ} 01 " \mathrm{~S}$ & $52021^{\prime} 06^{\prime \prime}$ & & a Lima & $58-3135$ & $5 / 6 / 58$ \\
\hline Uncaria guianensis & -.- & $\mathrm{RB}$ & 80047 & Brasil & Mato Grosso & Barra das Garças & $14042^{\prime} 00^{\prime \prime S}$ & $52021^{\prime} 00^{\prime \prime}$ & & 450 a Lima & $58-3135$ & $5 / 6 / 58$ \\
\hline Uncaria guianensis & -.- & ESA & sn & Brasil & Mato Grosso & Barra do Garças & $12051^{\prime} 00{ }^{\prime S} \mathrm{~S}$ & $51045^{\prime} 00^{\prime \prime}$ & & 450 Árbocz G.F. et & 3459 & 20/03/1997 \\
\hline Uncaria guianensis & --- & UEC & 123145 & Brasil & Mato Grosso & Baúcha do Norte & $13016^{\prime} 00 " \mathrm{~S}$ & $53023^{\prime} 00^{\prime \prime}$ & & N.M. Ivanauskas & 4321 & $6 / 8 / 00$ \\
\hline Uncaria guianensis & Unha de onça & $\mathrm{SP}$ & 11423 & Brasil & Mato Grosso & Boca do Marcelino & & & & F.C. Hoehne & & $00 / 06 / 1911$ \\
\hline Uncaria guianensis & $\ldots$ & ESA & 47290 & Brasil & Mato Grosso & Chapada dos Guimarães & 15031 '57"S & $55043^{\prime} 72^{\prime \prime}$ & & Nave AG. Et al & 1124 & $21 / 02 / 1997$ \\
\hline Uncaria guianensis & --- & ESA & 49644 & 4 Brasil & Mato Grosso & Cláudia & $11033^{\prime} 30^{\prime \prime S}$ & $55013^{\prime} 36^{\prime \prime}$ & & Nave AG. Et al & 1569 & 13/07/1997 \\
\hline Uncaria guianensis & & ESA & sn & Brasil & Mato Grosso & Cocalinho & & & & Rozza a et al. & 414 & $00 / 00 / 1997$ \\
\hline Uncaria guianensis & $\ldots$ & $\mathrm{RB}$ & 110699 & Brasil & Mato Grosso & Guajará Mirim & & & & J. G. Kuhlmann & 438 & 9/12/23 \\
\hline Uncaria guianensis & $\ldots$ & UEC & 96842 & Brasil & Mato Grosso & Juruena & & & & A C. L.H. Barbosa & $\mathrm{sn}$ & $00 / 05 / 1998$ \\
\hline Uncaria guianensis & --- & ESA & 47287 & Brasil & Mato Grosso & Marcelândia & $10027^{\prime} 00 " \mathrm{~S}$ & $54010^{\prime} 00^{\prime \prime}$ & & Souza V.C. et al. & 15517 & $24 / 04 / 1997$ \\
\hline Uncaria guianensis & Unha de onça & $\mathrm{SP}$ & 11422 & Brasil & Mato Grosso & Melgaço & & & & F.C. Hoehne & $\mathrm{sn}$ & sd \\
\hline Uncaria guianensis & Unha de onça & $\mathrm{R}$ & 14411 & Brasil & Mato Grosso & Melgaço & & & & F.C. Hoehne & 4891 & $00 / 02 / 1911$ \\
\hline Uncaria guianensis & Unha de onça & $\mathrm{R}$ & 14412 & Brasil & Mato Grosso & Melgaço & & & & F.C. Hoehne & 4735 & $00 / 02 / 1911$ \\
\hline Uncaria guianensis & -.- & ESA & 47293 & Brasil & Mato Grosso & Nova Bandeirantes & $09049^{\prime 2} 23 " \mathrm{~S}$ & $57049^{\prime} 36^{\prime \prime}$ & & Árbocz G.F. et & 3884 & $30 / 05 / 1997$ \\
\hline Uncaria guianensis & $\ldots$ & INPA & 58388 & B Brasil & Mato Grosso & Poconé & -.- & -.- & -.- & Macedo M. & 119 & $7 / 16 / 76$ \\
\hline Uncaria guianensis & -.. & SPF & 45415 & Brasil & Mato Grosso & Porto dos Gaúchos & $11040^{\circ} 00^{\prime \prime S}$ & $56017^{\prime} 00^{\prime \prime}$ & & W. Thomas et al, & $\mathrm{sn}$ & $10 / 23 / 85$ \\
\hline Uncaria guianensis & -.- & INPA & 150501 & Brasil & Mato Grosso & Porto dos Gaúchos & $11040^{\circ} 00^{\prime S} \mathrm{~S}$ & $56017^{\prime} 00^{\prime \prime}$ & --. & Thomas $\mathrm{w}$. & 3997 & $9 / 23 / 85$ \\
\hline Uncaria guianensis & -.- & ESA & 47288 & Brasil & Mato Grosso & São José do Rio Claro & $13018^{\prime} 43 " \mathrm{~S}$ & $56043^{\prime} 40^{\prime \prime}$ & & Rozza a et al. & 339 & $26 / 04 / 1997$ \\
\hline Uncaria guianensis & --- & ESA & 47294 & Brasil & Mato Grosso & Vila Rica & & & & Bernacci L.C. & 2247 & 6/8/97 \\
\hline Uncaria guianensis & -.. & ESA & 47289 & Brasil & Mato Grosso & Xavantina & $14050^{\circ} 477^{\prime S}$ & $52008^{\prime} 37 "$ & & Ivanauskas N.M. & 1325 & $21 / 03 / 1997$ \\
\hline Uncaria guianensis & -.- & HEO & 136032 & Brasil & Mato Grosso & Xavantina & $12054^{\prime} 00^{\prime \prime S}$ & $51052^{\prime} 00^{\prime \prime}$ & --. & de Santos R. & 1463 & $5 / 18 / 68$ \\
\hline Uncaria guianensis & -.- & MG & 2916 & Brasil & Mato Grosso & Yurinam & -.- & -.. & --. & Ducke A. & 718 & $8 / 7 / 02$ \\
\hline Uncaria guianensis & --- & $\mathrm{RB}$ & 146178 & Brasil & Mato Grosso & & $12049^{\prime} 00^{\prime \prime S}$ & $51046^{\prime} 00^{\prime \prime}$ & & D. Philcox \& a Ferreira & 4225 & $1 / 30 / 68$ \\
\hline Uncaria guianensis & -.- & $\mathrm{R}$ & 27212 & 2 Brasil & Mato Grosso & & & & & C. ${ }^{a}$ M. Lindeman & $\mathrm{sn}$ & $00 / 00 / 0000$ \\
\hline Uncaria guianensis & -.- & $\mathrm{R}$ & 14413 & Brasil & Mato Grosso & & & & & F.C. Hoehne & 2790 & $00 / 06 / 1911$ \\
\hline Uncaria guianensis & -.- & $\mathrm{R}$ & 14414 & 4 Brasil & Mato Grosso & & & & & F.C. Hoehne & 2789 & $00 / 06 / 1911$ \\
\hline Uncaria guianensis & ... & $\mathrm{R}$ & 14415 & Brasil & Mato Grosso & & & & & F.C. Hoehne & 2788 & $00 / 06 / 1911$ \\
\hline Uncaria guianensis & -.. & HEO & 132434 & 4 Brasil & Pará & -.. & -.. & -.. & -.- & Ribeiro B. & $1 \mathrm{a}$ & $10 / 19 / 69$ \\
\hline Uncaria guianensis & --- & $\mathrm{R}$ & 180245 & Brasil & Pará & (Bacia rio Trombetas, $1 \mathrm{~km}$ & $\mathrm{n}$ sul de cacho & Porteira) & & D.G.Campbell et al. & $\mathrm{p} 22453$ & 6/2/74 \\
\hline Uncaria guianensis & $\ldots$ & HEO & 81985 & Brasil & Pará & (Rio Guamá) & $\ldots$ & $\ldots$ & $\ldots$ & Pires J. & 4619 & $00 / 06 / 1953$ \\
\hline
\end{tabular}




\begin{tabular}{|c|c|c|c|c|c|c|c|c|c|c|c|c|}
\hline $\begin{array}{l}\text { Espécie } \\
\text { N.científico }\end{array}$ & N. vulgar & $\begin{array}{l}\text { Herbário } \\
\text { Sigla }\end{array}$ & Registro & $\begin{array}{l}\text { Localidade } \\
\text { País }\end{array}$ & Estado & Município & $\begin{array}{l}\text { Latitude } \\
\quad\left({ }^{\circ}, S, S\right)\end{array}$ & $\begin{array}{c}\text { Longitude } \\
\left({ }^{\circ}, \mathrm{W}\right)\end{array}$ & $\begin{array}{l}\text { Altitude } \\
\text { (manm) }\end{array}$ & $\begin{array}{l}\text { COLETOR } \\
\text { Nome/número }\end{array}$ & & \\
\hline Uncaria guianensis & --- & HEO & 103442 & Brasil & Pará & (Rio Piríá) & --- & --- & --- & Froes $\mathrm{R}$. & 34623 & $8 / 18 / 58$ \\
\hline Uncaria guianensis & Unha-de-gato & MG & 144549 & Brasil & Pará & Afuá & $\ldots$ & $\cdots$ & -- & Maciel & 1991 & 9/12/92 \\
\hline Uncaria guianensis & -.- & INPA & 149056 & 5 Brasil & Pará & Almeirim & -.- & --. & -.. & Pires M. et & 885 & $4 / 18 / 86$ \\
\hline Uncaria guianensis & -.- & MG & 123398 & Brasil & Pará & Almerim & $\ldots$ & ... & ... & Pires $\mathrm{M}$. & sn & $4 / 18 / 86$ \\
\hline Uncaria guianensis & Junpidá-do-vermelho & MG & 111274 & 4 Brasil & Pará & Barcarena & $01025^{\prime} 00 " \mathrm{~S}$ & $48027^{\prime} 00^{\prime \prime}$ & --- & Anderson A. & 1463 & $00 / 12 / 1984$ \\
\hline Uncaria guianensis & $\ldots$ & MG & 111230 & Brasil & Pará & Barcarena & $01025^{\prime} 00 " \mathrm{~S}$ & $48027^{\circ} 00^{\prime \prime}$ & .-. & $\mathrm{s} / \mathrm{c}$ & sn & $00 / 12 / 1984$ \\
\hline Uncaria guianensis &.-- & $\mathrm{R}$ & 5464 & 4 Brasil & Pará & Belém & & & & "Goeldi & 2836 & $7 / 30 / 02$ \\
\hline Uncaria guianensis & -.- & $\mathrm{RB}$ & 15689 & Brasil & Pará & Belém & & & & " Goeldi & sn & $7 / 30 / 02$ \\
\hline Uncaria guianensis & --- & HEO & 71158 & Brasil & Pará & Belém & -.- & -.- & -.- & Pires J. & 3456 & $10 / 3 / 51$ \\
\hline Uncaria guianensis & ..- & HEO & 32153 & Brasil & Pará & Belém & ... & ... & .-. & Black G. & sn & $00 / 02 / 1948$ \\
\hline Uncaria guianensis & -.- & MG & 2836 & 6 Brasil & Pará & Belém & -.. & -.. & -.- & Goeldi A. & $\mathrm{sn}$ & $7 / 30 / 02$ \\
\hline Uncaria guianensis & -.- & HEO & 30102 & Brasil & Pará & Belterra & -.. & -.. & -.- & Black G. & 47-1902 & $10 / 31 / 47$ \\
\hline Uncaria guianensis & Cuerussu & MG & 10612 & Brasil & Pará & Campo do Macuarany & -.- & -.- & -.- & Ducke A. & sn & $1 / 31 / 10$ \\
\hline Uncaria guianensis & $\ldots$ & HEO & 123812 & Brasil & Pará & Capitão Poço & ... & ... & ..- & Silva M. & 682 & $8 / 10 / 66$ \\
\hline Uncaria guianensis & -.- & HEO & 155616 & Brasil & Pará & Chaves & -.. & -.. & --- & Rosa N. & 2444 & $6 / 21 / 78$ \\
\hline Uncaria guianensis & --- & MG & 80210 & Brasil & Pará & Conceição do Araguaia & $08013^{\prime} 00 " \mathrm{~S}$ & $49036^{\prime} 00^{\prime \prime}$ & & 00 Plowman T. & 9035 & $2 / 23 / 80$ \\
\hline Uncaria guianensis & --- & INPA & 12359 & Brasil & Pará & Cuminá-Mirim & -.- & -.- & -.- & Egler $W$. & 202 & $5 / 24 / 57$ \\
\hline Uncaria guianensis & $\ldots$ & INPA & 164024 & 4 Brasil & Pará & ilha Marajó & $\ldots$ & ... & -.- & Rabelo B. & 3774 & $11 / 9 / 87$ \\
\hline Uncaria guianensis & $\ldots$ & INPA & 112544 & 4 Brasil & Pará & Itaituba & $08045^{\circ} 00^{\prime \prime S}$ & $54057^{\circ} 00^{\prime \prime}$ & .-. & Amaral I. & 1153 & $5 / 4 / 83$ \\
\hline Uncaria guianensis & -.- & INPA & 113425 & Brasil & Pará & Itaituba & $07025^{\prime} 00^{\prime \prime S}$ & $55020^{\prime} 00^{\prime \prime}$ & .-. & Silva M. & 303 & $5 / 12 / 83$ \\
\hline Uncaria guianensis & --- & MG & 94589 & Brasil & Pará & Macau & $00055^{\circ} 00 " \mathrm{~S}$ & $54026^{\prime} 00^{\prime \prime}$ & & 60 Strudwick J. & 3500 & $7 / 24 / 81$ \\
\hline Uncaria guianensis & $\ldots$ & MG & 105872 & Brasil & Pará & Marabapá & $06006^{\prime} 00^{\prime \prime S}$ & $50017^{\prime} 00^{\prime \prime}$ & & 75 Sperling C. & sn & $5 / 28 / 82$ \\
\hline Uncaria guianensis & $\ldots$ & $\mathrm{MG}$ & 61155 & Brasil & Pará & Marajó & $\ldots$ & ... & .-. & Rosa N. & 2444 & $6 / 21 / 78$ \\
\hline Uncaria guianensis & Unha de gato & HEO & 113041 & Brasil & Pará & Muana & -.- & -.. & --. & Oliveira E. & 2099 & $6 / 30 / 62$ \\
\hline Uncaria guianensis & -.- & INPA & 154736 & Brasil & Pará & Oriximiná & $01003^{\prime} 00 " \mathrm{~S}$ & $57003^{\prime} 00^{\prime \prime}$ & -.- & Knowles O. & 1051 & $6 / 19 / 87$ \\
\hline Uncaria guianensis & -.. & INPA & 96433 & Brasil & Pará & Oriximiná & $01000^{\circ} 00^{\prime \prime S}$ & $57000^{\prime} 00^{\prime \prime}$ & --- & Cid C. & 2194 & $9 / 6 / 80$ \\
\hline Uncaria guianensis & -.- & INPA & 46413 & Brasil & Pará & Oriximiná & $01003^{\prime} 00 " \mathrm{~S}$ & $57003^{\prime} 00^{\prime \prime}$ & --. & Campbell D. & 22453 & 6/2/74 \\
\hline Uncaria guianensis & -.- & INPA & 173110 & Brasil & Pará & Oriximiná & $01000^{\prime} 00^{\prime S} \mathrm{~S}$ & $57000^{\prime} 00^{\prime \prime}$ & --. & Suares E. & 770 & $00 / 00 / 1990$ \\
\hline Uncaria guianensis & --- & INPA & 176093 & Brasil & Pará & Oriximiná & $01003^{\prime} 00 " \mathrm{~S}$ & $57003^{\prime} 00^{\prime \prime}$ & --- & Suares E. & 315 & $00 / 00 / 1991$ \\
\hline Uncaria guianensis & -.. & INPA & 117696 & Brasil & Pará & Oriximiná & $01000^{\circ} 00^{\prime \prime S}$ & $57000^{\prime} 00^{\prime \prime}$ & --- & Davidson C. & 10655 & $6 / 3 / 80$ \\
\hline Uncaria guianensis & -.- & MG & 77636 & Brasil & Pará & Oriximiná & $01000^{\prime} 00 " \mathrm{~S}$ & $57000^{\prime} 00^{\prime \prime}$ & --. & Cid C. & 2194 & 9/6/80 \\
\hline Uncaria guianensis & -.- & MG & 98318 & Brasil & Pará & Oriximiná & $01003^{\prime} 00 " \mathrm{~S}$ & $57003^{\prime} 00^{\prime \prime}$ & --. & Davidson C. & 10655 & $31 / 06 / 1980$ \\
\hline Uncaria guianensis & Pau-d'arco & INPA & 207754 & 4 Brasil & Pará & Pão D'Arco & ... & ... & $\ldots$ & Grogan J. & 400 & $5 / 12 / 97$ \\
\hline Uncaria guianensis & $\ldots$ & MG & 37035 & Brasil & Pará & Santarém & ..- & -.- & -.- & Silva M. & 2219 & $8 / 12 / 69$ \\
\hline Uncaria guianensis & -.- & MG & 142979 & Brasil & Pará & São Sebastião de Boa Vist & $\ldots$ & ... & -.- & Santos C. & 32 & 9/2/92 \\
\hline Uncaria guianensis & -.- & INPA & 104147 & Brasil & Rondônia & Ariquemes & $10035^{\prime} 00 " \mathrm{~S}$ & $63035^{\prime} 00^{\prime \prime}$ & -.- & eixeira L. & 410 & $5 / 13 / 82$ \\
\hline Uncaria guianensis & --- & MG & 96927 & Brasil & Rondônia & Ariquemes & $10035^{\prime} 00 " \mathrm{~S}$ & $63035^{\prime} 00^{\prime \prime}$ & --- & Texeira L. & 410 & $5 / 13 / 82$ \\
\hline Uncaria guianensis & -.. & HEO & 118309 & Brasil & Rondônia & Guajará-Mirim & -.. & -.. & -.- & Pires Z. & 10028 & $7 / 6 / 65$ \\
\hline Uncaria guianensis & --- & INPA & 21944 & 4 Brasil & Rondônia & Ji-Paraná & -.- & -.- & --- & Prince G. & 5184 & $6 / 25 / 68$ \\
\hline Uncaria guianensis & $\ldots$ & INPA & 22335 & Brasil & Rondônia & Matumparaná & $\ldots$ & $\ldots$ & $\ldots$ & Prince G. & 5575 & $7 / 4 / 68$ \\
\hline
\end{tabular}




\begin{tabular}{|c|c|c|c|c|c|c|c|c|c|c|c|c|}
\hline $\begin{array}{l}\text { Espécie } \\
\text { N.científico }\end{array}$ & N. vulgar & $\begin{array}{l}\text { Herbário } \\
\text { Siggla }\end{array}$ & Registro & $\begin{array}{l}\text { Localidade } \\
\text { País }\end{array}$ & Estado & Município & $\begin{array}{l}\text { Latitude } \\
\quad\left({ }^{\circ}, S, S\right)\end{array}$ & $\begin{array}{c}\text { Longitude } \\
\left({ }^{\circ}, \mathrm{W}\right)\end{array}$ & $\begin{array}{r}\text { Altitude } \\
(\text { manm })\end{array}$ & $\begin{array}{l}\text { COLETOR } \\
\text { Nome/número } \\
\end{array}$ & & \\
\hline Uncaria guianensis & --- & $\mathrm{MG}$ & 156519 & Brasil & Rondônia & Pimenta Bueno & $12045^{\prime} 00^{\prime \prime S}$ & $60010^{\prime} 00^{\prime \prime}$ & --- & Miranda I. & 1911 & $6 / 22 / 98$ \\
\hline Uncaria guianensis & $\ldots$ & $\mathrm{R}$ & 123147 & Brasil & Rondonia & Porto Velho & $09000^{\prime} 00^{\prime \prime S}$ & $62044^{\prime} 05^{\prime \prime}$ & & 115 G.T.Prance et al. & 5184 & $6 / 25 / 68$ \\
\hline Uncaria guianensis & -.- & MG & 84683 & Brasil & Rondônia & Porto Velho & $09000^{\prime} 00 " \mathrm{~S}$ & $62044^{\prime} 05^{\prime \prime}$ & & 115 Silva M. & 5869 & $5 / 28 / 82$ \\
\hline Uncaria guianensis & -.- & MG & 86827 & Brasil & Rondônia & Porto Velho & $09000^{\prime} 00^{\prime S} \mathrm{~S}$ & $62044^{\prime} 05^{\prime \prime}$ & & 115 Goulding $\mathrm{M}$. & 1329 & $00 / 01 / 1981$ \\
\hline Uncaria guianensis & --- & MG & 58168 & Brasil & Rondônia & Porto Velho & $09000^{\prime} 00^{\prime \prime S}$ & 62044'05" & & 115 Santos J. & 272 & $3 / 27 / 78$ \\
\hline Uncaria guianensis & $\ldots$ & MG & 38445 & Brasil & Rondônia & Porto Velho & $09000^{\prime} 00^{\prime \prime S}$ & $62044^{\prime} 05^{\prime \prime}$ & & 115 Prance G. & 5855 & $7 / 11 / 68$ \\
\hline Uncaria guianensis &.-- & INPA & 153604 & Brasil & Rondônia & Porto Velho & $09000^{\prime} 00^{\prime \prime S}$ & $62044^{\prime} 05^{\prime \prime}$ & & 115 Cid C. & 8950 & $4 / 29 / 87$ \\
\hline Uncaria guianensis & -.- & HEO & 152365 & Brasil & Rondônia & Porto Velho & $09000^{\prime} 00^{\prime S} \mathrm{~S}$ & $62044^{\prime} 05^{\prime \prime}$ & & 115 Nascimento $O$. & 319 & $5 / 4 / 76$ \\
\hline Uncaria guianensis & --- & MG & 38638 & Brasil & Rondônia & Porto Velho & $09000^{\circ} 00^{\prime \prime S}$ & $62044^{\prime} 05^{\prime \prime}$ & & 115 Prance G. & 6439 & $7 / 25 / 68$ \\
\hline Uncaria guianensis & ..- & MG & 119751 & Brasil & Rondônia & Presidente Medici & $11012^{\prime} 00 " \mathrm{~S}$ & $62063^{\prime} 00^{\prime \prime}$ & .-. & Cid C. & 4856 & $6 / 28 / 84$ \\
\hline Uncaria guianensis & -.- & INPA & 141613 & Brasil & Roraima & Alto Alegre & $03024^{\prime} 00^{\prime \prime} \mathrm{N}$ & $61026^{\circ} 00^{\prime \prime}$ & -.- & Barbosa M. & 911 & $10 / 1 / 86$ \\
\hline Uncaria guianensis & Unha-lontra & INPA & 141634 & Brasil & Roraima & Alto Alegre & $03024^{\prime} 00^{\prime \prime} \mathrm{N}$ & $61026^{\prime} 0^{\prime \prime}$ & -.- & Barbosa M. & 937 & $10 / 2 / 86$ \\
\hline Uncaria guianensis & -.- & INPA & 152210 & Brasil & Roraima & Alto Alegre & $03024^{\prime} 00^{\prime \prime} \mathrm{N}$ & $61026^{\prime} 00^{\prime \prime}$ & $\ldots$ & Hopkins M. & 589 & $6 / 8 / 86$ \\
\hline Uncaria guianensis & $\ldots$ & HEO & 156367 & Brasil & Roraima & Boa Vista & $02050^{\circ} 00^{\prime \prime} \mathrm{N}$ & $60040^{\circ} 00^{\prime \prime}$ & & 520 Coradin $\mathrm{L}$. & 898 & $10 / 26 / 77$ \\
\hline Uncaria guianensis & -.- & MG & 55681 & Brasil & Roraima & Boa Vista & $02050^{\prime} 00^{\prime \prime} \mathrm{N}$ & $60040^{\prime} 00^{\prime \prime}$ & --- & Santos $\mathrm{M}$. & 161 & $3 / 4 / 77$ \\
\hline Uncaria guianensis & --- & INPA & 155238 & Brasil & Roraima & Illha Maracá & $03020^{\prime} 00^{\prime \prime} \mathrm{N}$ & $61025^{\prime} 00^{\prime \prime}$ & --- & Pruski J. & 3453 & 10/9/87 \\
\hline Uncaria guianensis & --- & INPA & 167749 & Brasil & Roraima & Illha Maracá & $03022^{\prime} 00 " \mathrm{~N}$ & $61025^{\prime} 00^{\prime \prime}$ & --. & Ratter J. & 5841 & $3 / 24 / 87$ \\
\hline Uncaria guianensis & & NY & ***** & Brasil & Tocantins & Formoso de Araguaia & $\ldots$ & & & 250 P. Delprete et al. 6531 & & $8 / 14 / 98$ \\
\hline Uncaria guianensis & & NY & $* * * *$ & Brasil & Tocantins & Tocantinópolis & ... & & .-. & P. Delprete et al. 6576 & & $8 / 23 / 98$ \\
\hline Uncaria guianensis & & мо & $* * * *$ & Colômbia & Amazonas & -.- & 00037'00"S & $7200700 "$ & & 200 A.vanDulmen 248 & & $8 / 11 / 94$ \\
\hline Uncaria guianensis & & мо & $* * * *$ & Colômbia & Amazonas & Amacayacu & $03003^{\prime} 00 " \mathrm{~S}$ & $70003^{\prime} 00^{\prime \prime}$ & & 100 A.Rudas et al. 2134 & & 6/19/91 \\
\hline Uncaria guianensis & & мо & ***** & Colômbia & Amazonas & Amacayacu & $03047^{\circ} 00^{\prime \prime S}$ & $70015^{\prime} 00^{\prime \prime}$ & & 100 A.Rudas et al. 1538 & & $3 / 11 / 91$ \\
\hline Uncaria guianensis & & мо & $* * * *$ & Colômbia & Amazonas & Amacayacu & $03009^{\prime} 00^{\prime \prime S}$ & $70016^{\prime} 00^{\prime \prime}$ & & 100 A.Rudas et al. 2632 & & 6/29/91 \\
\hline Uncaria guianensis & & мо & **** & Colômbia & Amazonas & -.. & -.- & & & 125 D.Cardenas et al. 4592 & & 4/7/94 \\
\hline Uncaria guianensis & & мо & $* * * *$ & Colômbia & Antioquia & ... & $07021^{\prime} 00 " \mathrm{~N}$ & $75003^{\prime} 00^{\prime \prime}$ & & 330 J.L.Zarucchi 3374 & & $10 / 3 / 84$ \\
\hline Uncaria guianensis & & мо & ***** & Colômbia & Antioquia & ... & $08004^{\prime} 00^{\prime \prime} \mathrm{N}$ & $75005^{\prime} 00^{\prime \prime}$ & & 60 J.L.Zarucchi et al. 4263 & & $11 / 25 / 86$ \\
\hline Uncaria guianensis & & мо & $* * * *$ & Colômbia & Antioquia & $\ldots$ & $08004^{\prime} 00^{\prime \prime} \mathrm{N}$ & $75005^{\prime} 00^{\prime \prime}$ & & 100 R.Fonnegra et al. 7232 & & $11 / 6 / 00$ \\
\hline Uncaria guianensis & & мо & **** & Colômbia & Antioquia & -.. & -.- & & & 100 Fonnegra et al. 2540 & & $1 / 10 / 89$ \\
\hline Uncaria guianensis & & мо & $* * * *$ & Colômbia & Antioquia & -.- & -.- & & & 100 Fonnegra et al. 2541 & & $1 / 10 / 89$ \\
\hline Uncaria guianensis & & мо & $* * * *$ & Colômbia & Guaviare & -.. & $02053^{\prime} 31 " \mathrm{~N}$ & 72054'42" & & 220 R. López et al. 694 & & $11 / 15 / 95$ \\
\hline Uncaria guianensis & & мо & $* * * *$ & Equador & Napo & ... & $00025^{\prime} 00 " \mathrm{~s}$ & $77000^{\prime} 00^{\prime \prime}$ & & 250 D.Neill et al. 7297 & & 9/10/86 \\
\hline Uncaria guianensis & & мо & **** & Equador & Napo & -.. & $00020^{\prime} 00^{\prime \prime S}$ & $77005^{\prime} 00^{\prime \prime}$ & & 250 E.Gudiño 184 & & $11 / 12 / 89$ \\
\hline Uncaria guianensis & & мо & $* * * *$ & Equador & Napo & -.- & 00047'00"S & $77028^{\prime} 00^{\prime \prime}$ & & 560 H.Vargas 3621 & & 3/28/99 \\
\hline Uncaria guianensis & & мо & $* * * *$ & Equador & Napo & -.- & $01004^{\prime} 00 " \mathrm{~s}$ & $77036^{\circ} 00^{\prime \prime}$ & & 450 D.Neill et al. 8681 & & $1 / 5 / 89$ \\
\hline Uncaria guianensis & & мо & $* * * *$ & Equador & Napo & ... & $01004^{\prime} 00 " \mathrm{~s}$ & $77036^{\circ} 00^{\prime \prime}$ & & 450 W.Palacios 12853 & & $10 / 24 / 94$ \\
\hline Uncaria guianensis & & мо & $* * * *$ & Equador & Napo & -.- & $01004^{\prime} 00 " \mathrm{~S}$ & $77036^{\prime} 00^{\prime \prime}$ & & 450 J.Zuruma 262 & & $5 / 27 / 85$ \\
\hline Uncaria guianensis & & мо & $* * * *$ & Equador & Napo & ... & $00015 ' 57 " \mathrm{~S}$ & $77052^{\prime} 58^{\prime \prime}$ & & 300 Brandbyge et al. 33572 & & $8 / 16 / 81$ \\
\hline Uncaria guianensis & & мо & $* * * *$ & Equador & Napo & -.. & -.. & & -.- & A.Gentry et al. 21792 & & sd \\
\hline Uncaria guianensis & & мо & $* * * *$ & Equador & Napo & -.. & -.- & & --- & R. Burnham 1746 & & $10 / 18 / 98$ \\
\hline Uncaria guianensis & & мо & $* * *$ & Equador & Napo & Sumaco & $00008^{\prime} 00 " \mathrm{~S}$ & $77008^{\prime} 00^{\prime \prime}$ & & 400 H.Vargas et al. 1008 & & $9 / 30 / 96$ \\
\hline
\end{tabular}




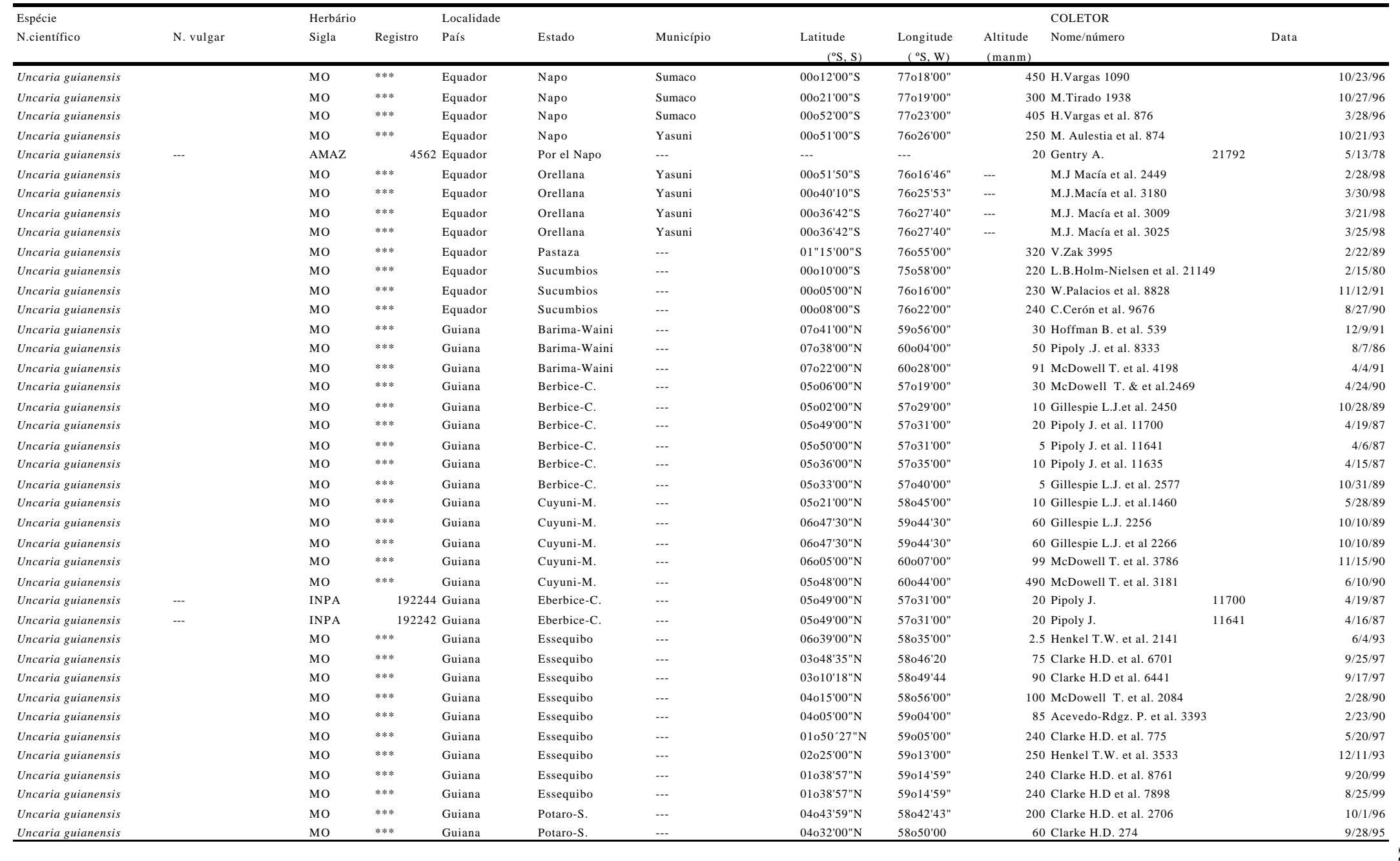




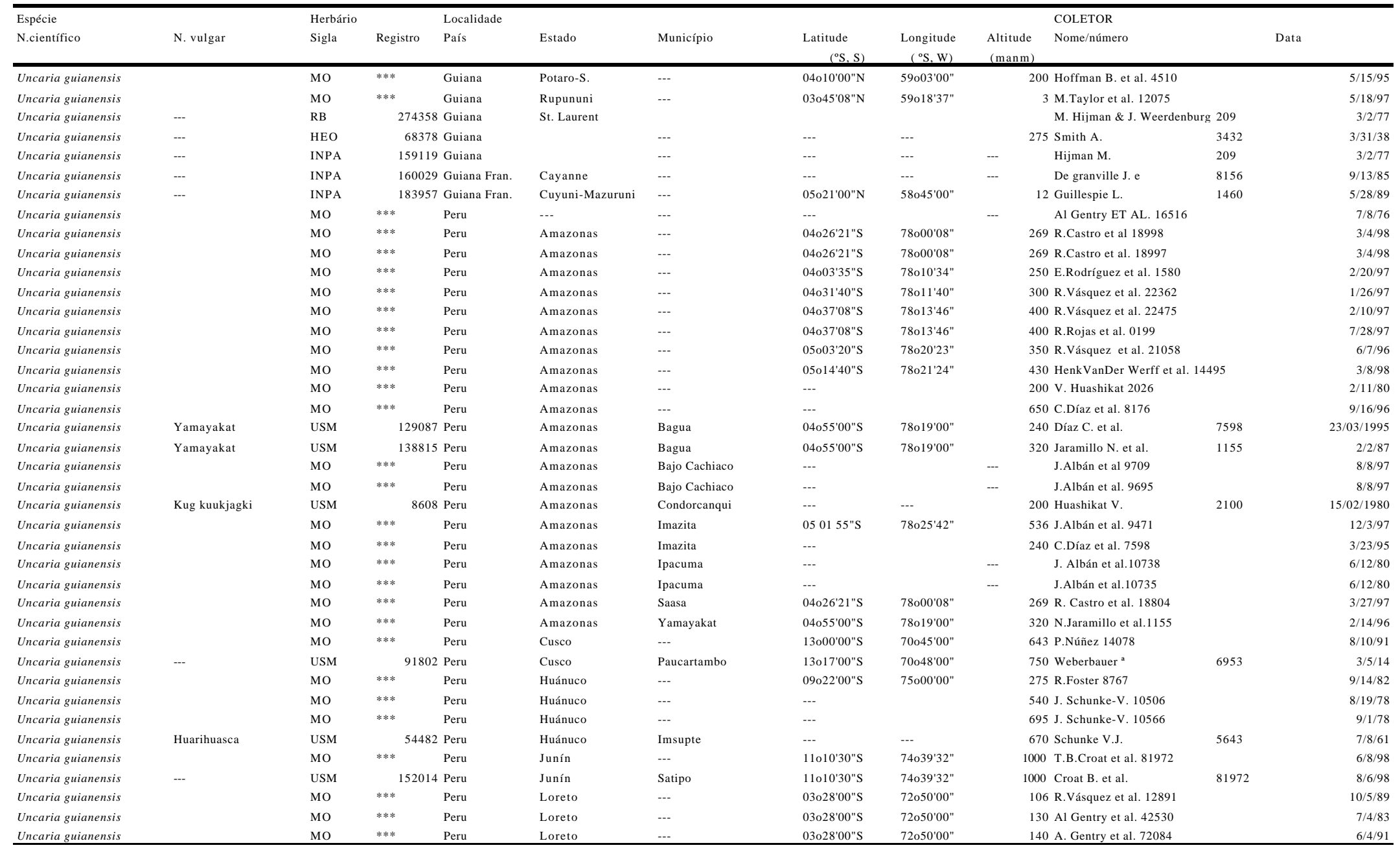




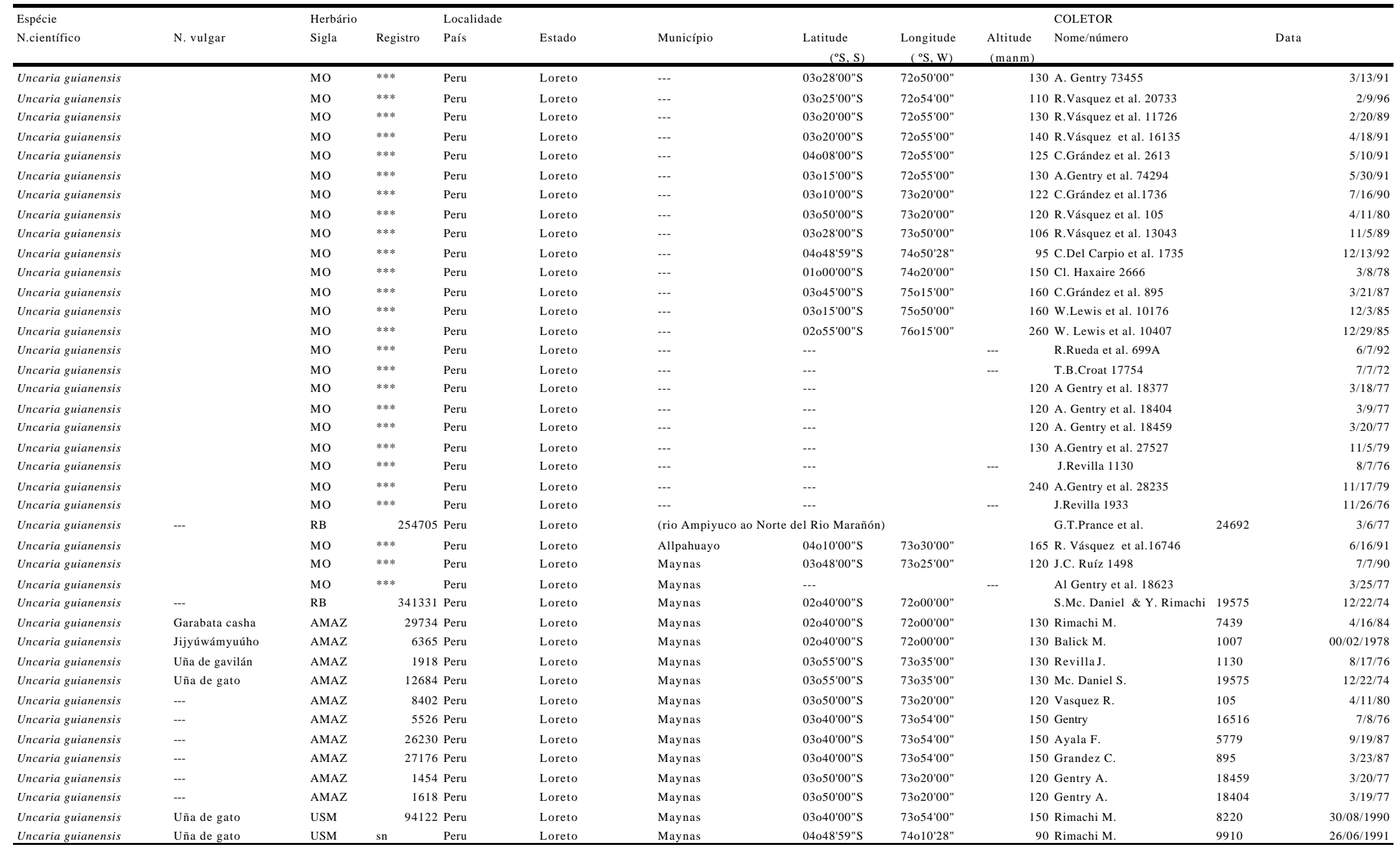




\begin{tabular}{|c|c|c|c|c|c|c|c|c|c|c|c|c|}
\hline \multirow{2}{*}{$\begin{array}{l}\text { Espécie } \\
\text { N.científico }\end{array}$} & \multirow[b]{2}{*}{ N. vulgar } & \multicolumn{2}{|l|}{ Herbário } & \multicolumn{3}{|l|}{ Localidade } & \multirow[b]{2}{*}{$\begin{array}{l}\text { Latitude } \\
\quad\left({ }^{\circ} \mathrm{S}, \mathrm{S}\right)\end{array}$} & \multicolumn{3}{|r|}{ COLETOR } & \multirow{2}{*}{\multicolumn{2}{|c|}{ Data }} \\
\hline & & Sigla & Registro & País & Estado & Município & & $\begin{array}{l}\text { Longitude } \\
\text { os }\end{array}$ & Altitud & e Nome/número & & \\
\hline Uncaria guianensis & Tambo-huasca & USM & 91801 & Peru & Loreto & Maynas & 01010'00"s & $74044^{\prime} 00^{\prime \prime}$ & & 100 Mathias M.E. et al & 3881 & $19 / 07 / 1959$ \\
\hline Uncaria guianensis & Garabatocasha & USM & 91803 & Peru & Loreto & Maynas & $03046^{\prime} 00^{\prime \prime S}$ & $73025^{\prime} 00^{\prime \prime}$ & & 110 Schunke V.J. & 225 & $11 / 2 / 35$ \\
\hline Uncaria guianensis & --- & USM & 41358 & Peru & Loreto & Maynas & $030500^{\prime} 00 " \mathrm{~S}$ & $73020^{\prime} 00^{\prime \prime}$ & & 120 Gentry A. et al. & 18459 & 20/03/1977 \\
\hline Uncaria guianensis & Garabato casha & USM & sn & Peru & Loreto & Maynas & $03040^{\prime} 00^{\prime \prime S}$ & 73054'00" & & 160 Rimachi M. & 7439 & $16 / 04 / 1984$ \\
\hline Uncaria guianensis & --- & USM & 91805 & Peru & Loreto & Maynas & $03040 \prime 00 " \mathrm{~S}$ & 73054'00" & & 160 Gentry Al. et al & 18404 & 19/03/1977 \\
\hline Uncaria guianensis & --- & USM & 91800 & Peru & Loreto & Maynas & $03040^{\prime} 00^{\prime \prime} \mathrm{S}$ & 73054'00" & & 160 Gentry Al. et al & 18377 & $18 / 03 / 1977$ \\
\hline Uncaria guianensis & & MO & **** & Peru & Loreto & Mishina & 03055'00"S & 73035'00" & & $130 \mathrm{~J}$ J. Pipoly et al. 14868 & & $3 / 13 / 91$ \\
\hline Uncaria guianensis & --- & INPA & 91653 & Peru & Loreto & Nauta & 04048'59"S & $74010^{\prime} 28^{\prime \prime}$ & & 95 Prance G. & 24692 & $3 / 6 / 77$ \\
\hline Uncaria guianensis & Uña de gato & USM & 114367 & Peru & Loreto & Nauta & 04048'59"S & $74010^{\prime} 28 "$ & & 95 Carpi C. del et al. & 1735 & $13 / 11 / 1992$ \\
\hline Uncaria guianensis & -.- & USM & 50152 & Peru & Loreto & Nauta & 04048 '59"S & $74010^{\prime} 28 "$ & & 95 Prance G. et al. & 24692 & 6/3/77 \\
\hline Uncaria guianensis & & мо & $* * *$ & Peru & Loreto & Pacaya-Samiria & $03018^{\prime} 00 " \mathrm{~S}$ & $74050^{\circ} 00^{\prime \prime}$ & & 130 C.Grández et al. 1964 & & $10 / 19 / 90$ \\
\hline Uncaria guianensis & & мо & $* * *$ & Peru & Loreto & Ramón Castilla & -.. & & -.- & F.Ayala et al. 3243 & & $4 / 23 / 82$ \\
\hline Uncaria guianensis & --- & AMAZ & 11519 & Peru & Loreto & Ramón Castilla & -.- & -.. & & 110 Ayala F. & 3243 & $4 / 23 / 82$ \\
\hline Uncaria guianensis & & мо & $* * * *$ & Peru & Madre de Dios & -.- & $12003^{\prime 2} 23^{\prime S} \mathrm{~S}$ & $68044^{\prime} 13^{\prime \prime}$ & & 210 M.Aguilar et al. 686 & & $4 / 25 / 96$ \\
\hline Uncaria guianensis & & мо & $* * * *$ & Peru & Madre de Dios & -.. & $12029^{\prime} 00^{\prime \prime} \mathrm{S}$ & $69003^{\prime} 00^{\prime \prime}$ & & 200 M.Timaná et al. 2852 & & 10/28/91 \\
\hline Uncaria guianensis & & мо & ***** & Peru & Madre de Dios & $\cdots$ & $12035^{\circ} 00^{\prime S} \mathrm{~S}$ & $69004^{\prime} 00^{\prime \prime}$ & & 200 A.Gentry et al. 69397 & & $2 / 21 / 90$ \\
\hline Uncaria guianensis & & мо & **** & Peru & Madre de Dios & --- & $12032^{\prime} 00^{\prime \prime S}$ & $69015^{\prime} 00^{\prime \prime}$ & & 240 R.Vásquez et al. 12407 & & $7 / 20 / 89$ \\
\hline Uncaria guianensis & & мо & $* * * *$ & Peru & Madre de Dios & $\cdots$ & $11045^{\prime} 00^{\prime \prime S}$ & $71010^{\prime} 00^{\prime \prime}$ & & 400 P. Núñez 6147 & & 9/18/86 \\
\hline Uncaria guianensis & & мо & $* * *$ & Peru & Madre de Dios & $\cdots$ & $11050^{\circ} 00^{\prime \prime S}$ & $71025^{\prime} 00^{\prime \prime}$ & & 350 R. Foster 9571 & & $7 / 5 / 84$ \\
\hline Uncaria guianensis & & мо & $* * *$ & Peru & Madre de Dios & -.. & $11050^{\circ} 00^{\prime \prime} \mathrm{s}$ & $71025^{\prime} 00^{\prime \prime}$ & & 350 R. Foster 9680 & & $7 / 14 / 84$ \\
\hline Uncaria guianensis & & мо & **** & Peru & Madre de Dios & -.- & -.- & & -.- & P. Núñez et al.10431 & & $5 / 18 / 89$ \\
\hline Uncaria guianensis & & мо & $* * * *$ & Peru & Madre de Dios & -.. & -.- & & --. & S. Smith 420 & & $10 / 18 / 84$ \\
\hline Uncaria guianensis & & мо & $* * * *$ & Peru & Madre de Dios & $\cdots$ & -.- & & & 250 A. Gentry et al 19723 & & $4 / 24 / 77$ \\
\hline Uncaria guianensis & --- & USM & 111102 & Peru & Madre de Dios & Manú & $11052^{\prime 2} 24^{\prime S S}$ & $72022^{\prime} 12^{\prime \prime}$ & & 350 Burnham R.J. et al. & 781 & 17/10/1991 \\
\hline Uncaria guianensis & --- & AMAZ & 25659 & Peru & Madre de Dios & Tambopata & $12049^{\prime} 00^{\prime \prime S}$ & $69017^{\prime} 00^{\prime \prime}$ & & 260 Barboor P. & 5759 & $6 / 18 / 80$ \\
\hline Uncaria guianensis & -.- & AMAZ & 14425 & Peru & Madre de Dios & Tambopata & $12049^{\prime} 00^{\prime \prime S}$ & $69017^{\prime} 00^{\prime \prime}$ & & 260 Barbus $P$. & 5518 & $6 / 5 / 80$ \\
\hline Uncaria guianensis &.-- & AMAZ & 26667 & Peru & Madre de Dios & Tambopata & $12049^{\prime} 00^{\prime \prime S}$ & $69017^{\prime} 00^{\prime \prime}$ & & 260 Nuñez $P$. & 9323 & $7 / 21 / 88$ \\
\hline Uncaria guianensis & -- & USM & 117973 & Peru & Madre de Dios & Tambopata & $12019^{\circ} 00^{\prime \prime S}$ & $69040^{\prime} 00^{\prime \prime}$ & & 270 Gentry A. et al. & 51074 & $21 / 07 / 1985$ \\
\hline Uncaria guianensis & -.- & USM & 97222 & Peru & Madre de Dios & Tambopata & $12032^{\prime} 00^{\prime S} \mathrm{~S}$ & $69015^{\prime} 00^{\prime \prime}$ & & 240 Vasquez R. et al. & 12407 & 20/07/1989 \\
\hline Uncaria guianensis & --- & USM & 11374 & Peru & Madre de Dios & Tambopata & $12050^{\circ} 00^{\prime \prime S}$ & $69017^{\prime} 00^{\prime \prime}$ & & 260 Alexiades M. et al. & 921 & $21 / 08 / 1989$ \\
\hline Uncaria guianensis & --- & USM & 86713 & Peru & Madre de Dios & Tambopata & $12049^{\circ} 00^{\prime S} \mathrm{~S}$ & $69017^{\prime} 00^{\prime \prime}$ & & 260 Barbour P.J. & 5259 & $18 / 06 / 1980$ \\
\hline Uncaria guianensis & -- & USM & 49290 & Peru & Madre de Dios & Tambopata & $12049^{\circ} 00^{\prime \prime S}$ & $69017^{\prime} 00^{\prime \prime}$ & & 260 Gentry Al. et al & 19723 & $24 / 04 / 1977$ \\
\hline Uncaria guianensis & --- & AMAZ & 16286 & Peru & San Martín & Mariscal Cáceres & $08015^{\prime} 00^{\prime \prime S}$ & $76031^{\prime} 00^{\prime \prime}$ & & 450 Schunke-Vigo J. & 13619 & $5 / 18 / 82$ \\
\hline Uncaria guianensis & Garabata & USM & 41359 & Peru & San Martín & Mariscal Cáceres & $08015^{\prime} 00 " \mathrm{~S}$ & 76031'00" & & 400 Schunke V.J. & 8270 & $00 / 00 / 1977$ \\
\hline Uncaria guianensis & Garabato colorado & USM & 91794 & Peru & San Martín & Mariscal Cáceres & $08015^{\prime} 00 " \mathrm{~S}$ & $76031^{\prime} 00^{\prime \prime}$ & & 450 Schunke V.J. & sn & $18 / 05 / 1982$ \\
\hline Uncaria guianensis & Garabato colorado & USM & 9208 & Peru & San Martín & Mariscal Cáceres & $08015^{\prime} 00^{\prime \prime S}$ & $76031^{\prime} 00^{\prime \prime}$ & & 425 Schunke V.J. & 12538 & $3 / 2 / 81$ \\
\hline Uncaria guianensis & Garabato colorado & INPA & 116054 & Peru & San Martín & Tocache & $08011^{\prime} 00^{\prime \prime}$ & $76029^{\prime} 00^{\prime \prime}$ & & 450 Jose Schunke & 13619 & $5 / 18 / 82$ \\
\hline Uncaria guianensis & Garabata & INPA & 36175 & Peru & San Martín & Tocache & $08011^{\prime} 00^{\prime \prime}$ & $76029^{\prime} 00^{\prime \prime}$ & & 450 Schunke J. & 3889 & $4 / 11 / 70$ \\
\hline Uncaria guianensis & --- & USM & 45570 & Peru & Ucayali & Contamana & $07046^{\prime} 10^{\prime \prime S}$ & $75012^{\prime} 00^{\prime \prime}$ & & 170 Mc. Daniel S. & 14034 & 26/07/1970 \\
\hline Uncaria guianensis & Garabato & USM & 89743 & Peru & Ucayali & Coronel Portillo & $08023^{\prime} 00 " \mathrm{~S}$ & 74033'00" & & 250 Arce J. et al. & 15 & $14 / 02 / 1990$ \\
\hline
\end{tabular}




\begin{tabular}{|c|c|c|c|c|c|c|c|c|c|c|c|c|}
\hline $\begin{array}{l}\text { Espécie } \\
\text { N.científico }\end{array}$ & N. vulgar & $\begin{array}{l}\text { Herbário } \\
\text { Siggla }\end{array}$ & Registro & $\begin{array}{l}\text { Localidade } \\
\text { País }\end{array}$ & Estado & Município & $\begin{array}{l}\text { Latitude } \\
\quad\left({ }^{\circ} \mathrm{S}, \mathrm{S}\right)\end{array}$ & $\begin{array}{c}\text { Longitude } \\
\left({ }^{\circ}, \mathrm{W}\right)\end{array}$ & $\begin{array}{r}\text { Altitud } \\
\text { (manm }\end{array}$ & $\begin{array}{ll}\text { COLETOR } \\
& \text { Nome/número } \\
\end{array}$ & \multicolumn{2}{|c|}{ Data } \\
\hline Uncaria guianensis & --- & USM & 117250 & Peru & Ucayali & Coronel Portillo & $08050^{\circ} 00^{\prime \prime} \mathrm{S}$ & $74045^{\prime} 00^{\prime \prime}$ & & 210 Gentry Al. et al & 58391 & $15 / 06 / 1987$ \\
\hline Uncaria guianensis & Garabato & USM & 93100 & Peru & Ucayali & Coronel Portillo & $08023^{\prime} 00^{\prime \prime S}$ & $74033^{\prime} 00^{\prime \prime}$ & & 250 Arce J. et al. & sn & $25 / 08 / 1990$ \\
\hline Uncaria guianensis & -.- & USM & 110116 & Peru & Ucayali & Coronel Portillo & $08023^{\prime} 00^{\prime \prime S}$ & $74033^{\prime} 00^{\prime \prime}$ & & 250 Chávez F. & 98 & $13 / 01 / 1989$ \\
\hline Uncaria guianensis & & мо & $* * *$ & Suriname & ... & -.. & $05036^{\prime} 00^{\prime \prime} \mathrm{N}$ & $55010^{\prime} 00^{\prime \prime}$ & & 20 R. Evans et al 1855 & & $7 / 3 / 94$ \\
\hline Uncaria guianensis & -.- & MG & 25502 & Suriname & -.. & -.- & $03022^{\prime} 12^{\prime \prime} \mathrm{N}$ & $57020^{\prime} 36 "$ & & 180 Tresling & 236 & $7 / 26 / 00$ \\
\hline Uncaria guianensis & $\ldots$ & MG & 29155 & Suriname & ... & ... & $03022^{\prime} 122^{\prime \prime N}$ & $57020^{\prime} 36^{\prime \prime}$ & & 180 IFAT & 7848 & $00 / 09 / 1961$ \\
\hline Uncaria guianensis & Sipaliwini & HEO & 166821 & Suriname & -.. &.-- & $03022^{\prime} 12^{\prime \prime N}$ & $57020^{\prime} 36^{\prime \prime}$ & & 180 Evans R. & 1927 & $11 / 10 / 94$ \\
\hline Uncaria guianensis & -.- & HEO & 49582 & Suriname & ... & -.. & $03022^{\prime} 12^{\prime \prime N}$ & $57020^{\prime} 36^{\prime \prime}$ & & 180 Gonggrefp J. & 2169 & $6 / 10 / 16$ \\
\hline Uncaria guianensis & --- & INPA & 192260 & Suriname & -.- & -.- & $05036^{\prime} 00 " \mathrm{~N}$ & $55010^{\prime} 00^{\prime \prime}$ & & 20 Suriname & 1855 & $7 / 3 / 94$ \\
\hline Uncaria guianensis & ..- & INPA & 6974 & Suriname & ... & $\ldots$ & $03022^{\prime} 12^{\prime \prime N}$ & $57020^{\prime} 36^{\prime \prime}$ & & 180 Gonggryp J. & 3862 & $8 / 6 / 18$ \\
\hline Uncaria guianensis & -.- & $\mathrm{RB}$ & sn & Suriname & Pará & & $05036^{\prime} 00^{\prime \prime} \mathrm{N}$ & $55010^{\prime} 00^{\prime \prime}$ & & 20 R. Evans \& G. Lewis & 1855 & $7 / 3 / 94$ \\
\hline Uncaria guianensis & & мо & $* * * *$ & Suriname & Sipaliwini & -.. & $03022^{\prime} 12^{\prime \prime N}$ & $57020^{\prime} 36^{\prime \prime}$ & & 180 R.Evans ET AL. 1927 & & $11 / 10 / 94$ \\
\hline Uncaria guianensis & --- & INPA & 192289 & Suriname & Sipaliwini & -.- & $03022^{\prime} 12 " \mathrm{~N}$ & $57020^{\prime} 36^{\prime \prime}$ & & 180 Evans R. & 1927 & $11 / 10 / 94$ \\
\hline Uncaria guianensis & $\ldots$ & HEO & 166816 & Suriname & Zanderij & ... & $05036^{\prime} 00^{\prime \prime} \mathrm{N}$ & $55010^{\prime} 00^{\prime \prime}$ & & 20 Evans $\mathrm{R}$. & 1855 & 7/3/94 \\
\hline Uncaria guianensis & -.- & $\mathrm{RB}$ & 23154 & Venezuela & & (Rio Orinoco/Esmeralda) & & & & R.Spruce & 3221 & $00 / 12 / 1853$ \\
\hline Uncaria guianensis & & мо & $* * * *$ & Venezuela & Amazonas & -.. & $00050^{\prime} 00^{\prime \prime} \mathrm{N}$ & $66010^{\prime} 00^{\prime \prime}$ & & 140 R.Liesner 17454 & & $12 / 20 / 84$ \\
\hline Uncaria guianensis & Unha de gavilán & $\mathrm{RB}$ & 108626 & Venezuela & Amazonas & Esmeralda & (más arriba de & rinoco) & & $130 \mathrm{~L}$. Williams & 15495 & $5 / 19 / 42$ \\
\hline Uncaria guianensis & & мо & ***** & Venezuela & Anzoategui & ... & ... & & .-. & J. Steyermark 61174 & & $2 / 24 / 45$ \\
\hline Uncaria guianensis & & мо & $* * * *$ & Venezuela & Apure & ... & ... & & .-. & L. Aristeguieta et al. 4141 & & $3 / 1 / 60$ \\
\hline Uncaria guianensis & & мо & $* * * *$ & Venezuela & Bolívar & -.- & $06012^{\prime} 00^{\prime \prime} \mathrm{N}$ & $64028^{\prime} 00^{\prime \prime}$ & & 240 R. Liesner et al. 14029 & & $5 / 11 / 82$ \\
\hline Uncaria guianensis & & мо & $* * * *$ & Venezuela & Bolívar & -.. & -.- & & & 200 C.Benítez et al..5282 & & $5 / 14 / 95$ \\
\hline Uncaria guianensis & $\ldots$ & HEO & 15778 & Venezuela & Bolívar & Los Roses & $\ldots$ & ... & .-. & Blanco C. & 371 & $11 / 1 / 65$ \\
\hline Uncaria guianensis & $\ldots$ & $\mathrm{R}$ & 150326 & Venezuela & & (Por o rio Orinoco, mas n & a bacia baixa) & & & H.H.Rusby \& R.W. Squire & 212 & $00 / 05 / 1896$ \\
\hline Uncaria tomentosa & & мо & **** & Bolívia & Beni & -.. & $15010^{\prime} 00^{\prime \prime S}$ & $66037^{\prime} 00^{\prime \prime}$ & & 260 D.N. Smith et al. 14247 & & $8 / 25 / 90$ \\
\hline Uncaria tomentosa & ... & HUNB & sn & Bolívia & Beni & Moxos & $15010^{\prime} 00^{\prime \prime} \mathrm{S}$ & $66037^{\prime} 00^{\prime \prime}$ & & 260 Garcia E. & 14247 & $25 / 08 / 1990$ \\
\hline Uncaria tomentosa & -.. & HUNB & sn & Bolívia & Cochabamba & Carrasco & $17000^{\circ} 00^{\prime \prime S}$ & $64046^{\prime} 00^{\prime \prime}$ & & 235 Beck G. & 13695 & $27 / 10 / 1987$ \\
\hline Uncaria tomentosa & Bereoquida & HUNB & sn & Bolívia & La Paz & Iturralde & $13059^{\circ} 00^{\prime \prime S}$ & $67059^{\prime} 00^{\prime \prime}$ & & 280 Walt de $S$. & 12 & $14 / 03 / 1995$ \\
\hline Uncaria tomentosa & & LPB & **** & Bolívia & La Paz & Madidi & $14039^{\prime} 36^{\prime \prime S}$ & $67048^{\prime} 42^{\prime \prime}$ & & 340 A.Fuentes et al. 4084 & & $3 / 25 / 02$ \\
\hline Uncaria tomentosa & & USZ & $* * * *$ & Bolívia & Santa Cruz & ..- & $14055^{\circ} 00^{\prime \prime S}$ & $63033^{\prime} 00^{\prime \prime}$ & & 400 M.Saldías et al. 2301 & & $8 / 15 / 92$ \\
\hline Uncaria tomentosa & & мо & ***** & Bolívia & Santa Cruz & ... & $17036^{\circ} 00^{\prime \prime S}$ & $63036^{\circ} 00^{\prime \prime}$ & & 400 J.C.Salomon 14221 & & 9/2/85 \\
\hline Uncaria tomentosa & & NY & $* * *$ & Bolívia & Santa Cruz & ..- & ..- & & --. & M. Nee 49568 & & \\
\hline Uncaria tomentosa & -.- & HUNB & $\mathrm{sn}$ & Bolívia & Santa Cruz & Ichilo & $17036^{\prime} 00^{\prime \prime S}$ & $63036^{\circ} 00^{\prime \prime}$ & & 400 Salomon J.C. & 14221 & $2 / 10 / 85$ \\
\hline Uncaria tomentosa & & мо & $* * *$ & Brasil & Acre & Assis Brasil & -.- & & & 180 P.Núñez et al. 16991 & & 7/20/95 \\
\hline Uncaria tomentosa & -.- & USM & 142955 & Brasil & Acre & Assis Brasil & $10057^{\prime} 30^{\prime \prime S}$ & $69034^{\prime} 06^{\prime \prime}$ & & 180 Nuñez $P$. & 16991 & 20/07/1995 \\
\hline Uncaria tomentosa & Unha de Gato & UFAC & 15636 & Brasil & Acre & Cruzeiro do Sul & $07038^{\prime} 00^{\prime \prime S}$ & $72036^{\prime} 0^{\prime \prime}$ & & 150 M.E. Melo et al & 2 & $8 / 3 / 00$ \\
\hline Uncaria tomentosa & Unha de Gato & UFAC & 15637 & Brasil & Acre & Cruzeiro do Sul & $07038^{\prime} 00^{\prime \prime S}$ & $72036^{\prime} 00^{\prime \prime}$ & & 150 M.E. Melo et al & 3 & $8 / 3 / 00$ \\
\hline Uncaria tomentosa & Unha de Gato & UFAC & 15635 & Brasil & Acre & Cruzeiro do Sul & $07038^{\prime} 00^{\prime \prime S}$ & $72036^{\prime} 00^{\prime \prime}$ & & 150 M.E. Melo et al & 1 & $8 / 3 / 00$ \\
\hline Uncaria tomentosa &.-- & UFAC & 15647 & Brasil & Acre & Cruzeiro do Sul & $07028^{\prime} 16^{\prime \prime S}$ & $720566^{\prime} 58^{\prime \prime}$ & -.- & Raposo a et al. & 4 & 19/08/2001 \\
\hline Uncaria tomentosa & U. de gato, E. aí & UFAC & 16053 & Brasil & Acre & Feijó & $08012 ' 53,3 " \mathrm{~S}$ & $70020^{\prime} 22^{\prime \prime}$ & --- & a Raposo et al & 5 & $8 / 20 / 01$ \\
\hline Uncaria tomentosa & U. de gato, E. aí & UFAC & 15645 & Brasil & Acre & Feijó & $08012 ' 53,3 " \mathrm{~S}$ & $70020^{\prime} 22^{\prime \prime}$ & & “ Raposo et al & 6 & $8 / 20 / 01$ \\
\hline
\end{tabular}




\begin{tabular}{|c|c|c|c|c|c|c|c|c|c|c|c|c|}
\hline \multirow{2}{*}{$\begin{array}{l}\text { Espécie } \\
\text { N.científico }\end{array}$} & \multirow[b]{2}{*}{ N. vulgar } & \multicolumn{2}{|l|}{ Herbário } & \multicolumn{3}{|l|}{ Localidade } & \multirow[b]{2}{*}{$\begin{array}{l}\text { Latitude } \\
\quad\left({ }^{\circ} \mathrm{S}, \mathrm{S}\right)\end{array}$} & \multirow[b]{2}{*}{$\begin{array}{c}\text { Longitude } \\
\left({ }^{\circ} \mathrm{S}, \mathrm{W}\right)\end{array}$} & \multicolumn{2}{|r|}{ COLETOR } & \multirow{2}{*}{\multicolumn{2}{|c|}{ Data }} \\
\hline & & Sigla & Registro & País & Estado & Município & & & Altitude & Nome/número & & \\
\hline Uncaria tomentosa & Espera-aí & UFAC & 16053 & Brasil & Acre & Feijó & $08012 \cdot 53 " \mathrm{~S}$ & $70020^{\prime 22} "$ & -.- & Raposo a et al. & $\mathrm{sn}$ & $20 / 08 / 2001$ \\
\hline Uncaria tomentosa & -.- & UFAC & 15645 & Brasil & Acre & Feijó & 08012'53"S & $70020^{\prime} 22^{\prime \prime}$ & -.- & Raposo a et al. & 6 & 20/08/2001 \\
\hline Uncaria tomentosa & Espera-aí & UFAC & sn & Brasil & Acre & Manoel Urbano & $08043 ' 52 " \mathrm{~S}$ & 69031'01" & --. & Silva J.M.M. et al. & 1 & 3/9/02 \\
\hline Uncaria tomentosa & ..- & NY & $* * *$ & Brasil & Acre & Tarauacá & $08020^{\prime} 43 " \mathrm{~S}$ & $71011^{\prime} 59^{\prime \prime}$ & -.- & D.C.Daly et al. 8556 & & $11 / 16 / 95$ \\
\hline Uncaria tomentosa & Jupinda & $\mathrm{RB}$ & 101679 & Brasil & Amapá & Macapá & $01036^{\prime} 00^{\prime \prime} \mathrm{N}$ & $51058^{\prime} 00^{\prime \prime}$ & & E. Pereira \& Egler & 3415 & $11 / 3 / 57$ \\
\hline Uncaria tomentosa & Jupindá & MG & 22618 & Brasil & Amapá & Macapá & $01036^{\prime} 00^{\prime \prime} \mathrm{N}$ & $51058^{\prime} 00^{\prime \prime}$ & -.- & Egler $\mathrm{W}$. & 684 & $10 / 3 / 57$ \\
\hline Uncaria tomentosa & U. de gato, E. aí & UFAC & 16055 & Brasil & Amazonas & Boca do Acre & $08040^{\prime} 00 " \mathrm{~S}$ & $67022^{\prime} 00^{\prime \prime}$ & & J.M.N. Silva et al & sn & $9 / 20 / 01$ \\
\hline Uncaria tomentosa & -- & INPA & 55269 & Brasil & Amazonas & Tefé & 03022'00"S & $64042^{\prime} 00^{\prime \prime}$ & -- & Danttas M. & 12394 & $10 / 5 / 72$ \\
\hline Uncaria tomentosa & --. & $\mathrm{RB}$ & 15691 & Brasil & Pará & (Paraná de Alemeirim & argem) & & & "Ducke & sn & $11 / 14 / 19$ \\
\hline Uncaria tomentosa & -- & MG & 15169 & Brasil & Pará & Rio Branco de Ôbidos & $\cdots$ & $\cdots$ & -- & Ducke A. & sn & $12 / 16 / 13$ \\
\hline Uncaria tomentosa & --. & мо & $* * * *$ & Colômbia & Antioquia & -.. & $07005^{\prime} 00^{\prime \prime} \mathrm{N}$ & $74015^{\prime} 00^{\prime \prime}$ & & 60 Callejas et al. 5302 & & 9/17/87 \\
\hline Uncaria tomentosa & --. & $\mathrm{CR}$ & **** & Costa Rica & Alajuela & --. & $10054^{\prime} 50^{\prime \prime} \mathrm{N}$ & $84046^{\prime} 05^{\prime \prime}$ & & 40 K.Martinez et al. 163 & & 6/22/93 \\
\hline Uncaria tomentosa & ..- & мо & $* * * *$ & Costa Rica & Heredia & $\ldots$ & $10020^{\prime} 00^{\prime \prime} \mathrm{N}$ & $84000^{\circ} 00^{\prime \prime}$ & -.- & A.Gentry 1039 & & $6 / 28 / 71$ \\
\hline Uncaria tomentosa & -.- & мо & $* * * *$ & Equador & Los Rios & -.- & -.. & & & 70 A.Gentry et al. 30742 & & $1 / 24 / 81$ \\
\hline Uncaria tomentosa & --. & мо & ***** & Equador & Moroña-Santiago & -.- & -.- & & & 00 Limbach 133 & & \\
\hline Uncaria tomentosa & --. & мо & **** & Equador & Sucumbios & --. & $00 \mathrm{o} 20^{\prime} 00^{\prime \prime} \mathrm{S}$ & $76040^{\prime} 00^{\prime \prime}$ & & 50 D.Neill 10428 & & 6/26/95 \\
\hline Uncaria tomentosa & ..- & мо & $* * * *$ & Equador & Sucumbios & $\ldots$ & $00020^{\prime} 00^{\prime \prime S}$ & $76040^{\circ} 00^{\prime \prime}$ & & 50 D.Neill 10427 & & $6 / 26 / 95$ \\
\hline Uncaria tomentosa & -- & мо & $* * * *$ & Guatemala & Izabal & -.. & $15030^{\prime} 00^{\prime \prime} \mathrm{N}$ & $89000^{\prime} 00^{\prime \prime}$ & --. & E.Contreras 10773 & & $5 / 12 / 71$ \\
\hline Uncaria tomentosa &.-- & мо & $* * * *$ & Guiana & Demerara-B. & -.. & $06027^{\prime} 00^{\prime \prime} \mathrm{N}$ & $58035^{\prime} 00^{\prime \prime}$ & & 5 Henkel T.W et al 2090 & & $5 / 18 / 93$ \\
\hline Uncaria tomentosa & --. & мо & **** & Guiana & Barima-Waini & --. & $07030^{\prime} 00^{\prime \prime} \mathrm{N}$ & $60008^{\prime} 00^{\prime \prime}$ & & 07 T.McDowell et al. 4516 & & $4 / 30 / 91$ \\
\hline Uncaria tomentosa & -.- & мо & $* * * *$ & Nicaragua & ... & -.. & $11008^{\prime} 00^{\prime \prime} \mathrm{N}$ & $84021^{\prime} 00^{\prime \prime}$ & & 50 R. Rueda et al. 10497 & & $3 / 17 / 99$ \\
\hline Uncaria tomentosa & ... & мо & $* * * *$ & Nicaragua & ... & ... & $11020^{\prime} 00^{\prime \prime} \mathrm{N}$ & $84035^{\prime} 00^{\prime \prime}$ & $\ldots$ & J. Salick et al. 8420 & & $6 / 28 / 97$ \\
\hline Uncaria tomentosa & -.- & мо & $* * * *$ & Nicaragua & Jinotega & -.. & $13033^{\prime} 00 " \mathrm{~N}$ & $85019^{\prime} 00^{\prime \prime}$ & & 50 R. Rueda et al. 7408 & & 9/9/97 \\
\hline Uncaria tomentosa & -.- & мо & $* * *$ & Nicaragua & Jinotega & -.. & $13059^{\prime} 00^{\prime \prime} \mathrm{N}$ & $85019^{\prime} 00^{\prime \prime}$ & & 00 R. Rueda et al. 7924 & & $2 / 19 / 98$ \\
\hline Uncaria tomentosa & --- & мо & $* * * *$ & Nicaragua & San Juan & -.- & $11002^{\prime} 00^{\prime \prime} \mathrm{N}$ & $83054^{\prime} 00^{\prime \prime}$ & & 20 R. Rueda et al. 4704 & & $7 / 30 / 96$ \\
\hline Uncaria tomentosa & -.- & мо & $* * * *$ & Nicaragua & San Juan & -.- & $11002^{\prime} 00^{\prime \prime} \mathrm{N}$ & $83054^{\prime} 00^{\prime \prime}$ & -.- & R. Rueda et al. 4712 & & $7 / 30 / 96$ \\
\hline Uncaria tomentosa & ... & мо & $* * * *$ & Nicaragua & San Juan & ... & $10045^{\prime} 00 " \mathrm{~N}$ & $83059^{\prime} 00^{\prime \prime}$ & & 30 R. Rueda et al. 1919 & & $7 / 10 / 94$ \\
\hline Uncaria tomentosa & -.- & мо & $* * * *$ & Nicaragua & San Juan & -.. & $11007^{\prime} 00^{\prime \prime} \mathrm{N}$ & $84022^{\prime} 00^{\prime \prime}$ & & 00 R. Rueda et al. 15097 & & $11 / 22 / 00$ \\
\hline Uncaria tomentosa & -.- & мо & $* * * *$ & Nicaragua & San Juan & -.- & $11010^{\prime} 00^{\prime \prime} \mathrm{N}$ & $84028^{\prime} 00^{\prime \prime}$ & & 20 P.P. Moreno 27232 & & $2 / 12 / 90$ \\
\hline Uncaria tomentosa & ... & мо & $* * * *$ & Nicaragua & Zelaya & ... & $11022^{\prime} 00^{\prime \prime N}$ & $840011^{\prime} 00^{\prime \prime}$ & & 75 R. Rueda et al. 10239 & & $1 / 17 / 99$ \\
\hline Uncaria tomentosa & --- & мо & $* * * *$ & Nicaragua & Zelaya & -.- & $14040^{\circ} 00^{\prime \prime} \mathrm{N}$ & $84007^{\prime} 00^{\prime \prime}$ & & 00 Pipoly, J. 3740 & & $3 / 2 / 79$ \\
\hline Uncaria tomentosa & -.. & мо & $* * * *$ & Nicaragua & Zelaya & -.. & $13029^{\prime} 00^{\prime \prime} \mathrm{N}$ & $84013^{\prime} 00^{\prime \prime}$ & & 9 D.Stevens et al. 19529 & & $3 / 7 / 81$ \\
\hline Uncaria tomentosa & -.- & мо & $* * * *$ & Nicaragua & Zelaya & -.- & $13029^{\prime} 00^{\prime \prime} \mathrm{N}$ & $84013^{\prime} 00^{\prime \prime}$ & & 9 D.Stevens 8263 & & $4 / 26 / 78$ \\
\hline Uncaria tomentosa & -.- & мо & $* * * *$ & Nicaragua & Zelaya & -.- & $11035^{\circ} 00^{\prime \prime N}$ & $84021^{\prime} 00^{\prime \prime}$ & & 90 J.C.Sandino 3326 & & $7 / 29 / 82$ \\
\hline Uncaria tomentosa & ..- & мо & $* * * *$ & Nicaragua & Zelaya & ... & $13048^{\prime} 00^{\prime \prime} \mathrm{N}$ & $84024^{\prime} 00^{\prime \prime}$ & & 75 R. Rueda et al. 6764 & & $7 / 10 / 97$ \\
\hline Uncaria tomentosa & -.- & мо & $* * *$ & Nicaragua & Zelaya & ... & $13048^{\prime} 00^{\prime \prime} \mathrm{N}$ & $84026^{\circ} 00^{\prime \prime}$ & & 75 R. Rueda et al. 6838 & & $7 / 12 / 97$ \\
\hline Uncaria tomentosa & ..- & мо & $* * * *$ & Nicaragua & Zelaya & ..- & $13000^{\circ} 00^{\prime \prime} \mathrm{N}$ & $84030^{\circ} 00^{\prime \prime}$ & & 10 Ortiz, F. 540 & & $1 / 6 / 83$ \\
\hline Uncaria tomentosa & ..- & мо & $* * * *$ & Nicaragua & Zelaya & $\ldots$ & $13000^{\prime} 00^{\prime \prime} \mathrm{N}$ & $84030^{\prime} 00^{\prime \prime}$ & $\ldots$ & A. Molina 2256 & & $4 / 21 / 49$ \\
\hline
\end{tabular}


Tabela 6. Informação do material botânico nos herbários do gênero Uncaria

(Continuação)

\begin{tabular}{|c|c|c|c|c|c|c|c|c|c|c|c|c|}
\hline \multirow{2}{*}{$\begin{array}{l}\text { Espécie } \\
\text { N.científico }\end{array}$} & \multirow[b]{2}{*}{ N. vulgar } & \multicolumn{2}{|l|}{ Herbário } & \multicolumn{3}{|l|}{ Localidade } & \multirow[b]{2}{*}{ 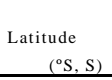 } & \multirow[b]{2}{*}{$\begin{array}{r}\text { Longitude } \\
\left({ }^{\circ} \mathrm{S}, \mathrm{W}\right) \\
\end{array}$} & \multirow[b]{2}{*}{ Altitude } & \multicolumn{3}{|l|}{ COLETOR } \\
\hline & & Sigla & Registro & País & Estado & Município & & & & $\begin{array}{l}\text { e Nome/número } \\
1 .)\end{array}$ & & \\
\hline Uncaria tomentosa & -- & мо & $* * *$ & Nicaragua & Zelaya & -.. & $13000^{\circ} 00^{\prime \prime} \mathrm{N}$ & $84030^{\prime} 00^{\prime \prime}$ & & 150 Neill, D. 3983 & & $5 / 13 / 78$ \\
\hline Uncaria tomentosa & -- & мо & $* * *$ & Nicaragua & Zelaya & $\cdots$ & $14 \mathrm{o} 01^{\circ} 00 " \mathrm{~N}$ & $84034^{\prime} 00^{\prime \prime}$ & & 140 D. Stevens 8048 & & $4 / 24 / 78$ \\
\hline Uncaria tomentosa & -.- & мо & $* * *$ & Nicaragua & Zelaya & -.. & $14004^{\prime} 00^{\prime \prime} \mathrm{N}$ & $84034^{\prime} 00^{\prime \prime}$ & & 200 R. Rueda et al. 6602 & & 6/2/97 \\
\hline Uncaria tomentosa & -.. & мо & $* * *$ & Nicaragua & Zelava & -.. & $13058^{\prime} 00^{\prime \prime} \mathrm{N}$ & $84037^{\prime} 00^{\prime \prime}$ & & 260 D.Stevens 12467 & & $2 / 21 / 79$ \\
\hline Uncaria tomentosa & $--\cdot$ & мо & ${ }^{* * *}$ & Nicaragua & Zelaya & $\cdots$ & $13008^{\prime} 00 " \mathrm{~N}$ & $84055^{\prime} 00^{\prime \prime}$ & & 90 P.Moreno 23769 & & $3 / 18 / 84$ \\
\hline Uncaria tomentosa & $-\cdot$ & мо & **** & Nicaragua & Zelaya & & $13036^{\prime} 00^{\prime \prime} \mathrm{N}$ & $85005^{\prime} 00^{\prime \prime}$ & & 150 W.D.Stevens 7452 & & $3 / 18 / 78$ \\
\hline Uncaria tomentosa & 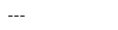 & мо & $* * *$ & Panamá & Área do Canal & $\cdots$ & $09 \mathrm{o} 10^{\prime} 00 " \mathrm{~N}$ & $79045^{\prime} 00^{\prime \prime}$ & $\cdots$ & T. Croat 8288 & & 2/28/69 \\
\hline Uncaria tomentosa & -.. & мо & $* * *$ & Panamá & Área do Canal & -.. & $09010^{\prime} 00^{\prime \prime} \mathrm{N}$ & $79045^{\prime} 00^{\prime \prime}$ & $\ldots$ & C.Wilson 72 & & $2 / 28 / 31$ \\
\hline Uncaria tomentosa & -.. & мо & $* * *$ & Panamá & Darién & $\ldots$ & $08 \mathrm{o} 13^{\prime} 00 " \mathrm{~N}$ & $77054^{\prime} 00^{\prime \prime}$ & $\ldots$ & J.A.Duke 14554 & & $10 / 1 / 67$ \\
\hline Uncaria tomentosa & $-\cdot$ & USM & 14823 & Peru & $\cdots$ & $\cdots$ & -- & $\cdots$ & $\cdots$ & Schunke V.J. & 10506 & sd \\
\hline Uncaria tomentosa & $--\cdot$ & мо & $* * *$ & Peru & Amazonas & Ipacuma & -- & & $\cdots$ & J. Albán et al. 10894 & & $8 / 12 / 80$ \\
\hline Uncaria tomentosa & Uña de gato & USM & 139983 & Peru & Amazonas & Bagua & $04055^{\prime} 00 " \mathrm{~S}$ & 78019'00" & & 475 Díaz C. et al. & 7686 & 21/10/1995 \\
\hline Uncaria tomentosa & -- & USM & 138032 & Peru & Amazonas & Bagua & $05003^{\prime} 20 " \mathrm{~S}$ & $78020^{\prime 2} 23^{\prime \prime}$ & & 650 Díaz C. et al. & 8176 & sd \\
\hline Uncaria tomentosa &.-- & USM & 142863 & Peru & Huánuco & Puerto Inca & $09022^{\prime} 00^{\prime \prime}$ & $75000^{\prime} 00^{\prime \prime S}$ & & 265 Obregón L. & 1 & 19/04/1999 \\
\hline Uncaria tomentosa & $--\cdot$ & USM & 64477 & Peru & Huánuco & Puerto Inca & $09022^{\prime} 00^{\prime \prime}$ & $75000^{\prime} 00 " \mathrm{~S}$ & & 265 Foster R. & 8767 & $14 / 09 / 1982$ \\
\hline Uncaria tomentosa & $-\cdot$ & USM & sn & Peru & Huánuco & Puerto Inca & $09022^{\prime} 00^{\prime \prime}$ & $75000^{\prime} 00^{\prime \prime} \mathrm{s}$ & & 265 Castro G. & sn & sd \\
\hline Uncaria tomentosa & -- & USM & 84880 & Peru & Junín & Chanchamayo & $10055^{\prime} 00 " \mathrm{~S}$ & $75005^{\prime} 00^{\prime \prime}$ & & 500 Cerrate E. et al. & 8455 & $27 / 08 / 1982$ \\
\hline Uncaria tomentosa & -- & USM & 101042 & Peru & Loreto & Alto Amazonas & $02055^{\prime} 00^{\prime \prime S}$ & $76015^{\prime} 00^{\prime \prime}$ & & 220 Lewis W.H. et al. & 10407 & 29/12/1985 \\
\hline Uncaria tomentosa & $--\cdot$ & AMAZ & 28403 & Peru & Loreto & Mavnas & $03 \mathrm{o} 40^{\prime} 00^{\prime \prime} \mathrm{S}$ & $73054^{\prime} 00^{\prime \prime}$ & & 160 Revilla J. & 1933 & $11 / 26 / 76$ \\
\hline Uncaria tomentosa & $--\cdot$ & USM & 41969 & Peru & Loreto & Maynas & $01010^{\prime} 00 " \mathrm{~S}$ & 74044'00" & & 100 Mathias M.E. et al & 5477 & 9/7/61 \\
\hline Uncaria tomentosa & 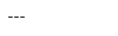 & USM & 124323 & Peru & Loreto & Maynas & $01010^{\prime} 00^{\prime \prime S}$ & 74044'00" & & 100 Vásquez Ret al. & 13043 & $5 / 11 / 89$ \\
\hline Uncaria tomentosa & -.- & USM & 99290 & Peru & Loreto & Maynas & $01010^{\prime} 00^{\prime \prime S}$ & 74044'00" & & 100 Lewis W.H. et al. & 10176 & $3 / 12 / 85$ \\
\hline Uncaria tomentosa & $--\cdot$ & мо & $* * *$ & Peru & Madre de Dios & $\cdots$ & $12055^{\prime} 00^{\prime \prime S}$ & $71012^{\prime} 00^{\prime \prime}$ & & 500 R. Foster et al. 7320 & & $12 / 9 / 83$ \\
\hline Uncaria tomentosa & -.. & мо & $* * *$ & Peru & Madre de Dios & & -.- & & & 760 P. Núñez et al. 14686 & & $12 / 8 / 91$ \\
\hline Uncaria tomentosa & $--\cdot$ & USM & 92729 & Peru & Madre de Dios & Manú & $11052^{\prime} 00 " \mathrm{~S}$ & $71022^{\prime} 00^{\prime \prime}$ & & 400 Foster R. et al. & 7320 & 9/12/83 \\
\hline Uncaria tomentosa & -- & мо & $* * *$ & Peru & Madre de Dios & Tambopata & $12049^{\prime} 00^{\prime \prime S}$ & $69040^{\prime} 00^{\prime \prime}$ & & 270 A.Gentry et al. 51074 & & $7 / 21 / 85$ \\
\hline Uncaria tomentosa & -- & USM & 135656 & Peru & Madre de Dios & Tambopata & $12057^{\prime} 00 " \mathrm{~S}$ & $68053^{\prime} 00^{\prime \prime}$ & & 200 Beltrán H. et al. & 2434 & $23 / 06 / 1996$ \\
\hline Uncaria tomentosa & -.. & USM & 128772 & Peru & Madre de Dios & Tambopata & $12040^{\prime} 00^{\prime \prime} \mathrm{S}$ & $69017^{\prime} 00^{\prime \prime}$ & & 260 Alexiades M. et al. & 1026 & $15 / 08 / 1990$ \\
\hline Uncaria tomentosa & -.. & USM & 91791 & Peru & Madre de Dios & Tambopata & $12050^{\prime} 00^{\prime \prime} \mathrm{S}$ & $69020^{\prime} 00^{\prime \prime}$ & $\ldots$ & Smith S.F. et al. & 420 & $18 / 10 / 1984$ \\
\hline Uncaria tomentosa & -.- & USM & 145206 & Peru & Pasco & Oxаратра & $10 \mathrm{o} 30^{\prime} 00^{\prime \prime} \mathrm{S}$ & $75017^{\prime} 00^{\prime \prime}$ & $\cdots$ & Smith S.F. et al. & 6430 & $17 / 03 / 1984$ \\
\hline Uncaria tomentosa & -- & мо & $* * *$ & Peru & Puno & $\cdots$ & $13030^{\prime} 00^{\prime \prime S}$ & $69050^{\prime} 00^{\prime \prime}$ & & 775 A.Gentry et al. 77343 & & $5 / 29 / 92$ \\
\hline Uncaria tomentosa & -- & мо & $* * *$ & Peru & San Martín & $\cdots$ & -- & & & 615 J.Schunke-V. 10722 & & $1 / 20 / 79$ \\
\hline Uncaria tomentosa & -- & USM & 59940 & Peru & San Martín & Mariscal Cáceres & $08015^{\prime} 00^{\prime \prime S}$ & 76031'00" & & 425 Schunke V.J. & 13489 & $3 / 3 / 82$ \\
\hline Uncaria tomentosa & -.. & USM & 13619 & Peru & San Martín & Mariscal Cáceres & $08015^{\prime} 00^{\prime \prime} \mathrm{S}$ & $76031^{\prime} 00^{\prime \prime}$ & & 425 Schunke V.J. & 13619 & $18 / 05 / 1982$ \\
\hline Uncaria tomentosa & --- & USM & 91792 & Peru & San Martín & Tocache & $08011^{\prime} 00^{\prime \prime}$ & $76029^{\prime} 00^{\prime \prime}$ & & 450 Schunke V.J. & 14215 & $9 / 1 / 86$ \\
\hline Uncaria tomentosa & -- & мо & $* * *$ & Peru & Ucayali & $\cdots$ & $08050^{\prime} 00^{\prime \prime} \mathrm{S}$ & $74045^{\prime} 00^{\prime \prime}$ & & 200 A.Gentry et al. 58391 & & $6 / 15 / 87$ \\
\hline Uncaria tomentosa & -.. & MO & $* * *$ & Peru & Ucayali & $\ldots$ & $045900^{\prime \prime S}$ & $75035^{\prime} 00^{\prime \prime}$ & -.. & C. Díaz et al. 890 & & $1 / 23 / 79$ \\
\hline Uncaria tomentosa & -.- & MO & $* * *$ & Peru & Ucayali & & -.- & & -.. & J.Schunke 14275 & & $3 / 13 / 89$ \\
\hline Uncaria tomentosa & -- & MO & $* * *$ & Peru & Ucavali & Coronel Portillo & $08041^{\prime} 00 " \mathrm{~S}$ & $75000^{\prime} 00^{\prime \prime}$ & & 270 A. Gentry, et al. 31201 & & $2 / 11 / 81$ \\
\hline Uncaria tomentosa & -- & $\mathrm{R}$ & 198391 & Peru & Ucayali & Purus & $10 \mathrm{o} 04^{\prime} 00 " \mathrm{~S}$ & $71006^{\prime} 00^{\prime \prime}$ & & 250 J. Graham \& V. Schunke & 287 & $10 / 28 / 97$ \\
\hline Uncaria tomentosa & $\cdots$ & мо & $* * *$ & Venezuela & Bolívar & $\cdots$ & $07030^{\prime} 00^{\prime \prime} \mathrm{N}$ & $63010^{\prime} 00^{\prime \prime}$ & & 335 R.Liesner et al. 11396 & & $4 / 7 / 81$ \\
\hline Uncaria tomentosa & -- & мо & $* * *$ & Venezuela & Bolívar & $\cdots$ & $07028^{\prime} 00^{\prime \prime} \mathrm{N}$ & $63014^{\prime} 00^{\prime \prime}$ & & 425 R.Liesner et al. 11464 & & $4 / 10 / 81$ \\
\hline Uncaria tomentosa & $\ldots$ & мо & $* * *$ & Venezuela & Zulia & $\ldots$ & $09_{\mathrm{o}} 26^{\prime} 00^{\prime \prime} \mathrm{N}$ & $72033^{\prime} 00^{\prime \prime}$ & & 40 G.Davidse et al. 18330 & & $6 / 20 / 80$ \\
\hline
\end{tabular}


Tabela 7. Resultados do diagnóstico do status de conservação das espécies dos gêneros Cinchona, Croton e Uncaria

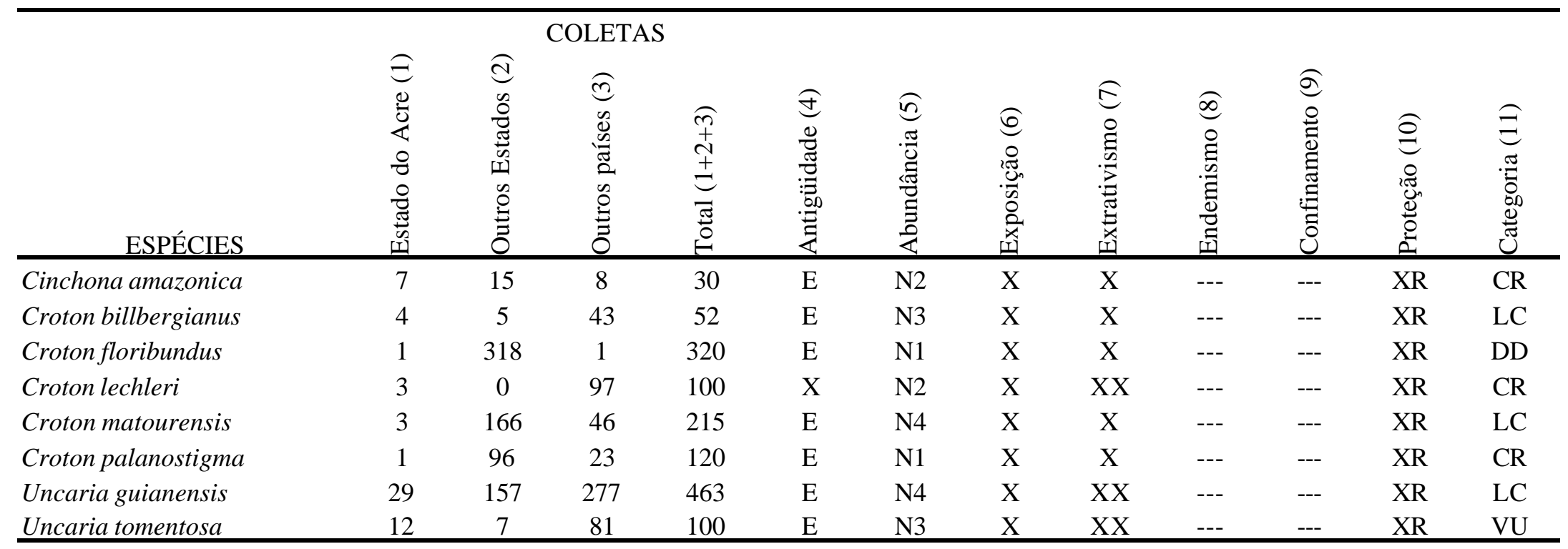

(4) X=após de 1990; E=escassez ou $+70 \%$ antes de 1990 ; $0=$ sem coleta

(5) N1 muito rara; N2=rara; N3=Comum; N4=muito abundante

(6) $\mathrm{X}=$ troca de localização; $\mathrm{XX}=$ centro de ocorrência

(7) $\mathrm{X}=$ extrativismo da espécie; $\mathrm{XX}$ maior extrativismo

(8) $\mathrm{X}=$ espécie total ou sustancialmente endémica
(9) $\mathrm{X}=$ espécie confinada ao Estado do Acre

(10) $\mathrm{X}=$ espécie protegida em área protegida; $\mathrm{XR}=$ dúvida, sem registro

(11) $\mathrm{CR}=$ perigo crítico; $\mathrm{DD}=$ informação disponível inadequada ;

$\mathrm{LC}=$ comuns e abundantes, fora de perigo; VU=perigo a mediano prazo 


\section{REFERÊNCIAS BIBLIOGRÁFICAS}

ACOSTA, S. Maderas económicas del Ecuador e sus usos . Quito, Ecuador: Ed. Casa de la Cultura Ecuatoriana, 1960. 328p.

AGUIAR, L. M.; MATOS, F. J. A.; MOURA, V. L.; ALBURQUERQUE, D.E. Atividade antibiótica de plantas medicinais da flora nordestina. Acta Amazônica, v.18, n .1/2, p.89-90, 1988.

ALARCÓN, R.; MENA, P. Etnobotánica, valoración econónica y comercialización de recursos florísticos silvestres en el alto Napo-Ecuador. Ecociencia, v.1, p,161-162, 1994.

ALBURQUERQUE, S. G. Caatinga vegetation dynamics under various grazing intensities by steers in the semi-arid Northeast, Brazil. Journal of Range Management, v.52, n .3, p.241-248, 1999.

ALCIR, B. T.; LIMA, S.F.; OLIVERA, W. Caracterização anatômica da madeira de avuvuia (Croton matourensis Aubl.) ocorrente em floresta secundária no municipio de Bragança, Estado do Pará. In: CONGRESSO NACIONAL DE BOTÂNICA 50., Natal, Rio Grande do Norte-Brasil, 1999/Blumenau, v.1, 1999. p.41 (Livro de Resumos)

ALLEM, A. C. Preliminares para uma abordagem taxonômica do gênero Croton L. (Euphorbiaceae) do Rio Grande do Sul. Boletim do Museu Municipal de Botânica, v. 34, p.1-33, 1978.

ALVES, E.S.; ANGYLOSSY-ALFONSO, V. Ecological trends in the wood anatomy of some Brazilian species: growth rings and vassels. IAWA Journal, v.21, n.1, p.3-30, 2000 .

ALVES, E.S.; ANGYLOSSY-ALFONSO, V. Ecological trends in the wood anatomy of some Brazilian species: axial parenchyma, rays and fibres. IAWA Journal, v.23, n.4, p.3-30, 2002.

AMARAL, A. C. F.; BARNES, R. A. Alkaloids of Croton celtidifolius. Núcleo de Pesquisas de Produtos Naturais. Planta Medica, v.63, n.5, p.485, 1997. 
AMÉRICO, A. P.; LOBATO, V. R.; CARVALHO, R. A.; BRASIL, D. ; SETTE, I.M. LIMA, K.V. Avaliação fitoquímica e da toxicidade de Croton matourensis Aublet. (maravuvuia). Brasilia: Instituto Brasileiro de Defesa do Usuário de Medicamentos, 2002. 12p. (relatório técnico).

ANDERSSON, L.A. Uncaria. Flora de Ecuador. v. 50, p.106-109, 1994.

ANDERSSON, L. A. Tribes and genera of the Cinchoneae complex (Rubiaceae) in: INTERNATIONAL CONFERENCE ON THE RUBIACEAE, 1., St. Louis Missouri, 1993. Annals of the Missouri Botanical Garden, v. 82, n.3, p.409-427, 1995.

ANDERSSON, L. A. Revision of the genus Cinchona (Rubiaceae-Cinchoneae). Memories The New York Botanical Garden, v. 80, p.1-75, 1998.

ANDERSSON, L. A.; PERSSON, C. Circumscription of the tribe Cinchoneae Rubiaceae)-A cladistic approach. Plant Systematics and Evolution, v.178, p.65-94, 1991.

ANDERSSON, L. A.; CHURCHILL, S. P.; BALSLEV, H.; FORERO, E.; LUTEYN, J. L. Diversity and origins of Andean Rubiaceae in: BIODIVERSITY AND CONSERVATION OF NEOTROPICAL MONTANE FORESTS SYMPOSIUM, New York: , 21-26 June, 1993. Memories The New York Botanical Garden, New York. Lubrecht and Cramer, 1995. p.441-450.

ANGIOSPERM PHYLOGENY GROUP-APG. An update Angiosperm Phylogeny Grup classification for the orders and families of flowering plantas. Botanical Journal of the Linnean Society, v.141, n.4, p.399-439, 2003.

ANTUNES, O. A. C., PINTO, A. C., CORREIA, C. R. D., REZENDE, C. M. Utilização do sistema cromato de tbutila/Hidroperóxido de tbutila na oxidação catalítica de monoterpenos de copiaba. Revista da Universidade Rural. Série Ciências da Vida, v. 16, p.15-19, 1998.

AQUINO, R.; SIMONE, F.; PIZZA, C.; CONTI, C.; STEIN, M. L. Plant metabolites: structure and in vitro antiviral activity of quinovic acid glycosides from Uncaria tomentosa and Guettarda platypoda. Journal of Natural Products, v.52, p.679-685, 1989.

AQUINO, R.; DE-FEO, V.; SIMONE, F.; PIZZA, C.; CIRINO, G. Plant metabolites: new compounds and anti-inflammatory activity of Uncaria tomentosa. Journal of Natural Products, v.54, p.453-459, 1991.

ARAÚJO, V. C.; CORREA, G. C.; MAIA, J. G. S.; DASILVA, M. L.; GOTTLIEB, O. R.; MARX, M. C.; MAGALHAES, M. T. Essential oils of Amazonia containing linalool. Acta Amazonica, v.1, n.3, p.45-47, 1971. 
ARAÚJO, V. F. A crise da borracha no primeiro surto e as tentativas de evitar o colapso (1910 -1920). Rio Branco-Acre, Brasil, 1999. 98p. Monografia (Graduação), Departamento de História-Universidade Federal do Acre.

ARENS, K.; LECHTHALER, R. Estudo anatômico da madeira de açacu, visando o seu aproveitamento para fabricação de celulose. Rio de Janeiro: Conselho Nacional de Pesquisa, 1958. 27p. (Publicação, 6).

ARMBRUSTER, W. S.; DI-STILIO, V. S.; TUXILL, J. D.; FLORES T. C.; RUNK, J. L.; BERG, R. L. Covariance and decoupling of floral and vegetative traits in nine Neotropical plants: a re-evaluation of Berg's correlation pleiades concept. American Journal of Botany, v. 86, n.1. p.39-51, 1999.

BARAJAS-MORALES, J.; ECHENIQUE-MANRIQUE, R. Anatomía de maderas 12 especies de Jalisco y Veracruz-México. Publicación del Instituto de Investigaciones de Recursos Bióticos, v.1, n.2, p.29-70, 1976.

BARQUERO A. El cultivo del árbol de la Quina. Costa Rica: Colegio de Ingeniero de Agrónomos. 1986. 13p.

BARTH, O. M.; DA-LUZ, C. F. P. Melissopalynological data obtained from a mangrove area near to Rio de Janeiro, Brazil. Journal of Apicultural Research, v.37, n.3, p.155-163, 1998.

BASTIEN, H. C. Distribution study of Croton drago: a report for Shaman Fharmaceuticals. San Francisco, USA. Shaman Pharmaceutical, 1991. 1v.

BATISTA, E. A.; COUTO, H. T. Z.; PARENTE, P. R.; TOLEDO FILHO. D. V.; BERTONI, J. E. Relações solo vegetação no desenvolvimento das espécies florestais mais importantes da Reserva Estadual de Águas da Prata, SP. Revista do Instituto Florestal, v. 8, n.2, p.167-174, 1996.

BETTOLO, R. M.; SCARPATI, M. L. Alkaloids of Croton draconides. Centinario di studio per la chimica delle sostanze organiche naturali del CNR, Rome, Italy. Phytochemistry, v. 18, n.3, p.520, 1979.

BIGHETTI, E. J.; HIRUMA-LIMA, C. A.; GRACIOSO, J. S.; BRITO, A. R. Antiinflammatory and antinoconceptive effects in rodents of the essential oil of Croton cajucara Benth. Journal of Pharmacy and Pharmacology, v.51, n.12, p.1447$1453,1999$.

BOOM, B.; DELPRETE, P. Uncaria: Plants central French Guiana. Brittonia, v.46, n.2, p.105-125, 1994. 
BORGES, J. R.; KING, S. R. Croton lechleri: sustainable utilization of an Amazonian pioneer species. Medicinal Plant Conservation, v.6, p.24-26, 2000.

BORHIDI, A.; MUÑIZ, O. Revisión del género Croton L. (Euphorbiaceae) en Cuba. Annales Historico-Naturales Musei Nationalis Hungarici, v.69, p.41-53, 1977.

BOTELHO, S. A.; DAVIDE, A. C.; FARIA, J. M. Desenvolvimento inicial de seis especies florestais nativas em dois sítios, na região sul de Minas Gerais. Cerne, v.2, n.1, p.43-52, 1996.

BRAKO, L.; ZURUCCHI, J. Catálogo de las angiospermas y gymnospermas del Perú. St. Luois-Mi: Missouri Botanical Garden. 1993. 1286p.

BRANDÃO, A T.; SANTIN, F. L. Determinação da densidade básica e confeção de pequenos objetos com a madeira de maravuyuai (Croton matourensis Aubl.) ocorrente em florestas secundárias no município de Bragança, Pará-Brasil. In: FOREST-2000, Porto Seguro, Bahia, out.-2000. Resumos FOREST-2000. Porto Seguro, Bahia-Brasil: FOREST-2000, 2000. p.41.

BRASIL Ministério de Agricultura -Instituto Brasileiro de desenvolvimento Florestal. Estatística. Anuário Brasileiro de Economia Florestal, v.18, n.18, p.121-133, 1967.

BRASIL. Ministério das Minas e Energia. Departamento Nacional de Produção Mineral. Levantamento de recursos naturais: geologia, geomorfologia, pedologia, vegetação e uso potencial da terra. RADAMBRASIL, v.12, p.464, 1976.

BRASIL. Ministério das Minas e Energia. Departamento Nacional de Produção Mineral. Levantamento de recursos naturais: geologia, geomorfologia, pedologia, vegetação e uso potencial da terra. RADAMBRASIL, v.13, p.420, 1977.

BREMER, B.; ANDREASEN, K.; OLSSON, D. Subfamilial and tribal relationships in the Rubiaceae based on RBCL sequence data. In: INTERNATIONAL CONFERENCE ON THE RUBIACEAE, 1., Annals of the Missouri Botanical Garden, v.82, n.3, p.383-397, 1995.

BREMER, K.; BREMER, B.; THULIN, E. A ordinal classification for the families of flowerin plants. Annals of The Missouri Botanical Garden, v.85, p.531-553, 1998.

BRITO, A. R.; RODRIGUEZ, J. A.; HIRUMA-LIMA, C. A.; HAUN, M.; NUÑES, D. S. Antiulcerogenic activity of trans-dehydrocrotonin from Croton cajucara. Planta Medica, v.64, n.2, p.126-129, 1998.

BRUNETON, J. Farmacognosia, fitoquímica, plantas medicinales. 2.ed. Zaragoza, Es: Acribia, 2001. 1100p. 
BUITRON, C. X. Ecuador: uso e comercio de plantas medicinales, situación actual e aspectos importantes para su conservación. Quito, Ecuador: Oficina de comercio de plantas para América del Sur TRAFFIC-Internacional, 2000. 12p (resumo executivo).

BURGER, W. Rubiaceae: Flora Costaricensis. Fieldiana, v.33, p.102-103, 1993.

CABIESES, F. La uña de gato y su entorno. 2.ed. Lima, Perú: Ed. Universidad Particular San Martín de Porres, 1997. 231p.

CAI, Y.; EVANS, F. J.; ROBERTS, M. F.; PHILlIPSON, J. D.; ZENK, M. H.; GLEBA, Y. Y. Polyphenolic compounds from Croton lechleri. Phytochemistry, v.30, n.6, p.2033-2040, 1991.

CALIXTO, V. O. Acre: uma história em construção. Rio Branco: Companhia Editora Nacional, 1974. 60p.

CAMINHA-FILHO, A. Da importância da quina e da quinina. Rio de Janeiro, Brasil: Ministério de Agricultura, 1944. 259p.

CAPASSO, A.; PIACENTE, S.; CUMANDA, J.; TOMMASI, N.; RAGUCCI, M.; PIZZA, C. Flavonol glycosides from Croton menthodorus reduce in vitro. Pharmaceutical Biology, v.36, n.5, p.310-314, 1998.

CARDOSO, M.J.N. Estudo anatômico da madeira de Chomelia obtusa Cham et Schlecht. Santa Maria-Brasil. Ciência e Natura, v. 8, p.87-94, 1986.

CARLIN, L.; VAISBERG, A. J.; HAMMOND, G. B. Isolation of sinoacutine from the leaves of Croton lechleri. Planta Medica, v.62, n.1, p.90-91, 1996.

CARVALHO, A. Viagem aos centros de origem da quineira (Cinchona sp.) (Bolivia, Peru, Equador, Colômbia) 1939-40. Campinas: IAC, 1944. 108p.

CARVAlHO, A.; KRUG, C.A. A quineira (Cinchona sp.): Origem, classificação, exploração econômica no mundo e tentativas de sua aclimatação no Brasil. Campinas: IAC, 1944. 141p.

CARVALHO, J. C.; SILVA, M. F.; MACIEL, M. A.; CUNHA-PINTO, A.; NUÑES, D. S.; LIMA, R. M.; BASTOS, J. K.; SARTI, S. J. Investigation of anti-inflammatory and antinociceptive activities of trans-dehydrocrotonin, a 19-nor-clerodane diterpene from Croton cajucara. Part 1. Planta Medica, v.62, n.5, p.402-404, 1996.

CARVALHO, P. E. R. Espécies florestais brasileiras: recomendações silviculturais, potencialidades e uso da madeira. Brasília, Brasil: EMBRAPA, 1994. 640p. 
CASAS, P. B. Prohíben en todo el país la extracción de especímenes del género Cinchona, en bosques naturales. El Peruano. Seción Normas Legales, v.1, p.171855, 1999. (R.M. N0258-99-AG).

CASTILlO-COTILlO, H. C.; SIMONE, F.; DE-FEO V. Proaporphine alkaloids from Croton ruizianus Müell.-Arg. (Euphorbiaceae). Biochemical, Systematics and Ecology, v.24, n.5, p.463-464, 1996.

CASTRO, O.; MARIA-GUTIERREZ, J.; BARRIOS, M.; CASTRO, I.; ROMERO, M.; UMANA, E. Neutralización del efecto hemorrágico inducido por veneno de Bothrops asper (Serpentes: Viperidae) por extractos de plantas tropicales. Revista de Biologia Tropical, v.47, n.3, p.605-616, 1999.

CENTRO DE DATOS PARA LA CONSERVACIÓN-CDC. Plan Director del Sistema Nacional de Unidades de Conservación (Sinuc), una aproximación desde la diversidad biológica. Lima, Pe: Universidad Nacional Agraria La Molina, 1991. $153 \mathrm{p}$.

CENTRO DOS TRABALHADORES DA AMAZÔNIA-CTA. Contribuição de manejo de uso múltiplo da floresta nacional do Macauã. Rio Branco, Acre, 1998. $138 \mathrm{p}$.

CERRI, R. New quinovic acid glycosides from Uncaria tomentosa. Journal of Natural Products, v.151, p.257-261, 1988.

CHEN, Z; CAI, Y; PHILLIPSON, J. Studies on the anti-tumour, anti-bacterial and wound-healing properties of dragon's blood. Planta Medica, v.60, p.541-545, 1994.

COIMBRA-FILHO, A. F.; MATTOS-FILHO, M. Ensaio e apontamento sôbre a urucurana (Hieronyma alchorneoides Fr. All.). Anuário Brasileiro de Economia Florestal, v.6, n.6, p.3-10, 1955.

COIMBRA, R. Manual de Fitoterapia. 2.ed. Belém: Cejup, 1994. 1v.

COMISSÃO PAN-AMERICANA DE NORMAS TÉCNICAS-COPANT. Descrição macroscópica, microscópica e geral da madeira. São Paulo. COPANT, v.30, p.1-19, 1974. (Esquema 1).

CRAVEIRO, A. A.; SILVEIRA, E. R. Two cleistanthane type diterpenes from Croton sonderianus. Phytochemistry, v.21, n.10, p.2571-2574, 1982.

CRONQUIST, A. The evolution and classification of flowering plants. 2.ed. New York: The New York Botanical Garden Press, 1988. 555 p. 
CRUZ, G. L. Dicionário das plantas úteis do Brasil. 5.ed. Rio de Janeiro: Editora Bertrand, 1995. 1v.

DAVIDE, A.C.; BOTELHO, S. A.; FARIA, J. M.; PRADO, N. J. Comportamento de espécies florestais de mata ciliar em área de depressão do reservatório da usina hidrelétrica de Camargos, Itutinga, MG, Brasil. Cerne, v.2, n.1, p.20-34, 1996.

DAVIS, D.E. The annual cycle of plants, mosquitoes, birds and mammals in two Brazilian forests. Ecological Monographs, v.15, p.243-295, 1945.

DECANDOLLE. A description of the Genus Cinchona. London: British Museum. (1797) 1830. 4144p.

DESMARCHELIER, C.; MONGELLI, E.; COUSSIO, J.; CICCIA, G. Evaluation of the in vitro antioxidant activity in extracts of Uncaria tomentosa. Phytother Research, v. 11, p.254-256, 1997.

DELPRETE, P.G.; CORTÉS, R. Rubiaceae del Nuevo Mundo. In: CONGRESO LATINOAMERICANO DE BOTÁNICA, 8., Cartagena de Indias, Co, 2002 Resúmenes del VIII-CLB. Santafé de Bogotá, Co: ALB/ACB/ACH/ICN, 2002. p.417.

DÉTIENNE, P.; JACQUET, P. Atlas d'identification des bois de l'amazonie et des régions voisnes. Montpellier, Fr: Centre Technique Forestier Tropical, 1983. 640p.

DINNERTEIN, E.; OLSON, D. M.; GRAHAN, D. J.; WEBSTER, A. L.; PRIMM, S. A.; BOOKBINDER, M. P.; LEDEC, G. A conservation assessment of the terrestrial ecoregions of Latin America and the Caribbean Report. Washington, EUA: WWF, The World Bank, 1995. 129p.

DOMÍNGUEZ-TORREJÓN, G. Uña de gato y producción sostenible. Lima, Pe: Universidad Nacional Agraria La Molina, 1997. 138p.

DUKE, J.; VASQUEZ, R. Amazonian ethnobotanical dictionary. Florida, EUA: CRC Press, 1994. 1v.

EMPRESA BRASILEIRA DE PESQUISAS AGROPECUÁRIA-EMBRAPA. Sistema Brasileiro de Classificação de Solos. Rio de Janeiro: EMBRAPA, 1999. 412p.

EVANS, S. R. El floklore botánico y la conservación de los recursos naturales. Lima, Pe: Fundación Peruana Para la Conservación de la Naturaleza, 1989. 1v. (Documento de Conservación, 4). 
FARIA, R. A.; RAO, V. S.; VIANA, G. S.; SILVEIRA, E. R.; MACIEL, M. A.; PINTO, A. C. Hypoglycemic effect of trans-dehydrocrotonin, a nor-clerodane diterpene from Croton cajucara. Planta Medica, v.63, n.6, p.558-560, 1997.

FEDALTO, L.C.; MENDEZ, I.C.A.; CORADIN, V.T. Madeiras da Amazônia lenho de 40 espécies ocorrentes na Floresta Nacional do Tapajos. Belém, Pará: IBAMA, 1989. 156p.

FERRAZ, D. K.; ARTES, R.; MANTOVANI, W.; MAGALHÃES, L. M. Fenologia de árvores em fragmento de mata em São Paulo, SP. Revista Brasileira de Biologia, v.59, n.2, p.305-317, 1999.

FIELD, F.; BORN, E.; MANTHUR, S. Effect of micellar beta-sitosterol on cholesterol metabolism in CaCo 2 cells. Journal of Lipid Research, v.38, p.348-360, 1997.

FLORSHEIM, B.S.M.; ROCHA, T.F. Anatomia de essências Florestais da Reserva Estadual da Cantareira-São Paulo. In: ENCONTRO BRASILEIRO EM MADEIRAS E ESTRUTURAS DE MADEIRAS, São Carlos, SP, 1987. Anais. São Paulo, 1987. p.1-39.

FLORES-BENDEZU, Y. Manual para la producción de plantones de "uña de gato. Pucallpa, Pe: Instituto Nacional de Investigación Agraria, 1995a. 4p.

FLORES-BENDEZU, Y. Propagación por semillas de la "Uña de Gato". PucallpaPe:. Instituto Nacional de Investigación Agraria, 1995b. 51p. (Boletín Técnico 5).

FORERO, E.; CHÁVEZ, R.; BERNAL, H. Y. Agrotecnología para el cultivo de sangre de grado o sangregrado. In: MARTÍNEZ J. V.; BERNAL, H. J.; CÁCERES, A. Fundamentos de agrotecnología para el cultivo de plantas medicinais Iberoamericanas. Santafé de Bogotá, Co: Convenio Andrés Bello, Ciencia y Tecnología para el Desarrollo, 2000. p157-190.

FOSTER, B. I.; BRILHANTE, B. H.; MENDOZA, E.; RIBEIRO, O. I. de. Estrada de Rio Branco, AC. aos portos do Pacífico: Como maximizar os benefícios e minimizar os prejuízos para o desenvolvimento sustentável da Amazônia Sul-Ocidental. LimaPe. In: ENCUENTRO INTERNACIONAL DE INTEGRACION REGIONAL BOLIVIA, BRASIL Y PERÚ. Arequipa Perú, 2-4 de Set.-2001. Resumenes del encuentro Río Branco. Lima, Perú: Editora CEPEI, 2002. p.1-8.

FRANSSEN, F.F.J.; SMEIJSTERS, L.J.J.W.; BERGER, I.; MEDINILLA-ALDANA, B.E. In vivo and in vitro antiplasmodial activities of some plants traditionally used in Guatemala against malaria. Antimicrobial Agents and Chemotherapy, v.41, n.7, p.1500-1503, 1997. 
FREITAS, A. J. de; VASCONCELLOS, F.J. de; SILVA B. N. da; LAUREIRO, A.A. Madeiras da Amazônia que apresentam raios largos. Acta Amazônica n.22, n.1, p.91-161, 1992.

FUNDAÇÃO DE TECNOLOGIA DO ESTADO DO ACRE-FUNTAC. Atlas educativo do Estado do Acre. Rio Branco, AC: Governo do Estado do Acre, 1990. $48 \mathrm{p}$.

FUNDAÇÃO DE TECNOLOGIA DO ESTADO DO ACRE-FUNTAC. Diagnóstico do setor florestal do Estado do Acre: monitoramento da cobertura florestal do Estado do Acre e desmatamento e uso atual da terra. Rio Branco, AC: FUNTAC, 1991. 180 p.

FUNDAÇÃO NACIONAL DE SAÚDE-FUNASA. Relatório de dados populacionais. Rio Branco, AC: FUNASA, 1999. 1v.

GARCIA-BARRIGA, H. Flora medicinal de Colombia: Botánica Médica. Bogotá de Santafé, Co: Talleres Editoriales de la Imprenta Nacional, 1975. 1v.

GASPAR, J.W.; GUEDES, R.L. Caracterização anatômica de Genipa americana L. In: CONGRESSO NACIONAL DE BOTÂNICA, 49., Salvador- Bahia, 1998. Resumo. Salvador, Bahia: Sociedade Botânica do Brasil. 1998. p17.

GENTRY A A fied guide to the families and genera of woody plants of northwest Southamerica. Washington DC.: Conservation Internacional, 1993. 411p.

GENTRY, A.H.; FORSYTH, A.G. A field guide to the families and genera of woody plants of northwest South America: Colombia, Ecuador, Peru. Washington DC.: Conservation International, 1998. 1v. (Notas Complementares).

GIULIETTI, A.; FORERO, E. Diversidade taxonômica e padrões de distribuição das angiospermas brasileiras-Introdução. Acta Botânica Brasílica, v.4, n.1, p.3-10, 1990.

GONÇALVES, J. L.; GONÇALVES, J. C.; OLIVEIRA, D. B.; SIMIONATO, J. L.A.; GANDARA, F.; CENCI, S. Croton urucurana, the pioneer and secondary species responded best to the applied treatments. Revista Árvore, v.23, n.3, p.259-270, 1999.

GOtTIEB, H. E.; GOTTIEB, O. R.; MAGAlHÃES, M. T.; DASILVA, V. O. Diasin, a diterpene from Croton diasii. Phytochemistry, v.17, n.10, p.1773-1776, 1978. 
GRYNBERG, N. F.; ECHEVARRIA, A.; LIMA, J. E.; PAMPLONA, S. S.; PINTO, A. C.; MACIEL, M. A. Ant i-tumour activity of two 19-nor-clerodane diterpenes, transdehydrocrotonin and trans-crotonin, from Croton cajucara. Planta Medica, v.65, n.8, p.687-689, 1999.

GUDIÑO, E.; GUTIERREZ. F.; ESPINOZA, F. Lineamientos preliminares para el manejo de Croton sp. en la Amazonía Ecuatoriana. Quito, Equador: Shaman Farmaceticals, 1991. 21p.

GUPTA, M. F. Plantas medicinais iberoaméricas. Santafé de Bogotá, Co: Editorial Presencia, 1995. p.486-487.

HARADA, M.; OZAKI, Y.; SATO, M. Ganglion blocking effect of indole alkaloids contained in Uncaria genus and Amsonia genus and related synthetic compounds on the rat superior cervical ganglion in situ. Tokyo Chemical \& Pharmaceutical Bulletin, v.22, p.1372-1377, 1974.

HARDESTY, L. H.; BOX, T. W. Defoliation impacts on coppicing browse species in northeast Brazil. Journal of Range Management, v.41, n.1, p.66-70, 1988.

HARDESTY, L. H.; BOX, T. W.; MALECHEK, J. C. Season of cutting affects biomass production by coppicing browse species of the Brazilian caatinga. Journal of Range Management, v.41, n.6, p.477-480, 1988.

HAVILAND, G. D. A Revision of Naucleeae (Nat. Ord. Rubiaceae). Botanical Journal of the Linnean Society, v.33, n.1, p.31-33, 1898.

HEMINGWAY, S.; PHILLIPSON, J. N-oxides isolated during the alkaloid screening of Uncaria species. Journal of Pharmacy and Pharmacology, v.1, p.169-170, 1992.

HIRUMA-LIMA, C. A.; GRACIOSO, J. S.; RODRIGUEZ, J. A.; HAUN, M.; NUÑES, D. S.; SOUZA-BRITO, A. R. Gastroprotective effect of essential oil from Croton cajucara Benth. (Euphorbiaceae). Journal of Ethnopharmacology, v.69, n.3, p.229-234, 2000.

HIRUMA, C. A.; SPADARI, R. C.; GRASSI K.; SOUZA-BRITO, A. R. Antiulcerogenic mechanisms of dehydrocrotonin, a diterpene lactone obtained from Croton cajucara. Planta Medica, v.65, n.4, p.325-330, 1999.

HODGE, H. W. Wartime, Cinchona procurement in Latin America. Economic Botany, v.2, p.229-257, 1948.

HUANG, K. C. The pharmacology of Chinese herbs . Florida: Hardcover book press, 1999. 512p. 
HUTCHINSON, J. The genera of flowering plants-Angiospermae: dicotyledones. Oxford, United Kingdow: Oxford University Press, 1964-1967. 2v

IAWA Committee. 1989. IAWA list of microscopic feature for hardwood identification. IAWA Bulletin, v.10, n.3, p.219-332, 1989.

ICHIHARA, Y.; TAKEYA, K.; HITOTSUYANAGI, Y.; MORITA, H.; OKUYAMA, S.; SUGANUMA, M.; FUJIKI, H.; MOTIDOME, M.; ITOKAWA, $\mathrm{H}$. Cajucarinolide and isocajucarinolide: anti-inflammatory diterpenes from Croton cajucara. Planta Medica, v.58, n.6, p.549-551, 1992.

INSTITUTO BRASILEIRO DE GEOGRAFIA E ESTATISTICA-IBGE. Anuário Estatístico do Brasil-1995. Rio de Janeiro: IBGE, 1995. 1v.

INSTITUTO BRASILEIRO DO MEIO AMBIENTE E DOS RECURSOS NATURAIS RENOVÁVEIS-IBAMA. Normas e procedimentos em estudos de anatomia da madeira: Angiosperme e Gimnospermae. Brasília, Go: Diretoria de Incentivo à Pesquisa e Divulgação, 1992. 17p. (Séria Técnica, 15).

INSTITUTO DO MEIO AMBIENTE DO ACRE-IMAC. Atlas geográfico ambiental do Acre. Rio Branco, Acre-Brasil: Secretaria de Meio Ambiente do Acre, 1991. 1v.

INSTITUTO DO MEIO AMBIENTE DO ACRE-IMAC. Zoneamento Ecológico Econômico-ZEE. Rio Branco, Acre-Brasil: SEPLAN/SECTMA, 2000. 3v.

INSTITUTO NACIONAL DE PESQUISAS AEROESPACIAIS-INPE. Monitoramento da floresta Amazônica Brasileira por satélite, maio 2000. São José dos Campos, SP-Brasil. INPE, 2000. lv.

INSTITUTO PERUANO DE SEGURIDAD SOCIAL-IPSS. Plantas medicinales de la Amazonía Peruana. Iquitos-Peru: INMETRA, 1997. p.226-229.

ITOKAWA, H.; ICHIHARA, Y.; TAKEYA, K.; MORITA, H.; MOTIDOME, M. Diterpenes from Croton salutaris. Phytochemistry, v.30, n.12, p.4071-4073, 1991.

INTERNATIONAL UNION FOR CONSERVATION OF NATURE-IUCN. The IUCN Red List of Threatened Plants. Gland, Switzerland: IUCN, 1998. 1v.

INTERNATIONAL UNION FOR CONSERVATION OF NATURE-IUCN. The IUCN Red List of Threatened Plants. Version 3.1. Gland. Switzerland: IUCN, 2002. 1v. (Species Survival Commission).

JANSEN, S.; ROBBRECHT, H. E.; BECKMAN, H.; SMETS, E. A survey of the systematic wood anatomy of the Rubiaceae. IAWA Journal, v.23, n.1, p.1-68, 2002. 
JOHANSEN, D. A. Plant microtechnique. New York: MacGraw-Hill Book. 1940. $533 p$

JONG, W.; MELNYK, M.; LOZANO, L. A.; ROSALES, M.; GARCIA, M Uña de gato: fate and future of a Peruvian forest resource. Jacarta, Indonesia: CIFOR, 1999. 17p. (Occasional-Paper, 22).

KAHN, F.; FERREIRA, E.J.L. A new species of Astrocaryum (Palmae), from Acre, Brazil. Candolle, v. 50, p.321-328, 1995.

KAM, T.; LEE, K.; GOH, S. Alkaloid distribution in Malaysian Uncaria. Phytochemistry, v.31, p.2031-2034, 1992.

KEEBLE, T.W. A cure for the ague: the contribution of Robert Talbor (1642-81). Journal of the Royal Society of Medicine, v.90, n.5, p.285-290, 1997.

KEPLINGER, K. Cytostatic, contraceptive and antiinflammatory agent from Uncaria tomentosa roots. Massachusetts: Longwood Herbal Task Force, 1982. p.27. (U.S. Patent N., 4,844,901).

KEPLINGER, K.; LAUS, G.; WURM, M.; DIERICH, M.P.; TEPPNER, H. Uncaria tomentosa (Willd.) DC. Ethnomedicinal use and new pharmacological, toxicological and botanical results. Journal of Ethnopharmacology, v.64, p.23-34, 1999.

KIRMSE, R. D.; PROVENZA, F. D.; MALECHEK, J. C. Clearcutting Brazilian caatinga: assessment of a traditional forest grazing management practice. Agroforestry Systems, v. 5, n.4, p.429-441, 1987.

KOHN, E. La cultura médica de los Runas de la Amazónica Ecuatoriana. Hombre y Ambiente, v.21, p.1-143, 1992.

KUBO, I.; ASAKA, Y.; SHIBATA, K. Insect growth inhibitory nor-diterpenes, cis dehydrocrotonin and trans-dehydrocrotonin, from Croton cajucara. Phytochemistry, v.30, n.8, p.2545-2546, 1991.

LAHLOU, S.; LEAL-CARDOSO, J. H.; CALDAS, M. P. Cardiovascular effects of the essential oil of Croton nepetaefolius in rats: role of the autonomic nervous system. Planta medica, v.65, n.6, p.553-613, 1999.

LAUS, G.; BROSSNER, D.; KEPLINGER, K. Alkaloids of Peruvian Uncaria tomentosa. Phytochemistry, v.45, p.855-860, 1997.

LEMOS, T. L.; MONTES, F. J.; MATOS, F. J.; ALENCAR, J. W.; CRAVEIRO, A. A.; BARBOSA, R. C.; LIMA, E. O. Chemical composition and antimicrobial activity of essential oils from Brazilian plants. Fitoterapia, v.63, n.3, p.266-268, 1992. 
LESCURE,J.; PINTON, P.; EMPERIRE, L. People and forest products in central Amazonia: The multidisciplinary approach of extractivism. Paris, França: UNESCO, 1987. p.58-89, pt-18.

LIMA, R. L. de; PIRANI, J.R. O gênero Croton L. (Euphorbiaceae) na Cadeia do Espinhaço, Minas Gerais, Brasil. Boletim Botânica Universidade de São Paulo, v.21, n.2, p.299-344, 2003.

LOCK-DE-UGAZ, O. Investigación Fitoquímica: Uncaria tomentosa y U. guianensis. Lima, Pe: Fondo Editorial, Pontificia Universidad Católica del Perú, 1994. 300p.

LOMBARDI, I.; ZEVALLOS, P. A. Guía para el cultivo, aprovechamiento y conservación de la uña de gato (Uncaria tomentosa). Santafé de Bogotá, Co: Editorial Gente Nueva, 1999. 47p.

LORENZI, H. Árvores brasileiras: Manual de Identificação e cultivo de plantas arbóreas nativas do Brasil. São Paulo: Editora Plantarum, 1992. 352p.

LOURERO, A. A. Contribuição ao estudo anatômico de Croton lanjouwensis (Müll.Arg.) Jablonski e C. matourensis Aublet (Euphorbiaceae). Rio de Janeiro: Instituto Nacional de Pesquisas da Amazônia-INPA/CNPq., 1968. 24p. (Publicação, 24)

MACBRIDE, F. Flora of Peru. Field Museum of Natural History Chicago, v.13, p.1112, 1936. (Botanical Series).

MACIEL, M. A. M.; PINTO, A. C.; BRABO, S. N.; SILVA, M. N. da. Terpenoids from Croton cajucara. Phytochemistry, v.49, n.3, p.823-828, 1998.

MACIEL, M. A.; PINTO, A. C.; ARRUDA, A. C.; PAMPLONA, S. G.; VANDERLINDE, F. A.; LAPA, A. J.; ECHEVARRIA, A.; GRYNBERG, N. F.; COLUS, I. M.; FARIAS, R. A.; COSTA, A. M.; RAO, V. S. Ethnopharmacology, phytochemistry and pharmacology: a successful combination in the study of Croton cajucara. Journal of Ethnopharmacology, v.70, n.1, p.41-55, 2000.

MAHMOOD, N.; PIZZA, C.; AQUINO, R.; TOMMASI, N.; PIACENTE, S.; COLMAN, S.; BURKE, A.; HAY, A. J. Inhibition of HIV infection by flavanoids. Antiviral Research, v.22 n.2/3, p.189-199, 1993.

MAINIERI, C.; Madeiras denominadas caixetas. São Paulo: IPT, 1958. 97p. (Publicação, 572). 
MAINIERI, C. Estudo macro e microscópico de madeiras conhecidas por paut brasil. IPT. São Paulo: IPT, 1960. 62p. (Publicação, 612).

MAINIERI, C. Madeiras leves da Amazônia empregadas como caixotaria: Estudo anatômico macro e microscópico. São Paulo: IPT, 1962. p.13-14. (Publicação, 686).

MAINIERI, C. Fichas de características das madeiras brasilieras. São Paulo: IPT, 1978. 418p. (Publicação, 966).

MAINIERI, C.; PEREIRA, J.A. Madeiras do Brasil. São Paulo: IPT, 1965. 416p. (Publicação, 16).

MAINIERI, C.; CHIMELO, J.P. Fichas de características das madeiras brasileiras. 2. ed. São Paulo: IPT, 1989. 418p. (Publicação, 1791).

MÁLAGA, G. Efecto del chorhidrato de taspina sobre la curación del úlcera gástrica inducida en ratas. Lima, Perú, 1991. 134p. Tesis (Graduación), Facultad de Ciencias Biológicas, Universidade Nacional Mayor de San Marcos.

MARIANO, G.; CRESTANA, C. S.; BATISTA, E. A.; GIANNOTTI, E.; COUTO, H.T. Regeneração natural em área a margem de represa, no município de Piracicaba, São Paulo-Brasil. Revista do Instituto Florestal, v.10, n.1, p.81-93, 1998.

MARTINS, A. P.; SALGUEIRO, L. R.; GONÇALVES, M. J.; VILA, R.; TOMI, F.; ADZET, T.; PROENÇA-DA-CUNHA, A.; CANIGUERAL, S.; CASANOVA, J. Antimicrobial activity and chemical composition of the bark oil of Croton stellulifer, na endemic species from S. Tome e Principe. Planta Medica, v.66, n.7, p.647-650, 2000.

MATTA, S. de; MONARCHE, F.; FERRARI, F.; MARINI-BETTOL, G. Alkaloids and procyanidins of an Uncaria spp from Peru. Farmaco, v.31, p.527-535, 1976.

MELO, C. F. M.; HUNH, S. Polpas branqueadas de madeiras da Amazônia, Belém, Pará-Brasil. Boletim Técnico IPEAN, v.61, p.1-23, 1974.

MELO, M. E.; ALENCAR S. J; ALVES, P. R. Subsídios técnicos para o manejo sustentável da unha-de-gato (Uncaria spp.) no vale do Rio Juruá, Acre. Rio Branco: EMBRAPA-AC, 2001. 20p. (Documento, 68).

MENDOÇA, R. C.; FELFILI, J. M.; WALTER, B. M.; SILVA-JUNIOR, M. C.; REZENTE, A.V.; FILGUEIRA, T. S.; SILVA, P. E. Flora vascular do cerrado. In: SANO, S.M.; ALMEIDA, S.P. Cerrado: Ambiente e Flora. Brasília, GO: EMBRAPA-CPAC, 1998. p.289-556. 
MENEZES, M. A. As reservas extrativistas como alternativa do desmatamento na Amazônia. In: ARNT R. O destino da floresta-reservas extrativistas e desenvolvimento sustentável na Amazônia. Rio de Janeiro: Relume Dumará, 1994. p.49-72.

MESSIAS, R. El desafio ambiental em América latina. s.1.: AMBIENTEC, 2001. 1v.

METZGER, J. P.; BERNACCI, L. C.; GOLDENBER, R. Pattern of tree species diversity in riparian forest fragments of different widths, Sergipe, Brazil. Plant Ecology, v.133, n.2, p.135-152, 1997.

METZGER, J.P.; GOLDENBERG, R.; BERNACCI, L.C. Diversidade e estrutura de fragmentos de mata de várzea e de mata mesófila semidecídua submontana do rio Jacaré-Pepira. São Paulo-Brasil. Revista Brasileira de Botânica, v.21, n.3, p.321330, 1998.

MEZA, E.; AYALA F. El manejo sostenible de sangre de drago o sangre de grado. San Francisco: Shaman Pharmaceuticals \& Healing Consevancy, 1998. 29p. (Material Educativo).

MEZA, E. N.; PARIONA, M. Nombres aborígenes peruanos de las especies de Croton que producen el látex denominado sangre de grado. Lima, Pe: Fondo Editorial Universidad Nacional Mayor de San Marcos, 1999a. 44p.

MEZA, E. N. Cosecha de sangre de grado y factores que influyen en su abundancia, desarrollando nuestra diversidad biocultural: sangre de drago y el reto de su producción sustentable en el Perú. Lima, Pe: Gráficos, 1999b. 76p.

MILLER, M. J.; MAC'NAUGHTON, W. K.; ZHANG, X. J.; THOMPSON, J. H.; CHARBONNET, R. M.; BOBROWSKI, P.; LAO, J.; TRENTACOSTI, A. M. Treatment of gastric ulcers and diarrhea with the Amazonian herbal medicine sangre de grado. American Journal of Physiology, v.279, n.1, p.192-200, 2000.

MITTERMEIER, R. A.; ROBLES, G. P.; MITTERMEIER, C. G. Megadiversidad: los países biologicamente más ricos del mundo. México: CEMEX, 1997. 501p.

MORAES, M. O.; FONTELES, M. C.; MORAES, M. E.; MACHADO, M. I.; MATOS, F. J. Screening for anticancer activity of plants from the Northeast of Brazil. Fitoterapia, v.68, n.3, p.235-239, 1997.

MORAES-NETO, S. P. de; GONÇALVES, J. L. de; TAKAKI, M.; CENCI, S.; GONÇALVES, J. C. Crescimento de mudas de algumas espécies arbóreas que ocorrem na mata atlântica, em função do nível de luminosidade. Revista Árvore, v.24, n.1, p.35-45, 2000. 
MORELLATO, L.P.; LEITÃO-FILHO, H, de F. Estratégias fenológicas de espécies arbóreas em floresta mesófila na Serra do Japi, Jundiaí, São Paulo. Revista Brasileira de Biologia, v.50, n.1, p.163-173, 1990.

MOSS, R. Cat's Claw: new treatment from Amazon. In: The cancer chronicles, 1998. Journal Altern Complement Medic, v.5, p.143-151, 1999.

MÜELLER, J. Croton. Flora Brasiliensis. Von Martius, v.11, n.2, p.81-274, 1873.

MUSTALISH, R. W.; EVANS, B.; TUCKER, C.; KLEIN, K.; CRAKER, L. E.; NOLAN, L.; SHETTY, K. Development of a phytohabitat index for medicinal plants in the peruvian Amazon. In: INTERNATIONAL SYMPOSIUM ON MEDICAL AND AROMATIC PLANTS. Amherst, Massachusetts, ago. 27-30, 1995. Acta Horticulturae, v.26, p.123-131, 1996.

NAGAMOTO, N. Effect of micellar beta-sitosterol on cholesterol metabolism in CaCo2 cells. Planta Medica, v.43, p.305-307, 1988.

NASCIMENTO, H. E.; DIAS, A.D; TABANEZ, A. A.; VIANA, V. M. Estrutura e dinâmica de populações arbóreas de um fragmento de floresta estacional semidecidual na região de Piracicaba, São Paulo-Brasil. Revista Brasileira de Biologia, v.59, n.2, p.329-342, 1999.

NEILL, D. El uso de sangre de drago Croton leichleri. In: REUNIÃO HERBÁRIO GEORGE MARGGRAF, Río de Janeiro-Brasil, 1986. Anais. Rio de Janeiro: Ministerio de Cultura-Fundacão Nacional Pró-Memória, 1986. p.11-34.

OBREGON, L.E. "Uña de gato", género Uncaria: estudios botánicos, químicos e farmacológicos de Uncaria tomentosa e Uncaria guianensis. Lima, Pe: Instituto de Fitoterapia Americano, 1995. 169p.

OCAMPO-SANCHEZ, R. A. Agrotecnología para el cultivo de quina o cascarilla. In: MARTÍNEZ J. V.; BERNAL, H. J.; CÁCERES, A. Fundamentos de agrotecnología para el cultivo de plantas medicinais Iberoamericanas. Santafé de Bogotá, Co: Convenio Andrés Bello/Ciencia y Tecnología para el Desarrollo, 2000. p.147-156.

OLIVEIRA, M. E ; SAMPAIO, E. V.; CASTRO, A. A.; RODAL, M. J. Flora e fitossociologia de uma área de transição carrasco-caatinga de areia em Padre Marcos, Piaui, Brasil. Naturalia, v. 22, p.131-150, 1997.

ORTEGA, T.; CARRETERO, M. E.; PASCUAL, E.; VILLAR, A. M.; CHIRIBOGA, X.; CAPASSO, F; EVANS, F.; .J; MASCOLO, N. Anti inflammatory activity of ethanolic extracts of plants used in traditional medicine in Ecuador. Phytotherapy Research. Suppl 1, v.10, p.121-122, 1996. 
PAGANO, S. N. Nutrientes minerais do folhedo produzido em mata mesófila semidecídua no município de Rio Claro, São Paulo, Brasil. Revista Brasileira de Biologia, v.49, n.3, p.641-647, 1989.

PALLAR-DE-PERALTA, T. Plantas útiles para emergencias y primeros auxilios. In: CONGRESO INTERNACIONAL DE MEDICINAS TRADICIONALES, 2., Lima, Pe, 1988. Resumenes, Área de Farmacognosia. Lima, Pe: Instituto de Fitoterapia Americano, 1988. p.29-50.

PASSOS, L.; FERREIRA, S. O. Ant dispersal of Croton priscus (Euphorbiaceae) seeds in a tropical semideciduous forest in southeastern Brazil. Biotropica, v.28, n.4, p.697-700, 1996.

PEÑA, C. R.; TIMMERMANN, T. B; ITURRIAGA, L.; GONGÁLEZ, L.; MONTENEGRO, G. Posibilidades de un control botánico analítico de uña de gato Uncaria tomentosa (Willd.) DC. Revista de la Académia Colombiana de Ciencias Exactas, Físicas y Naturales, v.22, p.595-600, 1998.

PERDUE, G. P.; BLOMSTER, R. N.; BLAKE, D. A.; FARNSWORTH, N. R. South american plants II: Taspine isolation and anti-inflammatory activity. Journal of Pharmaceutical Sciences, v.68, n.1, p.124-126, 1979.

PEREIRA, A. S.; AMARAL, A. C. F.; BARNES, R. A.; CARDOSO, J. N.; AQUINONETO F.R. Identification of isoquinoline alkaloids in crude extracts by high temperature gas chromatography-mass spectrometry. Phytochemical Analysis, v.10, n.5, p.254-258, 1999.

PERES, M. T.; DELLE-MONACHE, F.; CRUZ, A. B.; PIZZOLATTI, M. G.; YUNES, R. A. Chemical composition and antimicrobial activity of Croton urucurana Baillon (Euphorbiaceae). Journal of Ethnopharmacology, v.56, n.3, p.223-226, 1997.

PERES, M. T.; DELlE-MONACHE, F.; IZZOLATTI, M. G.; SANTOS, A. R.; BEIRITH, A.; CALIXTO, J. B.; YUNES, R. A. Analgesic compounds of Croton urucurana Baillon. Phytotherapy Research, v.12, n.3, p.209-211, 1998.

PÉREZ, E. Estudios de 4 plantas de la zona del Huallaga con actividad cicatrizante. In: CONGRESO INTERNACIONAL DE MEDICINAS TRADICIONALES, 2., Lima, Pe, 1988. Resumenes, Área de Farmacognosia. Lima, Pe: Instituto de Fitoterapia Americano, 1988. p.3-7.

PEREZ-OLIVERA, C.; CARMONA, V. T. F.; ROGEL, G. M. Estudio anatômico de la madera de 43 especies tropicales. México, DC: Instituto Nacional de Investigaciones Forestales. 1980. 276p. (Boletín Técnico, 03). 
PERSINO-PUEDUE, G. Antiiflammation compositions containing taspine or acid salt their of and method of use. Massachusetts: Longwood Herbal Task Force, 1980. 1v. (U.S. Patent N., 3,694,557).

PERSINO-PURDUE, G.; BLOMSTER, R. M.; BLAKE, D. A.; FARNSWORTH, N. R. South American Plants II: taspine isolation and anti-inflammatory activity. Journal of Pharmacology Science, v.68, n.1, p.124-126, 1979.

PHILIP, K. Imperial science rescues a tree: global botanic networks, local knowledge and the transcontinental transplantation of Cinchona. Environment and History, v.1. n.2, p.173-200, 1995.

PIETERS, L. A.; VLIETINCK, A. J.; BERGHE, D. A. Biologically active constituents of sangre de drago, a traditional south american drug. Planta Medica, v.56, n.6, p.386-391, 1990.

PIETERS, L A.; DE-BRUYNE, T. In vivo wound healing activity the drago`s blood (Croton spp). A Tradicional Americans Drug and Constituents Phytomedicine, v.2, n.1, p.12-22, 1995.

PIMENTEL, M.M.; VANNUCCI, L. L. Lista vermelha das espécies ameaçadas de extinção da flora de Minas Gerais. Belo Horizonte, MG: Fundação Bidiversitas e Fundação Zoo-Botânica de Belo Horizonte, 2000. 160p.

PINEDO, P. M.; RENGIFO, E.; CERRUTI, T. Plantas medicinais de la Amazonía peruana, estudos de usos y cultivos. Lima, Pe: Tratado de Cooperación Amazónica, 1997. 210p.

PITMAN, N. A.; JORGESEN, P. M. Estimating the size of the world's threatened flora. Science, v.298, p.989, 2002.

PRANCE, G.T. Floristic inventory of the tropics: where do we stand? Annals of the Missouri Botanical Garden, v.64, p.559-684, 1977.

PRIMO, B.L. Tannin content of some brazilian plant products. Associação Brasileira de Química, v.4, p.117-120, 1945.

PRINZ, A. Discovery of the cardiac effectiveness of cinchona bark and its alkaloids. Wien Klin Wochenschr, v.102, n.24, p.721-723, 1990.

PROGRAMA DAS NAÇÕES UNIDAS PARA O MEIO AMBIENTE-PNUMA. GEO: Global Environment Outlook 3: Past, present and future perspectives 2002. New York: The United Nations Environment Programme, 2002. 426p. 
QUEVEDO, G. A. Silvilcultura y manejo de la "uña de gato". Pucallpa, Pe: Instituto de Investigaciones de la Amazonia Peruana-IIAP, 1995. 43p.

RADFORD, A. E.; WILLLIAM, C.; DICKINSON, J.; MASSEY, R.; RITCHIE, B. C. Vascular plant systematics. New York: Harper and Row, 1974. 891p.

RAMIREZ, E. "Uña de gato" Curso de introducción a la etnobotánica. Lima, Pe: Facultad de Ciencias y Filosofía, Universidad Peruana Cayetano Heredia, 1992. 10p.

REA, R. L. Cinchona y la tribu Cinchonaeae (Rubiaceae) en Bolivia, actualización sistemática, fitoquímica y actividad antimalárica. La Paz Bolívia, 1995. 183p. Tese (Graduação), Universidade Mayor de San Andrés de La Paz-Bolívia.

REINHARD, K. H. Uncaria tomentosa (Willd.) D.C.: cat's claw, una de gato, or saventaro. Journal Altern Complement Medic, v.5, p.143-151, 1999.

RIBEIRO, J.F.; WALTER, B.M,T. Fitofisionomia do bioma cerrado. In: SANO, S.M.; ALMEIDA, S.P. Cerrado: Ambiente e Flora. Brasília, GO: EMBRAPA-CPAC, 1998. p.89-166.

RIDSDALE, C.E A revision of Mitragyna and Uncaria (Rubiaceae). Blumea, v.24, p.43-100, 1972.

RIINA, R.; BERRY, P.. Abordando un gigante taxonómico: filogenia y florística del género Croton (Euphorbiaceae). In: CONGRESO LATINOAMERICANO DE BOTANICA, 8., Cartagena de Indias, Co, 2002. Resúmenes del VIII-CLB. Santafé de Bogotá, Co: ALB/ACB/ACH/ICN, 2002. p.430.

ROBBRECHT, E. Tropical woody Rubiaceae. Opera Botanica Belga. v.1, p.1-271, 1988.

ROGEL-GOMEZ, M.A. Características anatômicas de la madera de siete especies tropicales. México, DC.: Instituto Nacional de Investigaciones Forestales, 1982. 55p. (Boletín técnico, 86).

SAMPAIO, E. V.; SALCEDO, I. H.; KAUFFMANN, J. B. Effect of different fire severities on coppicing of caatinga vegetation in Serra Talhada, Pernanbuco, Brazil. Biotropica, v.25, n.4, p.452-460, 1993.

SAMPAIO, E. V.; ARAUJO, E. L.; SALCEDO, I. H.; TIESSEN, H. Regeneração da vegetacão da caatinga após corte e queima, em Serra Talhada, Pernambuco. Pesquisa Agropecuária Brasileira, v.33, n.5, p.621-632, 1998. 
SANTINI, F.; BRANDÃO, A.; OLIVEIRA, W. Caracterização tecnológica da madeira de maravuvuia (Croton matourensis Aublet) ocorrente em florestas secundárias no município de Bragança, Pará, com vistas a definição de usos: resultados preliminares. In: CONGRESSO INTERNACIONAL DE COMPENSADO E MADEIRA TROPICAL, Belém, Pará-Brasil, 1999. Resumos do Congresso. Belém do Pará: CIMT, 1999. 72p.

SANTOS, M. A.; ELISABETSKY, E. Etnofarmacologia como ferramenta na seleção de espécies de plantas medicinais para triagem de atividade antitumoral. Revista Brasileira de Plantas Medicinais, v.2, n.1, p.7-17, 1999.

SASS, J. E. Botanical microtechnique. 2 ed. State College Press, Iowa. 1951. 228 p.

SCHACHT, W.H.; MALECHEK , J.C. Botanical composition of goat diets in thinned and cleared deciduous woodland in northeastern Brazil. Journal of Range Management, v.43, n.6, p.523-529, 1990.

SCHEUCH, R. H. S.; HIDALGO-LOZANO, V. Efecto del tratamiento alcalino sobre la digestibilidad de maderas de bosques secundarios de Pucallpa. Lima-Peru. Revista Forestal del Perú, v.20, n.1, p.75-86, 1993.

SCHMITT, L. Tratamiento antitumoral con plantas medicinales. In: CONGRESO INTERNACIONAL DE MEDICINAS TRADICIONALES, 2., Lima, Pe, 1988. Resumenes, Área de Farmacognosia. Lima, Pe: Instituto de Fitoterapia Americano, 1988. p.109-113.

SCHULTES, R. E. Indícios da riqueza etnofarmacológica do noroeste da Amazônia. Acta Amazônica, v.91, n.1, p.209-215, 1979.

SCHULTES, R. E. Members of Euphorbiaceae in primitive and advanced societies. Botanical Journal of the Linnean Society, v.94, n.1/2, p.79-95, 1997.

SECCO, R. Notas sobre a primeira ocorrência de Croton urucurana Baill. (Sangrad'água) na Amazônia Brasileira, Belém, Pará. Boletim do Museu Paraense Emílio Goeldi, v.18, n.1, p.195-201, 2002.

SENATORE, A.; CATALDO, A.; IACCARINO, F. P.; ELBERTI, M. G. Phytochemical and biological study of Uncaria tomentosa. Bollettino Società Italiana Biologia Sperimentale, v.65, p.517-520, 1989.

SHENG, Y.; PERO, R. W.; AMIRI, A.; BRYNGELSSON, C. Induction of apoptosis and inhibition of proliferation in human tumor cells treated with extracts of Uncaria tomentosa. Anticancer Research, v.18, p.3363-3368, 1998. 
SHINEIDER, C.; BREITMAIER, E.; BAYMA, CARVALHO J. de; FRANCA, L.; KNEIFEL, H. Maravuic acid, a new seco-labdane diterpene from croton matourensis. Liebigs Annalen der Chemie, v.12, p.709-710, 1995.

SHULTES, E. F.; RAFFAUF, R. F. The healing forest medical and toxic plants of northwest Amazonia. Oregon, USA. Historical, Etno \& Economic. Botany Series, p.401-403, 1990.

SHUNKE, V.J. Cultivo de la "uña de gato". In: FORUM NACIONAL DE UÑA DE GATO, 1., Lima, Pe, 1998. Resumenes. Lima, Perú: Instituto de Desarrollo Rural Peruano, 1998. 30p.

SILVA, D. H.; ALAVARADO, D. R.; HIDALGO, H. J.; CERRUTTI, S. T.; GARCIA, R. J.; DÁVILA, M. W. MESTANZA, D. M.; RIOS, I. F.; NINA, C. E.; NONATO, L. R. Monografia de Uncaria tomentosa (Willd.) DC. Iquitos, Pe: Instituto Peruano de Seguridad Social/Instituto de Medicina Tradicional, 1998. 112p.

SILVA, M.; NOGUEIRA, P. E. Avaliação fitossociológica do estrato arbustivo herbáceo em cerrado stricto sensu após incêndio acidental, no Distrito Federal, Brasil. Boletim do Herbário Ezechias Paulo Heringer, v.4, p.65-79, 1999.

SILVA-NETO, S. J.; CALLADO, C.H. Anatomia do lenho de espécies do gênero Simira Aubl. (Rubiaceae, Rondeletieae) da Floresta Atlântica no Estado do Rio de Janeiro. In: CONGRESSO NACIONAL DE BOTÂNICA, 49., Salvador, Bahia-Brasil, 1998. Resumos. Salvador, Bahia: Sociedade Botânica do Brasil, 1998. p.38.

SMIT, E. H. Quinine is not what it use to be. Acta Leidensia, v.55, p.21-27, 1987.

SMITH, L. A.; DOWNS, R. J. Resumo preliminar das Euphorbiáceas de Santa Catarina. SELLOWIA, v.11, p.154-186, 1959.

SOSA, L.; MEDRANO, C. Evaluación de herbicidas para el control de malezas arbustivas en pastizales del Estado Zulia, Maracaibo-Venezuela. Revista de la Facultad de Agronomia de la Universidad de Zulia, v.9, n.4, p.199-212, 1992.

SOUZA-BRITO, A. R. M.; SOUZA-BRITO, A. A. Forty years of Brazilian medicinal plant research. Journal of Ethnopharmacology, v.39, n.1, p.53-67, 1993.

STELL, R. Flores para el Rey. Barcelona,España: Ed. Serbal. 1982. 347p.

STEYERMARK, J.A. Rubiaceae. In: LASER, T. Flora de Venezuela. Caracas, Ve: Instituto Botánico, Dirección de Recursos Naturales Renovables, Ministerio de Agricultura y Cria, Caracas, v.9, p.1-2070, 1974. 
STUPPNER, H.; STURM, S.; KONWALINKA, G. Capillary electrophoretic analysis of oxindole alkaloids from Uncaria tomentosa. Journal of Chromatography, v.609, p.375-380, 1992.

SYLVAIN G. R.; BREMER, B. Phylogeny and classification of Naucleeae (Rubiaceae) inferred from molecular (ITS, $r b c L$, and $t r n T-F$ ) and morphological data. American Journal of Botany, v. 89, n.7, p.1027-1041, 2002.

THE WORLD CONSERVATION UNION-IUCN, WORLD HEALTH ORGANIZATION-WHO, WORLD WIDE FUND FOR NATURE-WWFN. Guidelines for the Conservation of Medicinal Plants. Gland, Switzerland: IUNC, 1993. 1v.

TRATADO DE COOPERACION AMAZONICA. Plantas medicinales Amazónicas: realidades y perspectivas. Lima-Pe: Secretaria Pro-tempore, 1995. 270p.

TREASE, G.E.; W.C.EVANS. Tratado de Farmacognosia. 12.ed. México, DF. Nueva Editorial Interamericana, 1987. p.637-641.

UBILlAS, R.; JOLAD, R. C.; KERMNAN, M. R.; KING, S. R.; SESIN, D. F.; BARRET, M.; STODDART, C. A.; FLASTER, T.; KCO, J.; AYALA, F.; MEZA, E.; CCASTAÑEL, M.; MC'JEEKIN, D.; ROZHOV, E.; TEMPESTA, M.S.; BARNARD, D.; HUFFMAN, J.; SMEE, D.; SIDWELL, R.; JOIKE, K; BRAZIER, A.; SAFRIN, S.; ORLANDO, R.; KENNY, P. T.; BEROVA, N.; NEKANISHI, K. SP-303, na antiviral oligomeric oroanthocynidin from the latex of Croton lechleri (sangre de drago). Phytomedicine, v.1, n.2, p.77-106, 1994.

URRUNAGA, S.R. Uncaria tomentosa (uña de gato): un recurso fitogenético valioso del Perú. Cuzco, Peru. Centro de Plantas Medicinales-Universidad Nacional de San Antonio Abad del Cusco, 1994. 25p.

VAISBERG, A. J.; MILlA, M.; PLANAS, M. C.; CORDOVA, J. L.; AGUSTI, E. R.; FERREYRA, R.; MUSTIGA, M. C.; CARLIN, L.; HAMMOND, G. B.; DEAGUSTI, E. R. Taspine is the cicatrizant principle in sangre de grado extracted from Croton lechleri. Planta Medica, v.55, n.2, p.140-143, 1989.

VALLILO, M. I. Determinação de nutrientes inorgânicos nas folhas e ramos do Croton floribundus Spreng (Euphorbiaceae), por espectrometria de emissão atômica sequencial acoplada ao plasma de argônio induzido (ICP-AES), São Paulo-Brasil. Revista do Instituto Florestal, v.10, n.2, p.127-135, 1998.

VALliLO, M. I.; OLIVEIRA, E. Composição química do solo da Serra da Cantareira região da Pedra Grande, São Paulo-Brasil. Revista do Instituto Florestal, v.11, n.1, p.25-36, 1999. 
VAN-HARTEN, A. M. Quina Cinchona spp. Geotecnia de Cultivos Tropicales Perennes. AGT Editor, 1987. p 438-455.

VASQUEZ, R. Sistemática de las plantas medicinales de uso frecuente en el área de Iquitos. Iquitos, Peru. Folia Amazónica, v.4, n.1, p.61-75, 1992.

VASQUEZ, R. Flórula de las reservas biológicas de Iquitos-Perú. St. Louis Missouri, USA. Missouri Botanical Garden, 1997. 1046p.

VERPOORTE, R.; SCHRIPSEMA, J.; VAN-DER-LEER, T. Cinchona Alkaloid. Brossi. The Alkaloids, Chemistry and Pharmacology, v. 34, p.331-398, 1988.

VERVEEN, G. La Malaria. Hexágono-Roche, v. 2, n.3, p.11-16, 1984.

VILLACHICA, H.; LAZARTE, J.; CLAVO, M.; LESCANO, C.; ARROYO, M.; DIAZ, I. Productos amazónicos del Perú: palmito, camu-camu y uña de gato. Pucallpa, Peru. Consorcio Para el Desarrollo Sostenible de Ucayali-CODESU, 1998. 144p.

WAGNER, H.; KREUTZKAMP, B.; JURCIC, K. The alkaloids of Uncaria tomentosa and their phagocytosis stimulating action. Planta Medica, v.12, p.419-23, 1985.

WANDERLEY, P. C.; CHAVES, N.; BARBOSA, N. Chemical control of Croton campestris. In: CONGRESO ALAM Y SEMINARIO COMALFI, 6., Cali, Co, 1974. Resumenes. Santafé de Bogotá, Co: Asociacion Latinoamericana de MalezasSociedad Colombiana de Control de Malezas y Fisiologia Vegetal, 1974. 89p.

WANG, Z. Quantitative determination of the alkaloids of Uncaria rhynchophylla by calcium chromatography. ChineseTraditional and Herbal Drugs, v.20, p.11-20, 1989.

WARHURST, D.C. Cinchona alkaloids and malaria. Acta Leidensia, v.55, p.55-64, 1987.

WEBSTER, G. L. A provisional synopsis of the sections of the genus Croton (Euphorbiaceae). Taxon, v. 42, p.793-823, 1993.

WEBSter, G. L. Classification of the Euphorbiaceae. Annales. Missouri Botanical. Garden, v.81, p.3-32, 1994.

WEBSTER, G. L., DEL-ARCO-AGUILAR, M.J.; SMITH, B.A. Systematic distribution of foliar trichome types in Croton (Euphorbiaceae). Botanical Journal of the Linnean Society, v.121, p.41-57, 1996 
YEPEZ, A.; DE-UGAZ, O.; ALVAREZ, C.; DE-FEO, V.; AQUINO, R.; SIMONE, F.; PIZZA, C. Quinovic acid glycosides from Uncaria guianensis. Phytochemistry, v.30, p.1635-1637, 1991.

ZAVALA, A.; ZEVALLOS, P. P. Taxonomía, distribuición geográfica y status del Gênero Uncaria en el Perú.. Lima, Pe: Faculdad de Ciencias Forestales, Universidade Nacional Agraria La Molina, 1996. 103p.

ZEVALLOS, P. P. Taxonomía, distribución geográfica y status del gênero Cinchona en el Perú. Lima, Peru. Centro de Datos Para la Conservación, Universidade Nacional Agraria la Molina, 1989. 87p.

ZEVALLOS, P. P.; LOMBARDI, I.; BERNAL, Y. Agrotecnología para el cultivo de la uña de gato o bejuco de agua". In: MARTÍNEZ J. V.; BERNAL, H. J.; CÁCERES, A. Fundamentos de agrotecnología para el cultivo de plantas medicinais Iberoamericanas. Santafé de Bogotá, Co: Convenio Andrés Bello/Ciencia y Tecnología para el Desarrollo, 2000. p.463-492.

ZEVAllos, P. P.; ChAVESTA, C. M.; BUITRON, D. G.; TAKASHIBA, H. E. Determinação de contenidos oxindolícos de espécies del género Uncaria Schreb. "uña de gato" a través de la correlación de características foliares y anatómicas de la madera en tres localidades de la amazonia peruana. In: CONGRESO LATINOAMERICANO DE BOTÁNICA, 8., Cartagena de Indias, Co, 2002 Resúmenes del VIII-CLB. Santafé de Bogotá, Co: ALB/ACB/ACH/ICN, 2002. p.350. 